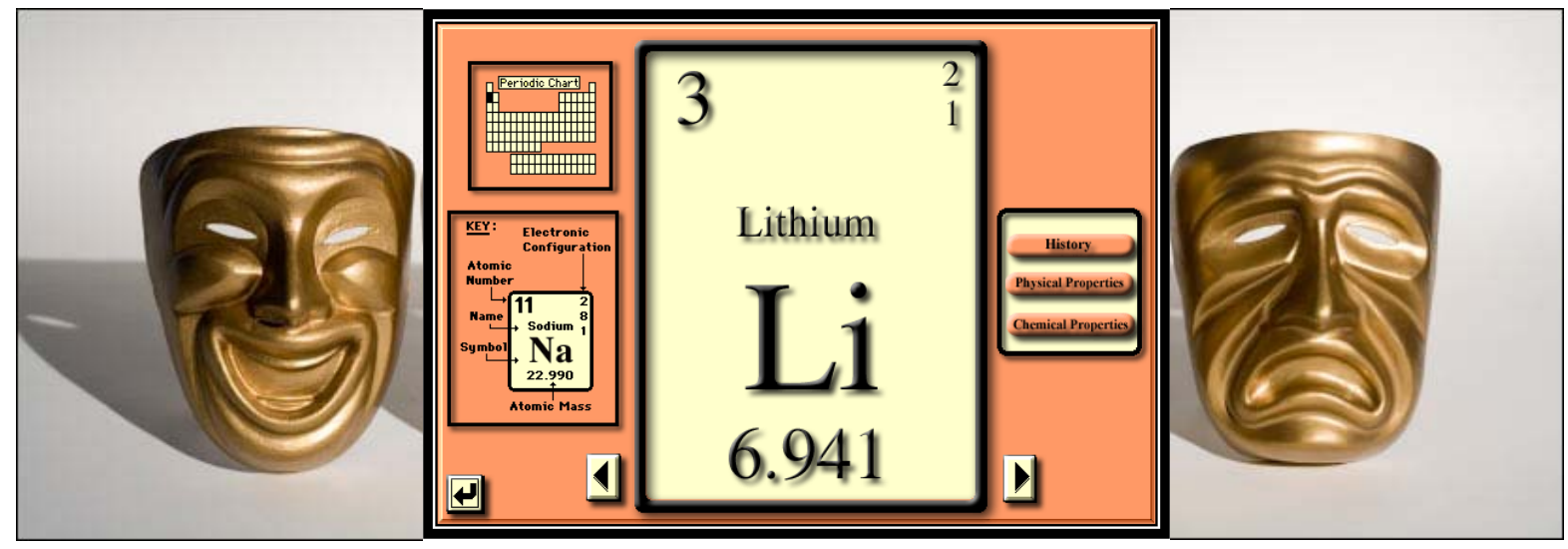

\title{
APE MINERALE LITINIFERE
}

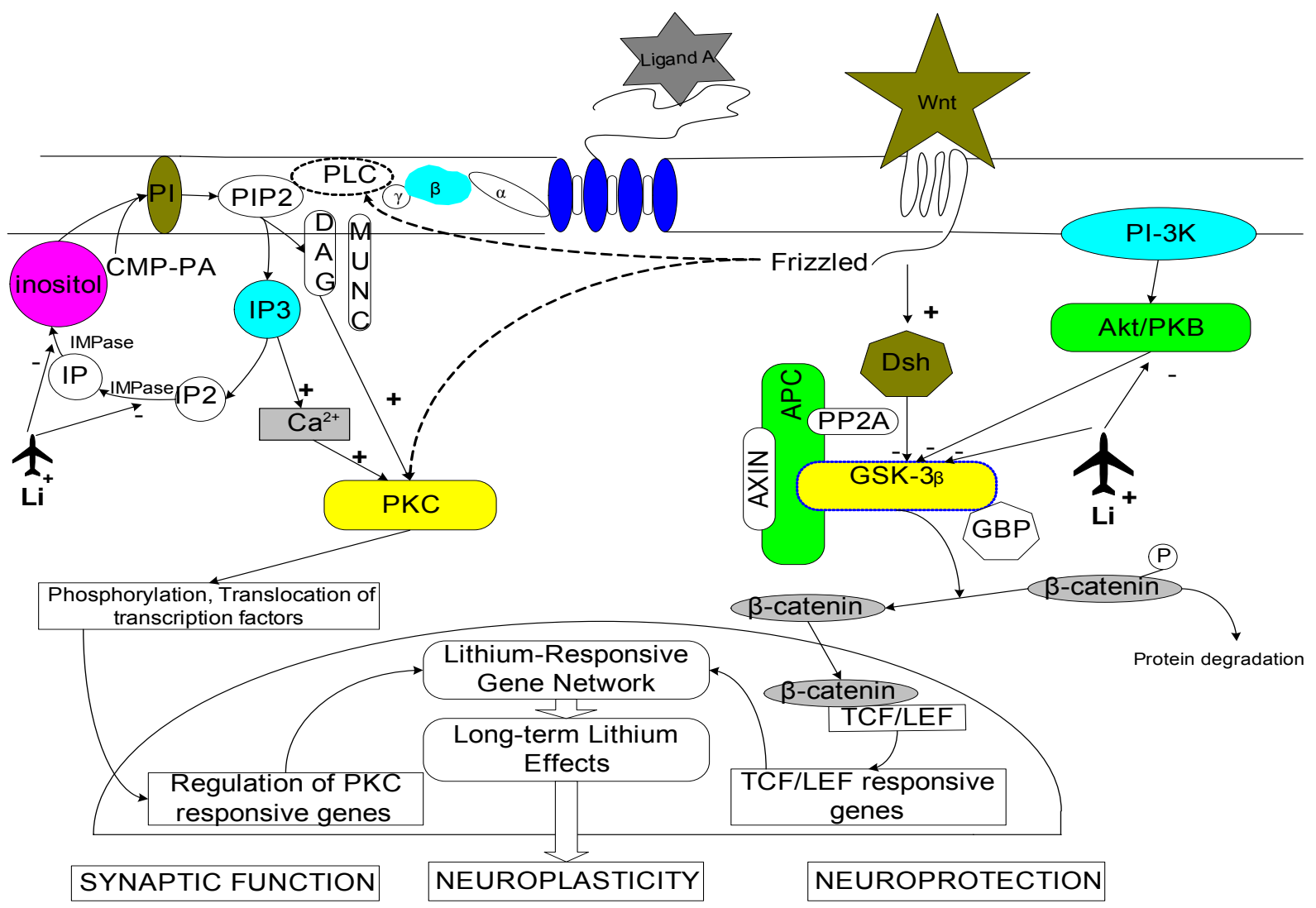

Editura Balneara

- 2011 - 


\section{Descrierea CIP a Bibliotecii Naționale a României MUNTEANU, CONSTANTIN}

Ape minerale litinifere / Constantin Munteanu, Diana Munteanu. Bucureşti : Editura Balneară, 2011

ISBN 978-606-92826-0-1

I. Munteanu, Diana

553.7

615.327

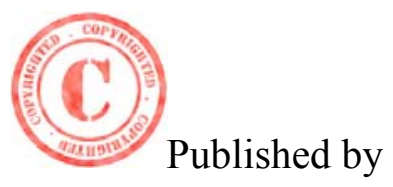

Editura Balnearã - http://editura.pluto.ro

Laborator Culturi Celulare - http://cell-culture.xhost.ro/

E-mail: culturi@gmail.com

B-dul Ion Mihalache, 11A, Sector 1, Bucharest, Romania

ISBN: 978-606-92826-0-1 


\section{APE MINERALE LITINIFERE}

\section{Editura Balneara}

$$
\text { - } 2011 \text { - }
$$





\section{CUPRINS}

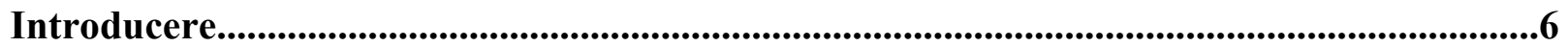

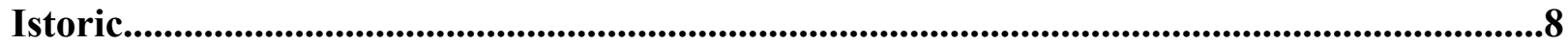

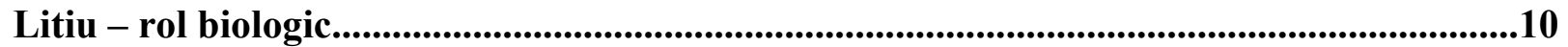

Proprietãţile fizice şi chimice ale ionilor de litiu..............................................................17

Litiu ca element secundar în organism...............................................................................21

Transportul ionilor de litiu prin membrana celularã.....................................................24

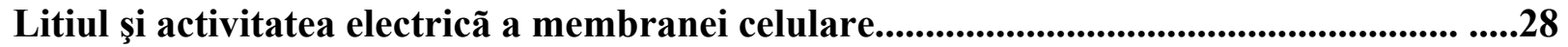

Litiul şi ciclul fosfo-inositidic.........................................................................................30

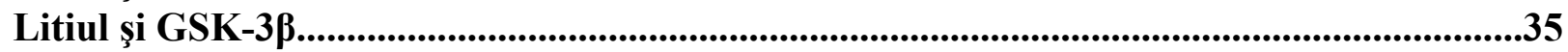

Acțiunea litiului asupra altor cãi de semnalizare...........................................................38

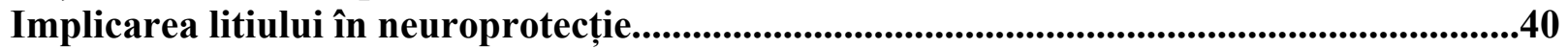

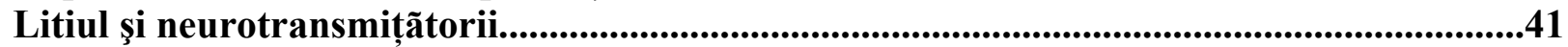

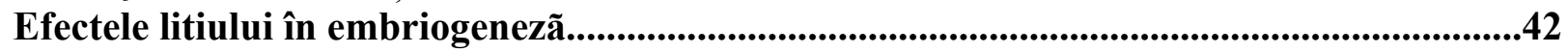

Influența litiului asupra ritmului circadian..........................................................................43

Litiul şi expresia genicã..........................................................................................................47

Proprietãți clinice ale litiului....................................................................................51

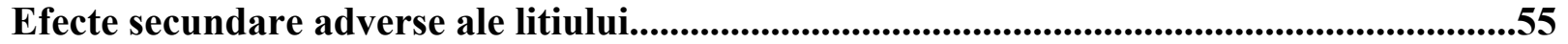

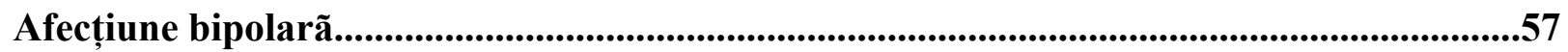

Neurobiologia afectiunii bipolare....................................................................................................63

Maniaco-depresia şi semnalizarea intracelularã...................................................................71

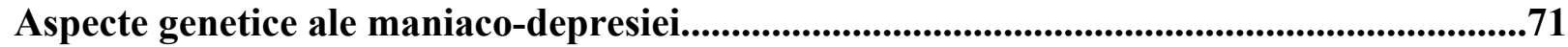

Ritmurile circadiene şi tulburarea bipolarã...............................................................75

Modelarea matematicã a psihozei bipolare II printr-un oscilator armonic.........................77

Diagnostic...................................................................................................................................................79

Evoluția clinicã a maniaco-depresiei.............................................................................................81

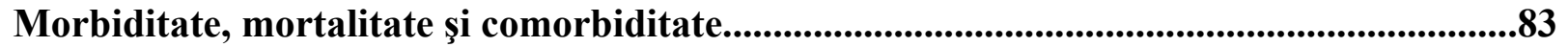

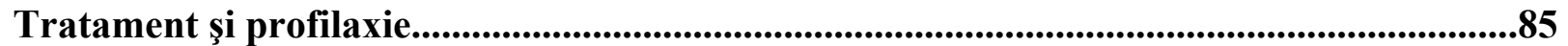

Efectele litiului asupra morfologie culturilor de celule gliale............................................93

Efectele apei minerale MARIA asupra morfologie culturilor de celule gliale....................105

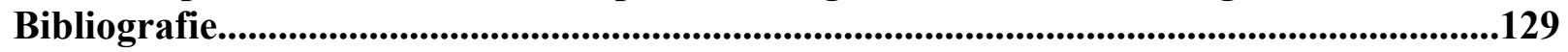




\section{Introducere}

România se înscrie printre tãrile europene cu un fond balnear remarcabil, având şansa ca o treime din apele termale şi minerale de pe continent sã se afle în ţara noastrã. Aceastã valoare este subliniatã de complexitatea factorilor naturali, respectiv regãsirea în aceeaşi staţiune a factorilor principali de mediu, alãturi de o gamã largã de substanțe minerale de curã, cu efecte polifactoriale benefice, care acoperã întreaga gamã a profilurilor de tratament balnear.

Resursele balneare sunt reprezentate în primul rând de substanțe minerale terapeutice, care prin proprietãțile lor fizico-chimice rãspund necesitãţilor profilactice şi medicale de menţinere, consolidare şi refacere a stãrii de sãnãtate, a capacitãţii de muncã şi de reconfortare fizicã şi psihicã a individului.

Cercetãrile hidrologice au arãtat cã subsolul României are o varietate de resurse balneare situate în interiorul sau la suprafaţa scoarței terestre. Apele minerale sunt rãspândite pe mai mult de $20 \%$ din suprafaţa țãrii la diferite adâncimi, având numeroase proprietãți fizico-chimice şi terapeutice în funcție de geneza lor.

Sunt considerate ape minerale terapeutice, apele ivite la suprafaţã dintr-o sursã naturalã sau aduse la zi prin foraje şi ale cãror caracteristici fizico-chimice pot exercita efecte farmaco-dinamice cu rol terapeutic. Apele minerale sunt cele care au un conținut variabil de sãruri, gaze, substanțe minerale, elemente radioactive, care le conferã proprietãți terapeutice. În trecut, denumirea de apã mineralã se atribuia tuturor apelor subterane sau superficiale care puteau fi utilizate în scopuri terapeutice. În ultimii ani, apelor minerale destinate scopurilor terapeutice li s-a dat denumirea de ape curative.

Litiul stârneşte un deosebit interes ştiinţific pentru cã, deşi are o structurã atât de simplã, o chimie uşor de analizat şi proprietãţi fizice bine stabilite, pleiada de efecte asupra sistemelor biologice prin influențarea numeroaselor procese celulare şi moleculare şi mecanismul sãu de acțiune încã neelucidat generează un mister pe care ştiința modernă încearcă să îl descifreze.

Sãrurile de litiu şi-au dovedit eficiența în tratamentul tulburãrii bipolare, formal cunoscutã ca boala maniaco-depresivã. Aşa cum o aratã şi numele, persoanele care suferã de tulburare bipolarã traverseazã schimbãri afective severe, de la fericire maximã la o depresie extremã. Între 0.4 şi $1.6 \%$ din populaţie suferã de aceastã condiție psihiatricã.

Utilizarea litiului în medicinã cunoşte un semnificativ succes în câmpul farmacologiei inorganice şi prezintã un interes particular, de vreme ce litiul este cel mai uşor element solid a cãrui chimie este relativ simplã. Se acceptã cã orice ar determina litiul în celulã, acțiunea lui ținteşte procese fundamentale din viața celularã.

Cercetarea intervenției litiului asupra sistemului celular reprezintã o paralelã accesibilã pentru investigarea interacțiunilor moleculare ale unor medicamente mult mai complexe cu receptorii lor. 
Orice ar face litiul, el reuşeşte mai ales datoritã încãrcãturii sale cationice înalte, cu o largã razã de hidratare şi proprietãţi chimice asemãnãtoare magneziului.

La nivelul sistemului nervos central s-a raportat cã litiul conferã protecție celulelor nervoase la acțiunea unei varietãți de injurii. Litiul induce remodelarea sinapticã neuronalã, ceea ce ar putea conta pentru efectele clinice pozitive în tratamentul tulburãrilor afective.

Studii in vivo şi in vitro au demonstrat cã litiul exercita multiple efecte asupra semnalizãrii receptor mediate prin neurotransmițãtori, transportului ionic, cascadelor de semnalizare, reglãrii hormonale, ritmicitãții circadiane şi expresiei genice (Cyrus et all, 2006). Din pãcate, mecanismele moleculare responsabile pentru toate aceste efecte sunt încã un subiect de dezbatere. Mecanismele biochimice ale acțiunii litiului apar ca fiind multifactoriale şi inter-corelate cu funcționarea mai multor enzime, hormoni şi vitamine, ca şi cu factori de creştere şi transformare (Schrauzer, 2002).

Efectele acute ale litiului sunt mediate prin inhibarea unor enzime specifice implicate în douã cãi distincte dar interactive de semnalizare - calea protein kinazei C şi cascada glicogen-sintetaz kinazei $3 \beta$ - care converg la nivelul transcripției genice.

Expresia unor gene, inclusiv factori transcripționali, este semnificativ schimbatã de administrarea cronicã a litiului. Tratamentul cronic cu litiu creşte expresia proteinei neuroprotective $\mathrm{Bcl} 2$, determinând posibilitatea interesantã ca unele efecte ale litiului sã fie mediate prin efecte neurotrofice/neuroprotective (Ikonomov şi Manji, 1999).

În centrul României, în județul omonim, aşezat în depresiunea Braşovului, la poalele vestice ale munţilor Vrancei, la o altitudine ce variazã între 550 şi $600 \mathrm{~m}$, la 31 Km est faţã de municipiul Sfântu Gheorghe, se aflã oraşul Covasna - un important centru pentru îmbutelierea apelor minerale.

Apa mineralã medicinalã cunoscutã sub denumirea Maria este îmbuteliatã în staţiunea balneoclimatericã Malnaş-Bãi. Staţiunea Malnaş-Bãi este situatã în defileul care desparte Munții Bodoc de Munții Baraolt, la cca $22 \mathrm{Km}$ de Sf. Gheorghe. Climat fãrã amplitudini termice mari, temperatura medie anualã este de $7^{0} \mathrm{C}$ iar cantitatea medie anualã de precipitaţii de $600 \mathrm{~mm}$. Formarea staţiunii dateazã încã din anul 1759, iar dupa 1865 renumele sãu ajunge si peste hotare.

Apa mineralã Maria este o apã bicarbonatatã, cloruratã, sodicã, carbogazoasã, hipotonã, utilizatã pentru curã internã şi îmbuteliere.

Apa mineralã medicinalã Maria este îmbuteliatã încã din anul 1904, de când a fost recomandatã la tratarea diferitelor boli digestive, cum ar fi afecţiuni ale tubului digestiv (gastrite cronice hiperacide, ulcere gastrice şi duodenale, colite cronice, constipația cronicã), acțiuni hepatobiliare (dischinezia biliarã, hepatita cronicã, pancreatita cronicã, colecistita cronicã necalculoasã sau calculoasã), boli asociate: nevrozã astenicã, migrenã, tulburãri afective.

Apa medicinalã Maria de la Malnaş-Bãi, cu un conținut de $8 \mathrm{mg}$ litiu la litru a fost utlizatã în cercetãri clinice şi experimentale în tratamentul migrenei şi tulburãrilor afective, afecțiuni care nu au intrat în spectrul terapeutic al apei în trecut. 


\section{Istoric}

În 1817, August Arfvedson a descoperit litiul, lucrând în laboratorul sãu din Suedia. Berzelius a fost cel care a dat numele elementului litiu (gr. lithos - piatrã).

Observația cã litiul poate fi gãsit în apele minerale utilizate în însãnãtoşire a dus la ideea cã litiul ar putea fi responsabil de vindecarea celor ce utilizau aceste ape (Fieve, 1984). Rãspândirea largã şi comercializarea haoticã a sãrurilor de litiu în poțiuni şi ape minerale, mai întotdeauna la concentrații neadecvate, pentru o varietate de boli, au contribuit la deziluzia generalã asupra ipotezelor medicale empirice privind rolul terapeutic al litiului. Utilizarea sãrurilor de litiu ca substitut al sodiului pentru tratamentul diatezei cronice cardiace şi renale a avut ca rezultat o creştere a incidenței morbiditãții şi mortalitâții direct legatã de toxicitatea litiului. Abia dupã publicarea rezultatelor lui John Cade, litiului i s-a reconferit statutul de agent farmacoterapeutic (Lenox şi Watson, 1994).

Litiul a fost utilizat în tratamentul depresiei în a doua jumãtate a secolului al XIX-lea, deşi ipoteza pe baza cãreia a fost stabilitã aceastã valențã terapeuticã a fost de fapt incorectã. Succesul terapeutic a fost raportat într-un numãr de cazuri izolate. Efectul anti-maniac al litiului a fost descoperit în 1949 şi confirmat printr-un studiu placebo-controlat din 1954.

Litiul există în țesuturile biologice, în alimente şi în apa potabilă. Apele naturale pot sã conținã concentrații de peste $3 \mathrm{mg}$ la litru de litiu, alãturi de ioni ai altor metale, caz în care sunt numite ape minerale litinifere (Birch, 1999). Cea mai mare cantitate de litiu se foloseşte la producerea aliajelor metalice uşoare, sticlei, unsorilor lubrefiante şi bateriilor electrice. Mai puțin de $1 \%$ se utilizeazã medical.

Sărurile de litiu au fost folosite prima dată terapeutic în 1850, în ameliorarea simptomelor gutei, reumatismului, litiazei renale. În 1949, Cade are meritul de a fi descoperit efectul sedativ al sărurilor de litiu în starea de agitație maniacală, dar terapia este însoțită de frecvente cazuri de intoxicație. În perioada anilor $60 \mathrm{~s}$-a arãtat cã litiul previne recurențele atât maniacale cât şi depresive. Acest efect profilactic a fost mai întâi demonstrat într-un studiu deschis, utilizând metoda „oglinzii”, şi mai apoi (dupã 1970) confirmat printr-un numãr de studii controlate placebo - dublu orb. Profilaxia litiului a fost similar eficace la pacienții bipolari şi unipolari. Ĩn 1967, se reuşeşte determinarea valorii terapeutice a litemiei, situatã în intervalul: $0,5-1,5 \mathrm{mEq} / 1$.

Un eveniment istoric important legat de siguranța şi optimizarea profilaxiei litiului a avut loc în anii '70. Au apãrut cercetãri care indicau cã utilizarea îndelungatã a litiului poate determina îmbolnãvirea rinichilor. Prin eforturi comune exemplare a mai multor cercetãtori a fost posibilã retractarea celor mai multe dintre rapoartele alarmante. Din anii '70, cercetãtorii şi clinicienii au recomandat niveluri serice de litiu uşor mai scãzute decât cele implicate în efectele adverse. 


\section{THE MEDICAL JOURNAL OF AUSTRALIA.}

LITHIUM SALTS IN THE TREATMENT

OF PSYCHOTIC EXCITEMENT.

By JoH: F. J. CADE, M.D.,

Senior Medical Officer, Victorian Department of Mental Hygiene.

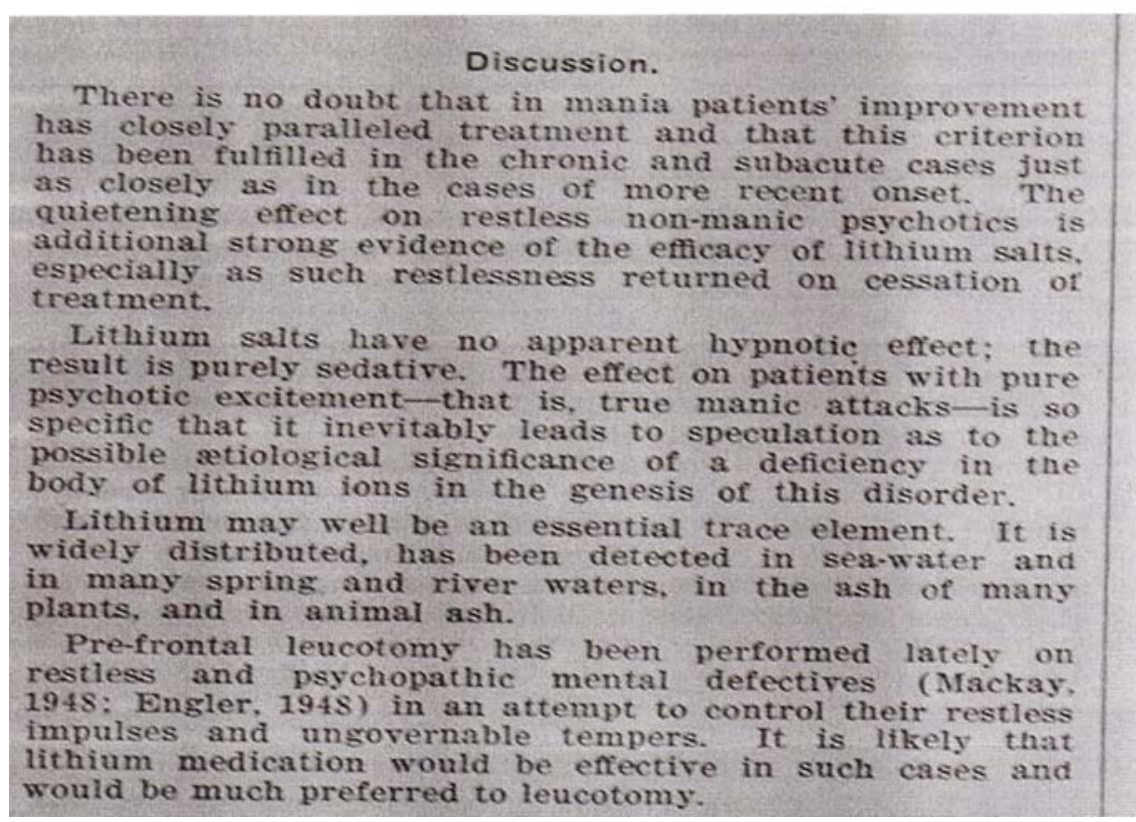

Figura 1 - Ilustrația faimosului articol al Dr. John Cade: unul dintre cele mai citate articole publicate vreodatã în Medical Journal of Australia

Un studiu internațional realizat prin participarea mai multor centre de cercetare a stabilit cã mortalitatea şi rata de suicid au fost semnificativ diminuate de tratamentul pe termen lung cu litiu, efecte ce nu au fost egalate pânã acum de nici un alt tratament profilactic.

În 1971, mai mulți cercetãtori au raportat reducerea nivelului de inozitol în creier la şobolani trataţi cu litiu. În prezent, ionii de litiu sunt încã una dintre puținele modalitãți farmacologice utilizabile pentru investigarea cãilor metabolice implicate în ciclul fosfatidilinozitidic, iar capacitatea litiului de a inhiba myo-inositol monofosfataza la concentrații relevante terapeutic $(0.5-1.5 \mathrm{mM})$ este acum verificatã. 


\section{Litiu - rol biologic}

Litiul are cea mai simplã structurã dintre toți agenții terapeutici, iar proprietãțile sale bioactive sunt cunoscute de peste un secol. Litiul este foarte eficient în tratamentul tulburãrilor bipolare şi are de asemenea multiple efecte asupra dezvoltãrii embrionare, sintezei glicogenului, hematopoiezei şi a altor procese.

În sistemul nervos central şi în țesuturile periferice, acțiunea litiului poate fi mediatã sau determinatã prin inhibarea inositol-monofosfatazei sau a GSK-3 $\beta$, dar cu siguranțã imaginea este cu mult mai complexã. Provocarea este de a determina ținta responsabilã pentru un anumit rãspuns celular la acțiunea litiului. Aceste ținte potențiale sunt larg rãspândite, necesitã un ion metalic pentru catalizã şi sunt inhibate de litiu într-o manierã necompetitivã, probabil prin înlocuirea cationului bivalent.

Comparația dintre efectele litiului cu eliminarea genicã a unor molecule țintã a ajutat la validarea acestor ținte, iar utilizarea inhibitorilor alternativi ale unor anumite ținte pot aduce un suport puternic pentru sau împotriva unor propuse mecanisme de acțiune a litiului (Phiel şi Klein, 2001)

Pentru a valida ținta molecularã, trebuiesc îndeplinite mai multe criterii. Efectele biochimice trebuie sã se producã la valori de concentrație relevante terapeutic, dupã administrare cronicã, şi ele trebuie sã afecteze sisteme neuronale care sunt posibil implicate în reglarea stãrii afective (Coyle şi Manji, 2002).

Cãutarea țintelor moleculare ale administrãrii litiului este similarã cu încercarea de a identifica genele responsabile pentru caractere complexe comportamentale şi fiziologice, precum obezitatea, hipertensiunea, ritmurile circadiene.

În toate aceste situaţii rolul unei proteine candidat identificate este dovedit de capacitatea de a corecta fenotipul anormal. De aceea este critic sã se reținã cã analiza bazelor moleculare ale acțiunii litiului este plinã de sens numai în condițiile unui fenotip clar indus de litiu (Ikonomov şi Manji, 1999).

Cele mai multe dintre mecanismele propuse pentru acțiunea la nivel celular a litiului au sugerat un efect inhibitor asupra unor componente ale mai multor cãi de semnalizare, cum ar fi formarea AMP, formarea ciclic GMP, proteinelor G, sau metabolismului inozitol-fosfatului (Berridge et all, 1989).

Glicogen - sintetaz kinaza $3 \beta$ (GSK-3 $\beta$ ) este o proteinã a cãrei activitate in vitro s-a raportat a fi inhibatã de ionii de litiu, iar aceastã acțiune pare sã conteze pentru schimbãrile în dezvoltare cauzate de litiu la Dyctiostelium şi Xenopus.

Myoinositol monofosfataza şi GSK-3 $\beta$ necesitã cataliza din partea unor ioni metalici şi sunt inhibate de litiu într-o manierã necompetitivã, cel mai probabil prin înlocuirea ionului metalic de la sistemul catalitic.

S-a arãtat cã litiul este un inhibitor a numeroase fosfomonoesteraze similare structural, magneziu-dependente, la valori de concentraţie cuprinse în scala relevantã terapeutic (0.8-1.2 mM). Studii biochimice şi genetice au identificat inozitol polifosfataze ca ținte suplimentare pentru acțiunea litiului (Lenox et all, 2000). 
Observații de geneticã molecularã în sisteme model subliniazã $\operatorname{Ins}(1,4,5) \mathrm{P}_{3}$ ca țintã clinic relevantã a litiului (Williams et all, 2000). Litiul inhibã enzimele inozitolmonofosfatazice şi prin urmare obstrucționeazã degradarea enzimaticã a inozitolfosfatului $\mathrm{IP}_{3}$ în ciclul fosfatidil-inozitolic. Aceastã inhibare poate rezulta în reducerea disponibilitãţilor de mesageri secundari $\mathrm{IP}_{3}$ şi DAG, care sunt derivaţi ai ciclului PIP.

Proteinele $\mathrm{G}$ sunt o familie generalã de proteine care îndeplinesc rolul critic de transducere a informaţiei la nivelul membranei plasmatice, cuplând numeroşi receptori la efectorii specifici. Proteinele $G$ sunt implicate în cãi de reglare a unor funcții vegetative diverse, cum ar fi dispoziția, apetitul şi starea de veghe, iar prin extrapolare, în mecanismele de acțiune ale medicamentelor de stabilizare a stãrii dispoziţionale.

Prima evidențã directã cã proteinele $\mathrm{G}$ ar putea fi ținte ale acțiunii litiului a fost oferitã de Avissar şi colegii sãi, care au raportat cã litiul eliminã semnificativ creşterile induse de isoproterenol - şi chrbachol - în legarea $\mathrm{H}^{3}$-GTP la variate proteine $\mathrm{G}$ în membranele cerebrale corticale la şobolan (Manji et all, 1995).

Administrarea cronicã a litiului scade turnover-ul acidului arahidonic (AA) în mai multe fosfolipide din creier ceea ce se coreleazã cu o scãdere semnificativã a activitãţii fosfolipazei $\mathrm{A}_{2}\left(\mathrm{PLA}_{2}\right)$. Prin urmare, un efect terapeutic major al litiului este

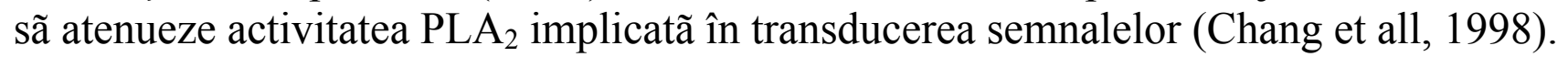

S-a arãtat cã tratamentul cronic la şobolani (cu niveluri serice relevante terapeutic de aproape $1 \mathrm{mM}$ ) creşte nivelul ARNm şi al proteinei pentru formele de calmodulinã- senzitivã (tip I) şi calmodulinã - insenzitivã (tip II) de adenilat ciclazã şi scade nivelul de ARNm şi cel proteic al subunitãţilor inhibitorii $G_{i \alpha 1}$ şi $G_{i \alpha 2}$ ale proteinelor $\mathrm{G}$. Reglarea de cãtre litiu a adenilat ciclazei şi a subunitãților $\mathrm{G}_{\mathrm{i} \alpha}$ nu a fost demonstratã ca rãspuns la tratamente de termen scurt sau ca rãspuns la tratamente cronice cu doze foarte mici de litiu (Collin et all, 1991).

O țintã alternativã a litiului este sugeratã de similaritatea dintre acțiunea litiului şi efectul ectopic al expresiei genelor wnt la embrionii de Xenopus (Klein et all, 1995).

Litiul mimeazã semnalizarea Wnt prin inhibarea GSK-3 $\beta$ atât in vivo cât şi in vitro. Aceasta sugereazã cã efectele în dezvoltare ale litiului, întotdeauna observate, care nu se pot explica prin inhibarea inozitol monofosfatazei, ar putea fi de fapt determinate de inhibarea GSK-3 $\beta$ (Lenox et all, 2003).

Prin douã acțiuni pe deplin separate, inhibarea semnalizãrii fosfoinozitidice şi inhibarea GSK-3 $\beta$, litiul este capabil simultan sã scadã nivelul înalt al transcripției factorului AP1 (activator protein 1) - stimul indus al legãrii la ADN, şi respectiv sã creascã activitatea bazalã a legãrii AP1 la ADN.

Acestã acțiune bimodalã a litiului seteazã procesul astfel încât activitatea bazalã a AP1 sã nu fie foarte scãzutã, dar nici sã nu creascã exagerat dupã stimulare, protejând astfel celula fațã de o creştere extremã a activitãtii factorului AP1, ceea ce conferã în final o influențã stabilizatoare asupra fluctuațiilor de semnalizare (Jope, 1999). 
De vreme ce GSK-3 $\beta$ joacã un rol critic în sistemul nervos central prin reglarea a numeroase sisteme şi prin controlul a numeroase procese citoscheletale, ca de asemenea prin rolul asupra mai multor evenimente nucleare de termen lung, şi pentru cã este o țintã comunã atât pentru litiu cât şi pentru valproat, inhibarea sa necesitã viitoare cercetãri (Manji et all, 2001),

Existã argumente pentru efectul litiului asupra expresiei unui numãr de gene la nivel nervos, inclusiv legarea la ADN şi transactivarea factorului transcripţional AP1, precum şi a unor factori genetici pro- şi antiapoptotici din calea Akt/PKB.

Cãile de semnalizare prin protein kinaza $\mathrm{C}$ şi prin GSK-3 $\beta$ sunt perturbate de administrarea cronicã a litiului la concentrații relevante din punct de vedere terapeutic şi au fost implicate în modularea funcțiilor sinaptice la nivelul terminaţiilor nervoase.

Corelarea genelor litiu-responsive într-o rețea poate furniza o strategie de identificare a semnãturii exresiei genice asupra unor pattern-uri care diferențiazã acțiunile terapeutice de cele non-terapeutice ale litiului (Lenox et all, 2003).

Numeroase acţiuni ale litiului sunt esenţiale pentru efectul sãu terapeutic, şi aceste acțiuni complexe stabilizeazã activitãțile neuronale, susțin plasticitatea neuronilor şi asigurã neuroprotecţia. Modularea neurotransmiţãtorilor cu ajutorul litiului regleazã probabil balanţa dintre activitãțile excitatorii şi inhibitorii, iar scãderea activitãții glutamatergice poate contribui la neuroprotecție.

Litiul moduleazã semnale cu impact asupra citoscheletului, un sistem dinamic ce contribuie la plasticitatea neuronalã, la nivele multiple, incluzând GSK-3 $\beta$, kinaza dependentã de AMPc şi PKC ce pot fi esenţiale pentru plasticitatea neuronilor implicați în stabilizarea şi recuperarea comportamentalã.

Litiul ajusteazã activitãţile de semnalizare reglând mesageri secundari, factori de transcripție şi expresia genelor. Consecinţa acestor efecte este limitarea dimensiunilor fluctuațiilor în activitate, contribuind la o influențã stabilizatoare indusã de litiu, iar efectele neuroprotective pot deriva din modularea expresiei genelor (Jope, 1999).

Efectele biologice ale litiului pot fi împãrțite în: efecte pe termen scurt (manifestate la scurt timp dupã aplicare şi mediate prin complexul celular disponibil) şi efecte pe termen lung (presupuse a se baza pe schimbãrile selective în expresia genelor şi care apar dupã o perioadã de întârziere de la câteva zile la sãptãmâni).

Multe dintre efectele litiului pe termen scurt par a fi specifice celulelor sau țesuturilor. Exemple de efecte stimulatorii pe termen scurt includ secreția de corticotropinã indusã de litiu a celulelor pituitare anterioare de şobolan şi eliberarea masivã de glutamat la porțiuni din creier tratate cu litiu. Efectele inhibitorii ale tratamentului pe termen scurt cu litiu sunt dovedite de secreția de aldosteron indusã de angiotensina II a celulelor glomerulare adrenale şi coeficientul de relaxare ce urmeazã inducerii colinergice a contracției muşchiului neted.

Un grup separat de efecte sunt cele teratogene ale expunerii la litiu pe termen scurt, în dezvoltarea timpurie. Astfel, un tratament scurt la un stadiu de 32-64 de celule la un embrion Xenopus duce la un embrion cu douã structuri dorsale, un efect numit 
„dorsalizare”. Efectele profunde de dezvoltare ale litiului sunt de asemenea susținute cu studii realizate pe ariciul de mare, zebrafish (Demio reria) şi Dictyostelium. Trebuie menţionat cã multe dintre aceste efecte de dezvoltare sunt observate la concentrații care sunt cu mult mai mari decât cele terapeutice.

Printre schimbãrile fenotipice pe termen lung se pot menționa alterãri induse de litiu asupra ritmului circadian şi desigur schimbãri de comportament la pacienţii cu afecțiuni bipolare apãrute dupã 2-3 zile sau câteva sãptãmâni.

Tratamentul cronic cu litiu la şobolanii de laborator duce la un deficit persistent de execuție la unele teste de comportament (evitarea activã şi vizualã a labirintului), luând în considerare cã deficitul la o sarcinã cu memorie spaţialã este trecãtor. Un deficit trecãtor similar este observat în abilitatea acetilcolinei de a potenţa rãspunsuri ale NMDA în neuronii hipocampici. În plus tratamentul cronic cu litiu a fost consemnat ca inhibitor al atacului la modelele stimulate pentru epilepsie la şobolani, în ciuda agoniştilor colinergici.

Recent, administrarea cronicã de litiu a arãtat efecte neuroprotective împotriva a numeroase injurii atât in vivo cât şi in vitro, efecte care sunt probabil mediate de creșterea litiului în expresia proteinei neuroprotective Bc12.

În sfârşit, o importantã consideraţie este aceea cã, pe lângã efectele benefice asupra comportamentului, tratamentul cronic cu litiu este asociat cu multe efecte secundare cum ar fi poliurie, polidipsie, şi deteriorarea clinicã a funcţiei tiroidiene.

Se crede cã aceste efecte secundare obişnuite sunt datorate, cel puţin în parte, inhibãrii adenilat ciclazei sensibilã la vasopresinã (şi tirotropinã) indusã de litiu, în tubii distali renali şi respectiv glanda tiroidã. În plus, toxicitatea litiului la drojdii este asociatã cu inhibarea enzimelor procesate de ARN.

Mai mult, statusul asemãnãtor diabetului zaharat ce însoțeşte administrarea cronicã de litiu la şobolani creşte nivelele de ARNm pentru vasopresinã în nucleii hipotalamici paraventricular şi supraoptic.

Similar, hormonii tiroidieni sunt cunoscuți ca resopnsabili de o multitudine de schimbãri în expresia genelor în SNC.

Aceste observaţii ilustreazã multiplele cauze ale reglãrii diferențiale ale expresiei genelor ce trebuie luate atent în considerare în cãutarea genelor țintã relevante terapeutic pentru litiu (Ikonomov şi Manji, 1999)

Dincolo de proprietãţile sale afectiv-stabilizatoare, litiul prezintã intervenții în dezvoltare, metabolism şi hematopoiezã la concentraţii milimolare.

Astfel, s-a dovedit experimental cã litiul afecteazã profund dezvoltarea unor organisme inferioare cum ar fi Dyctyostelium şi Xenopus, dar, surprinzãtor, puţine efecte teratogene au fost raportate la om.

Cel mai evident efect metabolic atribuit litiului este stimularea sintezei glicogenului, mimând astfel acțiunea insulinei. Privind hematopoieza, la om s-a raportat o creştere a numãrului de granulocite circulante - celule stem hematopoietice sub acțiunea litiului. 
În ultimii ani, o noua etapã de interes asupra litiului a început prin descoperirea efectelor care nu au nici o legaturã cu utilizãrile sale psihiatrice. Multe din aceste efecte sunt determinate de modificãrile pe care litiul le induce asupra proceselor hematopoietice, în principal stimularea de cãtre litiu a leukocitozei care se produce datoritã creșterii mielopoiezei şi schimbãrilor la nivelul leucocitelor polimorfonucleare periferice. Factorii de stimulare ai coloniilor din mãduva osoasã înregistreazã nivele crescute în prezența litiului. Inițial, acest efect a fost exploatat pentru tratamentul supresiei hematopoietice indusã de medicamente, de exemplu în chimioterapia cancerelor; dupã transplantul de mãduvã osoasã, sau dupã disfuncțiile induse de iradiere. Metalul poate avea de asemenea efecte asupra rãspunsurilor imune la un numãr de provocãri antigenice ale organismului. S-a arãtat de altfel cã litiul poate influența o serie de citokine care regleazã diferențierea celularã, nu numai în cazul celulelor formatoare din sânge, dar şi în cazul multor altor tipuri de celule.

Litiul stimuleazã direct expresia genicã prin calea factorului transcripțional AP-1 şi este posibil ca aceasta sã explice diversitatea efectelor sale asupra diferitelor sisteme. Litiul singur are efecte antitumorale stimulând eliberarea factorului de necrozã tumoralã (TNF) prin stimularea macrofagelor. Potențialul litiului de a modifica activarea sau dezactivarea unor citokine cu rol asupra celulelor tumorale a primit de asemenea o atenție deosebitã.

Litiul este de asemenea capabil sã ținteascã monocitele umane, determinându-le sã elibereze TNF- $\alpha$. Monocitele de la pacienții cu cancer de sân tratate cu LiCl elibereazã cantitãţi mai mici de TNF- $\alpha$ decât cele de la pacienții sãnãtoşi. Producția de IL6 la monocitele tratate a fost, in tot cazul, neschimbatã, şi se sugereazã cã este un factor care poate modera efectele litiului.

Sãrurile de litiu ale acidului gamma linolenic (LiGLA) au fost promovate pentru efectele de reducere a progresiei unei varietãți de cancere, urmatã de demonstrarea citotoxicitãţii acidului gamma-linolenic şi a sãrurilor sale, in vitro, fațã de o gamã largã de celule maligne. Existã evidențe cã LiGLA are un efect antitumoral substanțial în cazul unui spectru de cancere. Se poate ca citotoxicitatea sãrurilor de LiGLA sã fie o combinație a unor efecte separate şi individuale ale acizilor graşi esenţiali şi ale ionului de litiu. Teste clinice sunt în derulare asupra cancerului pancreatic, un caz particular de tumorã agresivã cu un timp relativ de supraviețuire scurt în circumstanțe naturale. LiGLA este de asemenea citotoxic fațã de celulele infectate HIV, iar acest lucru poate avea o semnificație viitoare în tratamentul AIDS. Dacă respectarea dozei terapeutice determină reacții benefice, depăşirea acesteia declanşează o serie de perturbări care duc până la moartea individului. (Aschner et all, 1995)

Celulele gliale asigură tamponarea mediului intercelular şi permit desfăşurarea normală a activității neuronale. Prin creşterea concentrației $\mathrm{K}^{+}$extracelular datorită unei activităţi neuronale intense se poate produce depolarizarea membranei şi blocarea potenţialului de acțiune. Membrana astrocitelor este selectivă pentru $\mathrm{K}^{+}$şi răspunde la concentrații crescute de $\mathrm{K}_{\mathrm{e}}^{+}$prin depolarizare. 
Mai mult, captarea $\mathrm{K}^{+}$de către celulele gliale este asociată cu intensificarea metabolismului energetic şi alterarea sintezei macromoleculelor. Celulele gliale înconjoară numeroase sinapse astfel încât modulează funcția şi activitatea sinaptică. Este bine cunoscut că neuroglia sintetizează şi metabolizează o serie de neurotransmiţători şi neuromodulatori precum GABA, glutamat, aspartat dar mecanismul de eliberare a gliotransmiţătorilor nu este ĩncã bine stabilit.

Dezvoltarea unui sistem ştiinţific, standardizat, sigur şi validat clinic, de clasificare a tulburãrilor mentale, Diagnostic, Statistical Manual of Mental Disorders, ediţia a patra revizuitã (DSM-IV-R) a fãcut posibilã identificarea de rutinã şi diagnosticarea tulburãrilor mentale care necesitã tratament. Astfel, baza practicii clinice moderne psihiatrice, la fel cu cea a medicinii interne, se bazeazã în principal pe diagnostic, care dicteazã în schimb tipul de tratament prescris şi are o înaltã predicție asupra rezultatului clinic.

Tulburãrile afective sunt caracterizate prin exagerãri pãtrunzãtoare, prelungite şi "infirmizante" ale dispoziţiei şi afectivitãţii care sunt asociate cu disfuncții comportamentale, psihologice, cognitive, neurochimice şi psihomotorii. Sindroamele afective majore sunt tulburarea depresivã majorã (denumitã şi tulburare unipolarã), tulburare bipolarã (denumitã şi psihozã maniaco-depresivã sau depresie bipolarã) şi tulburarea distimicã. Clasificarea tulburãrilor afective în unipolare şi bipolare are utilitate clinicã deoarece aceste entitãți, deşi strâns legate, sunt diferite psihologic, cu câteva caracteristici clinice, forme de boalã şi tratamente diferite.

Dintre bolile psihice, tulburãrile afective sunt situate pe al doilea loc în ceea ce priveşte frecvența, afectând 5,1 \% din populația SUA în vârstã de peste 18 ani la un moment dat (prevalența pe o lunã). Prevalența pe o lunã pentru tulburarea depresivã majorã este de $2,2 \%$, pentru tulburarea bipolarã de $0,4 \%$, iar pentru tulburarea distimicã de 3,3 procente. Prevalența pe 1 an pentru toate tulburãrile afective este de 9,5 procente, indicând faptul cã acest tip de afecțiune se numãrã printre cele mai frecvente îmbolnãviri ale omului.

În cadrul patologiei majore, tulburarea afectivã bipolarã ocupã un rol important atât prin severitatea simptomelor, cât şi prin afectarea relaționãrii profesionale, familiale şi sociale a pacietului.

Frecvența acestei tulburãri este de 1\% ĩn populaţia generalã. Din punct de vedere clinic afecțiunea se caracterizeazã prin prezența a doua tipuri de episoade (faze): expansive (maniacale) şi depresive. Etiologia bolii este multifactoriala şi include: factori genetici, neurobiochimici, neuroanatomici, psihologici şi sociali.

Evenimentele stresante de viaţã (decesul partenerului, separarea, pierderea slujbei etc.) ĩşi pun amprenta ĩn declanşarea unui episod depresiv. Tulburarea depresiva este mai frecventã la varsta medie cuprinsa ĩntre 25 şi 45 ani şi la sexul feminin, care prezinta o vulnerabilitate crescuta la evenimente stresante. 
Mai multe gene sunt implicate în vulnerabilitatea şi capacitatea noastrã de a manifesta schimbãri ale activitãţii şi dispoziției afective. Date de geneticã molecularã sunt compatibile cu concepte dimensionale care sugereazã diferențe mai degrabã cantitative decât calitative între afecțiunile bipolare şi cele unipolare (Angst, 2006).

În sângele uman, ionii de litiu pot interfera cu aproape orice proces care implică ioni de sodiu, potasiu, calciu, magneziu, calmodulină, diferiţi mesageri secundari, hormoni şi mulți din neurotransmițătorii cunoscuți (Klemfuss et all, 1991).

Acțiunea terapeutică a sărurilor de litiu în bolile bipolare pare a fi rezultatul unui cumul de evenimente care modifică activitatea neuronală la nivele multiple.

Trei mecanisme care interacționează par a fi mai afectate:

1) modularea neurotransmițătorilor de către ionii de litiu pare a modifica raportul dintre activităţile lor excitatorii şi inhibitorii iar descreşterea activităţii glutamatergice poate contribui la efectul litiului de neuroprotecție;

2) ionii de litiu modulează semnalele cu impact asupra citoscheletului, un sistem dinamic care contribuie la plasticitatea neuronală la nivele multiple, inclusiv glicogen sintaza kinaza-3 $\beta$, protein kinază cAMP dependentă şi protein kinaza C;

3) ionii de litiu modifică activităţile de semnalizare care implică mesagerii secundari, factorii de transcripţie şi deci expresia genelor (Jope, 1999).

Acțiunile biologice ale sărurilor de litiu:

-inhibă adenilat ciclaza (Schimmer, 1973; Geiser et all, 1988; del Rio et all, 1998; Singh et all, 1998; Subbash et all, 1999).

-inhibă inozitol monofosfataza (Ragan et all, 1988; Chang et all, 1998; Belmaker et all, 1998) -interferă cu legarea altor cationi (Klemfuss et all, 1991)

-depolarizează neuronii (Grafe et all, 1983)

-blochează canalele ionice (Reiser et all, 1982)

-alterează compoziţia lipidelor (Shears, 1988; Einat et all, 1998; Dixon et all, 1997; Singh et all, 1998; Belmaker et all, 1998)

-inhibă sinteza cGMP (Geiser et all, 1988; Avissar et all, 1988; Berridge et all, 1989)

-desensibilizează receptorul pentru serotonină (Geisser et all, 1988)

-scade nivelul potasiului intracelular (Grafe et all, 1983; Birch et all, 1991)

-stimulează $\mathrm{Na}^{+}-\mathrm{K}^{+}$ATP-aza (Zachariah et all, 1991; Dixon et all, 1997)

-alterează neurotransmițătorii (Cowburn et all, 1988)

-afectează funcționarea proteinelor G (Dixon et all, 1997; del Rio et all, 1998; Jakobsen et all,1998)

-determină activarea protein kinazei C (Jope, 1999; Chen et all, 1998; Chang et all, 1998)

-reglează homeostazia calciului (Nonaka et all, 1998; del Rio et all, 1998; Singh et all, 1998)

-reduce nivelul mioinozitolului (Jakobsen et all, 1998; Manji et all, 1995)

-măreşte nivelul tirozin hidroxilazei (Chen et all, 1998)

-stimulează sinteza DNA la concentrații de 0,5-7, 5 mM (Toback, 1980)

-inhibă fosfolipaza $\mathrm{A}_{2}$ şi reduce turnoverul acidului arahidonic (Chang et all, 1998; Rintala et all, 1999)

-alterează fosforilarea proteinelor (Singh et all, 1998; Manji et all, 1995). 


\section{Proprietățile fizice şi chimice ale ionilor de litiu}

Litiul (în limba greacă, „lithos” ĩnsemnând piatră) este un element chimic cu simbolul Li şi numãr atomic 3, teoretic creat ĩn primele trei minute ale universului prin procesul denumit Big-Bang de nucleosintezã.

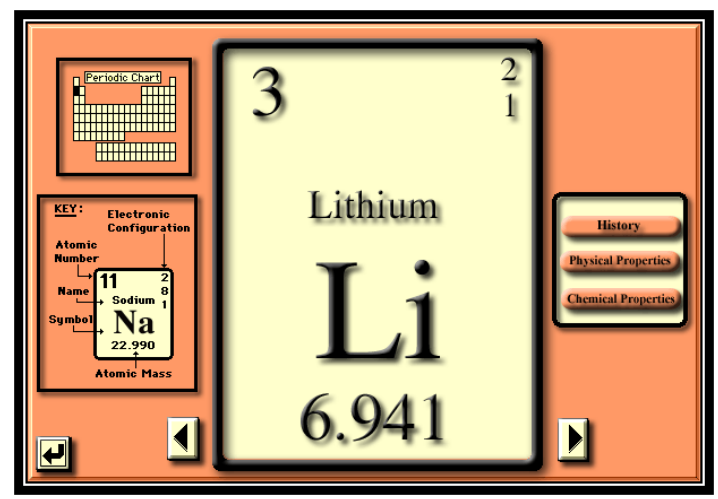

Fig. 2 Poziția Li ĩn tabelul periodic al elementelor

Conform teoriei, litiul (mai ales ${ }^{7} \mathrm{Li}$ ) a fost unul dintre puținele elemente sintetizate în urma Big Bang, deşi cantitatea lui a scăzut semnificativ. Motivele dispariţiei şi procesele prin care litiul este produs continua să fie unul dintre studiile importante din astronomie.

Litiul este al 33-lea element ca abundență pe Pământ dar, datorită mari lui reactivităţi, îl gasim numai sub formă de compuşi. Litiul se găseşte în zăcăminte pegmatitice, dar se poate obţine de asemenea din apa de mare şi argilă; la scarã industrială, litiul este izolat electrolitic dintr-o mixturã de clorura de litiu şi clorura de potasiu.

Berzelius 1-a denumit LITHION. Litiul se aflã ĩn grupa I a tabelului periodic, printre metalele alkaline, fiind cel mai uşor element solid. Metalele alkaline sunt denumite astfel pentru cã pot forma alkali (baze puternice capabile sã neutralizeze acizi) când se combinã cu alte elemente.

Petalitul, care conţine litiu, a fost descoperit de cercetãtorul brazilian José Bonifácio de Andrada e Silva pe la sfârşitul anilor 1700 ĩntr-o cãlãtorie ĩn Suedia. Litiul a fost descoperit în 1817 de către Johann Arfvedson (în Suedia).

Arfvedson a gãsit noul element ĩn mineralele de spodumen şi lepidolit ĩntr-un minereu de petalitã, $\mathrm{Li} \underline{\mathrm{Al}}\left(\underline{\mathrm{Si}}_{2} \underline{\mathrm{O}}_{5}\right)_{2}$, pe care îl analiza ĩntr-o investigație de rutinã a unor minerale din mina islandezã Utö.

În 1818 Christian Gmelin a fost primul care a observat cã sãrurile de litiu produc o culoare roşie strãlucitoare ĩn flacãrã. Ambii cercetãtori au ĩncercat, dar fãrã succes, sã izoleze elementul din sãrurile pe care acesta le formeazã. 
Elementul nu a putut fi izolat decât dupã ce William Thomas Brande şi Sir Humphrey Davy mai târziu au utilizat electroliza oxidului de litiu ĩn 1818.

A fost izolat pentru prima dată în cantităţi apreciabile în 1855 de către Bunsen şi Mathiessen prin electroliza clorurii de litiu în stare topită, metodă folosită şi în prezent pentru obținerea litiului.

Litiul este folosit pentru aliaje (împreună cu sodiul şi calciul). De asemenea, se foloseşte ca dezoxidant, desulfurizant şi degazant pentru cupru. Litiul se mai întrebuințează pentru pentru prepararea tritiului, ${ }^{3} \mathrm{H}$.

Cantităţi mici de litiu se găsesc ĩn apa oceanelor şi în unele organisme vii cu toate ca s-a constatat că nu îndeplineşte nici o necesitate biologica pentru organismul uman. Totuşi, efectul neurologic al ionilor de litiu $\mathrm{Li}^{+}$, face ca unele săruri de litiu să fie folosite ca medicamente pentru îmbunătățirea stării de dispoziție.

Litiul şi compuşii săi au şi alte câteva aplicaţii industriale, incluzând sticlă si ceramică termorezistentă, aliaje de mare rezistență şi cu greutate redusă folosite în aeronautică şi nu în ultimul rând bateriile alcaline cu litiu. Litiul, de asemenea are un rol important în fizica nucleară: fisiunea atomilor de litiu a fost prima reacție nucleara efectuata de cãtre omenire, şi deuteritiul de litiu este combustibilul pentru armele termonucleare.

Mai puțin de 1\% este utilizat în medicină (Birch, 1999), în tratamentul gutei, ca urat de litiu (una dintre puținele săruri solubile ale acidului uric) şi în tratamentul unor tulburări psihice, sub formă de carbonat de litiu $\left(\mathrm{Li}_{2} \mathrm{CO}_{3}\right)$ sau alte săruri.

Litiul este primul element al grupei metalelor alcaline (I-a), dar prezintă proprietăţi diferite comparativ cu celelalte elemente ale grupei (sodiul, potasiul, rubidiul, cesiul şi franciul). Litiul concurează cu magneziul pentru situsurile catalitice de legare la substrat ale enzimelor, datorită similarității proprietăţilor lui fizice şi chimice cu cele ale magneziului (relație diagonală). Razele ionilor de litiu şi magneziu sunt aproape egale.

Litiul este cel mai uşor metal solid, având cea mai mică densitate $(0,53$ $\mathrm{g} / \mathrm{cm}^{3}$ ) şi pluteşte în petrol. Acest element este de culoare alb-argintie, moale (poate fi tăiat cu un cuțit) şi arde cu flacără strălucitoare ca şi magneziul. Litiul se combină uşor cu oxigenul din aerul uscat formând la suprafață un strat de oxid de litiu de culoare gri. Din acest motiv se păstrează sub un strat protector de petrol sau parafină lichidă, care previne oxidarea.

Litiul are luciu metalic în tăietură proaspătă sau prin îndepărtarea stratului de oxid. Temperatura de topire a litiului este cea mai înaltă în comparație cu restul metalelor alcaline.

Conductibilitatea termică şi electrică a litiului este mare. Cristalizează într-o cubică centrată intern. În rețea, atomii metalului ocupă vârfurile şi centrul spaţial al unui cub, încât fiecare atom de litiu este înconjurat de alţi opt atomi.

Litiul este un metal alcalin care are structura învelişului electronic [He] $2 \mathrm{~s}^{1}$, starea de oxidare +1 , fiind elementul cel mai puțin reactiv (electropozitiv) din grupa Ia 
a sistemului periodic. El este un metal uşor; având densitatea $0,53 \mathrm{~g} / \mathrm{cm}^{3}$ pluteşte în petrol. In soluții apoase, litiul suferă un proces de hidratare, energia de hidratare fiind $-124 \mathrm{Kcal} / \mathrm{mol}$.

Litiul formează în principal combinații ionice, având proprietăți chimice similare magneziului din grupa a-II-a.

Halogenurile de litiu sunt solubile în apă, cu excepția fluorurii de litiu. Clorura de litiu este higroscopică cristalizând cu 1, 2 sau 3 molecule de apă în funcție de temperatură. Carbonatul şi fosfatul de litiu sunt insolubile în apă (Birch, 1999).

Litiul descompune apa; în aer se aprinde formând oxidul de litiu, $\mathrm{Li}_{2} \mathrm{O}$. Încălzit în atmosferă de hidrogen formează hidrura de litiu, $\mathrm{LiH}$, care este cea mai stabilă dintre hidrurile metalelor alcaline. Litiul este singurul metal alcalin care se combină direct cu azotul la rece, formând nitrura, $\mathrm{Li}_{3} \mathrm{~N}$; de asemenea, se combină direct la cald cu halogenii formând halogenuri, $\mathrm{LiX}$, cu sulf, formând sulfura, $\mathrm{Li}_{2} \mathrm{~S}$, cu carbonul, formând carbura, $\mathrm{Li}_{2} \mathrm{C}_{2}$, cu siliciul, formând siliciura, $\mathrm{Li}_{6} \mathrm{Si}_{2}$, etc.

Litiu este cel mai mic metal cunoscut, cu o masă atomică de 6,9. In mod normal, litiul este prezent sub forma unui amestec de izotopi: 7,4\% $\mathrm{Li}^{6}$ şi $92,6 \% \mathrm{Li}^{7}$ (Thellier et all, 1997). In natură, litiu există numai în stare ionică sub formă de săruri şi nu este considerat a fi unul dintre elementele biologic esenţiale pentru om (Birch et all, 1998; Gallicchio, 1992).

Acest metal nu prezintă un mecanism de reglare, nu are prag de eliminare, este toxic pentru organism peste doza terapeutică, nu se leagă de proteine şi difuzează uşor în spaţiul intra- şi extracelular (Uluitu, 1991).

Litiul poate fi detectat în compuşii săi datorită colorării sale caracteristice în roşu carmin la flacăra incoloră a becului de gaz şi prin metode de spectroscopie. Litiul emite puternic în roşu $(671 \mathrm{~nm})$ şi mai slab în portocaliu.

Clorura de litiu $(\mathrm{LiCl})$ este o substanță cristalină, ionică, cu masa moleculară 42.39. Este anhidră şi higroscopică (absoarbe apa din mediul înconjurător formând hidrați sau chiar soluții, ca şi halogenurile grupei a II-a). Cristalizează cu una, două sau trei molecule de apă, în funcție de temperatură şi se dizolvă în etanol şi în alţi compuşi organici oxigenați. Clorura de litiu este mai toxică decât carbonatul de litiu şi nu este folosită în tratamentul psihozelor.

Carbonatul de litiu este un compus ionic, solid (pulbere) de culoare albă, alcalin, greu solubil în apă, cu masa moleculară 73.89. Este folosit în tratamentul tulburărilor afective bipolare, depresii, manii. 


\begin{tabular}{|c|c|c|c|c|c|c|}
\hline \multicolumn{7}{|c|}{ General } \\
\hline \multirow{2}{*}{\multicolumn{3}{|c|}{$\begin{array}{l}\text { Nume, Simbol, Numãr atomic } \\
\text { Seria chimicã }\end{array}$}} & \multicolumn{4}{|c|}{ Litiu, Li, 3} \\
\hline & & & \multicolumn{4}{|c|}{ metale alkaline } \\
\hline \multicolumn{3}{|c|}{ Grupa, Perioada, Strat } & \multicolumn{4}{|c|}{$1,2, \mathrm{~s}$} \\
\hline \multicolumn{3}{|c|}{ Aparențã } & \multicolumn{4}{|c|}{ silvery white/grey } \\
\hline \multicolumn{3}{|c|}{ Masã atomicã } & \multicolumn{4}{|c|}{$6.941(2) \mathrm{g} / \mathrm{mol}$} \\
\hline \multicolumn{3}{|c|}{ Configurație electronicã } & \multicolumn{4}{|c|}{$1 s^{2} 2 s^{1}$} \\
\hline \multicolumn{3}{|c|}{ Electroni per strat } & \multicolumn{4}{|c|}{2,1} \\
\hline \multicolumn{7}{|c|}{ Proprietãți fizice } \\
\hline \multicolumn{3}{|l|}{ Stare } & \multicolumn{4}{|c|}{ solid } \\
\hline \multicolumn{3}{|c|}{ Densitate } & \multicolumn{4}{|c|}{$0.534 \mathrm{~g} \cdot \mathrm{cm}^{-3}$} \\
\hline \multicolumn{3}{|c|}{ Densitatea lichidului la punctul de topire } & \multicolumn{4}{|c|}{$0.512 \mathrm{~g} \cdot \mathrm{cm}^{-3}$} \\
\hline \multicolumn{3}{|c|}{ Punct de topire } & \multicolumn{4}{|c|}{$453.69 \mathrm{~K}\left(180.54^{\circ} \underline{\mathrm{C}}, 356.97^{\circ} \mathrm{F}\right)$} \\
\hline \multicolumn{3}{|c|}{ Punct de fierbere } & 161 & $2^{\circ} \mathrm{C}, 24$ & & \\
\hline Punct cri & & & $(\mathrm{ext}$ & $3223 \mathrm{~K}$ & & \\
\hline Cãldura & & & 3.00 & & & \\
\hline Cãldura & are & & 147 & & & \\
\hline Capacita & & & $(25$ & $0 \mathrm{~J} \cdot \mathrm{mol}$ & & \\
\hline & & & nea $v$ & & & \\
\hline$P / \mathrm{Pa}$ & 1 & 10 & 100 & $1 \mathrm{k}$ & $10 \mathrm{k}$ & $100 \mathrm{k}$ \\
\hline at $T / \mathrm{K}$ & 797 & 885 & 995 & 1144 & 1337 & 1610 \\
\hline & & & priet & & & \\
\hline Structura & & & cubi & ntered & & \\
\hline Stãri de & & & $1(\mathrm{~s}$ & sic oxic & & \\
\hline Electron & & & 0.98 & scale) & & \\
\hline Energii d & & & 1st: & mol & & \\
\hline & & & $2 \mathrm{nd}$ & $\mathrm{J} / \mathrm{mol}$ & & \\
\hline & & & 3rd: & $\mathrm{kJ} / \mathrm{mol}$ & & \\
\hline Raza ato & & & 145 & & & \\
\hline Razã ato & & & 167 & & & \\
\hline Razã cov & & & 134 & & & \\
\hline Razã Va1 & & & 182 & & & \\
\hline & & & Di & & & \\
\hline Ordine $\mathrm{n}$ & & & non & & & \\
\hline Rezistivi & & & $(20$ & $\Omega \cdot \mathrm{m}$ & & \\
\hline Conducti & micã & & $(300$ & $\left.\mathrm{W} \cdot \mathrm{m}^{-1} \cdot\right]$ & & \\
\hline Expansiu & & & $(25$ & $\mathrm{a} \cdot \mathrm{m}^{-1} \cdot \mathrm{K}$ & & \\
\hline Viteza su & hin rod & & $(20$ & $\mathrm{m} / \mathrm{s}$ & & \\
\hline Modul Y & & & 4.9 & & & \\
\hline Modul S & & & 4.2 & & & \\
\hline Modul B & & & 11 & & & \\
\hline Duritate & & & 0.6 & & & \\
\hline & & & Izc & & & \\
\hline
\end{tabular}

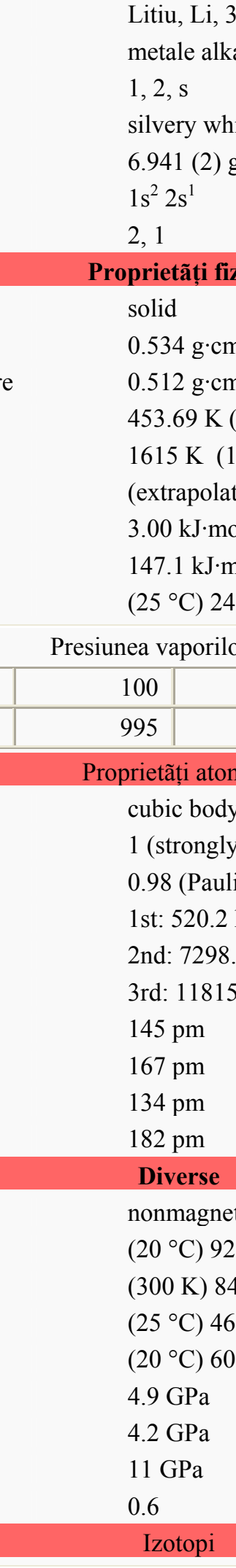

Main article: Isotopes of lithium

\begin{tabular}{|c|c|c|c|c|c|}
\hline iso & NA & half-life & DM & DE $(\mathrm{MeV})$ & DP \\
\hline${ }^{6} \mathrm{Li}$ & $7.5 \%$ & \multicolumn{4}{|c|}{$\mathrm{Li}$ is stable with 3 neutrons } \\
\hline${ }^{7} \mathrm{Li}$ & $92.5 \%$ & \multicolumn{4}{|c|}{$\mathrm{Li}$ is stable with 4 neutrons } \\
\hline
\end{tabular}




\section{Litiul ca element secundar ĩn organism}

Litiu se gãseşte în cantitãţi infime în toate tipurile de sol, mai ales în fracția luteicã (argiloasã), şi mai puţin în fracția de sol organicã, în cantitãti situate ĩntre 7 şi $200 \mu \mathrm{g} / \mathrm{g}$. Este, de asemenea, prezent în apele de suprafaţã, la nivele între 1 şi $10 \mu \mathrm{g} / \mathrm{L}$, iar în apa mãrii la o concentrație de $0.18 \mu \mathrm{g} / \mathrm{L}$. Concentrațiile de litiu în apele subterane ajung la $500 \mu \mathrm{g} / \mathrm{L}$. În unele ape de râu se ajunge la o concentraţie de litiu de pânã la $8 \mathrm{mg}$ L. Existã ape minerale naturale cu cantitãți mari de litiu, cu nivele ce ating pânã la $100 \mathrm{mg} / \mathrm{L}$.

Litiu este preluat din sol de toate plantele, deşi el nu apare sã fie necesar pentru creşterea şi dezvoltarea lor. La nivele înalte în sol, Li este toxic pentru toate plantele, cauzând o conditie similarã chlorozei. Preluarea şi sensibilitatea la litiul sunt dependente de specie. Unele plante, ĩn mod remarcabil Cirisum arvense şi Solanum dulcamera, acumuleazã litiu de trei pânã la şase ori mai mult decât alte plante. Plantele halofile, ca de exemplu Carduus arvense şi Haloschoenus vulgaris pot sã atingã un conținut de litiu de 99,6 - 226,4 $\mu \mathrm{g} / \mathrm{g}$.

Litiu este relativ toxic la plantele citrice; speciile active la umbra nopții sunt în mod remarcabil mai tolerante la litiul şi au un conținut de litiu de pânã la $1000 \mu \mathrm{g} / \mathrm{g}$. Drojdiile (Saccharomyces Cerevisiae) preiau cantitãții limitate de litiu, nivelele ridicate de litiu (115-400 ppm) în mediu pot sã cauzeze inhibiţia creşterii. În general, mai mult litiu este preluat de plantele de pe solurile acide decât de pe cele alcaline. Aciditatea solului sporeşte solubilitatea elementelor metalice mai grele, nivelul litiului ĩ plante fiind direct şi semnificativ corelat cu cel al fierului, nichelului, cobaltului, magneziului şi cuprului, şi într-o oarecare mãsurã cu cel de aluminiu şi cadmiu.

Litiu se gãseşte ĩn cantitãţi variabile în hranã: sursele alimentare principale sunt grânele şi zarzavatul; În anumite regiuni, apa potabilã, de asemenea, furnizeazã cantitãti semnificative ale elementului. Aportul de litiu ĩn dieta umanã depinde de amplasarea şi tipul de hranã consumat şi varieazã cantitativ ĩntre 650 şi $3100 \mu \mathrm{g}$. Urmele de litiu au fost detectate în organele umane şi țesuturile fetale ĩncã din secolul al XIX-lea, ducând la sugestia timpurie cã are anumite funcții specifice în organsism. Oricum, a luat un alt secol pânã ce s-au adus dovezi pentru rolul esenţial al litiului.

Litiului ingerat sub forma sãrurilor sale solubile este absorbit la nivelul intestinului subţire, virtual $100 \%$ prin canalele de $\mathrm{Na}+$ naturale şi este secretat ĩn principal la nivelul rinichilor. Litiul absorbit este în mod uniform distribuit în apa din corp, cu numai o micã diferenţã între nivelul celular şi cel interstiţial.

Studiile dupã autopsie a unor adulți au arãtat cã cerebelul reține mai mult litiu decât alte organe, urmat de encefal şi rinichi. Nivelul litiului în diferite organe aratã diferențe de gen inexplicabile, femeile având ĩntre 10 şi 20\% mai mult litiu în cerebel, encefal, rinichi şi cord şi 13\% mai puțin Li în pancreas; Nivelul litiului în pancreas; ficat, plãmâni, coaste şi tiroidã a fost asemãnãtor la ambele genuri. 
În timpul dezvoltãrii embrionare, litiul are valori maxime în primul trimestru de sarcinã şi ulterior ĩnregistreazã un declin, aşa cum este şi cazul altor microelemente. La sfârşit trimestrului trei, concentrația de litiu a fetuşilor este de $1 / 3$ din cea a primelor trimestre. Continutul de litiu al rinichilor, ficatului şi coastelor continuã sã scadã în primii cinci pânã la zece ani de viațã, iar nivelul sãu ĩn prostatã continuã sã scadã pe întreaga duratã de viațã.

Concentrația de litiu ĩn ser este aproximativ proporționalã cu aportul de litiu. La adulții primind $0.25 \mathrm{mM}(1,74 \mathrm{mg})$ de litiu sub formã de clorurã per zi pentru câteva sãptãmâni, de exemplu, nivelul seric al litiului crește de la un nivel de bazã $0.14 \pm$ $0.03 \mu \mathrm{mol} / \mathrm{L}$ la $3.9 \pm 0.08 \mu \mathrm{mol} / \mathrm{L}$ (sau de la $0.97 \pm 0.21$ la $27.0 \pm 5.5 \mu \mathrm{g} / \mathrm{L}$ ). La numai jumãtate de dozã, adicã $0.125 \mathrm{mM}(0.87 \mathrm{mg})$ de litiu per zi, concentrția litiului ĩn ser ĩn stare staționarã a fost de $2.6 \mu \mathrm{mol} / \mathrm{L}(18 \mu \mathrm{g} / \mathrm{L})$. La doze zilnice egale de $\mathrm{Li}$, greutatea şi înãlțimea corpui indivizilor au fost invers corelate cu nivelul seric al litiului; descreşterea concentrației litiului cu $0.57 \mu \mathrm{mol} / \mathrm{L}$ duce la o creştere cu $10 \mathrm{~cm}$ în înãlțime, iar scãderea concentrației litiului cu $0.38 \mu \mathrm{mol} / \mathrm{L}$ determinã o creştere cu 10 $\mathrm{kg}$ în greutate.

Nivelul seric bazal al litiului la adulți se ĩncadreazã ĩn domeniul cuprins ĩntre 7 şi $28 \mu \mathrm{g} / \mathrm{L}$, corespunzând unor admisii de litiu zilnice de 385-1540 $\mu \mathrm{g}$. Concentraţia de litiu din pãr reflectã admisiile medii de litiul disponibil ĩntr-o perioadã de la câteva sãptãmâni pânã la câteva luni şi reprezintã o metodã neinvazivã de a determina aportul necesar de litiu ĩn dietã. Conținutul de litiu din pãr reflectã, de asemenea, nivelul de litiu la animale. Litiul din pãr la adulți se aflã ĩn concentrații cuprinse ĩntre 0.009 şi $0.228 \mu \mathrm{g} / \mathrm{g}$; valorile sunt puțin mai mari pentru femele decât pentru masculi. De la aceste date, s-a calculat cã necesarul zilnic mediu de litiu este de $650 \mu \mathrm{g}$, domeniu ĩn care poate varia fiind ĩntre 100 şi $2645 \mu \mathrm{g} / \mathrm{zi}$. Nivelul de litiul din pãr creşte proporțional cu doza la indivizii umani care primesc ĩntre 1000 şi $2000 \mu \mathrm{g}$ de litiul într-un supliment de dietã, ajungând la o stare de regim staționar dupã circa trei luni de suplimentare. $\mathrm{Cu}$ toate aceastea, proporționalitatea nu se extinde la intrãrile de litiu farmacologice; prin urmare nivelul de litiul din pãr nu poate sã fie utilizat pentru a monitoriza conformitatea dozei la pacienții tratați cu carbonat de litiu.

În studii desfãşurate ĩntre anii 1970 şi 1990, şobolani şi capre ținute la diete cu concentrații mici de litiul au prezentat o mortalitate mai ridicatã şi de asemenea anomalii de reproducere şi de comportament. Deficiența ĩn litiu la om nu a fost caracterizatã, dar intrãri joase de litiu prin alimentație şi consumul de apã au fost asociate cu un nivel ridicat de suicid, omucideri şi rate ridicate de consum de droguri şi alte infracțiuni. Folosind datele privind rata de infracționalitate dintre anii 1978-1987, Schrauzer şi Shrestha au observat asociații inverse semnificative statistic $(p=$ la 0.01$)$ între litiul din apa consumatã şi ratele de omucidere, sinucidere şi rãpire forțatã. Asociații semnificative inverse ( $\mathrm{p}=$ la 0.01$)$ au fost de asemenea au observate cu ratele de arestare pentru spargeri şi hoție, posesie de droguri şi fuga tinerilor de acasã. 
Într-un studiu ulterior, nivelul litiului din pãrul scalpului al condamnaților violenţi din California a fost de $0.028 \pm 0.029 \mu \mathrm{g} / \mathrm{g}$, semnificativ mai puțin decât ĩn cazul indivizilor de control cu un nivel de litiu mediu de $0.099 \pm 0.126 \mu \mathrm{g} / \mathrm{g}$, deşi acest fapt nu reprezintã neapãrat o relație cauzalã.

Efectele deficienței litiului asupra caracteristicilor de comportament au fost demonstrate în studii pe şobolani. Şobolanii cu un regim cu deficit de litiu $(0.0066 \mu \mathrm{g}$ Li/g hranã) au arãtat un nivel de comportament lipsit de reprimãri fațã de animalele cu un regim Li-suplimentat $(0.11 \mu \mathrm{g} / \mathrm{g}$ hranã). Comportarea şobolanilor cu deficit de Li sa normalizat prin suplimentarea cu litiu a hranei.

Într-un alt studiu, Klemfuss şi Schrauzer au arãtat cã şobolanii cu un regim Lideficient $(<0.01 \mu \mathrm{g} \mathrm{Li} / \mathrm{g})$ şi apã de bãut având $31 \mu \mathrm{M} \mathrm{NaCl}$ au prezentat scãderi ale activitãții Wheel-running, scãderi ale rãspunsului la manipulare şi mai puținã agresivitate ĩn interacțiunile sociale comparativ cu şobolanii care aveau aceeaşi dietã dar cu $31 \mu \mathrm{M}(215 \mu \mathrm{g} \mathrm{Li} / \mathrm{L}$ de $\mathrm{LiCl}$ în apa potabilã.

Litiu joacã un rol special important în timpul dezvoltãrii embrionare timpurii aşa cum evidențiazã conținutul ridicat de litiu al embrionului în perioada timpurie de gestație. Studii pe animale au demonstrat cã litiul joacã un rol important în expansiunea celulelor pluripotente. La şoareci, clorura de litiu a sporit numãrul celulelor pluripotente şi ulterior numãrul celulelor precursoare, iar mai târziu a crescut nivelul factorilor de creştere hematopoietici şi elementele figurate din sânge.

Pentru om, dovezile existente sugereazã cã asigurarea aportului adecvat de Li pentru populaţia generalã ar putea sã determine un grad de sãnãtate sporit şi beneficiile unor relații sociale normale. Argumentele experimentale sunt suficiente pentru a accepta cã litiul este un element secundar esențial. Alimentația unui adult de $70 \mathrm{Kg}$ trebuie sã cuprindã un aport de $1000 \mu \mathrm{g} \mathrm{Li} / \mathrm{Zi}$, corespunzând unor intrãri de 14,3 $\mu \mathrm{g} \mathrm{Li}$ / kg greutate corporalã. Acest nivel poate fi atins printr-un regim alimentar simplu în unele regiuni Li-adecvate. Pentru indivizii care trãiesc cu regimuri speciale sau pentru populații ce locuiesc în zone cu deficit de Li, suplimentarea cu litiu trebuie sã rãspundã acestui necesar zilnic.

O atenție specialã ar trebui sã fie acordatã copiilor, cu nevoi potențial mai ridicate de litiu, adolescenţilor şi mamelor care alãpteazã. Nevoile de litiu ar putea fi mai mari dupã efort fizic, în anumite boli şi la pacienții ĩn dializã. $O$ furnizare adecvatã de Li ar trebui de asemenea sã fie asiguratã indivizilor cu nutriţie sub regim şi la cei care sunt hrãniţi ĩndelung parenteral (Schrauzer, 2002).

La om, nivelul seric endogen al litiului este normal ĩn domeniul $0,14-8,6 \mu \mathrm{M} / 1$, cu un nivel maxim de 15,8 $\mu \mathrm{M} / 1$. Aceste concentrații serice de litiu sunt cu 3 ordine de mãrime mai mici decât cele necesare pentru tratamentul terapeutic sau profilactic. Cercetãtorii bãnuiesc cã nivelul endogen de litiu din corpul uman are o funcție fiziologicã, deşi nu existã ĩncã dovezi suficiente ĩn acest sens. 


\section{Transportul ionilor de litiu prin membrana celulară.}

Intrarea de litiu în organismul uman depinde atât de alimentație cât şi de folosirea de medicamente care conțin litiu. Tratamentul cu litiu nu trebuie sa depãşeascã o dozã maximã cuprinsã ĩntre $15 \mu \mathrm{mol}$ şi $0,66 \mathrm{mmol}$ de litiu pe zi.

Dupã observațiile lui Cade din 1949, numeroase studii au explorat mecanismele potențiale ale acțiunii terapeutice a litiului în tratamentul maniaco-depresiei. Studiile timpurii s-au concentrat pe proprietatea litiului de a fi un cation monovalent, pe rolul sãu în transportul sodiului, şi efectul lui asupra aspectelor fiziologice ale celulelor (Lenox et all, 1998).

Litiu poate fi transportat prin membrane în cinci moduri diferite. Dintre acestea, fluxul pasiv este cea mai importantã cale de intrare pentru litiu în celule, iar cotransportul sodiu-litiul pentru expulzarea litiului din celule. Cele cinci componentele ale transportului de Li+ sunt (Reiser şi Duhm, 1982):

1. Sistemul de transport antiport $\mathrm{Na}^{+}$- dependent transportã $\mathrm{Li}+$ în ambele direcții prin membrana plasmaticã. Aceastã calea de transport este insensibilã la ouabainã şi $\mathrm{K}^{+}$extern. Calea de transport prezintã trans-stimularea (accelerarea expulzãrii $\mathrm{Li}+$ la stimulareã externã cu $\mathrm{Na}^{+}$şi a preluãrii $\mathrm{Li}+$ la creşterea $\mathrm{Na}+$ intern) şi cis-inhibiție micşorarea preluãrii $\mathrm{Li}+$ de cãtre $\mathrm{Na}+$ extern);

2. Pompa de $\mathrm{Na}^{+} / \mathrm{K}^{+}$mediazã preluarea $\mathrm{Li}^{+}$dar nu şi eliberarea sa din celule cu conținut fiziologic de $\mathrm{Na}^{+}$şi $\mathrm{K}^{+}$. Atât $\mathrm{Na}+$ cât şi $\mathrm{K}+$ extern inhibã preluarea de $\mathrm{Li}+$ de cãtre pompã pe medii cu colinã. În medii cu $\mathrm{Na}^{+}, \mathrm{K}^{+}$extern are un efect bifazic: ĩn concentrații de pânã la $1 \mathrm{mM}, \mathrm{K}^{+}$accelereazã, iar la concentrații mai mari inhibã preluarea de $\mathrm{Li}^{+}$uptake de cãtre pompã;

3. $\mathrm{Li}+$ poate sã intre ĩn celulã prin canalul de $\mathrm{Na}+$ voltaj-dependent . Intrarea litiului prin aceastã cale este stimulatã cu veratridinã şi toxina de scorpion, stimularea fiind blocatã tetrodotoxina.

4. Cãile reziduale cuprind o componentã saturabilã, care este comparabilã la preluarea bazalã de $\mathrm{Na}+$, şi,

5. o componentã ouabain-rezistã care determinã o expulzare a $\mathrm{Li}+$ împotriva gradientului electrochimic în mediile cu colinã.

Mecanismele expulzãrii $\mathrm{Li}+$ descrise aici explicã eventual cum celulele neuronale mențin o stare stabilã a raportului nivelului de $\mathrm{Li}^{+}$intern şi extern sub 1 în timpul expunerii cronice la o concentrație externã de 1-2 mM Li+.

Litiu poate sã înlocuiascã sodiul în sistemul de transport antiport sodiu-sodiu, deși semnificația biologicã a acestui sistem continuã încã sã fie neclarã. Aparent, concentrația de litiu în celule nu atinge nivelele prezise de ecuația Nernst. Mai degrabã, nivelul de litiu celular este mult redus decât concentrația lui în sânge sau fluidul intercelular. Acest aspect este important pentru modelele propuse pentru mecanismul sãu de acțiune, aceste modele trebuind sã explice efectele litiului la 
concentrații celulare de $0,1 \mathrm{mmol} / 1$ (similare cu cele observate la pacienți aflaţi sub tratament cu litiu).

O ipotezã sugereazã cã efectele biologice ale litiului au de-a face cu rolul jucat la periferia celulei, unde, de exemplu, influențeazã recunoaşterea celularã, mecanismele de semnalizare celularã, şi anumite procese imunologice.

Litiu este un ion mic şi foarte mobil, fiind dificil sã se defineascã distribuția lui în celulele vii. Încercãrile s-au fãcut folosind izotopii stabili 6-Li şi 7-Li. Localizarea celularã folosind tehnicile nucleare a avut rezultate. Majoritatea dovezilor privind nivelul litiului celular liber au fost dependente de analizele conţinutului celular şi ale extrapolãrii datelor privind transportul de litiu. Aceste tehnici nu pot face deosebirea între litiu din celule şi cel ataşat la, sau prins în capcana membranelor celulare.

Studii fãcute pe eritrocite umane şi animale şi pe celule obținute din alte surse de țesut animal au arãtat cã nivelul de litiu din eritrocite a fost sub $8 \%$ din cel extern dupã incubare într-un domeniu de concentrții externe de litiu între 2 şi $40 \mathrm{mmol} / 1$ pentru perioade de pânã la trei ore. Studiile pe eritrocite, hepatocite, fibroblaste şi astrocite au arãtat cã litiul nu se distribuie la echilibru conform potențialului membranar (în aceste exemple între -40 şi $-60 \mathrm{Mv}$ ). Acest lucru poate fi datorat fie unei permeabilitãți scãzute a membranei, fie unui mecanism alternativ de ejecție a ionului din celulã.

La ora actualã, nu este posibilã determinarea concentrãrilor de litiu în celulele iritabile. Un numãr de canale ionice sunt cunoscute a fi acceptoare de litiu cu relativã uşurinţã şi ĩn condiţii ideale celulele prezintã curenți semnificativi de litiu. Ehrlich şi Diamond au sugerat cã prin calculul ecuației Nernst ar trebui sã fie un exces înzecit de litiu într-o celulã iritabilã, comparativ cu cel exterior, menținând potenţialul normal. În realitate nu a fost posibil sã se detecteze un exces de litiu mai mare de patru ori.

Existã date care sugereazã cã celulele din creier nu acumuleazã mai mult litiu decât alte celule somatice. Existã o rezistențã semnificativ mai mare decât s-a crezut iniţial la influxul de litiu prin membranele celulare.

Un studiu realizat de Gow şi Ellis (1990) utilizând micro-electrozi cu ioni selectivi sugereazã cã ĩn fibrele Purkinje perfuzate cu o soluție de litiu-Tyrode, cu 70 $\mathrm{mmol} / \mathrm{L}$ litiu, nivelul intracelular maxim de litiu atinge $28 \mathrm{mmol} / \mathrm{l}$ ceea ce reflectã descreşterea concentrației de potasiu.

Acesta sugereazã cã excesul celular absolut determinat teoretic de Ehrlich şi Diamond (1983) ar putea sã nu existe în realitate iar rezultatele obţinute de Gow şi Ellis sugereazã cã este mai degrabã o proporție mai mare de litiu în celulele iritabile la nivele externe de litiu înalte decât în celulele non-excitabile la concentrații externe scãzute, raportul intracelular/extracelular al nivelului de litiu fiind tot subunitar.

Cazul preluãrii semnificative de litiu ĩn celule, chiar şi în celulele active electric, nu este suficient dovedit pentru a fi considerat cert şi reprezintã mai degrabã un caracter variabil, aspect frecvent ignorat în conceperea modelelor de acțiune farmacologicã a litiului. Cel mai multe teorii privind acțiunea litiului presupun o concentrație semnificativã a ionului de litiu ĩn compartimentul fluidului intercelular. 
Intenalizarea litiului în celule. Litiul utilizează, pentru intrarea în celulă, proteine transportoare implicate în transportul sodiului şi potasiului, înlocuindu-i pe aceştia. Principalele căi de intrare a litiului în celule sunt canalele de sodiu şi schimbătorul de $\mathrm{Na} / \mathrm{H}$. Ambele sunt proteine transportoare inhibate de amilorid (Lenox şi al., 1998).

Canalele de sodiu au rol în transportul sodiului de la exteriorul la interiorul celulei, în sensul gradientului de concentrație. Datorită permeabilităţii aproximativ egale a acestor canale pentru sodiu şi litiu, ionul de litiu le poate utiliza pentru a pătrunde în celulă fără consum energetic. Concentrația litiului creşte de 5-10 ori la nivelul dendritelor în urma unei salve de stimuli, aceasta explicându-se prin deschiderea unui număr mare de canale de sodiu în timpul potențialului de acțiune (Lenox şi al., 1998).

Numeroase tipuri celulare prezintă în membrană schimbătorul de $\mathrm{Na} / \mathrm{H}$, în principal cele din segmentul proximal al nefronului. $\mathrm{Cu}$ toate că viteza maximă de transport a schimbătorului pentru litiu este de două ori mai mică decât cea pentru sodiu, acesta reprezintă o cale majoră de intrare a litiului în celule ( Timmer şi Sands, 1999).

Cotransportul de Na-K-2Cl se găseşte în membrana apicală a celulelor de la nivelul porţiunii ascendente a ansei Henle şi este inhibat de furosemid (Lenox şi Hahn, 2000). Litiul pătrunde în celulă, substituind ionul de sodiu, dar randamentul transportului diferă în funcție de țesut şi de specie.

Cotransportorii dependenți de sodiu transportă activ aminoacizi, glucoză, grupări fosfat şi alte molecule mari în interiorul celulei, simport cu un ion de sodiu, activând cotransportorii cu randamente diferite în funcție de localizare. Efectul este de acumulare a litiului în concentrații mai mari la nivelul organelor ce prezintă un număr ridicat al cotransportorilor în celulă (Timmer şi Sands, 1999).

Exportul extracelular al litiului. Concentrațiile de litiu nu se echilibrează în mod pasiv prin membrană. Transportul litiului în exteriorul celulei se face cu consum de energie. Acest fapt este dovedit de diferențele apărute între raportul concentrațiilor celulă-plasmă în situația ipotetică a unei echilibrări pasive şi raportul concentrațiilor determinat in vivo. Căile de ieşire sunt mult mai limitate decât cele de intrare, ceea ce conduce la acumulare de litiu în celule (Timmer şi Sands, 1999).

Deşi este foarte răspândită în membrana celulară, ATP-aza de $\mathrm{Na} / \mathrm{K}$ nu este implicată în transportul litiului. Studiile pe eritrocite au dovedit că afinitatea ATP-azei pentru litiu este cel puțin cu un ordin de mărime mai mică decât cea pentru sodiu sau potasiu. Aceasta are ca rezultat incapacitatea legării litiului la situsurile pentru sodiu ale ATP-azei (Timmer şi Sands, 1999).

Unele studii au corelat însă nivelurile crescute de sodiu din celulele pacienților aflați în faza depresivă a psihozelor bipolare şi unipolare cu scăderea activității pompei de $\mathrm{Na} / \mathrm{K}$. Deoarece concentrațiile sodiului liber tind să fie egalate de cele ale calciului liber, activitatea scăzută a ATP-azei poate fi responsabilă pentru concentrațiile 
intracelulare mari de calciu găsite în celulele din sângele periferic al bolnavilor cu depresie. (Lenox şi Hahn, 2000).

La pacienții trataţi cu litiu, activitatea ATP-azei de $\mathrm{Na} / \mathrm{K}$ a crescut, fiind în concordanţă cu constatarea reducerii concentrației intracelulare de calciu şi de sodiu după tratament. Implicarea ATP-azei de $\mathrm{Na} / \mathrm{K}$ în reglarea concentraţiilor de litiu prin membrană este încă incertă (Lenox şi Hahn, 2000).

Litiul poate părăsi celula prin sistemul antiport $\mathrm{Na} / \mathrm{Li}$ (schimbătorul de $\mathrm{Na} / \mathrm{Na}$ sau $\mathrm{Li} / \mathrm{Li}$ ). Acesta poate transporta sodiu contra sodiu, litiu contra litiu şi mai ales sodiu contra litiu. A fost evidențiat în membrana eritrocitară, dar nu a fost descris încă şi la nivelul celulelor renale. Afinitatea pentru litiu este de 15-18 ori mai mare decât cea pentru sodiu. Pe faţa externă, concentrația de sodiu este mare şi transportul leagă sodiul pe care-l transportă în interiorul celulei. Aici, concentrația internă de sodiu este mai mică şi proteina leagă preferențial litiul, pe care îl transportă la exterior. Acest transport se realizează cu consum energetic şi este, probabil, o reacție secundară la un alt proces, deoarece altfel nu poate fi explicată necesitatea celulei de a efectua schimburi electroneutre (Timmer şi Sands, 1999).

Principalele proteine transportoare care participă la homeostazia litiului sunt canalele de sodiu şi transportul de litiu-sodiu. Aceleaşi mecanisme de transport funcționează şi la nivel renal în reabsorbția litiului de la nivelul tubului colector şi al segmentului proximal. Aproximativ $60 \%$ din litiul filtrat este reabsorbit în segmentul proximal prin intermediul proteinelor transportoare. Reabsorbția pasivă a litiului pe cale paracelulară este puțin probabilă (Timmer şi Sands, 1999), datorită potenţialului său electrochimic scăzut la nivelul segmentului proximal. Segmentul proximal nu prezintă o permeabilitate deosebită pentru litiu, aceasta fiind egală cu cea a sodiului, excluzând posibilitatea unui transport pasiv bazat pe permeabilitate crescută pentru litiu (Timmer şi Sands, 1999).

Reabsorbția pe cale transcelulară a litiului nu este pe deplin elucidată. Transportul prin membrana apicală se realizează prin intermediul schimbătorului de $\mathrm{Na} / \mathrm{H}$ şi prin cotransportorii dependenţi de sodiu. Ieşirea litiului din celulă în plasmă prin membrana bazolaterală nu se poate realiza pasiv datorită permeabilităţii scăzute a acesteia pentru ionii de litiu şi sodiu. Se presupune existența la nivelul membranei bazolaterale a unui transportor de tipul schimbătorului $\mathrm{Na} / \mathrm{Li}$. Analiza concentrațiilor intracelulare ale litiului şi sodiului la pacienții cu tulburări afective au condus la ipoteza că patogenia tulburărilor afective poate fi corelată cu disfuncționalităţi ale transportului prin membrana celulară. Litiul intervine în reglarea concentrațiilor intracelulare de sodiu şi calciu, acționând asupra proteinelor de transport. 


\section{Litiul şi activitatea electricã a membranei celulare}

Trei regiuni diferite ale sistemului nervos central al vertebratelor menţinute in vitro (mãduva spinãrii de broascã, scoarța cerebralã olfactivã şi hipocampul porcilor de guinea) pot fi utilizate pentru a investiga felul ĩn care $\mathrm{Li}^{+}$influențeazã potențialul de membranã, rezistența membranarã, potențialul de acțiune, potențialul sinaptic şi distribuirea trans-membranarã a $\mathrm{K}+$ ĩn neuroni şi celule gliale.

Ținând seama de acțiunea terapeuticã a Li+ în maniaco-depresie, un efort special a fost sã se determine concentrația pragului de sensibilitate pentru acțiunea $\mathrm{Li}+$ asupra parametrilor electro-membranari. S-a observat cã depolarizarea membranei este indusã de $\mathrm{Li}^{+}$atât neuronilor cât şi celulelor gliale, determinând o scãdere a amplitudinii potențialului de acțiune, o facilitare a potențialului postsinaptic excitator monosinaptic şi o depresie a reflexelor polisinaptice.

Rezistența membranarã a neuronilor nu este schimbatã. $\mathrm{Li}^{+}$induce de asemena o creştere a concentraţiei potasiului extracelular şi o scãdere a potasiului intracelular. Mai mult, în prezența $\mathrm{Li}^{+}$se observã o ĩncetinire a recuperãrii potenţialului membranar al neuronilor şi celulelor gliale şi a concentraţiei extracelulare a potasiului dupã stimularea repetitivã a sinapsei.

Pragul de sensibilitate al concentrației de $\mathrm{Li}^{+}$pentru efecte sale este sub 5 mmol/l în mãduva spinãrii de broascã şi sub $2 \mathrm{mmol} / 1$ în scoarţa cerebralã olfactivã şi hipocampul porcilor de guinea. Mecanismul de bazã pentru acțiunea $\mathrm{Li}^{+}$ar putea fi o interacțiune cu funcția de transport a pompei $\mathrm{Na}^{+} / \mathrm{K}^{+}$.

Pe lângã o posibilã acțiune asupra metabolismului neurotransmiţãtorilor şi a receptorilor lor, existã mai multe indicații cã $\mathrm{Li}^{+}$poate sã interacționeze cu distribuția şi transportul de potasiu şi sodiu în sistemul nervos central. Li+ determinã o scãdere a concentrației $\mathrm{K}^{+}$pe feliile de creier. Ullrich et all au descris o creştere a concentrației extracelulare de $\mathrm{K}^{+}$în cerebelul şobolanilor care au fost continuu trataţi cu $\mathrm{Li}^{+}$. Mai mult, Li + inhibã preluarea $\mathrm{K}+$ de cãtre feliile de creier dupã o perioadã de incubație anaerobã şi de asemenea preluarea $\mathrm{K}^{+}$în culturile primare de astrocite. Complementar acestor observații este interacțiunea $\mathrm{Li}^{+}$cu pompa electrogenã de $\mathrm{Na}^{+} / \mathrm{K}^{+}$, fapt demonstrat de scãderea sau blocarea hiperpolarizãrii membranei neuronale dupã stimularea repetitivã a vagului la şobolan sau la iepure, a nervului optic de amfibian, a receptorului de ĩntindere la racul de râu şi a aferenței primare a mãduvei spinãrii la broaşte. Ultimul efect a fost investigat în special folosind concentraţii mari de $\mathrm{Li}+$, dar a fost a observat şi în domeniul terapeutic.

Aplicarea de $\mathrm{LiCl}$ în soluția de perfuzie, atât prin ĩnlocuirea equimolarã a unei concentrații de $\mathrm{NaCl}$ cât şi prin adãugarea ei la salinitatea normalã, duce la creşterea concentrației extracelulare de $\mathrm{K}^{+}$. Mai multe experimente au demonstrat cã acele schimbãri de voltaj mãsurate cu electrozii sensibil la ionul de $\mathrm{K}^{+}$în prezența $\mathrm{Li}^{+}$au fost într-adevãr cauzate de o creştere a $\left[\mathrm{K}^{+}\right]_{\mathrm{e}} \cdot \mathrm{Li}^{+}$are de asemenea o influenţã asupra fazei de refacere a $\left[\mathrm{K}^{+}\right]_{\mathrm{e}}$ dupã stimularea sinapticã repetitivã. 
Li+ induce o depolarizare membranarã a motoneuronilor spinali la broascã şi a neuronilor scoarței cerebrale olfactive la porcii de guinea. Motoneuronii spinali de broascã nu au arãtat nici o o schimbare clarã a potențialului de membranã la 5 mmol 1 LiCl, pe când 15 mmol $1 \mathrm{LiCl}$ creeazã o depolarizare de $3,2 \mathrm{mV} \cdot \mathrm{Li}^{+}$are o acțiune rapidã, iar recuperarea membranei dupã depolarizarea indusã de $\mathrm{Li}^{+}$poate fi observatã în câteva minutele dupã spãlarea cu soluție normalã -Ringer. În neuronii scoarței cerebrale olfactive, o depolarizare membranarã clarã a fost mãsuratã. Aceastã depolarizare este dependentã de concentrație şi fluctueazã ĩntre 2,5 şi $5 \mathrm{mV}$ la 5 $\mathrm{mmol} / 1 \mathrm{Li}^{+}$, şi între 6 şi $8 \mathrm{mV}$ la $15 \mathrm{mmol} / \mathrm{L} \mathrm{Li}^{+}$.

În mãduva spinãrii, o hiperpolarizare membranarã post-tetanicã a motoneuronilor este observatã dupã stimularea repetitivã a rãdãcinii dorsale $(10-20 \mathrm{~Hz}$; 10-20 s). Este foarte posibil ca aceastã hiperpolarizare sã rezulte din activarea unei pompe electrogene de $\mathrm{Na}^{+} / \mathrm{K}^{+} .15 \mathrm{mmol} / 1 \mathrm{LiCl}$ reduce sau chiar aboleşte aceastã hiperpolarizarea membranarã post-tetanicã. În plus, se produce o depolarizare membranarã şi o creştere a potenţialelor sinaptice spontane. De asemenea, şi în scoarța cerebralã olfactivã se poate observa o schimbare în comportarea post-tetanicã a neuronilor indusã de $\mathrm{Li}^{+}$. În contrast $\mathrm{cu}$ aspectul uniform al hiperpolarizãrii posttetanice în motoneuronii de la broascã, la neuronii scoarței cerebrale olfactive se observã o variabilitate mult mai mare a fazele de recuperare post-tetanicã.

Efectele $\mathrm{Li}^{+}$pe celulele gliale au fost investigate folosind felii ale scoarței cerebrale olfactive. Acțiunea litiului are drept rezultat o depolarizare membranarã şi incetinirea fazei de recuperare a potenţialului de membranã dupã stimularea repetitivã. O depolarizare de $2,2 \pm 1 \mathrm{mV}$ a membranei se observã la $5 \mathrm{mmol} / 1 \mathrm{Li}^{+}$.

$\mathrm{S}$-a arãtat cã $15 \mathrm{mmol} / 1$ acel $\mathrm{Li}^{+}$reduce amploarea reflexelor polisinaptice şi sporeşte frecvenţa activitãţii sinaptice spontane în mãduva spinãrii izolatã de broascã. Ambele efecte sunt imitate de o creştere a concentrației de potasiului extracelular de la 3,6 la 4,6 mmol/1. Efectele litiului asupra CNS sunt datorate unei schimbãrii a homeostaziei potasiului care stã la baza unei depolarizãri membranare.

Efectele litiului asupra activitãţii electrice membranare şi distribuției ionlor de potasiu ĩn mãduva spinãrii la broascã, ĩn scoarța cerebralã olfactivã şi hipocampul porcilor de guinea este consecința unei interacțiuni a ionilor de $\mathrm{Li}^{+}$cu funcția de transport a pompei de $\mathrm{Na}^{+} / \mathrm{K}^{+}$(Grafe et all, 1983).

$\mathrm{Li}^{+}$poate avea 3 site-uri de acțiune asupra pompei de $\mathrm{Na}^{+} / \mathrm{K}^{+}$:

a) $\mathrm{Li}^{+}$poate concura $\mathrm{cu} \mathrm{K}^{+}$pentru o un site comun extracelular. Aceastã posibilitate este sprijinitã de argumentul cã preluarea intracelularã de $\mathrm{Li}+$ depinde de concentraţia extracelularã a $\mathrm{K}^{+}$.

b) influxul de Li+ în neuron poate sã scadã concentraţia liberã intracelularã de $\mathrm{Na}+$ şi în felul acesta sã aibã drept rezultat o stimulare redusã a pompei de $\mathrm{Na}^{+} / \mathrm{K}^{+}$.

c) o a treia posibilitate este ca $\mathrm{Li}^{+}$sã schimbe electrogenitatea pomei de $\mathrm{Na}^{+} / \mathrm{K}^{+}$ la o modalitate electroneutrã de pompare $\mathrm{K}+/ \mathrm{K}+$, aşa cum a sugerat Duhm. 


\section{Litiul şi ciclul fosfo-inositidic}

Mecanismul molecular de acțiune al litiului nu este cunoscut. Există mai multe ipoteze privind acțiunea litiului la nivel molecular. Fiecare ipoteză implică o enzimă țintă, asupra căreia litiul exercită o acțiune directă. Aceste enzime sunt exprimate pe suprafețe întinse, folosesc un ion metalic pentru cataliză şi sunt inhibate de către litiu într-o manieră necompetitivă prin înlocuirea unui cation bivalent (Klei şi Phiel, 2001).

Pentru a putea fi considerată țintă directă a litiului, o enzimă trebuie să îndeplinească o serie de condiții (Klein şi Phiel, 2001):

$>$ Să fie sensibilă numai la acţiunea directă a litiului şi nu a altor cationi monovalenți;

$>$ Să fie sensibilă in vivo la concentraţii fiziologice ale litiului;

$>$ Mutațiile „loss of function” ale genei ce codifică enzima respectivă trebuie să fie fenocopiate de expunerea la litiu;

$>$ Inhibitorii alternativi ai enzimei trebuie să reproducă acțiunea litiului;

$>$ Efectul litiului asupra enzimei trebuie să fie reversibil prin anumite modulări ale componentelor în aval de țintă;

$>\mathrm{O}$ formă rezistentă a moleculei la acțiunea litiului trebuie să inhibe in vivo efectul $\mathrm{Li}^{+}$.

Una dintre enzimele țintă este inozitol monofosfataza. Aceastã enzima este implicată în regenerarea inozitolului (Klein şi Phiel, 2001). Monofosfataza ocupă o poziție cheie în mecanismul homeostatic al inozitolului deoarece se află la confluența a două căi distincte implicate în menținerea nivelelor intracelulare de inozitol: refacerea inozitolului datorită scindării activate a inozitidelor şi o cale separată pentru sinteza de novo a inozitolului din glucoză (Fig. 3).

Sărurile de litiu inhibă necompetitiv enzimele ceea ce înseamnă că se leagă numai de complexul enzimă-substrat (Berridge et all, 1989).

Efectul net al inhibării metabolismului inozitol fosfaţilor constă în suprimarea reciclării inozitolului datorită hidrolizei inozitol fosfaţilor intermediari. In timpul tratamentului cronic cu săruri de litiu are loc o acumulare a trei inozitol monofosfaţi (inozitol 1 fosfat, inozitol 3 fosfat, inozitol 4 fosfat), a inozitol 1,4 bifosfat şi a inozitol 1,3,4 trifosfat (Einat et all, 1998).

Deoarece pentru acțiunea de stabilizare a maladiei este necesită o perioadă de lag şi nu se produce revenirea acesteia imediat după întreruperea tratamentului, se crede că mecanismul de acțiune al ionului de litiu implică efecte pe termen lung (Nonaka et all, 1998).

Litiul inhibă inzitol monofosfataza, sistând refacerea resurselor celulare de inozitol. Inozitolul este precursor în sinteza fosfatidil-inozitol bifosfatului care este un element cheie în desfăşurarea căii de semnalizare a fosfoinozitidelor.

Epuizarea resurselor interne de inozitol determinată de acțiunea litiului conduce, în final, la blocarea semnalizării pe această cale (Klein şi Phiel, 2001). 


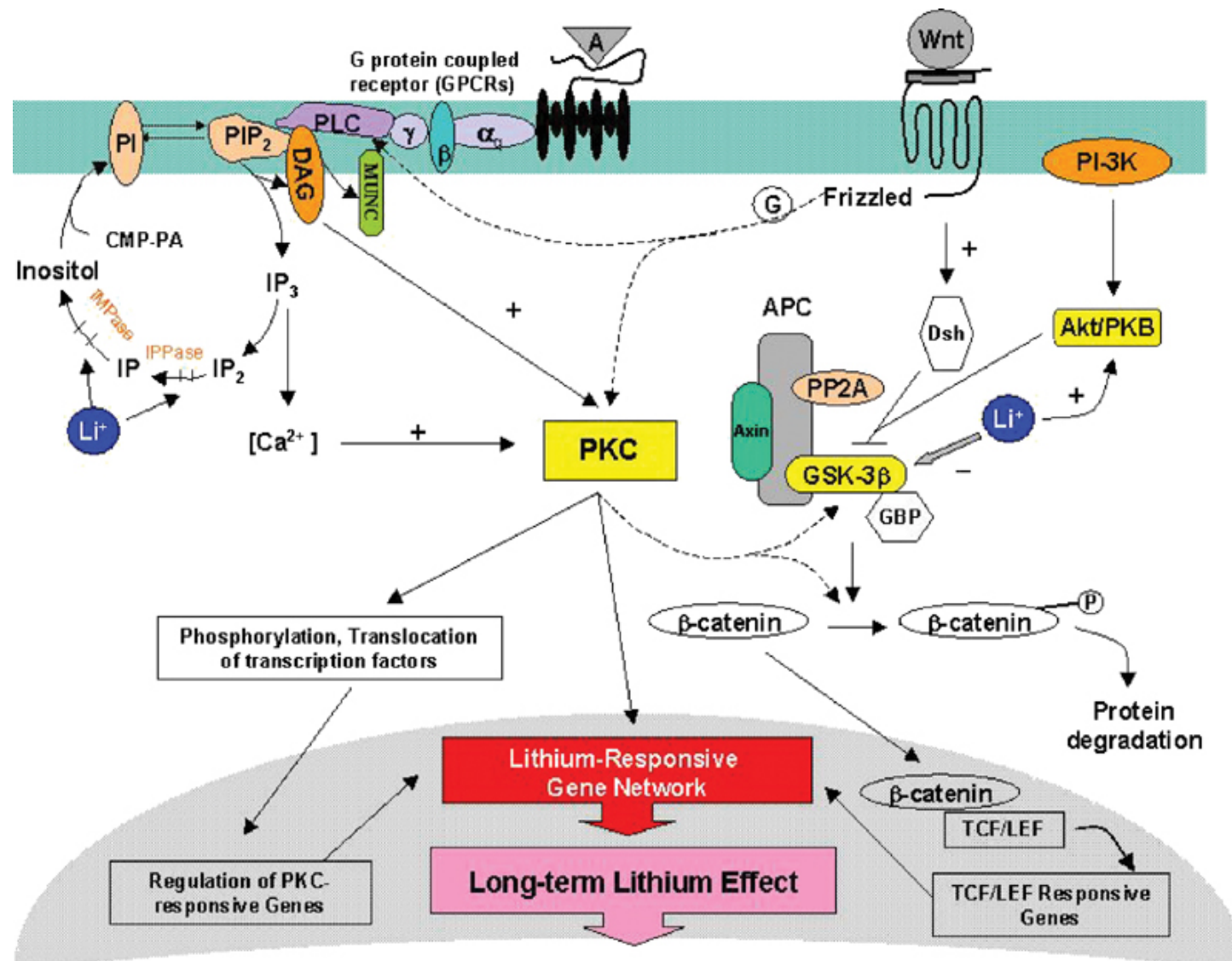

\section{Synaptic Function Neuroplasticity Neuroprotection}

Figura 3. Mecanismele celulare ale acțiunii litiului la nivel celular

\section{Localizarea şi structura genei inozitol monofosfatazei}

La om există două gene responsabile cu sinteza inozitol monofosfatazei IMPA1 şi IMPA2 (Detera-Wadleigh, 2001):

1. IMPA1 a fost clonată în 1992 şi este localizată pe cromozomul 8. Are o mărime de $25 \mathrm{kpb}$ şi prezintă nouă exoni.

2. IMPA2 are o lungime de $27 \mathrm{Kpb}$ şi se află pe brațul scurt al cromozomului 18. La fel ca şi IMPA1, prezintă nouă exoni.

Structura inozitol monofosfatazei: Inozitol monofosfataza este o proteină dimerică alcătuită din lanțuri polipeptidice identice formate din 273 de resturi de aminoacizi. Enzima prezintă două situsuri catalitice active de legare a unui ion metalic. Fiecare unitate a homodimerului este alcătuită dintr-o succesiune alternativă de structuri $\beta$ pliate şi perechi de $\alpha$ helixuri dispuse în cinci straturi. Perechea centrală de $\alpha$ helixuri este flancată de două structuri $\beta$ pliate antiparalele, alcătuind miezul enzimei mărginit de două perechi de $\alpha^{*} \beta^{*} \alpha^{*} \beta * \alpha$. 


\section{Calea de semnalizare a fosfoinozitidelor}

Legarea ligandului la nivelul recptorilor căii duce la activarea proteinei $\mathrm{G}$, care activează fosfolipaza $\mathrm{C}_{\beta}$ ce hidrolizează fosfatidilinozitol bifosfatul $\left(\mathrm{PIP}_{2}\right)$.

Fosfatidilinozitol bifosfatul este localizat în stratul intern al membranei plasmatice. Hidroliza acestuia conduce la formarea a doi mesageri secundari: diacilglicerolul (DAG) şi inozitoltrifosfatul ( $\left.\mathrm{IP}_{3}\right)$.

Inozitol trifosfatul este o moleculă hidrosolubilă, care părăseşte membrana şi se leagă la nivelul canalelor de calciu din reticolul endoplasmatic. Prin această legare induce activarea canalelor care activează calciu în citosol. Reglarea eliberării de calciu se face prin feedback pozitiv, prin care ionii de calciu eliberaţi în citosol se pot lega la canal, crescând viteza de eliberare. Există două mecanisme de stopare a eliberării de calciu:

$>\quad$ Calciul intrat în citosol este rapid pompat afară din celulă;

$>\quad$ Inozitol trifosfatul este defosforilat rapid de către fosfataze la inozitol.

La acest nivel acționează şi inozitol monofosfataza, catalizând transformarea inozitol-monofosfatului în inozitol.

Diacilglicerolul prezintă două roluri distincte în semnalizare:

$>\quad$ Este clivat în continuare la acid arahidonic, care poate acționa ca mesager sau poate fi utilizat ca precursor în sinteza eicosanoidelor;

$>\quad$ Fosforilează o serin-treonin kinază numită protein kinaza C (PKC).

Activitatea PKC depinde de nivelurile crescute de calciu induse de inozitol trifosfat. PKC este localizată în special în creier, unde intervine în reglarea excitabilității membranei plasmatice neuronale prin fosforilarea canalelor ionice.

Protein kinaza $\mathrm{C}$ creşte viteza de transcriere a anumitor gene, acționând pe două căii:

$>$ Declanşează o reacție de fosforilare în lanț, care se finalizează cu activarea unor factori transcripționali;

$>\quad$ Fosforilează o proteină inhibitoare, eliberând un factor transcripțional citoplasmatic, care pătrunde în nucleu şi stimulează transcrierea anumitor gene.

Acțiunea litiului asupra căii de semnalizare a fosfoinozitidelor

Litiul blochează calea de semnalizare a fosfoinozitidelor prin inhibarea inozitol monofosfatazei, cu următoarele consecințe:

1. creşterea cantităţii de inozitol monofosfat;

2. scăderea cantităţii endogene de inozitol;

3. scăderea sintezei de fosfatidilinozitol bifosfat;

4. blocarea semnalizării prin intermediul $\mathrm{DAG}$ şi $\mathrm{IP}_{3}$;

5. blocarea activității PKC;

6. lipsa activării sau eliberării factorilor transcripționali.

7. blocarea transcrierii genelor.

Litiul este un inhibitor necompetitiv al al IMP-azei, eficacitatea inhibiției crescând direct proporțional cu concentrația substratului (Klein şi Phiel, 2001). Cu cât 
concentrația este mai mare, cu atât efectul litiului este mai puternic. Aceasta are drept consecință faptul că efectele inhibitorii ale litiului nu pot fi înlăturate prin creşterea concentrației substratului. Caracterul de inhibitor necompetitiv explică şi lipsa efectelor tratamentului cu litiu asupra stării psihice a subiecților sănătoşi (Klein şi Phiel, 2001).

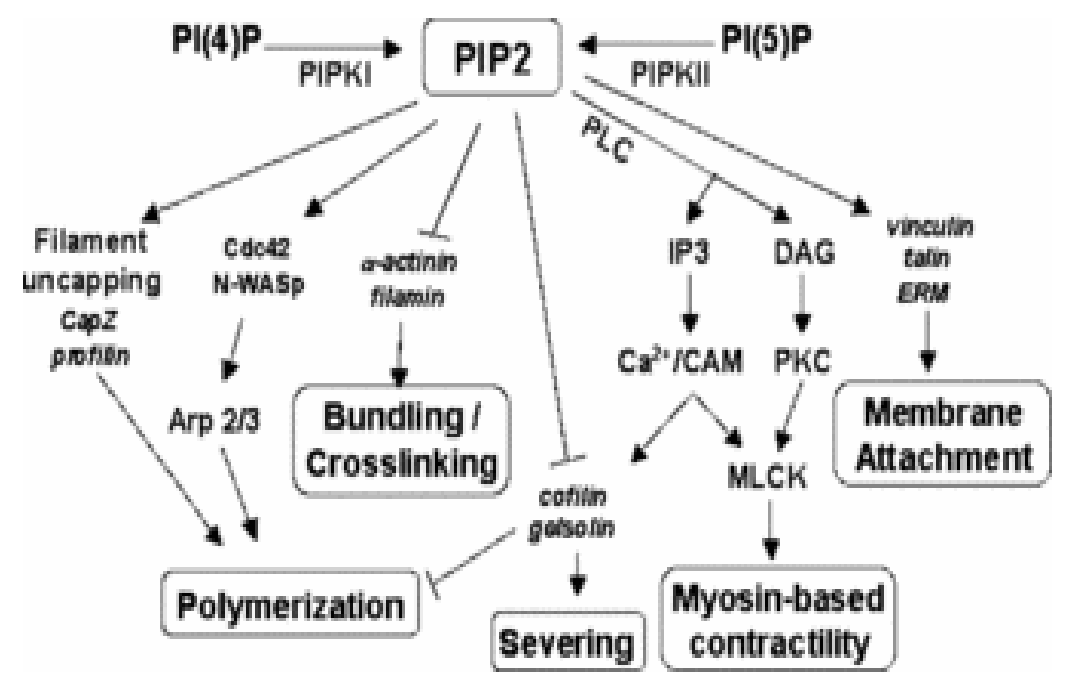

Figura 4. Calea de semnalizare PIP2

\section{Argumente ce susțin inozitol monofosfataza ca enzimă țintă pentru acțiunea}

litiului.

Enzima este sensibilă la litiu in vivo (Klein şi phiel, 2001).

Efectul litiului este reversibil. Experimental s-a observat că injectarea de mioinozitol la embrionii de găină anulează efectul litiului de inhibare a vasculogenezei (Giles şi Bannigam, 1999). De asemenea, coinjecția de litiu cu inozitol previne apariția efectelor teratogene la embrionii de Xenopus (Klein şi Phiel, 2001).

Expunerea embrionilor de Xenopus laevis la doze teratogene de litiu inhibă in vivo inozitol monofosfataza (Klein şi Phiel, 2001). La Dictyostellium, rezerva de inozitol scade cu 20\% în urma aceluiaşi tratament (Klein şi Phiel, 2001).

Litiul în doze terapeutice poate determina, la mamifere, scăderea concentraţiilor de inozitol în anumite teritorii din creier foarte sensibile la inhibarea inozitol monofosfatazei (Klein şi Phiel, 2001).

Argumnte împotriva inozitol monofosfatazei ca enzimă țintă

În pofida rezultatelor experimentale care susţin ipoteza, inhibiţia inozitol monofosfatazei nu este suficientă pentru a explica efectele induse de litiu în dezvoltare (Klein şi Melton, 1996).

Bifosfonaţii sunt inhibitori alternativi ai inozitol monofosfatazei de o mie de ori mai puternici decât litiul. Deşi inactivează complet inozitol monofosfataza in vivo bifosfonații nu induc dorsalizarea embrionilor de Xenopus, spre deosebire de litiu. 
Mutația „loss of function” a fosfolipazei C blochează calea de semnalizare a fosfoinozitidelor fără a induce efectele provocate de litiu asupra dezvoltării la Dictiostellium (Klein şi Phiel, 2001)

La mamifere, concentraţiile terapeutice de litiu nu produc scăderea cantităţii de inozitol. Scăderea concentrației inozitolului, fosfatidilinozitol bifosfatului şi a inozitol trifosfatului se observă doar la administrarea de doze toxice.

\section{Alte fosfomonoesteraze inhibate de litiu.}

Prin analiza comparativă a structurilor terțiare ale unor fosfomonoesteraze, a fost evidențiată o secvenţă consens implicată în legarea ionului metalic. Acest domeniu are rol în cataliză şi la nivelul său are loc legarea ionului de litiu. Secvența a fost identificată iniţial la inozitol monofosfatază, inozitol polifosfat 1-fosfatază (IPP-aza) şi fructozo 1,6 bifosfatază, ulterior fiind descoperită şi la alte fosfomonoesteraze: Hal2p din drojdii, SAL 1 din plante superioare, CysQ din bacterii sau bifosfat 3 'nucleotidazele de la mamifere (Klein şi Phiel, 2001).

Existența regiunii consens demonstrază originea comună a acestor enzime. Toate aceste enzime sunt sensibile la acțiunea litiului.

Gena pentru inozitol polifosfat 1-fosfatază umană a fost clonată în 1992 şi este localizată pe brațul lung al cromozomului 2 în regiunea 2p32. Gena are o lungime de $25 \mathrm{kpb}$ şi prezintă 6 exoni. IPP-aza catalizează eliberarea unei grupări fosfat din inozitol trifosfat sau din inozitol bifosfat (Klein şi Phiel, 2001).

Acțiunea inhibitoare a enzimei a fost pusă în evidență la nivelul joncțiunilor neuromusculare la Drosophila. Efectele expunerii la litiu fenocopiază mutaţia genei pentru IPP-ază, amândouă conducând la anomalii în funcționarea veziculelor sinaptice. Embrionii mutanți sunt viabili, demonstrând existența unor căii alternative compensatoare care reglează cantitatea de inozitol disponibilă din celulă.

HAL2 a fost identificată la Saccharomice cerevisiae. Supraexprimarea genei conferă rezistență la salinități ridicate. HAL2 îndepărtează o grupare 3'-P de la adenozin 3', 5' bifosfat. Ea este inhibată de concentraţii foarte mice de litiu, ceea ce conduce la acumularea în celulă a adenozin bifosfatului, care va bloca sulfotransferazele şi enzimele cu rol în procesarea ARN (Klein şi Phiel, 2001).

Bifosfat 3'-nucleotidaza acționează tot prin intermediul adenozin bifosfatului; este dependentă de magneziu şi este inhibată necompetitiv de către litiu). Se presupune că inactivarea enzimei ar sta la baza diabetului insipid nefrogen produs de litiu.

Fosfomonoesterazele catalizează diverse căi metabolice, în principal calea de semnalizare a fosfoinozitidelor, gluconeogeneza, reglarea toleranței la sare şi procesarea ARN. Implicarea fosfomonoesterazelor în toate aceste căi metabolice explică multiplele efecte ale litiului. 


\section{Litiul şi GSK-3ß}

Tratamentul cu litiu produce schimbări similare activării ectopice a căii de semnalizare Wnt (Klein şi Melton, 1996; Klein şi al., 1997; Klein şi Phiel, 2001). Enzima considerată ca țintă a acțiunii litiului este glicogen sintetaz-kinaza $3 \beta$ (GSK$3 \beta$ ). Litiul inhibă direct enzima in vivo şi in vitro.

Calea de semnalizare Wnt este implicată în formarea mezodermului la vertebrate, inducția neurală şi în modelul de formare al membrelor. Componentele căii de semnalizare sunt: ligandul Wnt, receptorul Frizzled şi mediatorii intracelulari: dishevelled, GSK-3 $\beta$ şi $\beta$-catenin (Hedgepeth et all, 1997).

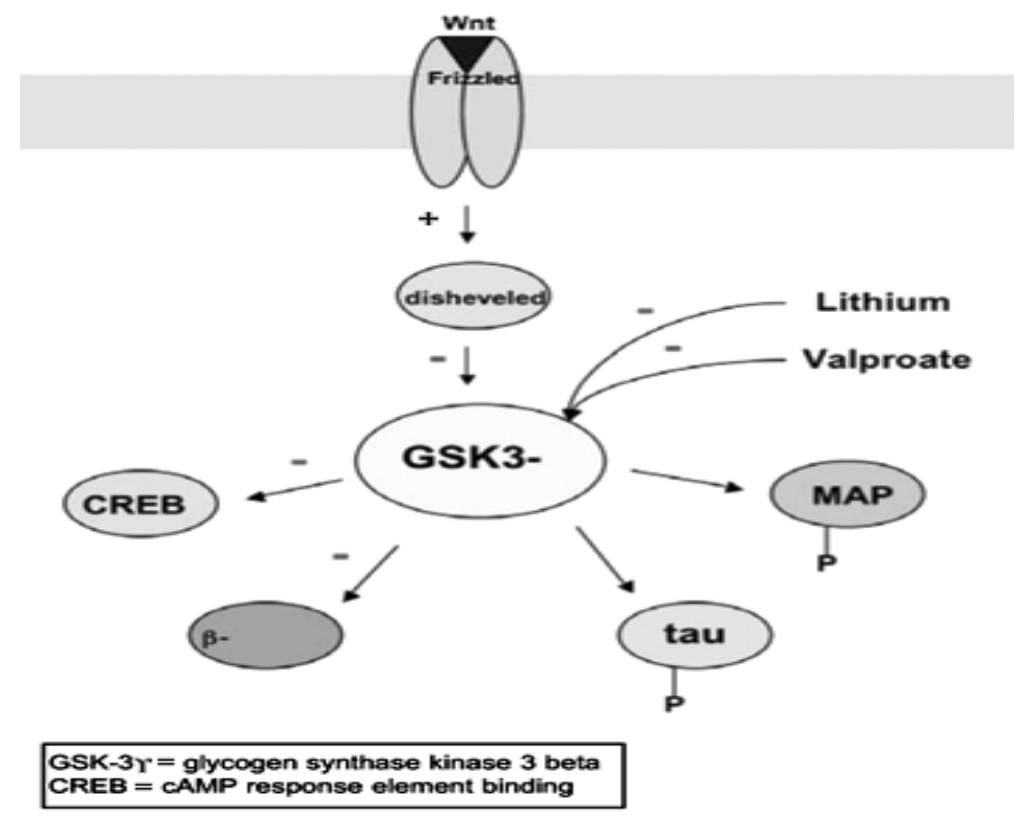

Figura 5. Calea de semnalizare Wnt

Există mai multe gene Wnt care codifică proteine semnal extracelulare bogate în cisteină. De exemplu gena Wnt7A este implicată în remodelarea axonală prin creşterea concentraţiei de sinapsin I în neuronii cerebelului. (Williams şi Harwood, 2000).

Frizzled este receptorul căii. Legătura dintre recptorii Frizzled şi calea de semnalizare Wnt a fost pusă în evidență la Drosophila. Receptorul este format din şapte domenii transmembranare, similar receptorilor cuplați cu proteina G, cu care însă nu prezintă omologie de secvență. Activarea receptorilor Frizzled conduce la activarea Dishevelled.

Dishevelled este activată prin fosforilarea resturilor de serină şi treonină, enzima responsabilă de activare fiind necunoscută.

GSK-3 $\beta$ (Zeste-white sau Shaggy) este o serin-treonin kinază componentă a căii de semnalizare Wnt. Prezintă un domeniu catalitic specific acestor kinaze, legat de o 
regiune neobişnuit de bogată în glicină, serină şi alanină. Gena se află pe braţul lung al cromozomului 3, în regiunea q13.3.

Gena Shaggy de la Drosophila are transcripți multipli generați prin splicing alternativ. În urma acestui proces, rezultă cinci proteine diferite. Activarea căii Wnt inhibă activitatea GSK-3 $\beta$ care nu mai poate fosforila $\beta$-catenina.

Armadillo ( $\beta$-catenina) prezintă două funcții:

$>$ este o proteină asociată cu domeniul citoplasmatic al caderinelor E şi mediază interacțiunea acestora cu filamentele de actină, participând la adeziunea celulară;

$>$ se află liber în citoplasmă, participând la calea de semnalizare Wnt.

Armadillo prezintă un domeniu N -terminal omolog în proporție de $43 \% \mathrm{cu}$ plakoglobina umană, 13 repetiții centrale de 42 de aminoacizi, identice în proporție de $70 \%$ cu plakoglobina şi un domeniu N-terminal bogat în glicină şi prolină în proporție de $36 \%$ identic cu plakoglobina.

$\beta$-catenin induce formarea axelor la embrionii de Xenopus prin intermediul factorului transcripțional XTcf - 3 (Pangolin).

Pangolin este un factor transcripțional cu domeniu HMG implicat în semnalizarea Wnt. Pangolin şi omologii săi de la vertebrate interacţionează cu Armadillo (ú-catenin) şi sunt transportaţi împreună cu acesta în nucleu unde îşi exercită acțiunea.

APC este o proteină supresoare tumorală, a cărei mutaţie determină apariţia de numeroşi polipi de-a lungul colonului. În timp, aceşti polipi se malignizează. Proteina normală se leagă de $\beta$-catenin, fiind implicată în calea Wnt.

Axin este o proteină care se leagă de $\beta$-catenin pentru a bloca semnalizarea Wnt. În lipsa ligandului, GSK-3 $\beta$ este activă şi fosforilează Axin, care fosforilată leagă $\beta$ catenin într-un complex Axin-GSK-3 $\beta$. La nivelul acestui complex, $\beta$-catenin este fosforilată de către GSK-3 $\beta$, devenind ținta degradării. În acest caz, factorii transcripționali de tip Pangolin sunt acetilați şi asociaţi cu corepresorul Grucho.

În prezenţa ligandului, receptorii Frizzled sunt activaţi şi vor activa Dishevelled. GSK-3 $\beta$ este inactivată şi PP2A (protein phosphatase $2 A$ ) defosforilează Axin, care, defosforilat, nu mai are capacitatea de legare a $\beta$-catenin, ce nu va mai fi deci fosforilată. $\beta$-catenin se va acumula în citoplasmă, va interfera cu acetilarea factorilor transcripționali din familia Tcf/Lef şi va media desprinderea de corepresorul Grucho (Klein şi al., 1997).

Litiul blochează GSK-3 $\beta$, cauzând efecte similare stimulării Wnt. Blocarea GSK-3 $\beta$ duce la creşterea concentraţiei citoplasmatice de $\beta$-catenin şi la activarea transcrierii genelor. 


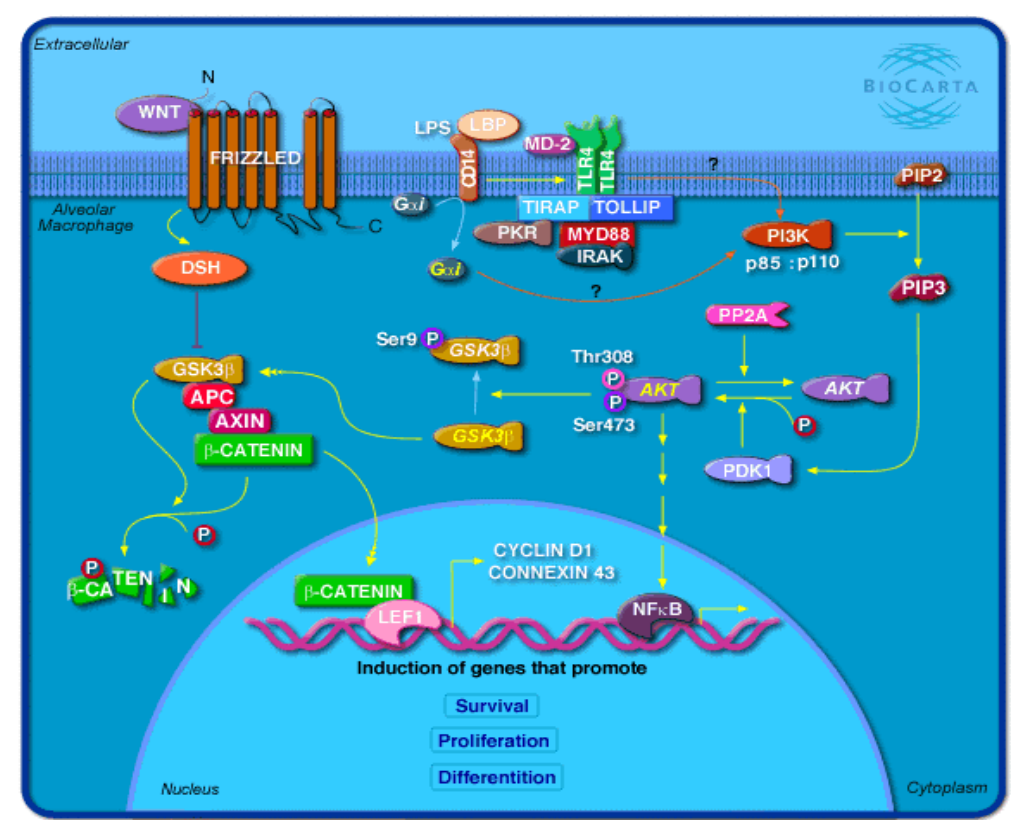

Figura 6. Acțiunea litiului la nivel celular

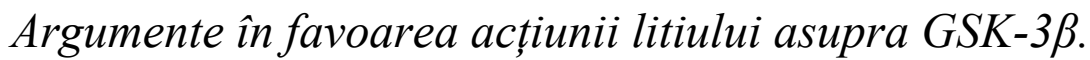

Litiul inhibă activitatea GSK-3 $\beta$ in vivo şi in vitro în dozele incluse în intervalul terapeutic al psihozelor bipolare. Clorura de litiu (doză de $2 \mathrm{mM}$ ) şi acetatul de litiu reduc activitatea GSK-3 $\beta$ la jumătate. Aceste rezultate demonstrează că litiul este unicul cation monovalent capabil să inhibe activitatea GSK-3 $\beta$ in vitro.

Litiul este un inhibitor necompetitiv al GSK-3 $\beta$ raportat la substrat, dar competitiv, raportat la magneziu. Litiul îşi exercită efectele asupra GSK-3 $\beta$ provenită de la specii diferite. Expunerea culturilor de celule epiteliale mamaliene precum şi a ovocitelor şi embrionilor de Xenopus sau arici de mare la litiu a determinat acumularea de - $\beta$-catrenin urmată de translocarea acesteia în nucleu şi activarea căii de semnalizare Wnt, ceea ce determină dorsalizarea embrionilor.

Oinjectarea de mio-inozitol cu litiu previne dorsalizarea embrionilor de Xenopus, ceea ce evidențiază posibilitatea implicării inozitolului în activarea indirectă a GSK-3ß (Klein şi Melton, 1996).

Inhibitori alternativi ai GSK-3 $\beta$ precum GBP (GSK-3 binding protein) inhibă fosforilarea proteinei tau şi determină dorsalizarea embrionilor de Xenopus, efecte identice $\mathrm{cu}$ cele produse de administrarea litiului. Un alt inhibitor al GSK-3 $\beta$ sunt fragmentele de Axin. Inhibarea activității enzimatice prin legarea fragmentelor de Axin conduce la efecte identice cu cele ale acțiunii litiului (Klein şi Phiel, 2001).

Toate aceste rezultate au demonstrat că GSK-3 $\beta$ reprezintă o țintă directă a acțiunii litiului. Prin acțiunea inhibitoare pe care o exercită asupra acesteia, litiul determină activarea căii de semnalizare Wnt soldată cu multiple efecte în dezvoltare. 


\section{Acțiunea litiului asupra altor căi de semnalizare}

$\mathrm{Au}$ fost avansate şi alte ipoteze pentru a explica mecanismul de acțiune al litiului, de exemplu, perturbarea fluxului ionic prin membrane sau inhibarea funcției proteinei G trimerice. Numeroase studii au demonstrat că litiul interferă cu transmiterea semnalului prin receptorii cuplați cu proteina G. Litiul acționează asupra căilor de semnalizare prin inhibarea proteinei $G$ sau a altor efectori implicați, cum sunt adenilat ciclaza, PKC, fosfolipaza C (hedgepeth şi colab, 1997; Phiel şi Klein, 2001).

\section{Acțiunea litiului asupra adenilat ciclazei}

Adenilat ciclaza este o componentă esențială a căii de semnalizare a AMPciclic, care este activată de subunitatea $\alpha$ a proteinei $\mathrm{G}$. Au fost identificate izoforme ale acestei enzime: sensibile la calmodulină sau insensibile la calmodulină. Administrarea cronică a litiului inhibă atât izoformele sensibile la calmodulină cât şi pe cele insensibile.

Litiul inhibă in vivo şi in vitro acumularea de AMPc. Animalele tratate cu litiu prezintă o scădere cu $60 \%$ a cantităţii de AMPc formată ca răspuns la stimularea receptorilor cuplați cu proteina $\mathrm{G}$ de către vasopresină sau $\mathrm{ADH}$. Activitatea fosfodiesterazei AMPc şi conținutul de ATP în animalele tratate cu litiu sunt similare cu cele observate la animalele martor, ceea ce duce la concluzia specificităţii efectelor litiului (Timmer şi Sands, 1999).

Administrarea litiului în concentrație de 1-2 mM inhibă acumularea de AMPc în cortexul de şobolan ca răspuns la stimularea receptorilor de către nor epinefrină. Pentru a obține acelaşi efect în creierul uman este necesară o concentraţie de litiu de $5 \mathrm{mM}$. Expunerea prelungită la litiu produce un efect nesemnificativ asupra adenilat ciclazei stimulată de activarea receptorilor $\beta$-adrenergici. Însă în acest caz s-a observat o creștere a AMPc produsă la un nivel bazal. Analiza acestor observații a sugerat faptul că litiul inhibă adenilat ciclaza in vitro competitiv cu ionii de magneziu. Dar, ionii de magneziu nu previn efectele inhibitorii asupra acestei enzime ale tratamentului cronic cu litiu în creierul de şobolan. Efectele sunt reversibile prin creşterea concentraţiei de GTP (Lenox et all, 1998; Lenox şi Hahn, 2000).

Litiul acționează indirect asupra adenilat ciclazei prin intermediul unei proteine reglatoare care se leagă la subunitatea catalitică a acestei enzime. Se presupune că proteina reglatoare este proteina $\mathrm{G}_{\mathrm{s}}$ (Timmer şi Sands, 1999).

Dublul efect al litiului asupra acumulării AMPc depinde de starea de activare a receptorilor:

în condiţii bazale, sinteza AMPc este inhibată de proteina $G_{\alpha i}$. Litiul facilitează asamblarea conformației heterotrimerice inactive a $G_{i}$, ceea ce duce la creşterea sintezei de AMPc;

Activarea receptorilor cuplaţi cu proteina G stimulează disocierea proteinei heterodimerice $G \alpha_{s}$ care activează adenilat ciclaza şi creşte cantitatea de AMPc. Litiul reduce stimularea $G_{s}$ produsă de activarea receptorilor rezultând $o$ scădere a formării AMPc (Jope, 1998; Lenox şi Hahn, 2000). 


\section{Acțiunea litiului asupra protein Kinazei C}

Protein kinaza C (PKC) este implicată în calea de semnalizare a fosfoinozitidelor şi în declanşarea cascadei MAP-kinazelor. Au fost identificate peste 12 izoforme înrudite structural, dar diferite prin distribuția intracelulară şi regională în creier şi prin afinitatea pentru substrat.

PKC este prezentă în cantitate foarte mare în creier şi este localizată atât în elementul presinaptic cât şi în cel postsinaptic. PKC activă determină fosforilarea proteinei MARCKS (myristoylated alanine rich C-kinase substrate) şi translocarea acesteia de pe fața citoplasmatică pe fața externă a membranei. Proteina MARCKS, cel mai important substrat al PKC în creier, este implicată în transmiterea semnalului şi în procesele celulare asociate cu restructurarea citoscheletului. Această proteină complexă în stare nefosforilată leagă calmodulina şi realizează legătura dintre filamentele de actină şi membrana celulară.

Administrarea cronică a litiului la şobolan determină reducerea cu $30 \%$ a cantităţii de PKC $\alpha$ şi $\varepsilon$ din hipocamp. Administrarea de mio-inozitol blochează efectul litiului asupra PKC (Lenox şi Hahn, 2000).

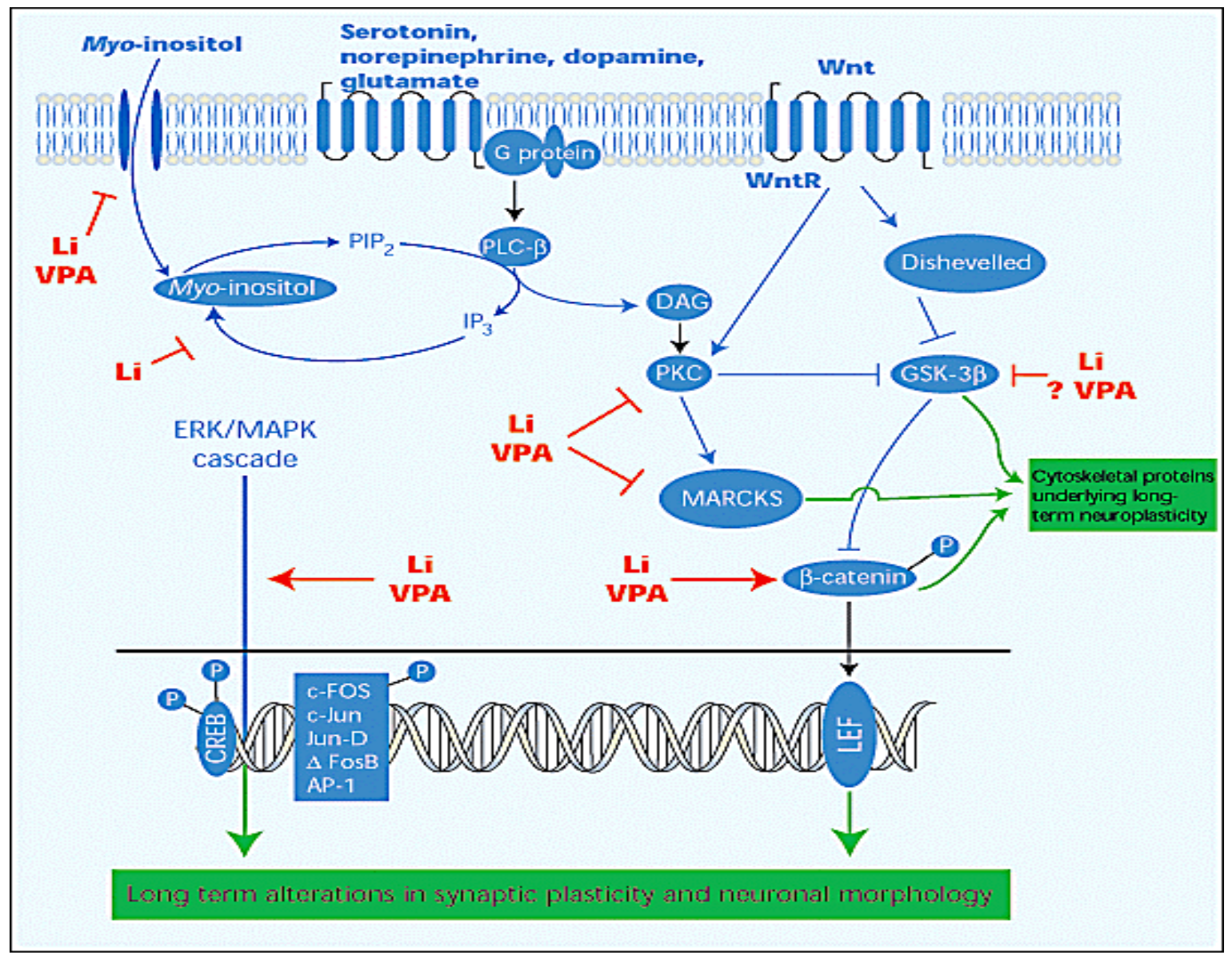

Figura 7. Acțiunea litiului la nivel celular 


\section{Implicarea litiului în neuroprotecție.}

A fost dovedită implicarea litiului în procese antiapoptotice (Detera-Wadleigh, 2001). Administrarea cronică de litiu protejează neuronii împotriva apoptozei induse de glutamat. Tratamentul cu litiu scade nivelul ARNm al genelor apoptotice p53 şi Bax şi creşte nivelul de ARNm al genei antiapoptotice Bcl2. La şoarece, creşterea expresiei genei Bcl2 în creier a fost indusă, de asemenea, de tratamentul de lungă durată cu litiu.

Litiul îşi realizează funcția antiapoptotică prin intermediul căii de semnalizare mediată de protein Kinaza B (Akt). Akt este o serin-treonin kinază şi o proto-oncogenă ce prezintă un domeniu de legare a fosfolipidelor utilizat pentru ancorarea acestora la membrana plasmatică.

Recrutarea Akt în membrană este detrminată de răspunsul la fosfatidilinozitol bifosfat şi fosfatidilinozitol trifosfat $\left(\mathrm{IP}_{3}\right)$. Akt este activată prin fosforilare de către fosfoinozitid-3 kinaza. Activarea fosforilativă a Akt este considerată un mecanism cheie în promovarea supraviețuirii celulare prin intermediul căii de semnalizare a fosfoinozitid-3 kinazei.

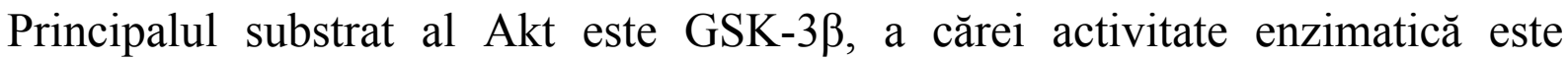
inhibată prin fosforilarea restului de serină din poziția 9, în timp ce activarea sa se realizează prin fosforilarea restului de tirozină din poziția 216. Exprimarea crescută a GSK-3 $\beta$ este responsabilă de declanşarea mecanismelor apoptotice. Mutaţia negativ dominantă a genei pentru GSK-3 $\beta$ blochează desfăşurarea acestora. În culturile de celule P12 activitatea GSK-3 $\beta$ este redusă semnificativ de NGF (NERVE GROW FACTOR), prin intermediul activării fosfoinozitid-3 kinazei. Tratamentul cronic cu litiu blochează mecanismele apoptotice prin activarea fosfoinozitid-3 kinazei urmate de fosforilarea Akt.

Mecanismele de neuroprotecție pot fi mediate şi prin intermediul căii de semnalizare Wnt. Gena Wnt1 activează factorul transcripțional nuclear NF-kb cu rol antiapoptotic în celulele P12. Litiul blochează desfăşurarea mecanismelor apoptotice prin inhibarea GSK-3 $\beta$ şi stabilizarea nivelurilor de $\beta$-catenin urmate de activarea căii de semnalizare Wnt. 


\section{Litiul şi neurotransmițãtorii}

Pentru a se stabili mecanismul de acțiune la nivelul sistemului nervos, a fost studiat efectul litiului asupra sistemelor de neurotransmițători.

Efectul litiului asupra sistemului dopaminergic.

Litiul scade capacitatea de transmitere a impulsului nervos la nivelul sinapselor dopaminergice prin acțiunea pe care o exercită asupra elementului presinaptic. La nivelul acestuia, acțiunea litiului se concretizează prin reducerea vitezei de sinteză a dopaminei şi creşterea turn-overului neuromediatorului (Lenox şi Hahn, 2000).

Receptorii dopaminergici sunt cuplați cu proteina $\mathrm{G}$, a căror hipersensibilizare a fost asociată cu stările maniacale. Experimental s-a demonstrat că hipersensibilizarea receptorilor indusă prin tratare cu haloperidol poate fi prevenită prin tratament cronic cu litiu. Tratamentul cu litiu previne şi auto-stimularea electrică intracraniană a şoarecilor tratați cu haloperidol.

Litiul acționează asupra receptorilor dopaminergici postsinaptici, sugerând existența unui situs de acțiune în aval de aceştia. S-a demonstrat că administrarea litiului după hipersensibilizarea receptorilor nu are nici un efect, dovedind o acțiune profilactică a acestuia.

\section{Efectul litiului asupra sistemului serotoninergic.}

Serotonina este indicată în reglarea comportamentului alimentar, sexual, a capacității de învățare şi a agresivității. Litiul determină creşterea transmiterii impulsului nervos la nivelul sinapselor serotoninergice prin scăderea capacității de recaptare a serotoninei în elementul presinaptic (Lenox şi Hahn, 2000).

\section{Efectul litiului asupra sistemului colinergic}

Disfuncțiile sistemului colinergic sunt implicate. în geneza tulburărilor afective şi în demențele de tip Alzheimer. Experimental s-a demonstrat că litiul induce creşterea transmiterii impulsului nervos la nivelul sinapselor colinergice din creierul de şobolan.

Litiul potențează efectele induse de pilocarpin (Lenox şi Hahn, 2000). Pilocarpinul este un agonist colinergic a cărui administrare produce hipotermie, catalepsie şi spasme. Efectul litiului poate fireversat prin administrare de mio-inozitol.

Litiul previne efectele administrării cronice de atropină, un agonist colinergic ce determină hipersensibilizarea receptorilor muscarinici (Lenox et all, 1998).

Efectul litiului asupra sistemului adrenergic.

Efectul litiului asupra sistemului adrenergic variază în funcție de timpul de administrare a dozei (Lenox et all, 1998).

Litiul induce în primele faze ale administrării creşterea recaptării şi sintezei adrenalinei la nivelul neuronului presinaptic. Cronicizarea tratamentului determină revenirea acestora la valorile anterioare administrării (Lenox şi Hahn, 2000). 
Rezultatele studiilor privind acțiunea litiului asupra receptorilor adrenergici nu sunt edificatoare. Majoritatea acestora confirmă implicarea litiului în creşterea pragului de stimulare a receptorilor $\beta$-adrenergici.

În doze unice, litiul determină scăderea sintezei de AMPc mediată de receptorul $\beta$-adrenergic prin inhibarea adenilat ciclazei. Tratamentul cronic cu litiu determină creșterea eliberării de adrenalină.

Efectul litiului asupra sistemului gabaergic.

Pacienții cu psihoză bipolară prezintă niveluri scăzute de GABA în sânge, niveluri reduse la normal în urma tratamentului cu litiu. S-a demonstrat că la nivelul hipocampusului are loc o creştere a numărului de receptori de tip $\mathrm{GABA}_{\mathrm{B}}$ ca urmare a administrării cronice de litiu (Lenox şi Hahn, 2000).

Efectul litiului asupra glutamatului.

Tratamentul de scurtă durată cu litiu creşte concentrarea glutamatului la nivelul fantei sinaptice prin inhibarea recaptării acestuia în sinaptozomi (Lenox şi Hahn, 2000). Spre deosebire de acesta, tratamentul cronic cu litiu creşte recaptarea glutamatului în neuronul presinaptic şi conduce la scăderea şi stabilizarea transmiterii sinaptice a mesajului nervos. Efectul administrării prelungite a litiului a fost dovedit şi de observaţia că litiul blochează excitotoxicitatea indusă de agoniştii glutamatului (Lenox şi Hahn, 2000).

Studii recente au propus implicarea litiului prin intermediul acțiunii sale asupra receptorilor NMDA în mecanisme de neuroprotecție şi antiapoptotice. Acțiunea neuroprotectoare a litiului ar putea fi datorată creşterii recaptării glutamatului la nivelul fantei sinaptice, urmată de scăderea concentrațiilor intracelulare de calciu. Recent s-a demonstrat implicarea litiului în reglarea proteinei Bcl-2 (B-cell lymphoma/leukemia 2).

\section{Efectele litiului în embriogeneză.}

Litiul induce efecte teratogene şi toxice în dezvoltarea diferitelor organisme. Are un spectru larg de acțiune, afectând dezvoltarea unor organisme foarte puțin înrudie filogenetic. Efectul litiului asupra dezvoltării eukariotelor a fost pus în evidență la Dictyostellium discoideum (Klein şi Phiel, 2001). La ariciul de mare, litiul induce vegetalizarea blastomerelor de la polul animal (Becchetti şi Whitaker, 1997). Ovulele nefertilizate de Lytechinus pictus au fost microinjectate cu clorură de litiu înainte de fertilizare. Aceasta a condus la blocarea dezvoltării embrionilor în stadiul de patru celule, împiedicând evoluția ulterioară a ciclului celular.

La vertebratele inferioare, cel mai spectaculos efect al litiului a fost pus în evidență la embrionii de Xenopus laevis. Sub acțiunea acestuia, are loc expansiunea mezodermului dorsal, ce va determina duplicarea axei dorsale. În cazurile extreme, se formează embrioni complet dorsalizați, cărora le lipsesc total țesuturile ventrale. (Klein şi Melton, 1996). 
La vertebratele superioare, efectele toxice ale litiului (clorurii de litiu) au fost demonstrate la embrionii de găină, la care rata mortalităţii a crescut simţitor după administrare (Giles şi Bannigan, 1998).

La mamifere, administrarea carbonatului de litiu în doze mai mari de $350 \mathrm{mg} /$ Kg-corp a determinat intoxicația severă a şoarecilor gestanți, manifestată prin hipotermie, rigiditate musculară şi comă (Giles şi Bannigan, 1997).

Clorura de litiu administrată la femelele gestante de şoarece afectează dimensiunile organelor descendenţilor (Messiha, 1986). Astfel, scade masa cerebrală concomitent cu întârzierea dezvoltării funcțiilor cerebrale, dimensiunile testiculelor la masculii nou născuți sunt scăzute, iar femelele au splina crescută.

Litiul stimulează activitatea alcool-dehidrogenazei hepatice şi a aldehiddehidrogenazei citoplasmatice hepatice la şoarecii expuţi prenatal şi postnatal la litiu (Messiha, 1993).

La om, în cazul femeilor însărcinate este necesară o atentă monitorizare şi ajustare a dozei terapeutice de carbonat de litiu pentru a fi evitate intoxicațiile (Timmer şi Sands, 1999; Schou, 1998; Austin şi Mitchell, 1998).

Litiul este excretat aproape exclusiv prin rinichi (Timmer şi Sands, 1999), clearance-ul renal al litiului reprezentând aproximativ $20 \%$ din fracția de filtrare glomerulară. Viteza de filtrare crește progresiv în timpul sarcinii, scăzând brusc la valori normale după naştere. Clearance-ul litiului urmează aceeaşi evoluție. Aceste observații au fost confirmate de experimente privind variaţia concentraţiei litiului în sânge la femelele gestante de şoarece (Ouznadji et all, 1999). Concentraţia de litiu scade treptat în timpul gestației, urmată de o creştere bruscă imediat după naştere. Au fost raportate cazuri în care femei însărcinate ce răspundeau bine la tratamentul cu litiu au dezvoltat intoxicații grave, survenite ca urmare a scăderii clearance-ului renal sau în urma administrării de diuretice (Schou, 1998).

\section{Influența litiului asupra ritmului circadian}

Ritmuri circadiene (zilnice) existã la toate eukariotele şi sunt dirijate de oscilatori biologici endogeni, auto-ĩntreținuţi; În absența unor intervenții de timp externe, ritmul se va derula cu o perioadã de aproape $24 \mathrm{~h}$.

Oscilatorul poate sã primeascã informaţii din mediu, care îi permit sã se sincronizeze cu ciclul noapte/zi ambiantal; Faza oscilatorului poate fi iniţiatã de un semnal luminos, iar la mai multe plante şi micro-organisme, ĩn aceastã iniţiere este implicat receptorul luminii albastre.

Perioada circadianã a activitãţii locomotorii a mamiferelor este controlatã de un ceas circadian localizat în nucleul suprachiasmatic hipotalamic. În condiții de sincronizare, toate ritmurile circadiene au periodicitate identicã dar au amplitudini şi peak-uri de timp diferite (acrofaze). 
Tratamentul cronic (dar nu şi acut) cu litiu prelungeşte perioada de oscilaţie la aproape toate sisteme biologice studiate, inclusiv specia umanã. Efectele litiului in condiții de sincronizare sunt specific variabile, cu întârzieri sau avansuri semnificative ale fazelor. Efectele depind de asemenea de momentul aplicației sale, astfel, administrarea hidroxibutiratului de litiului seara timp de 10 zile stabilizeazã ritmurile circadiene la şobolan, în contrast cu o administrare ĩn cursul dimineții ( Ikonomov şi Manji, 1999).

Baza biochimicã pentru ritmicitatea circadianã nu a fost ĩncã descrisã pentru orice organism, şi nici nu s-au gãsit explicații pentru mecanismul prin care oscilatorul primeşte informaţii din mediu prin semnalul luminos albastru.

Metabolismul fosfo inositolic a fost propus ca o componenta potenţialã atât a oscilatorului circadian cât şi a foto-transducției luminii albastre (Lakin-Thomas, 1993).

Experimentele într-un model circadian simplu (Neurospora crassa) nu au sprijinit rolul ciclului inozitol fosfatidic în efectele litiului pe ceasul circadian şi sincronizarea lui luminoasã (Ikonomov şi Manji, 1999).

Sindromul maniaco-depresiv şi durerea de cap cluster sunt tulburãri nervoase periodice; existã dovezi care leagã litiul şi de iniţierea altor procese ritmice normale.

Comportarea organismelor uni-şi pluricelulare este corelatã cu funcționarea ceasurilor biologice intrinseci. Într-adevãr, acțiunile litiului în schimbarea frecvențelor de oscilare a sistemelor fiziologice sugereazã cã ciclul fosfoinositidic este parte a mecanismului de reglare a ceasurilor biologice (Berridge et all, 1989).

O dovadã în favoarea participãrii metabolismului fosfo-inozitolului în mecanismul oscilatorului circadian vine de la efectele litiului asupra ritmurilor circadiene.

Tratamentul cronic cu $\mathrm{Li}+$ schimbã perioada ritmului la multe organisme, de la micro-organisme la mamifere. La majoritatea organismelor, perioada este mãritã, dar la altele este scurtatã.

Pânã acum s-au gãsit puține dovezi în favoarea rolului turnoverului fosfoinositidic ĩn transducerea semnalului luminos albastru. Semnalul luminos albastru activeazã proteine $G$ în plante şi ciuperci şi apoi activeazã o protein kinazã membranarã în plante.

Resetarea oscilatorului circadian indusã de lumina albã la mai Samanea implicã turnoverul fosfoinositidic. La ciuperca fibroasã Neurospora crassa, lumina albastrã induce resetarea oscilatorului prin implicarea unor protein kinaze, $\mathrm{a} \mathrm{Ca}^{2+}$ şi a fluxurilor ionice prin membrana plasmaticã.

Teste pe Neurospora crassa au arãtat cã:

1) Suplimentarea cu inozitol nu inverseazã efectele $\mathrm{Li}^{+}$asupra ritmului;

2) Depleția inozitolului la mutanta inozitol-necesarã nu imitã efectele $\mathrm{Li}^{+}$;

3) Depleția lipidelor inozitolice nu inhibã rãspunsul la luminã;

4) O razã de luminã care reiniţializeazã ritmul circadian nu crește nivelul de inozitol fosfați, inclusiv Ins(1,4,5) P3. 
Aceste informații fac puțin probabilã ca resetarea ritmului circadian indusã de lumina albastrã sã fie mediatã de inozitol (Lakin-Thomas, 1993).

Modificãri repetitive $\mathrm{cu}$ o periodicitate de aproximnativ 24 de ore sunt componente ale sistemului circadian. Acest sistem se gãseşte la organismele unicelulare, plante, animale şi om.

Ritmul circadian uman este bazat pe un numãr de oscilatoare de forțe variate care exercitã influențe reciproce. Principalul pacemaker ale acestui sistem multioscilant este nucleul suprachiasmatic.

Douã descoperiri recente sunt semnificative pentru abordãrile viitoare ale studiilor moleculare şi a mecanismelor celulare de acțiune ale litiului.

Mai întâi, neuronii disociaţi din nucleul suprachiasmatic conțin un ceas circadian şi exprimã un ritm circadian în activitatea de generare a impulsurilor.

Secundar, o combinaţie de studii de mutagenezã, de izolare a unor mutante cu aritmii comportamentale şi de geneticã molecularã a fost utilizate pentru a identifica un set de patru gene care reprezintã ,rotițe dințate” moleculare la nivel celular ale ceasului circadian la Drosophila.

Douã gene period (per) şi timeless (tim) oscileazã într-un ritm circadian atât ĩn nivelul ARNm cât şi ĩn nivelul proteic. Proteinele Per şi Tim formeazã un regulator cytosolic, trans-localizat în nucleul celular unde reprimã propria lor transcriere.

Alte douã proteine Clock şi Cycle formeazã de asemenea un regulator în nucleu. Acest regulator induce transcrierea $\mathrm{ARNm}$ a genelor per şi tim prin legare la secvențele E-box (5'-CACGTG-3') localizate în regiunea reglatorie a fiecãrei gene.

Declanşarea transcrierii genelor per şi tim poate fi reprimatã de cãtre dimerii formați de proteine lor proprii, generându-se astfel o buclã de reacție molecularã negativã de reglare a ceasului circadian.

Este demn de reținut cã un şoarece mutant aritmic are o singurã bazã schimbatã ĩn gena clock a mamiferelor, care este foarte omologã genei cycle de la Drosophila. Mamiferele au trei omologi ai genei per de la Drosophila cu conservarea secvențelor E-box în promotorii lor (Ikonomov şi Manji, 1999).

Ionii de litiu sunt chrono- activi din punct de vedere biologic . Ei influențeazã sistemul circadian modificând relațiile fazice şi lungind perioadele de oscilare.

În timpul maniaco-depresiei a fost observatã o varietate de disfuncții a episoadelor ritmului circadian. Importanţa factorilor circadieni şi ciclul somn-veghe în tulburarea bipolarã a fost recunoscutã de mulți ani (Ikonomov şi Manji, 1999).

Receptori hormonali nucleari funcționeazã ca proteine de legare la ADN liganddependente care traduc semnalele fiziologice/nutriționale în reglaj genetic. Disfuncția semnalizãrii receptorilor hormonali nucleari duce la multe dezordini în reproducere, inflamare, şi metabolism. Descifrarea funcției receptorilor nucleari de tip „orphan” este o realã provocare.

Rev-erb $\alpha$ a fost identificatã ca un regulator critic (şi țintã) al ritmurilor circadiene, un factor în tensiunea arterialã şi ĩn controlul al inflamãrii. 
Recent, douã rapoarte au demonstrat cã:

1) litiu mediazã reglarea stabilitãţii Rev-erba şi

2) E75 (orthologul Drosophilei pentru Rev-erb $\alpha$ uman) este bine legat de hem, şi funcționeazã ca un „senzor de gaz” prin interacțiunea cu CO/NO şi interferã cu repimarea DHR3 (orthologul Drosophilei pentru ROR $\alpha$ umanã: RAR-related orphan receptor).

Tratamentul cu litiu duce la sincronizarea oscilațiilor circadiene în celulele umane prin receptorul nuclear orphan Rev-erb $\alpha$, conform unui studiu recent. Acestã cale molecularã stã la baza efectelor litiului asupra ritmului circadian la persoanele cu tulburare bipolarã, condiție asociatã unor ritmuri circadiene aberante.

Rev-erb $\alpha$ este implicatã în planificarea evenimentelor biochimice circadiene în creier şi țesutul hepatic, şi regleazã $\mathrm{Bmal}_{1}$ şi la o mai micã intensitate expresia genei clock.

Rev-erb $\alpha$ este reglat direct de oscilatorul molecular: este activat de dimerul Bmal $_{1}$-clock, şi este reprimat de Period $1 / 2$ şi proteinele Cryptochrome $1 / 2$ (Ramakrishnan şi Muscat, 2006)

S-a stabilit cã Rev-erb $\alpha$ este parte a ceasului circadian şi cã litiul acționeazã asupra unei proteine cu rol în ritmul circadian, glicogen sintetaz kinaza (GSK) -3ß.

În ceasul molecular circadian al mamiferelor, factorii de transcriere BMAL1 şi CLOCK activeazã genele per şi cry ale ceasului, proteine al cãror feed-back inhiba în nucleu propria lor transcrierea.

Recent, biologii au descoperit alte bucle feedback negative paralelã care implicã receptorul nuclear Rev-erb $\alpha$. Dimerul BMAL1-CLOCK activeazã transcrierea Reverb $\alpha$, iar proteina Rev-erb $\alpha$ reprimã transcrierea de Bmall .

Rev-erb $\alpha$ are câteva site-uri potențiale pentru fosforilarea GSK-3 $\beta$.

Cercetãri anterioare au arãtat cã mutații ale omologului la Drosophila al GSK-3 $\beta$ lungeşte perioada ritmului circadian. Gsk $3 \mathrm{~b}$ a fost un candidat minunat pentru a explica cum semnale externe pot influența bucla informaționalã a Rev-erb $\alpha$.

Inhibarea GSK-3 $\beta$ prin siARN în celulele embrionare umane din rinichi duce la o pierdere aproape completã a proteinei Rev-erb $\alpha$, sugerând cã GSK-3 $\beta$ este necesarã pentru stabilizarea Rev-erb $\alpha$.

Tratând culturi cu concentrații mari de ser capabil sã sincronizeze oscilaţiile circadiane inhibã activitatea GSK-3 $\beta$ prin fosforilarea sa. Iarãşi scade expresia proteinei Rev-erb $\alpha$, se activeazã transcrierea Bmall, care începe ciclul expresiei ceasului circadian.

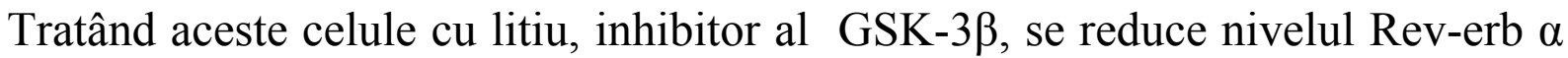
şi se activeazã transcrierea Bmall. Şocul nu poate sã iniţieze oscilațiile circadian în celule dacã Rev-erba este înlocuitã cu o formã mutantã rezistentã la degradare. 


\section{Litiul şi expresia genicã}

Mecanismul de acțiune al litiului ĩn tratamentul profilactic al tulburãrii bipolare este posibil sã fie cablat în ADN-ul genomic. În ciuda tuturor rapoartelor privind modul ĩ care expresia genelor individuale poate fi modulatã ca rãspuns la expunerea la litiu, nu existã ĩncã o strategie disponibilã pentru identificarea rețelei genomice receptive reglatã de litiu în creier. Multe studii s-au canalizat pe determinarea efectului litiului pe una sau câteva gene o datã, abordare ce nu este adecvatã pentru analize ale ĩntregului sistem de control organizat ca rețea genicã.

Expresia specificã a unei gene este controlatã de cis-regulatorul specific din succesiunea țintã ĩncorporatã în promotori şi de factori transcripționali înrudiţi cifraţi cu un set de gene reglatoare. Legãturile funcționale ale unei astfel de rețele de reglare genomicã includ elemente care expun interacțiuni multiple între produşii genelor reglate şi secvențele corespondente ale cis-regulatorului genomic. Astfel, identificarea rețelei de factorii de transcriere şi a genelor pe care le regleazã ca rãspuns la expunerea la litiu este importantã pentru a înțelege sensibilitatea biologicã a organismului la litiu şi caracteristicile profilactice ale acțiunii sale în creier.

Litiul induce scãderea proteinei MARCKS, însoțitã de inhibarea transcripţiei ARNm al MARCKS fãrã nici o dovadã pentru o schimbare în durata sa de ĩnjumãtãţire. Sinteza de ARN nascent pentru MARCKS şi activitatea promotorului Macs nu au fost semnificativ reduse în tratarea cronicã, dar nu şi acutã, cu litiu a celulelor din hipocamp. Ambele micşorãri au fost semnificativ sporite de activarea receptorilor cuplaţi la semnalizarea fosfatidil-inozitolicã.

S-a identificat o secvențã de promotor responsivã la litiu, localizatã în regiunea din amonte (-993/-713) a promotorului Macs. Promotorul mutant fãrã fragmentul respectiv nu mai este receptiv la litiul, administrat cronic, şi o activitate de promotor semnificativ mai redusã, sugerând cã litiu reprimã cuplarea factorului de transcriere la aceastã regiune. Pânã acum, nici un factor de transcriere receptiv la litiu direct obligat sã se ataşeze la aceastã regiunea nu a fost identificat.

În timp ce factorii de transcriere specifici care se leagã de elementul responsiv la litiu al promotorului (LRE) rãmân sã fie identificați, date curente sugereazã cã mecanismul prin care litiul, adminstrat cronic, reprimã transcrierea genei Macs prin:

a) inhibarea legãrii factorilor transcripționali la regiunea de reglare din ADN şi/sau expresia factorilor care interacționeazã cu LRE;

b) inhibarea funcției de activare a factorului de transcriere ce activeazã LRE;

c) separarea interacțiunii de coordonare între secvenţa distalã de activare şi secvenţa din miezul promotorului maşinãriei de transcriere.

Fragmentul litiu-receptiv -993/-713 conţine elementele enhancer şi de amplificare, necesare pentru a susține transcrierea optimã a genei Macs în celule. În timp ce un sit atipic Sp1, caracterizat prin prezența unei succesiuni GA, a fost identificat în regiunea - 
993/-713, un sit clasic Sp1 a fost depistat în mijlocul regiunii GC-rich box, lângã un segment Z-DNA din apropierea sitului de iniţiere a transcripției.

Prezența segmentului Z-DNA semnificã atât o schimbare conformaţionalã cât şi una compoziționalã ce influențeazã ĩnfãţişarea genomului, accesibilitatea elementelor activatoare cis şi declanşarea transcripției genice la nivelul promotorului. Promotorul genei macs duce lipsã de caseta tipicã TATA, şi fãrã caseta TATA, situri multiple Sp1 ale promotorului pot controla transcrierea genei Macs (Lenox şi Wang, 2003).

Un experiment recent de tip microarray a arãtat cã expresia a 37 de gene din cele 4132 de genele de la şobolan este modificatã în timpul tratamentului cronic cu litiu. Dacã aceste informaţii ar fi extrapolate la ĩntregul genom, ar putea fi 750 de gene reglate cu litiu. Oricum, majoritatea unor asemenea studii, folosind tehnici diferenţiale şi microarray, nu fac diferența între efectele directe şi cele indirecte pe care litiul le poate avea asupra genelor.

Folosirea cunoaşterii noastre privind o țintã cu valoare terapeuticã semnificativã MARCKS, pentru acțiunea cronicã a litiului în creier, pentru a identifica elementele litiureceptive care ar putea sã serveascã la integrarea genelor litiu-receptive ĩntr-o rețea de reglare este provocatoare şi interesantã.

Recent, utilizând perturbãri limitate ale expresiei genice şi tehnici microarray, se pot mima condiții fiziologice prin care se permite studiul acestora farã interevenții majore de tip superexprimare transgenicã sau utilizarea animalelor knockout. Prin astfel de studii se poate modula expresia unei singure gene, folosind tehnici de tipul interferențã ARN (ARNi). Odatã tulburate sistemele genomice, ele se aflã într-o starea nouã de regim staționar, nivelele de expresie genicã fiind mãsurate prin tehnici microarray sau Taqman PCR şi se comparã cu cele de referințã. Rezultatele sunt prezentate ca o rețea reglatã a interacțiunilor genetice.

Aceastã metoda are ĩnsã numeroase lipsuri şi o eficiența nesatisfãcãtoare deoarece nu furnizeazã dovezi directe ale unor interacțiuni in vivo ĩntre factorii de transcriere şi elementele lor cis-reglatoare de la nivel genomic.

Pentru a rãspunde acestor obstacole, o nouã tehnologie numitã ChIp-chip a fost dezvoltatã, în care imunoprecipitarea cromatinei (chIp) a fost cuplatã cu tehnica microarray (chip) pentru a accelera detectarea interacțiunilor genome-proteine timp real şi în spațiu real. Folosind tehnica chIp-chip, a fost realizatã la drojdie, cartarea siturilor de legare la ADN a factorilor de transcriere (STE12, GAL4, RAP1, SCB, MCB, MCM1, SFF, şi SW15). Aceastã tehnicã a fost extinsã cu succes la genomul uman, unde au fost cartate siturile de legare la ADN a factorilor de transcriere E2F şi GATA-1 (Lenox şi Wang, 2003).

O rețea de gene litiu-receptive oferã posibilitatea de a defini o cale asociatã cu efectele profilactice pe termen lung ale litiului, distinctã de cea a efectelor sale secundare, ceea ce are premise pentru descoperirea unor noi agenți terapeutici mai eficienți ĩn stabilizarea dispoziției pacienților cu tulburãri bipolare. 
Recent, o astfel de rețea de gene care dirijeazã evenimente specifice de dezvoltare a fost identificatã în dezvoltarea embrionului ariciului de mare. Acestã rețea furnizeazã un model euristic pentru conceperea unei rețele genice litiu-receptive.

Deşi cromozom imunoprecipitarea a plecat de la anticorpi pentru factorii de transcriere litiu-receptiv cunoscuţi, ca de exemplu AP-1 CREB, Nf-kb, LEF TCF, aceşti factori de transcriere sunt mult prea generali şi cu o expresie genicã mult mai amplã decât cea necesarã pentru acțiunea terapeuticã a litiului. Prin urmare, identificarea unor factori de transcriere litiu-receptiv sau elemente din promotor de la ținte mult mai specifice, ca de exemplu gena Macs este de dorit (Lenox şi Wang, 2003).

Litiul determinã o creştere timp- şi concentraţie-dependentã a legãrii la ADN a elementului de rãspunsul 12-O-tetradecanoilforbol 13-acetat (TRE) la factorii de transcriere protein-activatori - 1 (AP-1). Litiu sporeşte de asemenea expresia unei gene reporter pentru luciferazã iniţiatã în vitro de promotorul SV40 (Chen şi tot, 1998). Administrarea cronicã de litiu duce la creşterea activitãţii AP-1 in vivo şi in vitro. Aceste efecte asupra familiei de factori transcripționali AP-1 are capacitatea de a regla paternuri de expresie de genicã în circuite neuronale critice (Chen şi toate, 1998).

Multe gene sunt reglate de site-uri AP-1, printre care şi expresia genicã a tirozin hidroxilazei $(\mathrm{TH})$, controlatã de un promotor cu site-uri de legare AP-1, fiind bine caracterizatã implicarea AP-1 în reglarea expresiei TH în neuroni. Litiu, ĩn concentrații semnificative din punct de vedere terapeutic, creşte nivelul de TH la suprafaţa creierului de şobolan şi de asemenea în țesutul nervos uman (Chen et all, 1998).

Declanşarea transcrierii unor gene timpurii, inclusiv din familiile fos şi jun, este un rãspuns celular caracteristic la un mare numãr de stimuli celulari externi ca de exemplu hormoni, factorii de creştere, şi neurotransmițãtori. Declanşarea transcrierii este urmatã de traducerea citoplasmicã a Fos, Jun, şi a altor proteine, care se localizeazã în nucleu şi formeazã o varietate de complexe proteice. AP1 este o colecţie de complecşi de homo- şi heterodimeri ale produşilor familiilor de factori Fos şi Jun. Aceşti complecşi se leagã de un site ADN comun al elementului de rãspuns 12-O-tetradecanoilforbol 13-acetat (TRE) în domeniul de reglare al genei şi activezã transcrierea.

Genele reglate prin AP1 în CNS includ gene pentru diverse neuropeptide, neurotrofine, receptori, factori de transcriere, enzime implicate în sinteza de neurotransmițãtori, şi proteine care se angajeazã alãturi de elemente citoskeletale. Rezultatul final al aceastei cascade moleculare este schimbarea transcrierii genelor țintã selectate prin existenţa site-urilor specifice de legare la ADN, ĩn regiunile lor reglatorii, a acestor factori (Ikonomov şi Manji, 1999).

S-a demonstrat cã litiu are capacitatea de a mãri expresia unor proteine endogene a cãror gene sunt reglate prin AP-1. Litiu reglezã expresia genicã (cel puțin parțial) pe calea factorilor de transcriere AP-1. Prin efectele sale asupra familiei de factori transcipționali AP-1, determinã schimbãri strategice în expresia unor gene în circuite neuronale critice, efecte care în final stau la baza eficacitãții sale în tratamentul unei tulburãri neuropsihiatrice atât de complexe cum este maniaco-depresia. 
Mai multe studii au arãtat cã tratament cu litiu exercitã efecte complexe timpspecifice, pe nivelele bazale şi stimulate ale ARNm c-fos şi proteinele Fos. Aceste efecte ale litiului asupra familiei proteinelor Fos implicã protein kinaza $\mathrm{C}(\mathrm{PKC})$ şi se acceptã cã PKC joacã un rol în medierea efectelor litiului pe AP-1. Numeroase date au aratat cã proteina mitogen-activatã (MAP) joacã un rol cheie în reglarea AP-1. MAP kinazele transmit semnalele extracelulare la nucleu, unde se induce transcrierea genelor specifice prin sinteza, fosforilarea, şi activarea factorilor de transcriere. Trei cãi distincte de semnalizare au fost identificate în celulele de mamifer, care duc la activarea MAP kinazelor - kinazele ERK, kinazele c-Jun NH2-terminale (JNK), şi p38.

Membrii subgrupului JNK de MAP kinaze sunt activaţi de stimuli diferiţi şi fosforileazã site-uri specifice ale domeniului transactivator amino-terminal al factorilor de transciere C-jun. Fosforilarea pe aceste site-uri stimuleazã abilitatea factorilor C-jun de a activa transcrierea genelor țintã specifice. Pe lângã C-jun, factorii JNK fosforileazã şi activeazã alți câțiva factori de transcriere (incluzând Elk-1, ATF-2 şi NFAT4), dintre care majoritatea pot contribui la activarea AP-1. Recent s-a demonstrat cã PKC joacã un rol important în reglarea factorilor JNK.

MAP kinazele sunt prezente din abundențã în creier şi joacã un rol major în diverse funcțiile ale sistemului nervos central, fie el ĩn dezvoltare sau matur. MAP kinazele sunt implicate în procesele mediatoare neurochimice asociate facilitãrii pe termen lung, potențãrii de termen lung, învãţare asociativã, condiţionare clasicã, memoria spaţialã de lungã-duratã şi are rol ĩn integrarea informației de la multiple nivele sinaptice.

Recent, s-a demonstarat cã MAP kinazele regleazã rãspunsurile la stimuli ambiantali şi stressorsi la rozãtoare şi cupleazã PKA şi PKC la fosforilarea proteinei de legare a elementului de rãspuns ciclic AMP în aria CA1 din hipocamp. Aceste studii recente sugereazã posibilitatea unui rol important al cascadelor MAP kinazice în reglarea expresiei genelor de termen lung în plasticitatea sinapticã. MAP kinazele regleazã de asemenea alte proteine membranare, citoskeletale şi citosolice şi sunt implicate în reglarea diverselor funcții celulare pe termen lung. MAP kinazele sunt activate fiziologic de factori de creştere, factori neurotrofici şi neurotransmiţãtori.

Litiu activeazã familia JNK a MAP kinazelor. De vreme ce JNK sunt cunoscuţi ca reglatori majori ai legãrii AP-1 de ADN, efectele litiului asupra legãrii AP-1 la ADN sunt intermediate parțial prin efectele lui pe JNK. Litiu activeazã factorii JNK în creierul de şobolan în timpul expunerii cronice in vivo şi pe culturile neuronale umane şi ţinând cont de rolurile cheie ale factorilor JNK în reglarea diverselor aspecte ale functiiiilor neuronale şi de bine-cunoscutul rol în reglarea expresiei genice, aceastã caracteristicã a ionilor de litiu joacã un rol important în efectele terapeutice pe termen lung ale litiului (Yuan Peixiong, 1999).

Litiul este de asemenea un inhibitor al glicogen sintetaz kinazei $3 \beta$ care fosforileazã c-Jun la trei situri distanțã de domeniul de legare la ADN în felul acesta reducând activitatea AP-1. Creşterea nivelului activitãții AP-1 de legare la ADN este de asemenea intermediatã prin inhibiția glicogen sintetaz kinazei $3 \beta$. 


\section{Proprietãți clinice ale litiului}

Introducerea sărurilor de litiu în tratamentul sindromului maniaco-depresiv a constituit un mare succes. Sărurile de litiu au fost utilizate în psihiatrie începând din 1949: la mijlocul anilor $60 \mathrm{~s}$-a extins utilizarea lor şi astăzi sunt folosite în întreaga lume. Sărurile de litiu au rol în special în tratamentul profilactic al bolilor afective recurente unde sunt capabile să reducă sau să înlăture schimbarea comportamentului ducând la îmbunătăţirea calităţii vieții multor pacienţi şi a familiilor lor şi salvând mulţi pacienţi predispuşi la sinucidere.

Deşi tratamentul cu săruri de litiu este specific psihiatriei, în ultima vreme, s-au extins cercetările privind utilizarea lor şi în alte domenii: oncologie, dermatologie, virologie, imunologie etc. Sărurile de litiul sunt din ce în ce mai folosite în domenii diferite de psihiatrie şi pentru boli care nu aparţin maladiilor afective. Dacă respectarea dozei terapeutice determină reacții benefice, depăşirea acesteia declanşează o serie de perturbări care duc până la moartea individului.

Terapia cu săruri de litiu reprezintă a treia etapa capitală în chimioterapia psihiatrică (după tratamentul cu neuroleptice şi antidepresive). Acţiunea sărurilor de litiu constă în sedarea stărilor de agitaţie în special a agitaţiilor maniacale şi prevenirea recidivelor din psihoza maniaco-depresivă.

Tulburarea bipolară este o afecțiune psihiatrică ce se caracterizează prin alteARNrea unor episoade depresive cu episoade maniacale, care pot fi asociate cu manifestări psihotice de tipul halucinațiilor. Episoadele maniacale se caracterizează prin stări de euforie sau irascibilitate, tulburări cognitive şi tulburări psihomotorii. Debutul episoadelor maniacale poate fi acut sau subacut. Episoadele depresive pot fi prezente sau absente, în funcție de acest aspect diferențiindu-se trei tipuri de afecțiuni bipolare:

$>\quad$ Tulburare bipolară I (episoade maniacale şi/sau episoade depresive);

$>\quad$ Tulburare bipolară II (episoade hipomaniacale şi episoade depresive severe);

$>$ Ciclotimia (episoade hipomaniacale şi episoade depresive uşoare).

Studiile pe gemeni monozigoți şi prevalența mare la copiii provenind din familii cu istoric maniaco-depresiv dovedesc existența unei predispoziții genetice pentru tulburările bipolare. Boala poate apărea la orice vârstă, fiind mai frecventă la femei.

Stările de manie alternează ciclic cu cele depresive, boala tinzând să se agraveze în timp în lipsa unui tratament adcvat. Litiul este principalul medicament folosit în tratarea tulburărilor bipolare, înainte de descoperirea acestuia pronosticul bolii fiind foarte nefavorabil. Pacienții netratați prezintă un risc crescut de suicid. Tratamentul cu litiu este unul de lungă durată, doza terapeutică fiind de 90-1800 mg carbonat de litiu pe zi. Litiul se administrează sub formă de carbonat de litiu, care este considerat stabilizator al dispoziției. Carbonatul de litiu este folosit ca tratament cu o eficiență mai mică şi în tulburările unipolare caracterizate de depresii majore. 
Doza terapeutică şi cea toxică a litiului au valori foarte apropiate, aceasta reprezentând problema majoră în administrarea sărurilor de litiu sub formă de medicament antipsihotic.

Detaliile privind mecanismul molecular şi regiunea țintă ce justifică acțiunea de stabilizare a psihozei maniaco-depresive de către sărurile de litiu nu sunt pe deplin elucidate. S-a sugerat totuşi că sistemele generatoare de mesageri secundari care implică adenilat ciclaza şi fosfoinozitolii sunt potenţiale situsuri țintă (Jakobsen et all, 1998).

In sângele uman, ionii de litiu pot interfera cu aproape orice proces care implică ioni de sodiu, potasiu, calciu, magneziu, calmodulină, diferiți mesageri secundari, hormoni şi mulţi din neurotransmiţătorii cunoscuţi (Klemfuss et all, 1991).

Acțiunea terapeutică a sărurilor de litiu în bolile bipolare pare a fi rezultatul unui cumul de evenimente care modifică activitatea neuronală la nivele multiple. Trei mecanisme care interacționează par a fi mai afectate:

1) modularea neurotransmițătorilor de către ionii de litiu pare a modifica raportul dintre activităţile lor excitatorii şi inhibitorii iar descreşterea activităţii glutamatergice poate contribui la efectul litiului de neuroprotecție;

2) ionii de litiu modulează semnalele cu impact asupra citoscheletului, un sistem dinamic care contribuie la plasticitatea neuronală la nivele multiple, inclusiv glicogen sintaza kinaza-3 $\beta$, protein kinază cAMP dependentă şi protein kinaza C;

3) ionii de litiu modifică activităţile de semnalizare care implică mesagerii secundari, factorii de transcripție şi deci expresia genelor (Jope, 1999).

In ultimii ani, o noua etapã de interes asupra litiului a început prin descoperirea efectelor care nu au nici o legaturã cu utilizãrile sale psihiatrice. Multe din aceste efecte sunt determinate de modificãrile pe care litiul le induce asupra proceselor hematopoietice, în principal stimularea de cãtre litiu a leukocitozei care se produce datoritã creşterii mielopoiezei şi schimbãrilor la nivelul leucocitelor polimorfonucleare periferice. Factorii de stimulare ai coloniilor din mãduva osoasã înregistreazã nivele crescute în prezența litiului. Iniţial, acest efect a fost exploatat pentru tratamentul supresiei hematopoietice indusã de medicamente, de exemplu în chimioterapia cancerelor; dupã transplantul de mãduvã osoasã, sau dupã disfuncțiile induse de iradiere.

Metalul poate avea de asemenea efecte asupra rãspunsurilor imune la un numãr de provocãri antigenice ale organismului. S-a arãtat de altfel cã litiul poate influen'a o serie de citokine care regleazã diferențierea celularã, nu numai în cazul celulelor formatoare din sânge, dar şi în cazul multor altor tipuri de celule.

A. DERMATOLOGIE

Litiul este utilizat în aplicații externe în tratamentul unor afecțiuni dermatologice. Alifii ce conţin succinat de litiu s-au dovedit a fi eficiente şi sunt acum aprobate pentru utilizarea în tratamentul dermatitei seboreice, având atât un efect asupra metabolismului lipidic al fungilor Pityrosporul ovale, excesiv proliferaţi în acest caz, dar şi un efect asupra procesului inflamator declanşat de atacul acestor fungi. 


\section{B. VIROLOGIE}

La concentrații mari de litiu, în jur de $40 \mathrm{mM} / \mathrm{L}$, apare inhibiția replicãrii herpes, pox şi adenovirusurilor dar nu şi inhibiţia virusurilor $A R N$, cum ar fi influenza encephalomyocarditis. Un studiu ce a inclus şi cazul placebo, vizând o alifie conţinând $8 \%$ succinat de litiu a arãtat cã se face o vindecare mult mai rapidã a ulcerelor herpetice, excreția viralã fiind redusã. A existat de asemenea o descreștere a duratei durerii pacienților cu infecții genitale recurente cu herpes simplex.

\section{IMUNOLOGIE}

Mai multe procese ale rãspunsului imun sunt afectate de litiu in vivo şi in vitro, existând premise pentru utilizarea litiului în tratamentul unei boli autoimune - Lupusul eritematos sistemic (LES). Litiul creşte supraviețuirea şoarecilor NZB/W (un model pentru lupusul eritematos sistemic), iar renunțarea la tratament duce la reactivarea bolii şi moartea ulterioarã a animalului. Hormonul de stimulare al $\alpha$ Melanocitelor ( $\alpha \mathrm{MSH})$ singur nu poate creşte supravieţuirea şoarecilor, în schimb $\alpha \mathrm{MSH}$ în combinaţie cu litiu duce la prelungirea supraviețuirii.

\section{BOLI HEMATOPOIETICE SI IMUNOLOGICE SI AIDS}

Litiul influențeazã multe aspecte ale producției celulelor sângelui, în particular, formarea granulocitelor. Litiul este efectiv de fiecare datã când producția granulocitelor este defectã sau inadecvatã. Medicamentul antiviral zidovudine (AZT) a fost utilizat extensiv ca tratament al sindromului imunodeficien'ei dobândite (AIDS), deşi efectivitatea sa este limitatã de mielosupresie şi toxicitatea la nivelul mãduvei osoase pe care le induce.

Deşi AZT s-a arãtat cã este un agent efectiv care prelungește viața pacienților cu HIV, nu este lipsit de douã efecte nedorite: dezvoltarea rezistenței virale şi supresia mãduvei osoase. Nivelul toxicitãţii asupra mãduvei osoase este întotdeauna un factor de limitare a dozei în terapia viitoare, determinãnân fie reducerea acesteia, fie discontinuarea tratamentului cu acest medicament.

Datoritã capacitãţilor cationilor monovalenți de litiu de a modula mai multe aspecte ale hematopoiezei, cum ar fi inducerea neutrofiliei şi trombocitopoiezei, s-a postulat cã utilizarea litiului ar fi beneficã pentru pacienții cu imunodeficiențã trataţi cu AZT în cadrul terapiei antivirale.

Un model pentru AIDS este considerat şoarecele infectat cu LBM5LuMV, un virus complex ce determinã sindromul imunodeficienței murine (SIDAM).

Litiul, în combinație cu AZT, administrat în culturã celulelor normale de mãduvã osoasã sau in vivo, şoarecilor ce primesc o dozã crescãtoare de AZT, reduce semnificativ mielosupresia şi toxicitatea AZT asupra mãduvei osoase. Influențarea producției celulelor sangvine atunci când este administrat la şoareci normali urmând unei expuneri iniţiale la AZT au prezentat anemie, trombocitopenie şi neutropenie corelate cu doza şi care au putut fi provenite prin tratamentul combinat litiu-AZT. 
Acest efect a fost mult mai dramatic asupra neutrofilelor, eozinofilelor şi plachetelor circulante. Efectul asupra eozinofilelor cel mai interesant, deşi a primit pânã acum puținã atenție. $\mathrm{Cu}$ toate acestea, acest context poate avea implicații importante.

Indivizii imunocompromişi, cum sunt cei cu infecție HIV, devin în mod caracteristic susceptibili la infecții parazitare care creeazã de fiecare datã dificultãţi. Unul dintre mecanismele naturale de apãrare ale organismului împotriva invaziei parazitare este mediatã via eozinofile şi în urma AZT, aceastã categorie de celule se reduce semnificativ. Capacitatea defensivã a gazdei împotriva acestor organisme parazitare poate fi semnificativ redusã de utilizarea antiviralelor din grupa AZT. Tratamentul cu litiu previne aceastã reducere a eozinofilelor, observatã în cazul utilizãrii AZT. Studiile sugereazã cã administrarea litiului la pacienții AIDS ce primesc sau nu medicamente antivirale, pot beneficia de abilitãţile litiului de a stimula producția eozinofilelor şi este posibil sã se înregistreze o întârziere a apariției infecțiilor oportuniste asociate AIDS.

Cum influențeazã litiul producția eozinofilelor şi prin ce mecanisme specifice intervine în aceste procese rãmâne sã se descifreze prin experimente viitoare. Aceste studii susțin punbctul de vedere cã litiul poate juca un rol în tratamentul pacienților infectați HIV ce primesc terapie antiviralã. Litiul poate de asemenea sã reverseze limfomul asociat cu infecția MAIDS, care se asociazã cu cea din cazuistica umanã.

\section{E. ONCOLOGIE}

Litiul stimuleazã direct expresia genicã prin calea factorului transcripțional AP-1 şi este posibil ca aceasta sã explice diversitatea efectelor sale asupra diferitelor sisteme. Litiul singur apare a avea efecte antitumorale stimulând eliberarea factorului de necrozã tumoralã (TNF) prin stimularea macrofagelor. Potențialul litiului de a modifica activarea sau deactivarea unor citokine cu rol asupra celulelor tumorale a primit de asemenea o atenție deosebitã.

Litiul este de asemenea capabil sã ținteascã monocitele umane, determinându-le sã elibereze TNF- $\alpha$. Monocitele de la pacienții cu cancer de sân tratate cu LiCl elibereazã cantitãţi mai mici de TNF- $\alpha$. Decât cele de la pacienţii sãnãtoşi. Producția de IL6 la monocitele tratate a fost, in tot cazul, neschimbatã, şi se sugereazã cã este un factor care poate modera efectele litiului.

Sãrurile de litiu ale acidului gamma linolenic (LiGLA) au fost promovate pentru efectele de reducere a progresiei unei varietãţi de cancere, urmatã de demonstrarea citotoxicitãţii acidului gamma-linolenic şi a sãrurilor sale, in vitro, fațã de o gamã largã de celule maligne. Existã evidențe cã LiGLA are un efect antitumoral substanțial în cazul unui spectru de cancere. Se poate ca citotoxicitatea sãrurilor de LiGLA sã fie o combinaţie a unor efecte separate şi individuale ale acizilor graşi esenţiali şi ale ionului de litiu. Teste clinice sunt în derulare asupra cancerului pancreatic, un caz particular de tumorã agresivã cu un timp relativ de supraviețuire scurt în circumstanțe naturale.

LiGLA este de asemenea citotoxic fațã de celulele infectate HIV, iar acest lucru poate avea o semnificație viitoare în tratamentul AIDS. 


\section{Efecte secundare adverse ale litiului}

Carbonatul de litiu este administrat sub formă de tablete, doza fiind ajustată în funcție de individ. Ajustarea este necesară, deoarece concentrația plasmatică terapeutică a litiului este apropiată de cea toxică (Timmer şi Sands, 1999).

Intoxicația cu litiu poate fi acută sau cronică. Simptomele principale ale intoxicației cu litiu se prezintă astfel:

Tabelul 1. Principalele simptome ale intoxicaței acute şi cronice cu litiu (Timmer şi Sands, 1999)

\begin{tabular}{|l|l|l|}
\hline \multicolumn{1}{|c|}{ Localizare } & \multicolumn{1}{c|}{$\begin{array}{c}\text { Simptomele intoxicației acute cu } \\
\text { litiu }\end{array}$} & \multicolumn{1}{|c|}{$\begin{array}{c}\text { Simptomele intoxicației cronice cu } \\
\text { litiu }\end{array}$} \\
\hline Endocrină & Nici unul & Hipotiroidism \\
\hline Gastrointestinală & Greată şi vomă & Minime \\
\hline Cardiovasculară & Modificări EKG & Miocardită \\
\hline Hematologică & Leukocitoză & Anemie aplastică \\
\hline Neurologică & $\begin{array}{l}\text { - Tremor, fotofobie, slăbiciune; } \\
\text { - Apatie, amețeală, accentuarea } \\
\text { reflexelor; } \\
\text { - Confuzie, crize, comă }\end{array}$ & $\begin{array}{l}\text { - Aceleaşi } \\
\text { - Aceleaşi } \\
\text { - Deficiențe de memorie, Parkinson }\end{array}$ \\
\hline Neuromusculară & Miopatie şi neuropatie periferică & Aceleaşi \\
\hline Renală & Probleme de concentrare a urinei & $\begin{array}{l}\text { Nefrită intestinală cronică, diabet } \\
\text { insipid nefrogenic, insuficiență renală }\end{array}$ \\
\hline \multicolumn{1}{|c|}{ Piele } & \multicolumn{1}{|c|}{ Nici unul } & Dermatită, edem localizat, ulcerații. \\
\hline
\end{tabular}

Intoxicația cronică poate fi clasificată în fucție de severitatea simptomelor în intoxicație uşoară, moderată şi gravă. Simptomele celor trei grade de intoxicație se prezintă astfel:

Tabelul 2. Simptomele celor trei stadii de intoxicație cronică cu litiu (după Timmer şi Sands, 1999).

\begin{tabular}{|c|c|c|}
\hline Intoxicație cronică uşoară & $\begin{array}{c}\text { Intoxicație cronică } \\
\text { moderată }\end{array}$ & Intoxicație cronică gravă \\
\hline 1. greață & 1. confuzie & crize \\
\hline 2. tremor & nistagmus & sincope \\
\hline 3. amețeli & ataxie & insuficiență renală \\
\hline 4. diaree & schimbări EKG & creșterea reflexelor \\
\hline 5. letargie & dizartrie & comă \\
\hline 6. oboseală musculară & mioclonie & moarte \\
\hline
\end{tabular}

Litiul se concentrează la nivelul tiroidei şi inhibă sinteza şi eliberarea hormonilor tiroidieni, determinând hipotiroidism şi hipotermie (Timmer şi Sands, 1999). Pacienții aflați în tratament cronic cu litiu prezintă riscuri crescute de a dezvolta tireotoxicoza şi hipertiroidism (Oakley et all, 2000).

De asemenea, tireotoxicoza este implicată în dezvoltarea intoxicaţiei cronice cu litiu. În hipertiroidism, tiroxina creşte activitatea de transport a schimbătorului de $\mathrm{Na} / \mathrm{H}$, crescând reabsorbția sodiului la nivel renal.

Activitatea crescută a schimbătorului de $\mathrm{Na} / \mathrm{H}$ din rinichiul pacienților cu hipertiroidism implică creşterea reabsorbției litiului la nivel renal şi scăderea excreției 
acestuia, conducând la concentrații mari de litiu în sânge. Această creştere de concentrație apare în pofida creşterii filtrării glomerulare, prezente la pacienții cu hipertirodism, şi care ar fi trebuit să conducă la eliminarea litiului din organism.

Litiul poate masca simptomele clinice ale hipertiroidismului şi tireotoxicozei prin scăderea răspunsului tisular la hormonii tiroidieni. Studiile au demonstrat că litiul afectează funcția tiroidiană şi la nou născuți ( Oakley et all, 2000).

Litiul poate determina hiperparatiroidism şi hipercalcemie prin creşterea nivelurilor serice ale parathormonului. Hipercalcemia este ireversibilă sau puțin reversibilă. Hipercalcemia induce diabetul insipid nefrogenic, putând exacerba diabetul insipid produs de litiu (Timmer şi Sands, 1999).

Nefrotoxicitatea litiului poate fi împărțită în funcție de timpul de administrare în: diabetul insipid nefrogen, intoxicație acută şi boli cronice renale.

Mecanismul de acțiune al litiului al nivelul rinichiului este caracterizat de competiţia cu magneziul. Litiul inhibă proteinele $\mathrm{G}$ dependente de magneziu şi, prin aceasta, şi adenilat ciclaza. Cea mai frecventă afecţiune renală la pacienții trataţi cu litiu este diabetul insipid nefrogen, care se caracterizează prin poliurie şi polidipsie, prin incapacitatea de concentrare a urinei. Această incapacitate este datorată intervenției litiului asupra canalelor apoase reglate de vasopresină, aflate în membrana apicală a celulelor din tubul colector (Timmer şi Sands, 1999; Markowitz et all, 2000).

Un alt rezultat al toxicității litiului este considerat sindromul „floppy baby”. Nou născuții diagnosticați cu acest sindrom sunt hipotonici, cianotici şi prezintă probleme de hrănire (Austin şi Mitchell, 1998; Schou, 1998).

În cazurile de spongioză cerebrală determinate de intoxicația acută cu litiu, s-a observat pierderea neuronilor Purkinje de la nivelul cerebelului.

Studiile pe animale de laborator au demonstrat că intoxicaţia acută cu litiu produsă de administrarea clorurii de litiu (250 mg/Kg-corp) la şobolan, provoacă degenerare spongiformă cerebelară.

Aceasta se manifestă prin modificări la nivelul substanței albe de tipul vacuolizării. Vacuolizare uşoară a fost observată şi la nivelul trunchiului cerebral.

În cazul intoxicaţiei cu clorură de litiu, vacuolele sunt localizate intramielinic şi nu intraaxonal, ca în cazul encefalopatiilor spongiforme corelate cu demența. $\mathrm{Nu}$ a fost observată pierderea neuronilor Purkinje în cerebelul de şobolan, spre deosebire de cazurile de spongioză determinate de intoxicația cu litiu, raportate la om. Intoxicația acută cu litiu este reversibilă la şobolani (Dethy :i colab., 1997).

Turn-overul dopaminei şi serotoninei şi eliberarea dopaminei nu sunt afectate de intoxicația acută cu litiu. Aceasta demonstrează că efectele toxice ale clorurii de litiu asupra cerebelului nu sunt determinate de modificări ale transmiterii neuronale la nivelul sinapselor dopaminergice şi serotoninergice. 


\section{Afecțiunea bipolarã}

Afecțiunea bipolara este o afecțiune psihiatricã severã, comuna, caracterizatã prin asocierea unor episoade depresive cu episoade recurente maniacale sau mixte. Simptome cognitive, comportamentale şi psihice apar ĩntotdeauna în timpul episoadelor afective, iar rata de suicid în afecțiunea bipolarã este printre cele mai ridicate dintre toate bolile psihiatrice ( Keck, 2003)

Psihoza maniaco-depresiva a reprezentat, alãturi de schizofrenie, unul din cei doi piloni ai nosografiei psihiatrice clasice. În zilele noastre, psihozele afective polarizeazã atenția clinicienilor, care manifestã un interes crescut pentru acest grup nosografic. Dar interesul psihiatrilor, ca şi al medicilor ĩn general, pentru bolile afective nu este determinat numai de succesele ĩnregistrate ĩn cunoaşterea lor clinicã, etiopatogenicã sau terapeuticã, ci şi de prevalenţa crescutã a acestor tulburãri, dintre care numai cele semnificative din punct de vedere clinic reprezinta mai mult de $15 \%$ din ansamblul populației. Tabloul clinic al tulburãrii afective, cauzat ĩn special de caracterul sau bipolar, a pus ĩntotdeauna problema unei ĩncadrari unitare. Acest fapt se remarcã urmãrind evoluția istoricã a nosologiei tulburãrilor afective.

Bolile afective, din cauza caracterului elocvent şi episodic al evoluţiei, ca şi a dramatismului suferinței, au fost identificate şi descrise ĩnaintea celorlalte afecțiuni psihice, fiind consemnate ĩnca din primele mențiuni istoriografice.

Depresia, ĩn forma ei clinicã majorã, psihoticã, alãturi de manie, s-a impus atenției ĩnca din antichitate, fiind probabil prima boalã psihicã recunoscutã şi descrisã. Astfel, Homer, Plutarh, Hipocrat şi Aretaeus au descris boala "la fel de viu şi elocvent ca orice observator modern, semnalând circumstanțele de apariție, corelarea simptomelor, regularitatea remisiunilor, deosebirea de schizofrenie şi tulburarile senile, precum şi mãsurile medicale psihologice şi de mediu care trebuie luate ĩn seamã ĩn vederea tratamentului“" (Cohen, 1967).

Hipocrat, ĩn secolul al IV-lea ĩ.e.n., a folosit conceptul de "melancolie" ĩn altã ordine semanticã, desemnând prin aceasta "atra bila" (bila neagrã), ce ar conferi, ĩn concepția lui, prin predominanța acestui tip de bilã, anumite trãsãturi temperamentale. Deci, ĩn accepțiunea hipocraticã, melancolia nu exprima diagnosticul unei psihoze şi nici un semn de suferințã psihica, ci mai degraba o stare fiziopatologicã.

La rândul sãu, termenul de "manie" avea o accepțiune deosebit de largã, acoperind un vast sector nosografic, fiind sinonim cu nebunia (May et all, 2002).

În ceea ce priveşte relaţia dintre manie şi melancolie, ea a fost sesizatã ĩnca din secolul al II-lea de Aretaeus din Capadocia, aproximativ ĩn anul 150 e.n., ce realizeaza o descriere a psihozei maniaco-depresive (Adams, 1856).

În legaturã cu istoria bolilor afective, trebuie menţionat şi un fapt terapeutic referitor la sãrurile de litiu, folosite şi astãzi ĩn terapie. Astfel, se consemneazã cã, ĩn urmã cu 1500 de ani, ĩn secolul al V-lea, Aurelianus prescria pentru "nebunia maniacalã", melancolie şi alte boli fizice şi mintale "apa alcalinã din anumite izvoare minerale, ce au ĩn compoziția lor mari cantitãți de litiu” (May et all, 2002). 
Deşi antichitatea a recunoscut opoziţia termenilor manie - melancolie, ca şi alternanța, în timp, a acestor episoade, abia ĩn anul 1675 medicul englez Th. Willis a fost cel care a descris ştiințific unitatea lor, sugerând astfel existența unei singure afecțiuni, sub forma bimodalitãţii tabloului ei clinic (Marenos et all, 2000).

Ulterior, Ph. Pinel, ĩn prima jumãtate a secolului al XIX-lea, scrie un tratat despre manie, intitulat "Tratatul medico-filozofic al maniei", ĩn care descrie mania şi melancolia printre cele patru categorii de "alienație mintalã" cunoscute la vremea aceea, alaturi de demențã şi idioțenie, şi face, de asemenea, observaţii asupra trecerilor dintr-o stare afectivã ĩn alta (May et all, 2002).

La rândul sau, E. Esquirol, bazat pe caracterul circumscris, sectorial, al tulburãrilor psihice, descrie "mono-maniile", pe care le clasificã ĩn formele "intelectualã, instinctivã, afectivã, tristã", sinonime cu termenul de melancolie. Întrucat termenul de melancolie era folosit şi ĩn literatura vremii, cât şi de publicul larg, diluându-i-se astfel conţinutul psihopatologic, Esquirol îl ĩnlocuieşte cu acela de lipemanie. În plus, el considera cã termenul de melancolie exprimã tristețea comunã, ce nu are de-a face cu clinica psihiatricã. Prin aceasta, impune o distincție necesarã şi pe deplin actualã ĩntre "depresia clinicã" şi "depresia psihologica“, denumita şi "normala“"(Esquirol, 1838).

Ulterior, termenii de manie şi melancolie ĩşi restrâng treptat sfera de ĩnțelegere, iar accepțiunea lor actualã este acceptatã abia ĩn secolul al XIX-lea, când W. Griessinger (1845) descrie psihoza caracterizatã prin alternanţa unor accese maniacale şi melancolice, numitã "ciclotimicã” sau “ periodicã"(May şi col., 2002).

În 1853, J.P. Falret, dupa un studiu de peste 30 de ani, identificã o boala, pe care o denumeşte "la folie circulaire" şi care are o evoluție ciclicã. Episoadele se deruleaza cu o frecvențã crescutã, ĩntre ele existã perioade de normalitate, iar posibilitatea de recuperare a pacienților este mult mai redusa la cei cu perioade libere interepisodice de duratã scurta. Aceastã idee corespunde concepției moderne de ciclicitate rapidã a tulburãrii afective (Falret, 1854). În aceeaşi perioadã, Ballarger foloseşte termenul "la folie a double forme", subliniind evoluţia "succesivã şi regulatã" a stãrilor maniacale şi melancolice, urmate de un interval liber, menţionând, totodata, posibilitatea trecerii unei forme in alta (Baillarger, 1854).

În 1882, K. Kahlbaum evidenţiazã faptul cã mania şi melancolia nu sunt douã boli distincte, ci doar douã forme ale aceleiaşi entitãți şi descrie o boalã cu simptomatologie de intensitate redusã din punct de vedere clinic, pe care o denumeste "ciclotimie" (Kaplan, 1996).

Opiniile asupra tulburãrilor afective au fost destul de disparate pânã când diversele manifestãri şi forme clinice au fost reunite sub acelaşi generic de E. Kraepelin, fondatorul nosografiei psihiatrice, ce a creat conceptul de "psihozã maniaco-depresiva" (Kraepelin, 1899). Autorul ĩmparte "psihozele funcționale" in "demenția praecox" şi "boala maniacodepresivã ă. De asemenea, bazându-se pe criterii clinice, el reuneşte sub acest concept nosografic mania şi melancolia, deoarece se succed una dupa alta şi au un prognostic 
favorabil, constituind "o manifestare diferita a aceleiaşi entitãţi clinice subiacente". Criteriile nosografice kraepeliniene sunt urmatoarele:

- tabloul clinic este dominat de nucleul tulburãrilor afective, accesele de manie şi depresie constituind doi poli ĩntre care se produc aceste manifestãri;

- ĩn favoarea unitãţii acestor faze pledeazã evoluţia, observatã la acelaşi bolnav, de la o stare la alta;

- ĩn antecedentele eredo-colaterale ale bolnavului exista manii şi melancolii, ca expresie a nucleului endogen-ereditar al bolii.

În 1913, pentru prima oara ĩn spaţiul german, a fost desemnatã de Kraepelin noțiunea de „stare de nebunie maniaco-depresiva". În acelaşi timp, apar prin Jaspers $(1913,1959)$ mai multe ĩncercãri de definiţie a tulburãrilor afective şi se impune tot mai mult noțiunea de „psihozã maniaco-depresivã”. În 1916, Bleuler defineşte noțiunea de „triadã depresivã”, ințtelegând prin aceasta dispoziție depresivã, inhibiţia gândirii şi inhibiţia funcției centrifuge de a hotarâ şi de a acționa.

Spre deosebire de Kraepelin şi Bleuler, K. Leonhard şi psihiatria scandinavã, mai tarziu şi studiile fãcute de Angst şi Peris (1966) diferențiazã noțiunile de "psihoze monounipolare şi bipolare". Sub denumirea de psihozã maniaco-depresivã, autorul include şi situațiile ĩn care pacientul prezintã ĩn evoluție doar episoade depresive, fãrã episoade maniacale evidente. De asemenea, el considera cã aşa cum ĩn evoluția bolii pot exista episoade maniacale, urmate, uneori, de episoade depresive minore, fãrã semnificație clinicã deosebitã, aceeaşi posibilitate evolutiva existã şi ĩn cazul episoadelor depresive.

În 1921 si 1959, Kleist va ataca nosografia kraepeliniana, afirmând cã mania şi melancolia nu sunt manifestãri ale unei psihoze unitare. El se bazeazã pe faptul cã aceleaşi cauze determinã complexe simptomatice diferite şi şterge, astfel, diferenţa dintre noțiunile de maladie şi sindrom, minimalizând importanţa etiologiei şi acordând atenţie doar patogeniei. Astfel, el separã o grupã de "fazofrenii", ĩn care include, alãturi de psihoza maniaco-depresivã, pe care o denumeşte "fazofrenie bipolara", si schizofrenia (Leonhard, 1979).

În 1957, K. Leonhard, continuând teoriile lui Kleist, considera cã, exceptând psihoza maniaco-depresiva, mai exista şi alte psihoze afective endogene. El afirma cã nu toate maniile şi depresiile trebuie incluse ĩn sfera psihozei maniaco-depresive, care este doar un subtip al psihozelor afective endogene. Astfel, autorul va separa trei forme de psihoze bipolare atipice, denumite "psihoze cicloide", care se deosebesc ĩntre ele doar prin raportul dintre simptome. Pe de altã parte, el preconizeazã diferențierea formelor unipolare ale tulburãrilor afective, idee ce va fi ulterior susţinutã şi de trei studii independente realizate ĩn Suedia (C. Perris, 1966), Elveția (J. Angst, 1966) şi SUA (G. Winokur, P.J. Clayton, 1967).

În pofida acestor opinii divergente, care au fragmentat nosografia kraepeliniana şi conceptul unitar de psihozã maniaco-depresivã, acesta şi-a menţinut valabilitatea. Totuşi, nici acest concept nu respectã periodicitatea şi, mai ales, alternanţa episoadelor afective, asa cum autorul a ĩncercat sã i-o confere acestei boli, ĩn efortul de edificare nosografica. 
Aceasta se datoreazã faptului cã, ĩn unele cazuri, boala implicã numai episoade depresive sau numai episoade maniacale şi doar uneori se ĩntalnesc, la acelaşi bolnav, episoade maniacale alternând cu episoade depresive.

Reorientãrile din domeniul nosografiei bolilor afective au creat mari dificultãți ĩn privința definirii psihozei maniaco-depresive. În plus, accepțiunile diferite in care se foloseşte noțiunea de depresie, ca şi readucerea ĩn nosografie a termenului de melancolie, la care se renunțase ĩn ultimele decenii, impun anumite clarificãri semantice ale acestor noțiuni polisemice (Chiriţã, 2002).

În acest proces de reconsiderare nosografica şi de clarificare semanticã, a fost abordat şi termenul de tulburare afectivã şi, respectiv, de afectivitate. Astfel, se considerã cã nu afectivitatea, care semnificã tonalitatea emoţionalã individualã şi pasagerã, ci dispoziţia constituie expresia emoționalã bazalã şi constantã, care "coloreazã comportamentul" şi "ĩntreaga viaţã psihica". Din aceste considerente, termenul de tulburare a dispoziției (mood disorder) este mai adecvat pentru a ilustra manifestãrile clinice (Akiskal şi Mallya, 1987).

Noțiunea de psihozã maniaco-depresivã a fost rapid adoptatã şi utilizatã pentru expresia ei sinteticã şi nevoia de unitate nosografica. Cu toate acestea, termenul a devenit ambiguu, unii clinicieni folosindu-l ĩn sens kraepelinian, originar, iar alții ca sinonim pentru boala bipolara. În accepțiunea lui Kraepelin, "psihoza maniaco-depresiva“ este o afecțiune caracterizatã clinic prin episoade maniacale şi depresive, care survin la acelaşi bolnav ĩn cursul existenţei sale. În plus, episoadele de polaritate clinicã diferitã erau prezentate ca evoluând cuplat, fapt care a constituit criteriul esenţial al unitãţii bolii şi a impus denumirea ei.

Psihoza maniaco-depresivã a ramas modelul central al tulburãrilor afective. Fãrã a neglija concepția unitarã a lui Kraepelin, ĩn prezent, din punct de vedere nosografic, se fac referiri la douã categorii de tulburãri: tulburãri bipolare şi tulburãri unipolare.

Aceste douã categorii, la rândul lor, sunt structurate ĩn mai multe tipuri clinicoevolutive, ca de exemplu, bipolar I, II, III pentru tulburãrile bipolare, care au rãmas paradigma psihozei maniaco-depresive. Tulburãrile bipolare sunt caracterizate, ĩn mod esențial, prin unul sau mai multe episoade maniacale, ĩnsoțite de unul sau mai multe episoade depresive. Termenii de "unipolar" şi "bipolar" au fost introduşi ĩn literatura de specialitate de Karl Kleist, fiind ulterior preluaţi de discipolii sãi Neele şi Leonhard. Conceptul sau de "tulburare bipolarã“", spre deosebire de termenul de psihoza maniacodepresiva, includea trei forme de psihoze cicloide (atipice).

Distincția unipolar-bipolar lasã multe stãri afective ĩn afara acestor limite. Printre aceste situatii se afla şi cea a rudelor pacienţilor bipolari care dezvoltã relativ frecvent, ĩn proporție de $3-4 \%$ dintre cazuri, episoade depresive. Aceste persoane, fenotipic unipolare sunt genotipic bipolare, estimându-se cã $4-5 \%$ din populația generala aparține spectrului bipolar "de granițã", cu predominanța episoadelor depresive şi cu caracteristici bipolare "mute". 
H.S. Akiskal si Mallya propun conceptul de "soft bipolar spectrum", utilizând astfel un termen mai general pentru tulburarea bipolarã. Acest concept include, in afara clasicei manii, episoadele depresive ĩnsoțite de episoade hipomaniacale (bipolar II), ciclotimia, stãrile hipertimice, episoadele hipomaniacale apãrute ĩn timpul tratamentului chimioterapic, psihoterapic sau survenite la un pacient cu antecedente familiale de tulburare bipolara (bipolar III).

Spectrul bipolar, dupã H.S. Akiskal, cuprinde urmatoarele forme:

- tip I - manie spontanã;

- tip II - hipomanie spontanã;

- tip III - manie/hipomanie farmacologicã şi/sau istoric familial de BP (BP tip IV);

- tip V - ciclotimie;

- pseudounipolar - bipolaritate discretã sau soft bipolar stigma;

- temperament bipolar - ciclotimie, distimie, hipertimie, iritabilitate;

- stãri mixte - manie disforicã, stare depresivã mixtã.

$\mathrm{Cu}$ toate cã distincţia ĩntre boala afectivã unipolara şi bipolarã este deosebit de clarã, criteriile de includere ĩntr-o anumitã formã de polaritate nu se bucurã de unanimitate. În aceastã privințã intervine o nuanțare, ĩn sensul cã situaţia este mai simplã pentru formele bipolare, dificultãţi intervenind ĩn stabilirea formelor unipolare. În multe cazuri, episoadele depresive sunt subdiagnosticate, mai ales atunci când ele sunt de scurtã duratã şi includ o simptomatologie mai puțin specificã decât pierderea de energie, hipersomnia etc. De aceea, mania unipolara este recomandabil a fi consideratã ca o variantã clinicã a tulburãrilor bipolare, deşi studiile lui J. Angst au ĩncercat sã reabiliteze atât conceptul de manie unipolarã, cât şi de manie purã (Endicott, 1989; Klerman, 1981).

Diagnosticele actualmente ĩn vigoare, ce stau la baza principalelor sisteme de clasificare, se bazeazã pe elemente anamnestice si semiologice, adicã pe criterii clinice, ce erau valabile şi cu un secol in urma. Deşi operaționale clinic, aceste criterii diagnostice nu au caracter ştiințific, fiind supuse unor factori de entropie, care survin din multiple surse, ce aparțin psihiatrului, pacientului şi subiectivitãții procesului.

Interviurile standardizate şi semistandardizate limiteazã intr-o masurã variabilã influența entropicã a subiectivitãții simptomatologiei, fãrã a putea, ĩnsa, sã ofere procesului diagnostic o valoare ştiinţificã. De asemenea, diagnosticul oricarei condiţii clinice trebuie sã se bazeze pe criterii de includere şi de excludere specifice.

Aceste eforturi de conceptualizare a datelor clinice şi de diagnostic au drept scop crearea unor grupe nosografice omogene, de ĩnaltã validitate, susceptibile de a fi tratate mai eficient şi cu mai mare specificitate. Astfel, ĩmbunãtãţirea taxonomiei tulburarilor afective, pe baza unor pattern-uri simptomatice specifice, a unor informații genetice şi a unor markeri enzimatici şi biochimici, poate oferi indicaţii terapeutice eficiente şi sistematice. În DSM IV, mania, distimia şi ciclotimia sunt subsumate ĩn categoria "Mood Disorders" (tulburãri dipoziționale), pe cand ĩn ICD10, ele sunt numite tulburãri afective.

Dupa Dunner et al. (1976), tipizarea tulburãrilor bipolare se face ĩn: tulburarea bipolarã I - depresie majora + manie, şi tulburarea bipolara II - depresie majorã + 
hipomanie. În clasificarea internaţionalã modernã s-a renunțat la ipotezele etiopatogenice care stau la baza noțiunii de boalã. Rolul preponderent îl ocupã tipizarea, care se orienteazã pur descriptiv dupã dimensiunea simptomatologiei, durata şi gravitatea bolii. Astfel, noțiunea de distimie şi ciclotomie ocupa o ĩnsemnatate aparte.

Tabloul clinic se diferențiazã ĩn episodul depresiv, episodul maniacal şi episodul mixt (bipolar sau mixt maniaco-depresiv). Între episoade, pacienții pot fi asimptomatici; cu cât dureaza mai mult boala, cu atât ciclurile (durata de la ĩnceputul unui episod pânã la ĩnceputul episodului urmãtor) sunt mai scurte şi probabilitatea apariţiei simptomelor reziduale este mai mare.

În mod tipic, tulburãrile bipolare constau ĩn alternanța episoadelor maniacale şi a celor depresive, ĩntrerupte de perioade de normalitate. $O$ formã aparte este tulburarea bipolarã mixtã, ĩn care apar ĩn acelaşi timp simptome maniacale şi depresive sau cu schimbare rapidã - ĩn interval de o saptamana (in DSM IV), aproape zilnic.

În acest caz, apar zile, rar sãptãmâni, ĩn şir, urmãtoarele simptome:

- dispoziţie depresivã, ĩnsoțitã de hiperactivitate, logoree, delir de grandoare;

- dispoziție euforicã sau disforicã, cu stãri de agitație psihomotricã, ĩn acelaşi timp, inhibiție motricã;

- schimbare de dispoziţie rapidã ĩntre euforie şi depresie, cu labilitate şi incontinenţã afectivã, hiperexcitabilitate, tulburãri de comportament cu coloraturã demonstrativã;

- inhibiție motorie cu tablou substupuros, mutism amestecat cu stãri extatico-euforice;

- anxietate, tulburãri hipocondrice, mixate cu logoree;

- fugã de idei cu inhibiţie psihomotorie;

- simptome psihotice pasagere cu idei delirante, ocazional şi halucinații.

Alte forme speciale de tulburare afectivã bipolarã sunt:

- tulburarea bipolarã II, cu predominanța episoadelor hipomaniacale;

- „ciclarea rapidã”: schimb zilnic ĩntre episoadele depresive, cele maniace şi linişte simptomatologica, conform definiției, cel puțin patru episoade pe an. Apare la $5-15 \%$ dintre pacienţi $(70-80 \%$ sex feminin), de multe ori ĩn legaturã cu tulburari organice, ca de ex. hipotiroidism sau consum de droguri;

- tulburare afectivã recidivantã hipomaniacalã de scurtã duratã.

Din punct de vedere etiologic, se iau ĩn consideraţie modele neurobiologice şi genetice. Factorii psihosociali sunt consideraţi favorizanţi pentru declanşarea mai ales a episoadelor depresive, ĩnsa nu sunt determinanți. În special la tulburarea afectivã bipolarã un rol primordial îl joaca factorii genetici, rata de concordanțã la gemenii monozigoți fiind de $65 \%$, iar la cei bizigoți, de $20 \%$. Rata de morbiditate la rudele bolnavilor cu tulburare bipolarã este cuprinsã ĩntre $5 \%$ şi $25 \%$.

Neurobiologic, se vorbeşte despre o lipsã de echilibru ĩntre neurotransmițãtori (ĩn special creşterea concentrației aminelor ĩn spațiul sinaptic, niveluri scãzute de noradrenalinã şi serotoninã - ĩn cazul episoadelor depresive - şi accelerarea metabolismului catecolaminelor - ĩn cazul episoadelor maniacale); de asemenea, este invocatã modificarea densitãţii şi sensibilitãţii receptorilor. 


\section{Neurobiologia afecțiunii bipolare}

Teorii biologice timpurii privind pato-fiziologia maniaco-depresiei au avut în vedere diferiți neurotransmițãtori, în special aminele biogene.

Ĩn ultimul timp, evoluția înțelegerii noastre privind mecanismele celulare care stau la baza intercomunicãrii neuronale au direcționat cercetãrile cãtre situsurile post-receptor. Ĩntr-adevãr, revoluția medicinii moleculare a condus spre o mai bunã înțelegere a etiologiei şi pato-fiziologiei unei game largi de afecțiuni medicale.

$\mathrm{Cu}$ toate acestea, în contrast cu progresul fãcut în elucidarea etiologiei şi patofiziologiei atâtor condiţii patologice, nu s-a reuşit pânã acum identificarea şi explicarea convingãtoare a substratului genetic şi proteic al maniaco-depresiei.

Manifestãrile comportamentale şi fiziologice ale tulburãrilor bipolare sunt complexe şi trebuie privite nu numai din perspectiva schimbãrilor de dispoziţie ale pacienţilor, dar şi din prisma constelaţiei de simptome (manifestãri) neurovegetative şi psihomotorii. Pato-fiziologia este cu certitudine mediatã de o vastã rețea de interconexiuni ale circuitelor neuronale permise de neurotransmițãtori de la nivel limbic, striatal şi fronto-cortical, şi din acest punct de vedere, interacțiunea sistemelor de neurotransmiţãtori colinergici, catecolaminergici şi serotoninergici reprezintã un candiat sustenabil pentru investigații. De aceea nu este surprinzãtor cã studiile clinice din ultimii peste 40 de ani s-au centrat în mare parte, asupra conceptelor fundamentale cã semnalizarea monoaminergicã şi întreruperea axei hipotalamo-pituitar-adrenalã (HPA) sunt esențiale pentru înțelegerea şi explicarea patofiziologiei depresiei şi maniei (Manji et all, 2003).

O adevãratã înțelegere a tulburãrilor bipolare trebuie sã conceptualizeze neurobiologia acestora la diferite nivele fiziologice: molecular, celular, sistemic şi comportamental. Ideea cã afecțiunea bipolarã ar putea fi determinatã de o alterare a structurii creierului a apãrut în urma mai multor studii clinice care au prezentat observații cã anumite leziuni ale creierului, produse în urma unor tumori, a stroke-ului sau leziuni craniene au dus la comportamente asemãnãtoare celor din episodul maniacal.

Ĩn general, orice leziune a creierului este, mai degrabã, determinantã pentru inducerea unei depresii, dar leziuni care induc mania se produc frecvent în lobii temporal şi frontal, iar subcortical, la nivel talamic şi caudat. S-a sugerat de multe ori cã leziuni ale lobului frontal stâng determinã depresie, în vreme ce leziuni fronto-temporale în dreapta duc la manie. Pânã acum, aceste generalizãri s-au dovedit a fi destul de simpliste, fiind observate foarte multe excepții.

Mai mulți cercetãtori au sugerat cã pacienții cu tulburãri afective au ventriculi cerebrali mai mari decât în cazurile normale, un aspect mult mai evident la pacienții cu schizofrenie. Mãrirea ventricularã este o caracteristicã a pierderilor celulare, aşa cum ar fi neurodegenerarea observatã în cazul maladiei Alzheimer, sau alterãri ale circuitelor neuronale. Din pãcate, intervenția altor factori determinanți, precum alcoolul, consumul de droguri şi leziunile cerebrale nu dau ocazia unei interpretãri uşoare a acestor rezultate. 
Cunoscând aceste limitãri, studii volumetrice imagistice au dus la dezvãluiri interesante în cazul afecțiunii bipolare. Aşa cum recent a prezentat Strakovski et all., 2002, atât depresia bipolarã cât şi cea unipolarã sunt constant asociate cu volume mai mici ale lobilor prefrontali, în contrast cu o marime considerabilã a ganglionilor bazali şi a talamusului la pacienții maniaco-depresivi.

De mai multe ori, a fost raportatã o creştere a volumului hipocampusului şi al amigdalei în cazuri de psihozã maniaco-depresivã, dar din pãcate aceste raportãri nu sunt foarte consistente.

Schimbãri specifice de volum în diferite regiuni ale creierului pot fi determinate ca rãspuns la o varietate mare de factori şi nu au neapãrat un caracter permanent. Imagini de rezonanțã magneticã ale creierului obținute de la pacienții cu afecțiune bipolarã au relevat existența unui numãr neordonat de regiuni hipertensive. Aceste zone intense neidentificate (ZIN) sunt tipic asociate cu afecțiuni vasculare, inclusiv hipertensiune sistemicã, afecțiunea Binswanger şi ateroscleroza carotidicã. Studii ulterioare au arãtat ca aceste zone - ZIN tind sã se localizeze în structuri din substanța albã în adâncime. Procentul pacienților care prezintã astfel de zone este între 5 şi $50 \%$, în comparație cu lotul control, la care procentul este de numai $3 \%$.

Pacienții maniaco-depresivi în vârstã au un numãr mai mare de ZIN în substanța albã. Locația lor sugereazã un posibil rol în întreruperea comunicãrii între regiunile frontal-temporale, ceea ce poate reprezenta un suport pentru observaţiile anterioare cã leziunile în aceste regiuni au ca şi consecințã starea maniacalã.

Studii consecutive postmortem ale pacienților cu ZIN au demonstrat prezența unor modificãri histologice în aceste regiuni, inclusiv mici malformații vasculare, spații perivasculare dilatate, chişti cranieni, zone de infarct şi necrozã. Acestea sunt leziuni nespecifice surprinzãtoare în acest caz, dar care pot fi însã cauzate de multipli factori. De aceea, este posibil ca aceste leziuni sã reprezinte consecințe ale unui proces comorbid asociat afecțiunii bipolare.

Studii recente la copii şi adolescenți cu manie continuã însã sã prezinte o abundențã a acestor ZIN. Foarte recent, imagini de rezonanţã magneticã ale schimbãrilor apãrute în maniaco-depresie au relevat o similaritate apreciabilã cu imaginile obţinute în cazul unei afecțiuni denumitã: arteriopatie cerebralã autosomal dominantã cu infarcte subcorticale şi leucoencefalopatie (CADASIL - cerebral autosomal dominant artheriopathy with subcortical infarcts and leukoencephalopathy), existând dovezi pentru o mare incidențã a maniaco-depresiei la pacienții CADASIL (Berns and Nemeroff, 2003).

Studii de imagisticã structuralã au demonstrat o reducere a volumului substanței cenuşii ĩn arii orbitale şi mediale ale PFC (cortexul pre-frontal), striatumului ventral şi ale hipocampului şi o creştere a volumului ventricular la pacienţii cu tulburãri afective. Complementar, studii neuropatologice postmortem au arãtat reduceri anormale ĩn volumul cortical, a numãrului de celule gliale şi/sau ĩn marimea/densitatea neuronalã ĩn cortexul geniculat prefrontal, cortexul orbital şi cortexul prefrontal dorso-lateral la 
pacienții uni- şi bipolari. Cu toate acestea, deşi multe studii preliminare de acest gen sunt extrem de interesante, ele necesitã replicãri viitoare.

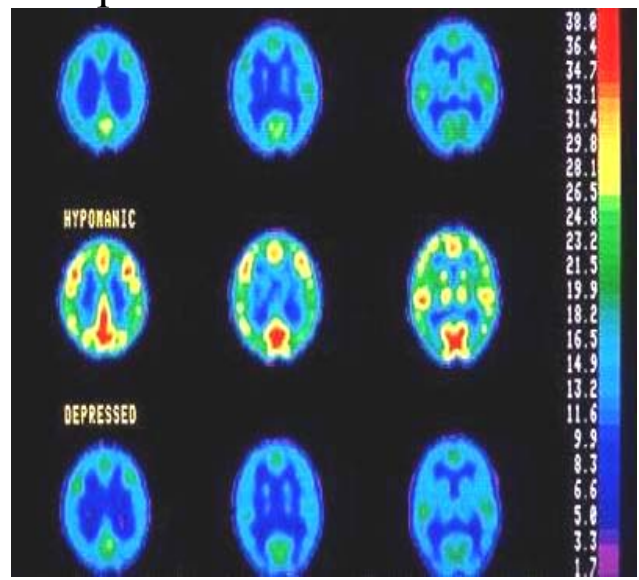

Figura 8. Aspecte de rezonanțã magneticã la maniaco-depresivi

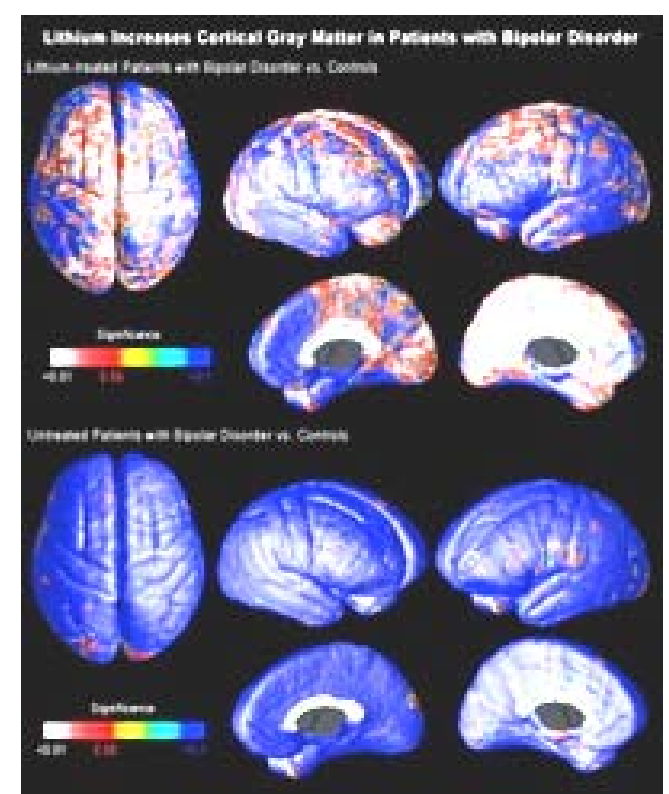

Figura 9 Studii imagistice la maniaco-depresivi
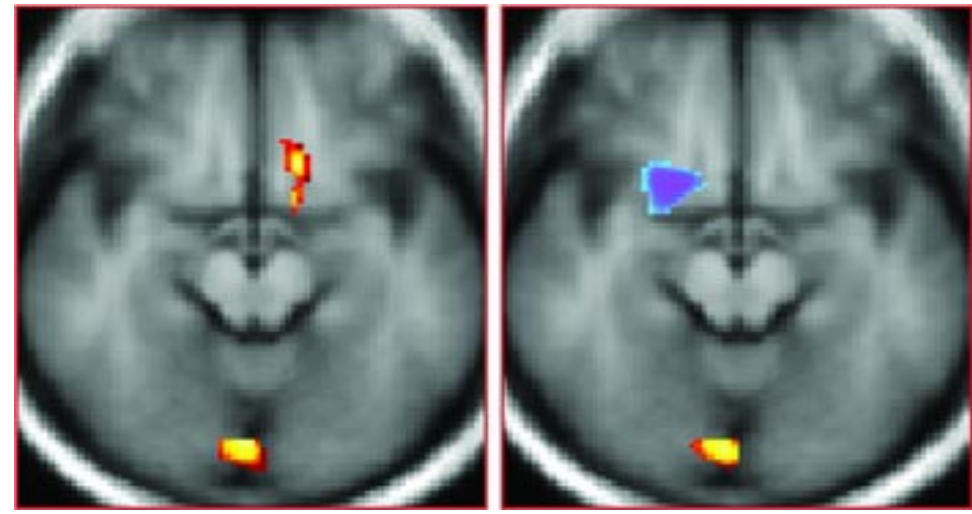

Figura 10. Aspecte tomografice la maniaco-depresivi 
Reducerea semnificativã a celulelor gliale ĩn aceste regiuni este ĩn mod particular interesantã sub aspectul rolurilor critice pe care celula glialã le are ĩn creşterea şi dezvoltarea neuronilor, ĩn reglarea concentraţiilor post-sinaptice ale glutamatului, ĩn homeostazia energeticã a sistemului nervos central, precum şi ĩn eliberarea factorilor trofici care participã la dezvoltarea şi menținerea rețelelor sinaptice formate de procesele neuronale şi gliale. Anomaliile funcționarii gliale se pot dovedi prin urmare determinante pentru condițiile patofiziologice şi de plasticitate structuralã ale tulburãrilor afective

Primele studii imagistice funcționale s-au axat asupra schimbãrilor majore atât de flux sanguin cât şi ale metabolismului. Aceste studii au arãtat cã pacienții bipolari depresivi - au un metabolism mult mai scãzut decât subiecții de control, sau cei cu depresie unipolarã. Mai departe, au fost conexate la starea dispoziționalã, observându-se dispariția acestor anormalitãţi dupã revenirea din starea de depresie. Aceste date nu au fost ĩncã suficient replicate. Unele studii au raportat un metabolism cortical normal, dar au fost depistate anormalitãti mult mai strict localizate, la nivelul unor regiuni precum cortexul prefrontal caudat sau geniculat.

Regiuni frontale, ĩ special cortexul prefrontal dorso-lateral, au fost identificate ca având un flux sanguin şi un metabolism scãzut pe timpul depresiei. Scãderile ĩn regiunea prefrontalã dorso-lateralã stângã au putut fi corelate cu severitatea depresiei, dar acest lucru se pare cã nu ar fi specific numai afecțiunii bipolare. Hipometabolismul frontal a fost ĩn mod repetat raportat ĩn cazurile de schizofrenie. Prezumtiv, orice alterare la nivelul acestor regiuni se asociazã cu efecte profunde asupra cogniţiei şi emotivitãţii. Se cunoaşte cã aceste regiuni ale creierului sunt integrative pentru multe funcții care suferã alterãri ĩn afecțiunile psihiatrice, cum ar fi atenția sau memoria de lucru.

Alte regiuni frontale, ĩn special acelea din straturile interne ale creierului sunt mai puțin ĩnțelese, dar par a fi implicate ĩn monitorizarea conflictului, evaluarea consecințelor şi inhibiția rãspunsului.

Imaginile neuro-funcționale din afecțiunile bipolare au corectat mitul precum cã organizarea creierului, ĩn mod particular procesele cognitive, pot fi localizate la nivelul unor regiuni izolate ale creierului. Virtual, fiecare imagine studiatã a reliefat rețele de activitate. În acest context, a devenit clar cã anormalitãțile nu pot fi catalogate drept regionale. De vreme ce procesele cognitive necesitã funcții coordonative ale mai multor regiuni ale creierului, atunci o micã alterare ĩn una dintre regiuni poate cauza efecte dramatice ĩn ĩntregul circuit neuronal.

Atât mania cât şi depresia se caracterizeazã prin schimbãri globale profunde ĩn funcționarea creierului. Aceste schimbãri de stare se manifestã la nivele multiple ale sistemului nervos. Existã aspecte ale funcțiilor neuronale care sã ĩi facã pe pacienții maniaco-depresivi mai ĩnclinaţi la aceste schimbãri? Noua teorie a haosului caracterizeazã aceste stãri ca atractori. Considerând cazul simplist al existenței doar a 3 stãri: eutimia (dispoziţia normalã), depresia şi mania - pentru cei mai mulţi indivizi eutimia reprezentând starea obişnuitã. Evenimentele neplãcute cauzeazã distimii 
tranziente, dar cei mai mulţi indivizi revin rapid la starea lor de dispoziţie obişnuitã. În mod similar, câş̧igul la loterie ĩi face pe cei mai mulți oameni foarte fericiţi, dar asta nu le induce apoi o stare permanentã de bucurie. Eutimia este aşadar o stare stabilã pentru cei mai mulți indivizi - perturbãrile sunt mici, iar revenirea la eutimie este o invariantã. Prin contrast, la pacienții cu afecțiune bipolarã, shift-ul spre manie sau depresie fãrã ĩntoarcere la dispoziția eutimicã este setat pentru o considerabil mai lungã perioadã de timp.

Spectroscopia de rezonanțã magneticã (MRS) a fost utilizatã extensiv pentru a mãsura schimbãrile relative de concentrație a mai multor neuroreglatori importanţi din creier la pacienții bipolari. Cea mai obişnuitã metodã, proton - MRS, este utilizatã atât ĩn investigații de rutinã cât şi ĩn studii clinice. Proton - MRS mãsoarã concentraţia relativã de N - acetil aspartat (NAA), creatinã (Cr), fosfocreatinã (PCr), şi diferiți compuşi cu colinã (Cho). Deoarece litiul crește concentrația colinei ĩn hematii este rezonabil sã privim spre efecte similare şi ĩn creier. Datele de MRS asupra colinei nu sunt pe deplin concludente, dar existã totuşi un consens cã apare cel puțin o creştere a raportului $\mathrm{Cho} / \mathrm{Cr}$ ĩn ganglionii bazali la maniaco-depresivi. Este posibil ca aceste rezultate sã fie dependente de dispoziție deoarece creşteri similare au fost observate ĩn depresie.

Deoarece peak-ul de colinã ĩn proton - MRS este reprezentat de mai multe componente, fosfor - MRS a putut sã deceleze, ulterior, natura acestor alterãri. Fosfor MRS poate distinge ĩntre ATP, P-Cr şi fosfo-monoesteri (PME) precum fosfo-colina, fosfo-inositol şi fosfoetanolamina. De asemenea, poate mãsura indirect $\mathrm{pH}$-ul intracelular şi magneziul liber.

$\mathrm{Cu}$ toate acestea, datoritã concentraţiei relativ mici a acestor compuşi, P-MRS este limitatã tehnic şi prezintã o senzitivitate modestã. Multe studii au gãsit schimbãri cantitative de fosfomonoesteri ĩn lobii frontali ai pacienților simptomatici, dar nu existã consens ĩn privinţa creşterii sau descreşterii, sau ĩn privința asimetriei stânga/dreapta. Minimal, aceste studii sugereazã alterãri ĩn metabolismul fosfolipidic la pacienții maniaco-depresivi.

Schimbãrile sunt evidente virtual la toate nivelele sistemului nervos central al pacienților bipolari. Astfel, dacã afecțiunea se manifestã prin schimbãri ale atractorilor dispoziţionali din creier, ĩn opoziție cu leziuni ale unei regiuni specifice la nivelul sãu, atunci cercetãrile trebuie sã cuprindã cauze de un nivel mult mai fundamental. Numeroase anormalitãți biochimice au putut fi detectate prin mãsurarea unuia sau altuia din metaboliții neurotransmițãtorilor sau hormonilor din plasmã, lichid cerebrospinal sau studii tisulare post-mortem. Deşi depresia a fost mai totdeauna conceptualizatã ca fiind cauzatã de o deficiențã funcționalã a activitãții unui anumit sistem de transmitere monoaminergic (serotoninã, dopaminã sau norepinefrinã), acestea nu au putut fi ĩncã ĩn mod clar implicate ĩn patofiziologia tulburãrii bipolare. Multe antidepresive care cresc activitatea unuia sau mai multor astfel de circuite de neurotransmitere pot sã precipite apariţia episodului maniacal (Berns and Nemeroff, 2003).

Stimulul cercetãrilor rolului aminelor biogene ĩn declanşarea tulburãrii bipolare 1-a reprezentat descoperirea efectului lor farmacologic ĩn tratamentul depresiei şi maniei. 
Adițional acestor date farmacologice, sistemul de neurotransmitere al aminelor biogene este distribuit extensiv in sistemul limbic, implicat in reglarea somnului, apetitului, trezirii, sexualitãţii, stãrii emoționale precum cea de fricã sau furie.

Imaginea clinicã a tulburãrii bipolare implicã disjuncţiacomportamentalã, a ritmului circadian, a neurofiziologiei somnului şi a reglãrii biochimice şi neuroendocrine din creier. Aceste manifestãri complexe ale tulburãrii sunt ĩn mod indubitabil mediate de o rețea a cãilor de interconexiunea neurotransmițãtorilor. Sistemul de transmitere mediat de monoamine este prin urmare ideal plasat pentru a media asemenea efecte comportamentale complexe, şi prin urmare reprezintã un candidat atractiv pentru a cerceta pato-fiziologia maniaco-depresiei.

\section{Sistemul noradreneric}

În pofida dificultãților metodologice de a evalua funcțiile noradrenergice ale sistemului nervos central la indivizii umani, investigații extinse aratã prezența anomaliilor la nivelul acestor funcții ĩn tulburarea bipolarã.

Studii postmortem au arãtat o creştere a turn-overului noradrenergic ĩn ariile corticale şi talamice ale subiecților cu maniaco-depresie, ĩn vreme ce studii in vivo au gãsit niveluri plasmatice ale noradrenalinei şi ale principalului sãu metabolit, 3-metoxi 4 hidroxifenilglicol (MHPG) mai scãzut la pacienții bipolari depresivi decât la cei unipolari, şi mai crescut ĩn perioadele maniacale ale psihoticilor bipolari. Acelaşi lucru a fost depistat ĩn privința nivelului urinar, existând un nivel scãzut de MHPG la bipolarii depresaţi, iar excreția de MHPG este mai ridicatã ĩn starea maniacalã a acestor pacienți. Similar au stat lucrurile şi ĩn cazul lichidului cefalorahidian, cu nivele crescute de MHPG ĩn timpul maniei şi scãzute ĩn perioadele de depresie.

Alte paradigme ale studiului funcționãrii receptorilor noradrenergici tind sã releve posibilitatea alterãrii sensitivitãţii $\alpha_{2}$ şi $\beta_{2}$ receptorilor adrenergici ĩn maniaco-depresie.

\section{Sistemul serotoninergic}

Existã numeroase date ale studiului lichidului cefalorahidian, ale studiilor endocrinologice, asupra receptorilor serotoninici şi ale recaptãrii acestui neurotransmiţãtor, precum şi ale studiilor farmacologice şi mai recent ale studiilor imagistice ale creierului prin rezonanțã magneticã care demonstreazã implicarea alterãrilor transmisiei serotoninergice ĩn episoadele depresive majore. $\mathrm{Cu}$ toate acestea, cercetãtorii au raportat reducerea nivelului de acid 5 - hidroxi-indol-acetic (5-HIAA) la un subgrup de pacienți, ĩn special la cei care prezintã impulsivitate, agresivitate şi tentative de suicid.

La pacienții maniaco-depresivi, studii asupra lichidului cefalorahidian ĩn privința conţinutului de 5-HIAA au dus la rezultate variabile şi inconsistente. Astfel, linia de bazã a 5-HIAA ĩn lichidul cefalorahidian la pacienții ĩn stare maniacalã, comparativ cu subiecții de control non-depresivi a fost raportatã a fi mai scãzutã ĩn 4 studii, neschimbatã ĩn 9 studii şi mai crescutã ĩn alte 3 studii. Prin contrast, cele mai multe studii au stabilit cã nu existe diferențe ĩntre pacienții cu stare maniacalã fațã de cei cu stare depresivã. 
Studiile au arãtat de asemenea descreșterea legãrii radioligandului la transporterul serotoninic (care preia serotonina din spațiul sinaptic), atât ĩn plachete cât şi ĩn creierul pacienților depresivi. Recent, un studiu PET preliminar a raportat o descreştere a capacitãţii de legare a receptorului 5-hidroxitriptaminei $\left(5-\mathrm{HT}_{1 \mathrm{~A}}\right)$ la nivelul rafeului şi a hipocampului şi amigdalei ĩn creierul pacienţilor depresivi, ĩn particular al depresivilor bipolari sau la cei unipolari care au rude maniaco-depresive.

Unul dintre factorii care ar putea contribui la reducerea legãrii la receptorul 5$\mathrm{HT}_{1 \mathrm{~A}}$ ĩn depresie este creşterea secreției de cortisol, de vreme ce expresia ARNm a receptorului postsinaptic pentru $5-\mathrm{HT}_{1 \mathrm{~A}}$ se aflã sub inhibiția tonicã a stimulãrii receptorului corticosteroidic in anumite regiuni ale creierului. Astfel magnitudinea reducerii densitãţii receptorului pentru $5-\mathrm{HT}_{1 \mathrm{~A}}$ şi a nivelului corespunzãtor al ARNm declanşatã de secreția indusã de stress a glucocorticoizilor la rozãtoare este similarã diferenţelor observate ĩntre depresivi şi indivizii sãnãtoşi.

Modelele de depleție a neurotransmiterii, specificã ĩn acest caz fiind depleția triptofanului, ce determinã scãderea nivelului de serotoninã, reprezintã strategii mult mai directe de investigare a rolului sistemului sertoninergic ĩn tulburãrile afective.

Depleția triptofanului determinã reversia rãspunsului la anumite medicații antidepresive, deşi, depleția ĩn cazul subiecților sãnãtoşi, fãrã o boalã mentalã evidentã şi la pacienții cu depresie care nu au intrat sub medicație, nu s-a constatat nici un fel de intensificare a stãrii depresive.

Studii recente au investigat efectul depleției triptofanului la pacienți eutimici tratați cu litiu şi, ĩn general, nu s-au observat recurențe ale simptomelor. Prin urmare, deşi de multe ori s-a postulat cã litiul ĩşi exercitã efectele benefice printr-o creştere a funcționãrii serotoninergice, studii ale depleției triptofanului sugereazã cã alte mecanisme ar putea fi mult mai importante.

\section{Sistemul dopaminergic}

Multe date experimentale sublinieazã rolul sistemului dopaminergic ĩn tulburãrile afective. Un model preclinic relevant provine din rolul crucial al dopaminei ĩn circuitul neural al comportamentului motivaţional al recompensãrii şi stimulãrii. Pierderea motivației este una din problemele centrale ale depresiei şi ĩntradevãr ahedonia este una dintre caracteristicile definitorii ale melancoliei. Prin urmare, o deficiențã a sistemului dopaminergic apare ca un candidat sustenabil implicat ĩn patofiziologia depresiei.

Cea mai convingãtoare dovadã a implicãrii dopaminei ĩn instalarea depresiei este reducerea acidului homovanilic (HVA) - un metabolit major al dopamniei, din lichidul cefalorahidian.

Existã de asemenea evidenţe pentru o ratã scãzutã a acumulãrii HVA ĩn lichidul cefalorahidian ĩn subgrupe de pacienți depresivi, incluzându-i pe cei cu retardare psihomotorie marcatã versus agitați.

Depresia apare la $40 \%$ din pacienţii cu boala Parkinson idiopatica, şi poate sã preceadã simptomele motorii. Interesant, unele rapoarte de caz prezintã abolirea simptomelor bolii Prkinson pe durata episodului maniacal. 
Legãtura farmacologicã dintre sistemul dopaminergic şi boala maniaco-depresivã sugereazã cã se poate modula dispoziția prin manipularea sistemului dopaminergic. Agoniş̧i dopaminergici apar ca fiind antidepresivi şi sunt capabili sã precipite mania la unii pacienți. Recent, cercetãtorii au utilizat o strategie de depleție catecolaminicã, utilizând AMPT - $\alpha$-metilparatirozinã - inhibitor al tirozin hidroxilazei, la pacienți bipolari ĩ tratament cu litiu. Nu s-au observat efecte de diminuare a depresiei, dar s-a constatat o hipomanie recursivã la un procent semnificativ de pacienți.

Aceste rezultate sunt compatibile cu o semnalizare neorganizatã prin care adaptarea compensatorie la depleția catecolaminei determinã decalibrarea mecanismelor homeostatice. McTavish et all au raportat cã o mixturã tirozin-free a scãzut nivelurile subiective şi obiective ale efectelor psihostimulante ale amfetaminei şi ale scorurilor maniacale. Aceste studii preliminare sugereazã cã disponibilitatea pentru creier a tirozinei atenueazã creşterile patologice ale neurotransmiterii dopaminergice dupã administrarea amfetaminei şi prezumtiv mania.

Ĩn studii neuroimagistice recente s-a cuantificat concentrația VAMAT2 - proteina transportoare monoamincã vezicularã cu DTBZ $-+\left[{ }^{11} \mathrm{C}\right]$ dihidrotetrabenazinã şi PET. Legãtura VAMAT2 ĩn talamus şi creierul ventral al pacienților bipolari era mai ĩnaltã decât la subiecții control.

Tratamentul cronic cu litiu creşte VAMAT2 ĩn cortexul frontal al şobolanilor (singura regiune examinatã), determinând prezumția ca studiile PET de la om sã se fi confundat cu efecte ale tratamentului.

Yahatom et all Au cercetat funcția presinapticã a dopaminei prin mãsurarea captãrii $\left[{ }^{18} \mathrm{~F}\right]$-6fluoro-L-DOPA $\left({ }^{18} \mathrm{~F}\right.$-DOPA) la nivelul striatumului prin studii PET. Nu s-au gãsit diferențe semnificative ĩn captarea ${ }^{18} \mathrm{~F}$-DOPA ĩntre pacienții maniacali şi subiecții control, dar tratamentul cu valproat a redus semnificativ rata de captare a ${ }^{18} \mathrm{~F}$-DOPA.

\section{Sistemul colinergic}

Cele mai multe evidențe ce suportã implicarea sistemului colinergic ĩn tulburãrile afective vin din studii neurochimice, comportamentale şi psihologice ale rãspunsului la manipulãri farmacologice. Aceste studii, desfãşurate ĩn anii 70 , au arãtat un tonus noradrenergic scãzut comparativ cu cel colinergic pe timpul depresiei şi invers pe timpul maniei. Suport a fost dat şi de studii asupra fizostigminei, un inhibitor colinesterazic central ĩn care s-au observat modularea tranzientã a simptomelor ĩn cazuri maniacale şi inducerea depresiei la pacienții bipolari eutimici, stabilizați cu litiu.

$\mathrm{O}$ descreștere a tonusului colinergic pe timpul maniei a fost de asemenea descrisã când necesitãtii crescute ale pilocarpinei - un agonist colinergic, au fost necesare pentru declanşarea unei constricții pupilare: consecutiv, aceastã situaţie a fost crescutã de tratamentul cu litiu sau valproat, adãugând ipoteza cã este posibil ca litiul sã potențeze sistemul colinergic. $\mathrm{Cu}$ toate acestea, rãspunsurile terapeutice ale agenților depresivi şi antimaniacali nu au putut fi corelate cu efecte specifice asupra sistemului colinergic. 


\section{Maniaco-depresia şi semnalizarea intracelularã}

Recent, cercetãrile patofiziologice şi tratamentul tulburãrilor afective şi-au mutat atenția de la neurotransmițãtori sau receptori de pe suprafața celularã la componente ale cascadelor de semnalizare intracelularã.

Numeroase laboratoare au raportat independent anomalii ale subunitãților proteinei $\mathrm{G}$ ĩn tulburarea bipolarã. Studii postmortem ale creierului au arãtat o creştere a nivelului subunitãţii $\mathrm{G}_{\alpha \mathrm{s}}$ corelatã cu o creştere a activitãţii adenilil-ciclazei. Deşi nu existã alterãri genetice la nivelul genei pentru $\mathrm{G}_{\alpha \mathrm{s}}$, sunt postulate alterãri la nivelul altor mecanisme reglatorii transcripționale sau post-transcripționale care ar putea determina nivelul expresiei subunitãţilor proteinei $\mathrm{G}$ şi prin urmare ar rezulta modularea funcționãrii acesteia.

Date preliminare sugereazã de asemenea implicarea sistemului de semnalizare controlat de protein kinaza $\mathrm{C}(\mathrm{PKC})$ ĩn declanşarea unora din simptomele ce apar ĩn maniaco-depresie. Ionii de calciu joacã un rol critic ĩn reglarea sintezei şi eliberãrii neurotransmițãtorilor, excitabilitãţii neuronale, efectelor neuroplastice pe termen lung şi nu este surprinzãtor ca dereglãri de la alte nivele, prin interconexiune, sã se coreleze cu modificãri funcționale la nivelul cascadelor de semnalizare $\mathrm{Ca}^{2+}$-dependente.

Calea de semnalizare a inozitol fosfaţilor, calatã pe IP3 şi DAG, implicatã ĩn numeroase procese intracelulare este de asemenea vizatã de reprecursiuni ale diferitelor cauze declanşatoare ale bolii maniaco-depresive. Dovada implicãrii acestei cãi de semnalizare ĩn patofiziologia maniaco-depresiei rezultã din capacitatea litiului de a bloca aceastã cale de semnalizare, cunoscând capacitatea acestuia de a interveni terapeutic in tulburarea bipolarã.

Recent, P. Klein a descoperit implicarea proteinei GSK-3 $\beta$ ĩn mecanismul de acțiune al litiului la nivel celular. Cunoscând o parte din detaliile complexitãții proceselor modulate prin semnalele angajate pe cale de transmitere coordonatã de aceastã proteinã, printre care meritã menționat ritmul circadian, nu putem exclude implicarea funcționãrii acesteia in instalarea unora dintre simptomele specifice maniaco-depresiei.

Interconexiunea cãilor de semnalizare şi aspectul polifactorial al maniaco-depresiei sugereazã complexitatea mecanismelor implicate şi afectate ĩn patofiziologia cestei tulburãri psihiatrice.

\section{Aspecte genetice ale maniaco - depresiei}

Studii efectuate pe gemeni, ĩn cazul unor adopții şi ĩn familii cu mai mulţi indivizi bipolari aratã influența etiologicã a unor factori multipli de mediu şi genetici. Concordanța ĩntre gemenii identici (monozigotici) variazã ĩntre 61 şi 75\%, iar riscul morbiditãţii la rudele de gradul I se situeazã ĩntre 1,5 şi 15,5\%. Aceste date sugereazã cã tulburarea bipolarã are o heritabilitate semnificativã, cu un mod de transmitere nonMendelian. Se poate prezuma cã apariţia bolii se coreleazã cu prezența unor gene care genereazã vulnerabilitate şi care la interacțiunea cu factori de mediu pot detrmina expresia fenotipicã a maniaco-depresiei. 
Studii moleculare şi farmacologice au permis selectarea genelor şi a regiunilor genomice potențial implicate ĩn susceptibilitatea la tulburarea bipolarã. Gene codificatoare ale receptorilor sau ale unor enzime ale sistemului mono-aminergic reprezintã candidaţi calificați pentru studiile asociaționale, de vreme ce produşii acestor gene au calitatea de țintã pentru diferitele substanțe terapeutice utilizate ĩn tratamentul tulburãrilor afective.

Studii de linkare - permit poziţionarea regiunilor cromozomiale potențial asociate cu incidența maniaco-depresiei şi ulterior identificarea genelor prezente ĩn aceste regiuni. Studiile post-mortem ce verificã profilul expresiei genice ĩn creierul indivizilor maniacodepresivi, permit identificarea altor posibile gene implicate in patofiziologia acesteia. Ulterior, studii farmacogenomice pot stabili setul de variaţie al profilului expresiei genice caracteristic subtipurilor etiologice ĩn funcție de rãspunsul farmacologic.

Diferitele mecanisme genetice pot fi implicate ĩn etiopatogenia maniaco-depresiei, cum ar fi heterogenitatea alelicã a genelor (locilor), epistazia, mutaţia dinamicã ce poate fi corelatã cu fenomenul de ,anticipare”, imprintingul, sau mutaţia unor gene mitocondriale.

Studii citogenetice. Anumite regiuni genomice potențial asociate cu maniacodepresia au fost identificate prin observarea co-segregãrii anumitor anomalii cromozomiale cu maniaco-depresia prezentã la mai mulți indivizi ditr-o familie. Translocarea balansatã este principala anomalie gãsitã ĩn aceste cazuri.

Mai multe regiuni au fost identificate ca locusuri genice susceptibile pentru instalarea maniaco-depresiei. Craddack şi Owen, analizând rapoartele anterioare privind anomaliile cromozomiale asociate cu tulburarea bipolarã, au identificat 4 regiuni de interes, frecvent raportate: 11q21-25, 15q11-13, cromozomul 21 şi Xq28.

Alte anomalii cromozomiale sugerate ca fiind situri potenţial asociate cu tulburarea bipolarã sunt: 8p21 şi 15q22-24, 18q23, 18p11.3 şi 18p21.1, 9p24 şi 11q23.1, 1q42.1 şi 11q14.3.

Anomaliile cromozomiale gãsite la subiecții cu tulburãri mentale pot fi ĩn general considerate ca semnificative dacã alterarea este rarã, raportatã ĩn special ĩn segregare cu schimbãri comportamentale, sau când alterãrile apar ĩn regiuni indicate de studii de linkare ca fiind asociate cu tulburãrile afective. Prin urmare, se sugereazã cã indivizii cu istorie familialã semnificativã, alterãri cognitive şi/sau anomalii congenitale, ar trebui incluşi ĩn investigații cariotipice.

Repercursiunea alterãrilor structurale genomice ĩn dezvoltarea tulburãrilor afective depind de locul ĩn care ele se produc. Când disrupția apare ĩntr-o singurã secvențã genicã, produsul de transcripție al genei implicate este afectat, ca de altfel toate procesele celulare dependente de acest produs. $\mathrm{Cu}$ toate acestea, repercursiunile fiziologice depind de importanța sau exclusivitatea acestui produs genic ĩn metabolismul celular şi ĩn cãile de semnalizare.Dacã regiunea implicatã nu este o secvențã genicã, repercursiunea este mult mai puţin intensã, deşi secvenţele ne-codificatoare pot influenţa expresia şi procesul de transcripție al segmentelor ĩnvecinate. 
Studii asociative cu gene candidate. Studiile de asociere sunt o alternativã pentru studiul genelor implicate ĩn boli complexe cu mecanism de transmitere necunoscut. Gene candidate ĩn mod natural utilizate inițial ĩn studiile de asociere au fost cele legate de sistemul monoaminergic. Studiile nu au fost ĩnsã concudente, prezentând numeroase rezultate conflictuale pentru genele investigate.

Recent, studiile sunt focusate asupra genei pentru GSK-3 $\beta$ cu rol important ĩn dezvoltare şi ĩn viața celularã. Litiul inhibã direct aceastã enzimã, blocând procesele apoptotice. Un studiu recent a descoperit o asociere pozitivã ĩntre polimorfismul -5OT/C al alelei $\mathrm{T}$ al genei GSK-3 $\beta$ cu instalarea timpurie a tulburãrii bipolare.

Alela $\mathrm{G}$ a polimorfismului A196G al factorului neurotrofic derivat din creier BDNF prezintã o transmitere preferențialã la pacienții bipolari, reprezentând un important locus de risc pentru maniaco-depresie.

Studii de sociere cu gene ale unor boli ce reprezintã factori de risc pentru tulburarea bipolarã. Anumite boli ereditare sunt ĩn general ĩnsoțite de tulburãri mentale.

Sindromul Wolfram are o moştenire autosomal recesivã şi este caracterizat prin prezența diabetului şi a atrofiei optice. Gena WFS1, a cărei mutații sunt responsabile de sindrom, este situatã in regiunea cromozomialã $4 p 16$. Studiile de asociere în tulburarea bipolarã au indicat, de asemenea, această regiune. În consecinţă, mutaţii ale genei WFS1 au fost examinate la indivizii maniaco-depresivi. Furlong et all au observat o frecvență mai mare a mutaţiei Ala559Thr în tulburãrile afective. Alte grupuri nu au putut să identifice alte asocieri cu mutaţiile studiate. Pe langa aceasta, proteina codificată de această genă pare a interacționa cu ADN-ul mitocondrial, care este altã regiune genomicã potenţial asociatã cu tulburarea afectivã.

Boala Darier are o moştenire dominant autosomalã şi se caracterizeazã prin modificări dermatologice (acantolizã şi keratinizare anormalã), fiind frecvent asociatã cu tulburări mintale. Gena ale cărei mutații duce la apariția acestei boli este situatã in regiunea cromozomialã 12q23-24,1 şi codifică enzima Ca-ATP-aza reticolului endoplasmatic. Având în vedere raportul de co-segregare ĩn familiile cu tulburãri bipolare şi modificările calciu-dependente, se sugereazã cã aceaste mutaţii genice pot avea efecte pleiotrope pe piele şi creier. Jacobson et all au studiat asocierea dintre mutaţiile observate în această genă la pacienții maniaco-depresivi care au facut parte din mai multe pedigre-uri ĩn legăturã cu markeri cromozomiali din aceeaşi regiune cu rezultate pozitive.

Prezența tulburãrilor bipolare într-o frecvență semnificativ mai mare decât în populația generală apare, de asemenea, în sindromul velo-cardio-facial, cauzat de o micro-deleție în cromozomul 22q11, care duce la mai multe efecte somatice, de învăţare şi tulburări de comportament. Sa constatat că $64 \%$ dintre aceşti pacienți îndeplinesc criteriile pentru spectrul bipolar şi sugerează acest locus ca fiind implicat în sensibilitate la maniaco-depresie.

Repetari de trinucleotide: Anticiparea, un fenomen în care o boală apare progresiv, la o vârstă mai timpurie, în generații succesive, poate explica devierile în 
transmiterea Mendelianã observate în unele boli ereditare. Repetitii în secvența de trinucleotide sunt corelate cu anticiparea. Aceste secvenţe sunt instabile şi se pot extinde în mărime între generaţii şi, astfel, duc la o înrăutăţire a simptomelor. Aceste mutaţii pot explica discordanța de transmitere a tulburãrii afective între gemenii monozigotici. Deşi fenomenul de anticipare poate fi cauzat de factorii de mediu, observarea apariţiei sale în rândul pacienților maniaco-depresivi a condus la investigarea extinderii repetarilor CAG/CTG în boala afectivã. Printre expansiunile CTG/GAC investigate, frecvente la pacienții bipolari au fost cele depistate ĩn alelele situate in regiunea cromozomialã 18q21.1, şi alelele ERDA1, din regiunea cromozomialã 17q21.3.

Imprinting - ul. Factori epigenetici duc la modificări care reglementează activitatea unor gene. Înțelegerea acestor mecanisme permite o mai bună evaluare a modelelor de transmitere ereditarã, cum ar fi discordanțele fenotipice între gemenii monozigotici, în vârsta de risc pentru apariția bolii sau diferențele clinice între sexe. Unul dintre mecanismele utilizate în acest control este imprintingul.

Imprinting -ul se referă la un model de transmitere ereditarã non-Mendelian în care fenotipul depinde de originea parentalã a alelei asociate cu boala. Se remarcã faptul că pacienții bipolari au o frecvență mai mare a mamelor afectate, decât a taţilor printre strămoşi. Unele aspecte ale moştenirii genetice pot determina acest model. Moştenirea mitocondrială poate explica transmiterea fenotipului matern. Disfuncția mitocondrială în maniaco-depresie a fost sugeratã de mai multe studii. Studii de asociere indicã regiunea cromozomialã 18p11 sugerând mecanismul de metilare a ADN-ului ca un mediator de imprinting în aceste cazuri. Alte constatări sugerează o preferințã paternă de transmitere a alelei dopa-decarboxilazei în maniaco-depresie.

\section{Profilul expresiei genice}

Noile tehnologii în genetica moleculara au permis caracterizarea profilului genic de exprimare a fiecărui organ. Aplicarea acestor tehnici post-mortem pe creier la indivizii cu maniaco-depresie şi alte boli din psihiatrie a devenit un important instrument de identificare a genelor implicate în etiologia şi patofiziologia acestor boli.

Comparații intre creierul pacienților bipolari şi indivizii de control pot fi folosite pentru a identifica reducerea TGF- $\beta$ şi creşterea precursorilor caspazei- 8 şi erbB- 2 , în cortexul pre-frontal. Studii post-mortem au evidențiat modificările nivelurilor mai multor mesageri intracelulari, cum ar fi PKA şi PKC, ERK / MAPK.

Încercând sã determine gene specifice tulburãrii bipolare sau altor tulburări mintale, cum ar fi schizofrenia şi depresiile majore, Iwamoto et all au observat la pacienții bipolari o tendință de a diminua expresia genelor care codifică unele proteine de membrana, ionice şi transport, şi creşterea în expresia genelor legate de rãspunsul la stress, cum ar fi HSPF1 (proteine de şoc termic 40). Alte modificări moleculare, au fost identificate pentru neuropeptidele $\mathrm{Y}, \mathrm{ARNm}$ ale căror niveluri sunt reduse în cortexul frontal al subiecților bipolari, de receptori de proteine $G$ kinase 3 (GRK3), ale căror niveluri sunt reduse la un subgrup de pacienți. 


\section{Ritmurile circadiene şi tulburarea bipolarã}

Numeroase cercetări arată că existã un ceas genetic care controleaza ritmurile circadiene ale organismului şi care poate fi integral implicat în dezvoltarea tulburãrii bipolare. Ritmurile circadiane includ trezirea şi odihna zilnicã, un ritm zilnic al senzaţiilor de foame şi sete şi multe alte procese, cum ar fi temperatura corpului, nivelul de hormoni, presiunea sângelui şi a activităţii cardiace.

Existã evidențe cã litiul poate întârzia ritmicitatea circadianã, adică, o aduce inapoi la normal ĩn cazul maniaco-depresivilor. Mult mai recent, sa descoperit că fiecare individ are un pacemaker celular (in nucleul suprachiasmatic al hipotalamusului la mamifere) sistem circadian care răspunde la litiu. $\mathrm{Cu}$ alte cuvinte, efectele litiului nu sunt la nivel de sistem (de exemplu, interferența cu comunicarea celulă-celulă), ci la nivel de celulã. Aceasta sugerează că litiu poate acționa asupra unui anumit ceas genetic.

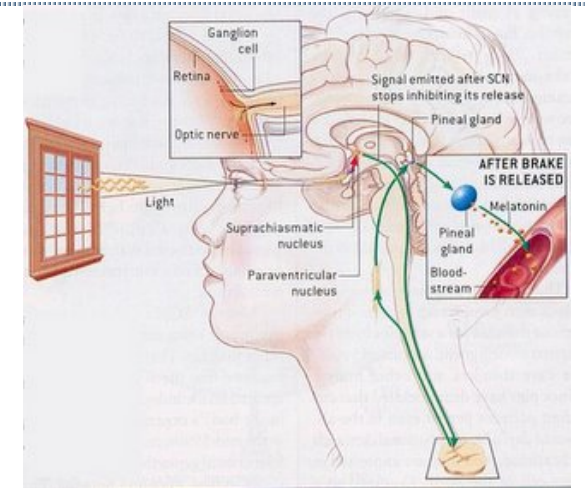

Figura 11. Locacizarea centrului de control al ritmului circadian

Ceasul genetic țintă pentru acțiunea litiului nu este limitat la mamifere, sau vertebrate, după cum litiu are aceleasi efecte pe ritmurile circadiene la alte organisme, inclusiv Drosophila melanogaster. Astfel, este probabil ca genele componente ale ceasului biologic să aibă corespondenți la vertebrate şi nevertebrate, ceea ce îngustează lista de candidați.

Genele implicate în generarea ritmurilor circadiane pot fi clasificate în genele ceasului de bază şi ĩn gene asociate acestui ceas. Nucleul ceasului genetic este format din mai mulți factori de transcriere. Proteinele codificate pot inhiba sau stimula transcrierea altor gene ale ceasului de bază şi pot reglementa expresia altor gene din aval care controlează rezultatele functionale ale celulei, stabilind, de exemplu, când să elibereze, sau nu, un hormon, când să doarmă, sau când să se trezească, etc.) Dacă nu ar exista decât genele ceasului de bază, ciclul circadian ar dura numai câteva ore. Acesta este timpul necesar pentru toti jucatorii să comute pe off si invers. În scopul prelungirii ciclului cât mai aproape de 24 de ore, alte gene sunt asociate ceasului biologic. Podusele lor acționează în calitate de modulatori - ele pot adăuga sau elimina grupuri de fosfat la genele ceasului de bază, inhibând sau stimulând expresia genelor respective. Degradarea 
nucleului proteic al ceasului are loc fie spontan, fie la primirea unui semnal că retinele au perceput lumina, etc.

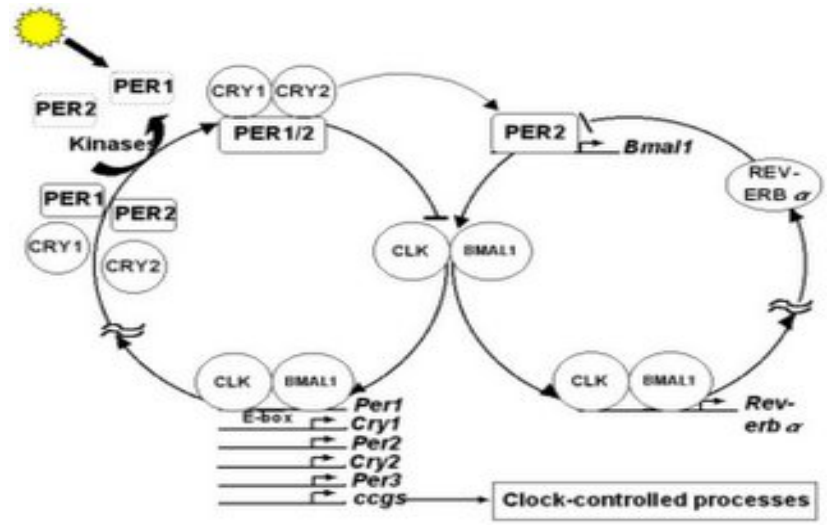

Figura 12. Ceasul genetic circadian al mamiferelor

Aici este o schematizare a ceasului circadian al mamiferelor. Schema este similară şi la alte organisme, cu unele modificări (animatie). Genele numite Perioadăa, Cryptochrome, clock şi Bmal 1 (sau MOP) sunt principalele elemente ale ceasului genetic la mamifere.

$\mathrm{Cu}$ câțiva ani în urmă, s-a ajuns la ipoteza că genele implicate în mecanismul ceasului biologic sensibil la litiu nu sunt elementele principalele ale ceasului biologic, ci doar unele dintre genele accesorii: Glycogen sintetaz kinazei-3ß (GSK3), care, la rândul ei, acționează asupra Rev-Erb, care, la rândul său acționează asupra Bmal. Receptorul nuclear Rev-erb $\alpha$ este o componentă critică litiu-senzitivă a ceasului circadian.

Litiu inhibă GSK3 $\beta$. GSK3 $\beta$ protejează, în mod normal, Rev-Erb de la distrugere. Rev-Erb inhibă în mod normal expresia genei Bmal a ceasului principal (şi, de asemenea, probabil a genei Per). Fără Rev-Erb, Bmal și Perioada se pot exprima din nou.

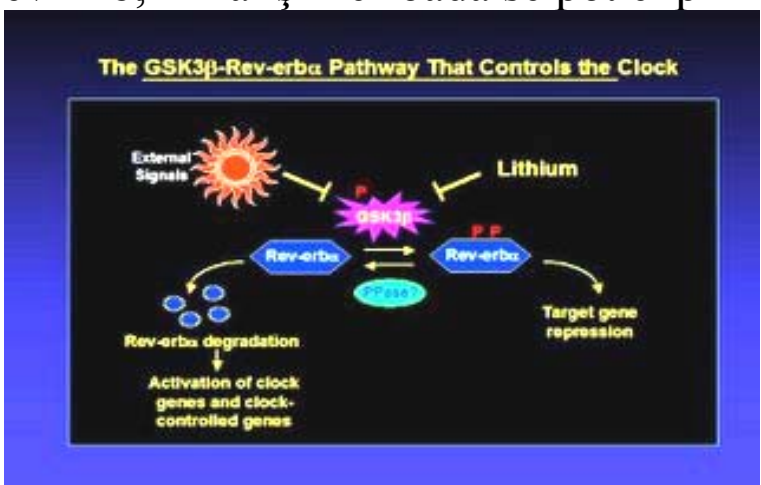

Figura 13. Schema intervenției litiului asupra ceasului circadian

Probabil acest lucru înseamnă că ceasul biologic este într-un fel "blocat" ĩn maniaco-depresie. Probabil Rev-Erb se acumulează şi opreşte ceasul. Litiul ajutã indirect la degradarea Rev-Erb, permițând astfel continuarea ciclului circadian. 


\section{Modelarea matematicã a psihezei bipolare II printr-un oscilator armonic}

Psihoza bipolarã de tip II are un nivel ridicat de transmitere ereditarã, raportându-se faptul cã pentru un individ suferind de psihozã maniaco-depresivã existã 35\% şanse sa aibã ĩn descendențã copii cu aceeaşi tulburare.

Psihiza manico-depresivã de tip II se caracterizeazã prin alternanţa unor episoade hipomaniacale cu episoade depresive majore. Datoritã periodicitãţii de manifestare a fazelor hipomaniacale şi a celor depresive, ĩn cazul ĩn ca nu s-au utilizat tratamente pentru a ameliora aceste simptome, modelarea periodicitãții schimbãrilor afective ale dispoziției pacienţilor se poate realiza prin utilizarea modelului teoretic al unui oscilator armonic amortizat negativ, a cãrui ecuaţie este de forma:

$$
\ddot{x}-\alpha \dot{x}+\omega^{2} x=0,
$$

unde $x$ reprezintã starea emoționalã, $\dot{x}$ este rata schimbãrii dispoziției ĩntre hipomanie şi depresie, iar $\alpha>0$ şi $\omega$ sunt parametrii ecuației.

Ĩncă de la sfâsitul secolului al XIX-lea, Henry Poincaré considerat părintele dinamicii neliniare, a subliniat faptul că turbulențele si comportarea neliniară, sunt de fapt caracteristici inerente sistemelor ĩn care se produc interacțiuni neliniare. Mai mult decât atât, el a demonstrat că, chiar şi ĩn cazul sistemelor simple, cu puţine grade de libertate, dar care includ neliniarităţi, se poate constata o evoluție complicată şi care, ĩn timp, devine imprevizibilă.

Un sistem este neliniar dacă este descris de ecuații neliniare, cu alte cuvinte dacă variabilele dinamice ce descriu proprietăţile sistemului (coordonatele, viteza, presiunea etc.) apar ĩn ecuații sub forma unor temeni neliniari.

O funcție este liniară dacă are proprietatea:

$\mathrm{f}(\mathrm{x}+\mathrm{y})=\mathrm{f}(\mathrm{x})+\mathrm{f}(\mathrm{y}) \mathrm{f}(\mathrm{ax})=\mathrm{af}(\mathrm{x}), \forall(\mathrm{x}, \mathrm{y}, \mathrm{a})>0$.

Existã situații ĩn care evoluția pe termen lung a unui sistem converge cãtre o curbã ĩnchisã. Aceastã curbã ĩnchisã este un atractor, numit ciclu limitã, dacã atunci când $t$ $\infty$, traiectoriile sau se apropie asimptotic, respectiv se ĩndepãrteazã de ea. Ciclurile limitã sunt caracteristice fenomenelor periodice.

Poincaré şi Bendixson au demonstrat o teoremã prin care afirmã cã, pentru sistemele bidimensionale, ĩn cazul ĩn care existã regiuni finite din care traiectoriile pornesc şi se ĩntorc existã douã posibilitãţi pentru comportarea pe termen lung:

1. traiectoriile sã se apropie de un punct fix;

2. traiectoriile sã se apropie de un ciclu limitã

În situaţia ĩn care ciclurile limitã existã şi se poate identifica un interior şi un exterior al acestora, nici o traiectorie din interior nu poate traversa aceastã curbã ĩnchisã, dupã cum nici o traiectorie situatã ĩn exterior nu poate intersecta curba pentru a pãtrunde ĩ interior. Aceastã proprietate este datoratã faptului cã traiectoriile din spaţiul fazelor nu se pot intersecta. 
Lucrãrile de specialitate indicã douã modele matematice pentru modelarea psihozei bipolare de tip II, reprezentate de: oscilatorul van der Pol cu forțã autonomã şi modelul oscilatorului Liénard.

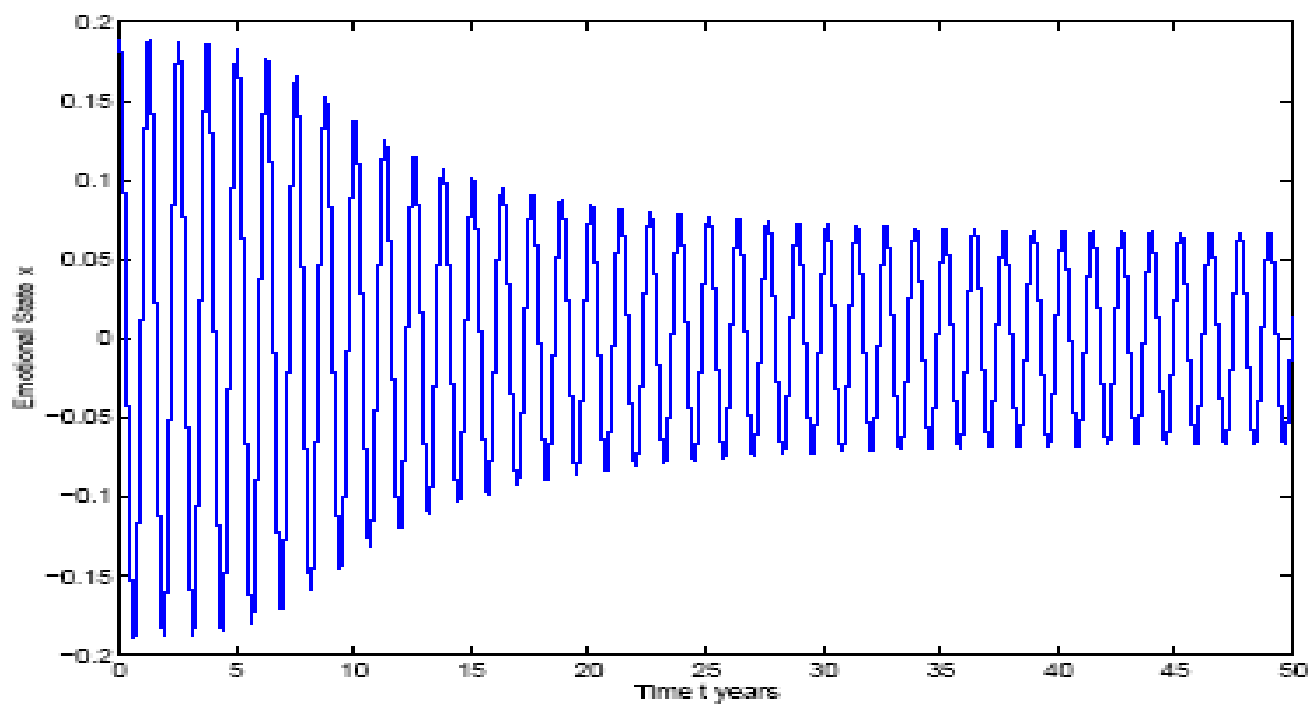

Figura 14. Modelarea matematicã oscilatorie a evoluției periodice a fazelor maniacale şi depresive ale unui pacient tratat corespunzãtor

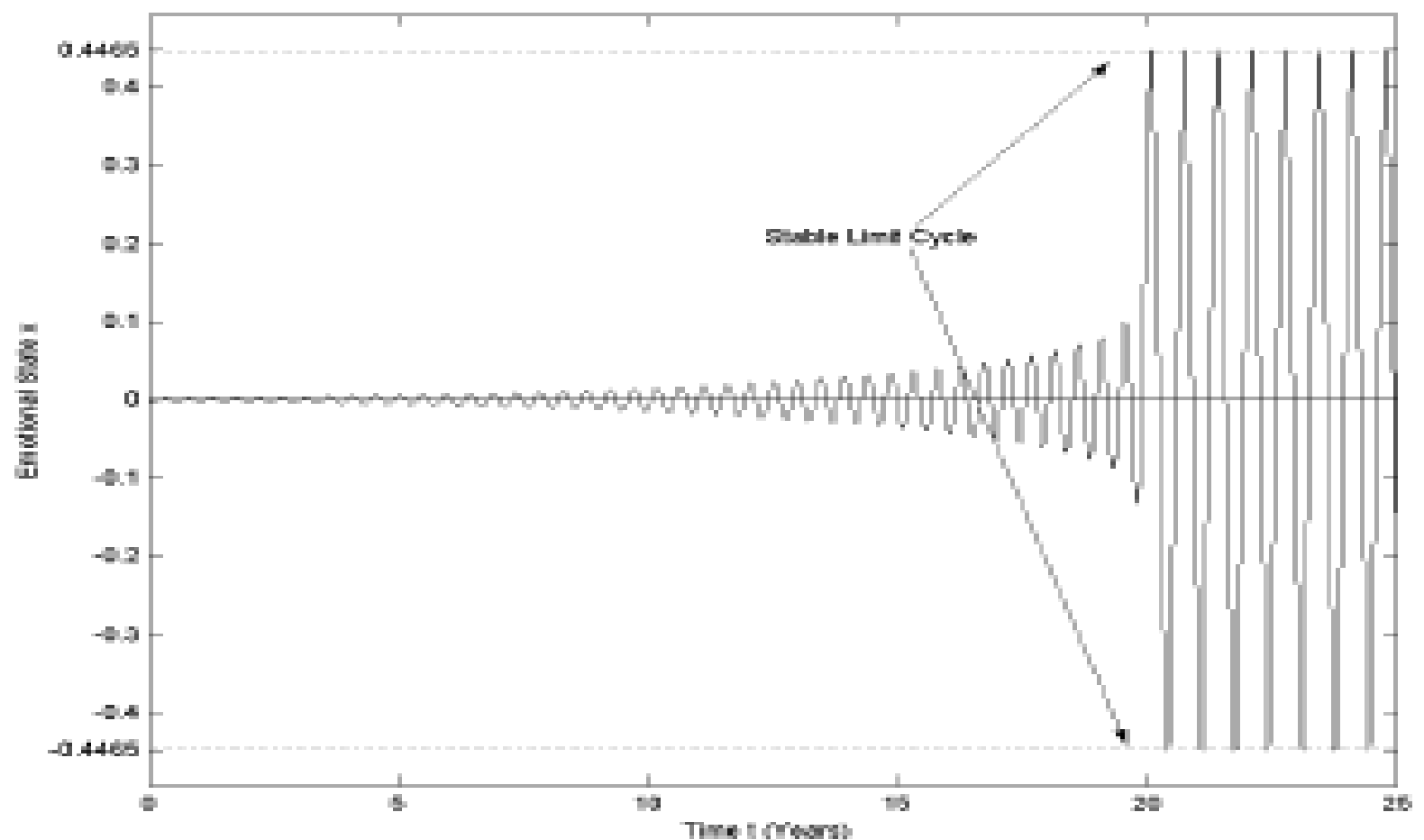

Figura 15. Modelarea matematicã oscilatorie a evoluției periodice a fazelor maniacale şi depresive ĩn cazul agravãrii maniaco-depresiei 


\section{Diagnostic}

Studii clinice indicã faptul cã medicii care nu sunt psihiatri înregistreazã frecvent eşecuri în recunoaşterea sau diagnosticarea corectã a pacienților cu tulburãri afective. Tulburãrile afective trebuie sã fie întotdeauna o parte a diagnosticului diferenţial de câte ori acuzele pacientului implicã vreun simptom din spectrul depresiv.

\section{Criteriile diagnostice pentru episoodul depresiv major*:}

A. Cel puțin cinci din urmãtoarele simptome au fost prezente în cursul aceleaşi perioade de 2 sãptãmâni şi reprezintã o schimbare de la funcționalitatea anterioarã. Cel puțin unul din simptome este (1) dispoziție depresivã sau (2) pierderea interesului sau plãcerii. ( $\mathrm{Nu}$ se includ simptomele care sunt din cauza unei afecţiuni fizice, ideile delirante sau halucinațiile fãrã legãturã cu afectivitatea, incoerența sau asociațiile greşite).

1. Dispoziție depresivã (poate fi dispoziție iritabilã la copii şi adolescenți) cea mai mare parte a zilei, aproape în fiecare zi, indicatã subiectiv sau de observațiile celorlalți.

2. Diminuarea pronunţatã a interesului sau plãcerii pentru toate sau aproape toate activităţile în cea mai mare parte a zilei, aproape în fiecare zi (dupã cum indicã observarea subiectivã sau de cãtre cei din jur a apatiei prezente frecvent).

3. Pierderea sau câştigul semnificativ în greutate în afara dietei (mai mult de 5\% din greutatea corporalã pe lunã) sau scãderea sau creşterea apetitului aproape în fiecare zi (la copii se are în vedere câştigul minim sau nul în greutate).

4. Insomnie sau hipersomnie aproape în fiecare zi.

5. Agitaţie sau retardare psihomotorie aproape în fiecare zi (observate de ceilalţi, nu numai sentimente subiective de nelinişte sau lentoare).

6.Fatigabilitate sau pierdere a energiei aproape în fiecare zi.

7.Sentimente de devalorizare sau de vinovãţie excesivã sau inadecvatã (nu numai antireproş sau vina de a fi bolnav).

8. Abilitate diminuatã de a gândi sau de a se concentra sau indecizie, aproape în fiecare zi (din relatarea subiectivã sau observațiile altora).

9. Idei recurente legate de moarte (nu numai teamã de moarte), ideație suicidalã recurentã fãrã un plan specific sau o tentetivã de suicid sau un plan de sinucidere.

B.1. Nu se poate stabili cã un factor organic a iniţiat şi menţinut tulburarea

2. Tulburarea nu este o reacție normalã la moartea cuiva iubit (doliu necomplicat**)

C. În nici un moment în cursul tulburãrii n-au fost idei delicvente sau halucinații pentru o perioadã mai lungã de 2 sãptãmâni în absența simptomelor afective pronunțate (adicã înainte sã se dezvolte simptomele afective sau dupã ce acestea s-au remis)

D. Nu se suprapune peste schizofrenie sau tulburare schizofreniformã, delir sau tulburãri psihotice.

* Sindromul depresiv major este definit prin criteriile A de mai sus.

** Preocupãri morbide cu devalorizare, ideație suicidarã, scãdere funcționalã marcatã sau încetinire psihomotorie, sau prelungirea duratei sugereazã durere complicatã de depresie majorã. 


\section{Criterii diagnostice pentru episodul maniacal*:}

A. O perioadã distinctã de persistentã dispoziție anormalã de euforie, expansivitate sau iritabilitate

B. În cursul perioadei de tulburare a dispoziției, cel puțin trei din urmãtoarele simptome au persistat (patru dacã dispoziția este numai iritabilã) şi sunt prezente într-un grad semnificativ

1. Creşterea autostimei sau grandoare;

2. Nevoie scãzutã de somn, ex. se simte odihnit numai dupã trei ore de somn;

3. Mult mai vorbãreț decât obişnuit sau tendința de a vorbi continuu;

4. Fugã de idei sau experiențã subiectivã de accelerare a gândurilor;

5. Lipsã de concentrare, adicã atenția este atrasã prea uşor de stimuli externi neimportanți sau irelevanți;

6. Amplificarea activitãții direcționate spre un țel (socialã, la muncã sau la şcoalã, sau sexual) sau agitație psihomotorie;

7. Implicare excesivã în activitãţi plãcute care au un potenţial ridicat de consecinţe dureroase, ex. Persoana se angajeazã fãrã rețineri în petreceri, imprudențe sexuale sau investiții prosteşti în afaceri.

C. Tulburare a dispoziției suficient de severã pentru a determina diminuarea marcatã a activitãții profesionale sau a activitãților sociale obişnuite sau a relațiilor cu ceilalţi sau necesitând spitalizare pentru a preveni vãtãmarea personalã sau a celorlalţi

D. În nici un moment din cursul tulburãrii n-au fost prezente idei delirante sau halucinații pentru o perioadã mai lungã de 2 sãptãmâni în absența simptomelor afective proeminente (adicã înainte ca simptomele afective sã se dezvolte sau dupã ce acestea s-au remis)

E. $\mathrm{Nu}$ se suprapune peste schizofrenie sau tulburare schizofreniformã, delir sau tulburãri psihotice

F. Nu se poate stabili cã un factor ortanic a iniţiat şi menţinut tulburarea**

* Un sindrom maniacal este definit prin cuprinderea criteriilor A,B şi $\mathrm{C}$ de mai sus. Un sindrom hipomaniacal este definit prin cuprinderea criteriilor A şi $\mathrm{B}$, dar nu şi $\mathrm{C}$, adicã fãrã diminuarea marcatã

** Tratamentul antidepresiv somatic (ex.medicamente, terapie electoconvulsivantã) care aparent precipitã o tulburare a dispoziției nu trebuie considerat un factor etiologic organic. 


\section{Evoluția clincã a maniaco-depresiei}

Vârsta de risc pentru tulburãrile bipolare variazã în limite largi, de la 6 sau 7 ani la peste 65 ani; vârful vârstei de instituire a primului episod este de 19 ani. Tulburãrile bipolare sunt uşor mai frecvente la femei comparativ cu bãrbaţii (1,3:1). Bãrbaţii au mai multe episoade maniacale decât depresive.

Debutul simptomelor se poate institui în ore, dar de regulã în zile sau sãptãmâni şi poate sã înceapã fie cu un episod maniacal, fie cu unul depresiv. Mai mult de jumãtate din primele episoade sunt maniacale şi aproximativ 60 procente din acești pacienţi au o direcție predominant maniacalã, în timp ce treimea rãmasã, manifestã inițial episoade depresive.

Studii clinice asupra unor pacienți cu tulburare bipolarã netrataţi au arãtat în medie prezența a 9 episoade diagnosticabile maniacale sau depresive de-a lungul vieții (limitele se situeazã între 2 şi peste 20). Modelul tipic este cã lungimea ciclului, mãsurat de la instituirea primului episod pânã la instituirea urmãtorului episod, scade, iar numãru episoadelor creşte de-a lungul timpului. De exemplu, la pacienţii cu tulburare bipolarã netrataţi, timpul dintre primul episod şi episodul secund este în medie între 3,5 şi 4 ani, între episodul secund şi cel terț este de aproximativ 2 ani şi între episodul al treilea şi al patrulea undeva între 12 şi 18 luni. Durata episodului netratat este între 4 şi 13 luni şi în medie este de aproximativ 8,5 luni, dar poate fi mai scurtã în cursul fazelor maniacale (adicã boala netratatã tinde sã se înrãutãțeascã în timp, scoțând în relief importanța intervenției).

Un subgrup mic de pacienți cu tulburare bipolarã manifestã foarte rapid modele ciclice de la patru episoade pe an la episoade la fiecare 24 ore. Optzeci de procente dintre cei cu cicluri rapide sunt femei şi a fost sugeratã şi o relație cu hipofuncţia tiroidianã. De asemenea, încã controversatã este evidenţa cã unii pacienți cu cicluri rapide pot fi asociați cu tratamentul anterior cu antidepresive triciclice şi cã situația poate fi controatã efectiv numai dupã întreruperea triciclicelor şi începerea tratamentului cu substituenții tiroidieni şi litiu.

Intensitatea bolii pe durata întregii vieți în toate tulburãrile bipolare este mai mare decât în tulburarea depresivã majorã recurentã; înainte de descopereirea litiului, prognosticul pe termen lung era de rãu augur. Pacienții bipolari au mai multe episoade semnificative de boalã, necesitã multiple spitalizãri, petrec mult timp în spital de-a lungul vieții, au probabilitate mai mare de a divorța, îşi pierd slujbele, şi netratați au un risc crescut de suicid.

$65 \%$ din psihozele afective evolueaza unipolar, in special fazele depresive; $30 \%$ bipolar, iar 5\% - doar ca episoade maniacale. Tulburarea bipolara evolueaza in general cu un numar mare de faze, a caror durata devine din ce in ce mai scurta. $\mathrm{Cu}$ cât boala este de mai lunga duratã, cu atat mai mult creşte frecvența fazelor, iar intervalele de linişte simptomatologica se reduc. 
Dupa fiecare faza se produce de regula o remisie completa. La circa $10 \%$ din depresiile unipolare endogene urmeaza o faza hipomaniacalã şi analog.

Netratate, episoadele depresive şi maniacale dureaza ĩn medie pânã la 12 luni. Fazele maniacale sunt ĩn medie mai scurte. $\mathrm{O}$ data cu ĩnaintarea ĩn vârsta, fazele depresive dureaza mai mult, eventual prin asociere cu factori organici, şi au tendinţa de cronicizare. Episoadele depresive debuteaza de obicei insidios, pe când cele maniacale debuteazã fulminant - timp de cateva ore sau zile. $25 \%$ din depresii evolueaza monofazic, $75 \%$ recidiveaza. La tulburarea bipolara trebuie luate ĩn calcul, ĩn medie, şase episoade ĩn cursul vieții.

La distimii existã riscul de a evolua ĩn timpul vieții spre depresie majorã (25\%), asa-numita „dublã depresie”. În cazul ciclotimiei existã de asemenea riscul de a evolua spre tulburãri bipolare (45-50\%).

Tulburarea bipolarã reprezinta 5\% din totalul tulburãrilor afective.

Din punct de vedere epidemiologic, nu exista la tulburarea bipolarã diferențe intersexuale, ĩn ceea ce priveşte rata de morbiditate, raportul bãrbați/femei fiind de 1:1. Vârsta medie de ĩnbolnavire la tulburarea bipolarã este situatã ĩntre 20 şi 35 de ani. Tulburarea bipolarã este mult mai rarã decât cea recidivantã unipolarã depresivã. Prevalența pe timpul de viaţa se situeaza intre 0,4 si $1,6 \%$.

Cea mai serioasã complicație in cazul tulburãrii afective bipolare este suicidul, prin care mor ĩn Germania 15-20\% dintre pacienții cu acest diagnostic, dupa care urmeazã abuzul de substanțe psihotrope, dependența de alcool şi de benzodiazepine.

Comorbiditatea este ĩnregistratã cu urmatoarele boli:

- tulburarea anxioasã: fobii $(6 \%)$, tulburare de panicã, tulburare anxioasã generalizata $(40-50 \%)$;

- tulburare de personalitate;

- dependența de substanțe psihotrope sau alcool (de exemplu sub forma de automedicație). 


\section{Morbiditate, mortalitate şi comorbiditate}

Morbiditate Existã dovezi cã tulburãrile afective au un impact major asupra stãrii sãnãtãţii şi calitãții vieții. Pe un eşantion larg din pacienții din ambulator (peste 22000 subiecți) s-a arãtat cã cei cu tulburare depresivã majorã şi cei cu tulburare distimicã contribuie la incapacitate în activitatea fizicã, socialã şi profesionalã mai mare decât cei $\mathrm{cu}$ hipertensiune, diabet, boli pulmonare cronice sau artrite. Numai pacienții cu boalã arterialã coronarianã acutã au avut mai multe zile de inactivitate în cursul lunilor precedente decât cei cu tulburãri depresive.

Mortalitate Sunt peste 32000 de sinucideri în fiecare an în Statele Unite. Sinuciderea este în ceastã țarã a opta cauzã de deces pentru adulți. S-a estimat cã 80 procente din sinuciderile complete sunt legate de tulburãrile afective. Rata tentativelor de suicid de-a lungul vieții pentru tulburãrile depresive majore este de 14,3 procente şi pentru tulburãrile distimice este de 14,1 procente. Aproximativ 15 procente din pacienții cu tulburãri depresive majore recurente mor prin sinucidere.

Pacienții cu tulburãri bipolare au o ratã crescutã de deces prin sinucidere, totalizând de 15 pânã la 20 ori mai multe decese fațã de populația generalã. 15 pânã la 20 de procente dintre pacienții afectați au tentative de suicid, mai frecvent femeile decât bãrbaţii; de asemenea, bãrbații au probabilitate mai mare de reuşitã. Înainte de terapia cu litiu, peste 20 procente din pacienții maniacali mureau în spital, iar aproximativ douã treimi din aceştia mureau din cauza "epuizãrii".

Comorbiditatea cu tulburãrile induse de abuzul de substanțe Prevalența ridicatã a tulburãrilor afective combinatã cu insuccesul în recunoaşterea şi tratamentul lor probabil contribuie în mod neregulat la ratele ridicate la care abuzul de alcool şi/sau droguri este concurent cu tulburãrile afective. Treizeci şi douã de procente din toți pacienții cu tulburãri afective sunt de asemenea dependenți de substanțe sau abuzeazã de substanțe de-a lungul vieții lor. Ratele de-a lungul vieții pentru acestã combinaţie este de 60,7 procente pentru tulburarea bipolarã, 27,2 procente pentru tulburarea depresivã majorã şi 31,4 procente pentru tulburarea distimicã. Existã o evidențã din ce în ce mai mare cã abuzul concurent de substanțe înrãutãțeşte prognosticul şi posibilitãţile terapeutice ale tulburãrilor afective.

Comorbiditatea cu alte tipuri de afecțiuni Multe boli pot fi asociate cu tulburãrile afective cuprinzând boli autoimune, afecțiuni neurologice (apoplexie, tulburãri demielinizante, degenerative, traumatice), afecțiuni metabolice, afecțiuni cardiovasculare, endocrinopatii şi cancere specifice (pancreas, plãmâni, rinichi, gastrointestinal, creier). Manifestãrile clinice şi diagnosticul tulburãrii afective care este concurentã cu boala se bazeazã pe aceleaşi criterii ca pentru tulburãrile afective primare pure. 
Chiar dacã tulburãrile afective pot fi asociate cu o extraordinar de largã arie de boli nepsihiatrice, câteva, din cauza importanței lor, ar trebui notate. De exemplu, episoade depresive majore au fost descrise la 25 pânã la 55 procente din pacienții ce au suferit un accident vascular cerebral, în special un accident ce afecteazã lobul frontal anterior stâng. Aceste episoade netratate pot persista mai mult de 12 luni. Tulburarea depresivã majorã a survenit la 8,5 pânã la 60 procente din pacienții cu diabet zaharat, cu prevalența medie de aproximativ 30 procente.

Aproximativ un sfert din pacienții cu cancer experimenteazã o tulburare afectivã semnificativã clinic şi 46 la 75 procente din pacienții cu sindrom de obosealã cronicã au în antecedente o tulburare depresivã majorã. O asociaţie şi mai substanţialã între tulburarea afectivã şi boala medicalã survine la pacienții cu coronaropatie arterialã. Rapoarte aratã cã 18 pânã la 25 procente din pacienţii dupã infarct miocardic suferã de o tulburare depresivã majorã ce trebuie tratatã.

În plus, administrarea cronicã a urmãtoarelor medicamente poate precipita un episod depresiv major: glucocorticoizi, alfametildopa, propranolol, benzodiazepine, derivați de rezerpinã, levodopa, neuroleptice, cimetidinã, indometacin, cicloserinã şi medicamente anticanceroase. Abstinenţa de la stimulenţi ai SNC cum sunt amfetaminele sau de la abuzul de droguri cum este cocaina poate fi de asemenea un factor precipitant.

Este important ca medicul sã-şi dea seama de aceste episoade depresive majore ce survin fie în legãturã cu o boalã, fie cu administrarea unei medicaţii specifice pot fi cel mai important şi deteriorativ aspect al tabloului clinic al pacientului şi necesitã un tratament specific şi imediat (de exemplu, unele studii asupra pacienţilor cu transplant au demonstrat importanța tratãrii depresiei înaintea actului chirurgical pentru a favoriza recuperarea postoperatorie).

Douã strategii pot fi folosite în tratamentul unei tulburãri afective concurente cu o altã boalã. Mai întâi, dacã simptomele sunt din cauza unei tulburãri afective primare "pure", tratamentul trebuie iniţiat într-un regim identic cu cel folosit în afara unei boli concomitente, cu excepția afecțiunilor care necesitã o modificare cum ar fi scãderea dozãrii din cauza unui metabolism hepatic alterat. Când se considerã cã simptomele depresive sunt determinate de o situaţie medicalã, aceasta trebuie tratatã agresiv; în cele din urmã, jumãtate din aceşti pacienţi manifestã remisia simptomelor depresive prin tratamentul eficient al bolii subiacente. Totuşi, deseori este necesar a fi iniţiat tratamentul episodului depresiv major al acestor pacienți pentru a facilita revenirea la starea normalã de sãnãtate. 


\section{Tratament şi profilaxie}

Obiectivele tratamentului farmacologic al afecțiunii bipolare sunt acelea de a stabiliza starea dispoziţionalã şi de a obține remisia episoadelor maniacale şi depresive, iar apoi, dupa finalizarea unei etape acute de tratament, de a menţine remisia şi de a preveni recurenţa episoadelor. Ĩn practicã, aceste obiective sunt atinse prin asocierea unui stabilizator afectiv, cum ar fi litiu, valproat sau/şi lamictal cu un antipsihotic ori un alt agent psihotrop (Hardy et all, 2005).

Ĩn teste randomizate, placebo-controlate, s-a observat cã litiul reduce riscul recurenței cu $41 \%$ şi creşte timpul de solicitare a unei medicații adiționale pentru un episod maniacal sau depresiv.

Ĩn controlul simtomelor maniaco-depresiei sunt utilizate in principal trei clase de substanţe terapeutice: stabilizatori ai dispoziţiei, antidepresive şi antipsihotice. Adiţional pot fi prescrise medicamente pentru insomnie, anxietate sau agitație.

Medicamentele considerate stabilizatori ai stãrii afective trebuie sã îndeplineascã douã condiții: 1) sã ducã la depãşirea unui episod acut de manie sau depresie sau sã previnã apariția unui astfel de episod şi 2) sã nu înrãutãțeascã starea de depresie sau de manie şi sã nu ducã la intensificarea ciclãrii (Kahn et all, 2000). Litiul, valproatul şi carbamazepina şi mai recent lamictalul sunt medicamente ce îndeplinesc aceste condiţii şi au fost considerate principalii stabilizatori ai stãrii afective a pacienților.

Terapia acutã a tulburãrii afective bipolare mixte se realizeaza astfel:

- litiu ĩn doza antimaniacala 1-1,2 mmol/l;

- antipsihotice potente (de exemplu Haloperidol 2x10 mg oral sau i.m.), administrate pe langa litiu, daca e dorit un efect imediat. În Germania, singurul antipsihotic atipic autorizat ĩn tratamentul acut al maniei bipolare este olanzapina;

- carbamazepina sau valproatul - ĩn cazul ĩn care litiul nu acționeaza sau schimbul ĩntre depresie şi manie e foarte rapid (ciclare rapida);

- terapia electroconvulsivanta - ĩn cazuri extreme de terapie refractara.

Profilaxia de recidivã se face ĩn primul rând cu litiu (niveluri plasmatice: 0,5-0,8 $\mathrm{mmol} / \mathrm{l})$. Dacã efectul este prea scãzut, se ridicã doza pânã se ating niveluri plasmatice de $0,8-1,2 \mathrm{mmol} / \mathrm{l}$. În cazul unor rezultate ineficiente, se recurge la carbamazepina, circa 450-1600 mg/zi, cu niveluri plasmatice cuprinse ĩntre 6 şi $12 \mathrm{~g} / \mathrm{ml}$, posibil ĩn combinație cu litiu. Dacã predominã episoadele depresive, se pot adãuga suplimentar antidepresive, iar dacã episoadele maniacale sunt cele predominante, se pot adãuga neuroleptice, ĩntotdeauna ĩn combinație cu litiu sau carbamazepina. Monoterapiile au efect comparabil cu placebo.

\section{CARBONAT DE LITIU - lithium carbonicum}

Acțiune terapeutică Litiul are efecte psihotrope caracteristice la bolnavii cu psihoza maniacală: atenueaza tulburãrile afective (dispoziție expansivã, euforia) şi secundar, starea de agitaţie şi ideile delirante; previne recãderile la bolnavii cu psihoze afective bipolare. 
Indicații: Stãri de excitație ĩn manie sau hipomanie; profilactic, ĩn psihozele ciclice maniaco-depresive; ĩn asociaţie cu un neuroleptic, ĩn accesele de manie violente, cu agitație marcatã, ĩn schizofrenia cu tulburari afective, ĩn psihozele delirante rebele.

Mod de administrare: In accesul de manie, ĩn prima zi 2-3 comprimate sau 500750 mg (fracționat la mese), a 2-a şi a 3-a zi 3-4 comprimate, apoi doze care sã menţina litemia optimala; ĩn stãrile maniacale subacute sau profilactic $1 / 2$ comprimat ĩn prima şi a doua zi (seara), 1 comprimat a 3 -a şi a 4-a zi (câte $1 / 2$ comprimat dimineaţa şi seara), apoi ĩn funcție de litemie. Sângele pentru litemie se recolteaza dimineața, ĩnaintea administrãrii medicamentului; la valori serice de 0,7-1 mEq/1 se menține aceeaşi dozã, valori sub $0,7 \mathrm{mEq} / 1$ necesitã mãrirea dozei, valori mai mari de $1 \mathrm{mEq} / 1$ necesitã scãderea dozei; controlul se face ĩn a 3-a şi a 7-a zi de tratament, apoi o datã la 2 sãptãmani, eventual mai rar.

Reacții adverse: La ĩnceputul tratamentului pot apãrea fenomene toxice majore, trecãtoare: greațã, vomã, diaree, slabiciune, retenție hidrosalina; uneori, ĩn timpul tratamentului cronic, pot surveni: guşa, rareori cu fenomene de hipotiroidism (reversibile la oprirea medicaţiei), diabet insipid nefrogen cu poliurie şi sete, tremor fin şi obosealã muscularã, leucocitozã, erupții psoriaziforme. Innaintea ĩnceperii tratamentului este necesarã investigarea aparatului cardio-vascular, a funcției renale, a funcției tiroidei. Atenție la valori ale litiului seric apropiate de $2 \mathrm{mEq} / 1$ pot apãrea fenomene toxice acute grave.

Contraindicații: Insuficiențã renalã, hipertensiune arterialã; insuficiențã cardiacã, aritmiile cardiace, cardiopatia ischemica, boala Addison, hipotiroidismul netratat contraindicã litiul; nu se administreazã ĩn timpul sarcinii (risc de malformații cardiovasculare sau deprimare centralã, hipotonie, guşa la nou-nascut). În cursul tratamentului nu se administreaza diuretice saluretice (nefrix, furosemid etc.), deoarece deficitul de sodiu determinã reținerea litiului in organism, cu risc toxic sporit; eventualele pierderi de sodiu prin diaree sau sudorație excesive impun suplimentarea sãrii ĩn alimentaţie; litiul nu poate fi folosit la bolnavii obligaţi la dieta hiposodata. Antiinflamatoriile nesteroidiene cresc litemia, acetazolamida micşoreazã efectul litiului, asocierea cu preparate iodate mãreşte riscul afectãrii tiroidei. Tratamentul cu litiu nu se poate face decât dacã existã posibilitatea monitorizãrii concentraţiei serice.

\section{FINLEPSIN- Substanța activã: Carbamazepin.}

Indicații: epilepsii: accese parțiale cu simptomatologie complexã; accese parţiale cu simptomatologie elementarã. Grand mal, in special cu genezã focalã (grand mal din timpul somnului, grand mal difuz), forme mixte de epilepsie. Profilaxia acceselor din sindromul de abstinențã alcoolica ĩn condiții de spitalizare. Nevralgie trigeminalã; nevralgie glosofaringianã. Stãri algice ĩn cadrul neuropatiei diabetice. Accese neepileptice din scleroza multiplã, cum ar fi: nevralgia trigeminalã, crize tonice, disartrii paroxistice, ataxii sau parestezii paroxistice, ca şi accese dureroase. Psihoze, ĩn special afecțiuni 
maniaco-depresive, depresii hipocondre şi anxioase cu agitatie, ca şi stãri de excitaţie catatonicã.

Contraindicații: Antecedente de leziuni ale maduvei osoase. Afecțiuni ale sistemului de conducere cardiac (bloc AV). Hipersensibilitate cunoscutã la carbamazepin, antidepresive triciclice sau litiu. $\mathrm{Nu}$ se recomandã administrarea concomitent sau cel putin 14 zile dupa administrarea de inhibitori MAO.

Efecte secundare: Mai frecvente ĩn cazul tratamentelor asociate decât ĩn cazul monoterapiei. În funcție de dozã şi ĩn special la ĩnceputul tratamentului, pot apãrea adeseori: sedare, somnolențã, amețeli, ataxie cerebeloasã, ocazional cefalee; la pacienții vârstnici se pot produce: dezorientare, nelinişte, mişcãri involuntare, flappor, tremor, tresãriri musculare, nistagmus, iar ĩn cazuri izolate s-au observat tulburãri de vorbire, parestezii, astenie muscularã, nevrite periferice, pareze ale membrelor inferioare; izolat sau consemnat halucinații, stãri depresive, dificultãți de gândire, scaderea iniţiativei, comportament agresiv, posibilitatea activarii de psihoze latente; ĩn literaturã exista date izolate asupra unei forme alergice de meningitã aseptica indusa de carbamazepin, iar la pacienții vârstnici sau cu leziuni cerebrale s-au descris tulburãri dischinetice.

La pacienții cu glaucom trebuie controlatã periodic tensiunea intraoculara. S-a raportat, de asemenea, opacifierea cristalinului. Izolat, s-au semnalat artralgii, mialgii, contracturi musculare (fenomene ce dispar la ĩntreruperea tratamentului).

\section{VALPROAT (DEPAKINE®, pulvere liofilizată) - natrium valproicum}

Proprietăți: Antiepileptic. Proprietățile sale anticonvulsivante se exercită asupra unor tipuri foarte variate de crize convulsive la animal şi epileptice la om.

Studiile experimentale şi clinice asupra valproatului de sodiu sugerează două tipuri de acțiune anticonvulsivantă: direct, datorat concentrației valproatului de sodiu în plasmă şi în creier şi indirect, fie determinat de metaboliți ai valproatului de sodiu prezenți în creier sau legat de modificări ale neurotransmițătorilor, fie este legat de efecte membranare directe. În general, este admisă ipoteza acidului gama-aminobutiric (GABA), a cărui concentraţie creşte după administrarea valproatului. Valproatul diminuează durata fazelor intermediare ale somnului, cu o creştere concomitentă a somnului lent.

Farmacocinetică: Din diferite studii farmacocinetice efectuate cu valproat, reies următoarele date: după administrarea orală sau i.v. a valproatului, biodisponibilitățile sunt comparabile şi aproape 100\%; volumul de distribuție este limitat la sânge şi lichide extracelulare cu schimb rapid. Valproatul difuzează în L.C.R. şi în creier; eliminarea este rapidă (timp de înjumătătire 15 - 17 ore), ceea ce necesită, deci, o administrare regulată; eficacitatea terapeutică necesită o concentrație minimă de $40-50 \mathrm{mg} / 1$, cu o paletă largă, cuprinsă între 40 şi $100 \mathrm{mg} / 1$. Nivelurile care se menţin peste $200 \mathrm{mg} / \mathrm{l}$ necesită o reducere a posologiei; pe cale orală, concentrația plasmatică de echilibru este atinsă rapid (3 - 4 zile); cu forma injectabilă, ea poate fi atinsă în câteva minute şi menţinută prin perfuzie venoasă; fixarea proteică a valproatului este foarte importantă. Ea este dependentă de doză şi saturabilă; eliminarea valproatului se face mai ales urinar, după metabolizare prin 
glucuronoconjugare şi beta-oxidare; molecula valproatului este dializabilă, dar hemodializa atinge doar fracția liberă de acid valproic sanguin (în jur de 10\%); contrar majorităţii celorlalte antiepileptice, valproatul nu accelerează propria sa degradare, nici cele ale altor substanțe, cum ar fi estroprogestativele. Această proprietate traduce absența efectului inductor al enzimelor ce implică citocromul P 450.

Indicații terapeutice: Tratamentul epilepsiei, pe o perioadă mai scurtă de 3 zile, în locul administării orale, dacă aceasta este temporar inutilizabilă.

Contraindicații: Hepatită acută. Hepatită cronică. Antecedent familial de hepatită severă, în special medicamentoasă. Hipersensibilitate la valproat.

Sarcină şi alăptare: Sarcină: Risc legat de epilepsie şi de antiepileptice: Referitor la antiepileptice în general, s-a demonstrat că în descendența femeilor epileptice tratate, nivelul global al malformațiilor este de $2-3$ ori superior celui (aproximativ 3\%) existent la populația generală. Malformațiile cel mai frecvent întâlnite sunt fante labiale şi malformații cardiovasculare.

Interacțiuni medicamentoase: Asocieri necesitând precauții la utilizare: neuroleptice şi antidepresive: valproatul poate potența acțiunea neurolepticelor şi a antidepresivelor, ca şi efectele lor secundare după administrarea unor doze mari.

\section{LAMICTAL - lamotriginum}

Indicații: Adulţi: Lamictal este un medicament antiepileptic (AED) indicat ca terapie asociată sau monoterapie în tratamentul crizelor parţiale şi generalizate, inclusiv tratamentul crizelor tonico-clonice şi al crizelor asociate cu sindromul Lennox-Gastaut.

Copii: Lamictal este indicat ca terapie asociată în tratamentul epilepsiei, pentru crize parțiale şi generalizate, inclusiv crizele tonico-clonice şi cele asociate sindromului Lennox-Gastaut.

Dozele recomandate în monoterapie: Adulți şi copii peste 12 ani: Doza iniţială de Lamictal în monoterapie este de $25 \mathrm{mg}$ o dată pe zi, timp de două săptămâni, urmată de $50 \mathrm{mg}$ o dată pe zi, timp de două săptămâni. După aceea, doza poate fi crescută la maxim 50-100 mg alte 1-2 săptămâni până când răspunsul optim este obținut. Doza de întreținere obişnuită pentru obținerea unui răspuns terapeutic optim este de 100-200 mg/zi administrată o dată pe zi sau în două doze divizate.

Dozele recomandate în terapia asociată: Adulți şi copii (în vîrstă de peste 12 ani): La pacienții tratați cu valproat cu/fără alt medicament anti-epileptic (AED), doza inițială de Lamictal este de 25 mg (o zi da, următoarea nu) timp de două săptămâni, urmată de 25 mg Lamictal, o dată pe zi, timp de 2 săptămâni. După aceea, doza poate fi crescută cu maxim 25-50 mg la fiecare 1-2 săptămâni până când răspunsul optim este obținut. Doza de întreținere, pentru a obține un răspuns terapeutic optim este de 100-200 mg/zi într-o singură doză sau în două doze.

Contraindicații: Lamictal este contraindicat la pacienții cu sensibilitate cunoscută la lamotrigină. 
Precauții speciale pentru utilizare: $A u$ fost raportate unele reacții adverse cutanate, care au apărut în general în primele 8 săptămâni după inițierea tratamentului cu Lamictal. Majoritatea rash-urilor sunt uşoare şi autolimitate, totuşi s-au raportat unele cazuri de rash cutanat serios, cu potențial amenințător asupra vieții, ca de exemplu sindromul Stevens Johnson (SJS) şi necroliza epidermică toxică (TEN).

Rash-ul a fost de asemenea raportat ca parte a sindromului de hipersensibilitate asociat cu un model variabil de simptome ce includ febra, limfadenopatia, edemul facial şi anormalităţi ale sângelui şi ficatului.

Lamictal este un inhibitor slab al dihidrofolatreductazei, de aceea există posibilitatea interferenței cu metabolismul folaților în timpul terapiei pe termen lung. Totuşi, în timpul tratamentului uman prelungit, lamotrigina nu induce modificări semnificative ale concentrației hemoglobinei, volumului corpuscular mediu sau ale concentrației folaților din ser sau din eritrocite timp de 1 an sau ale concentrației folaților din eritrocite timp de 5 ani.

\section{Tratamentul fazelor depresive}

Depresia se caracterizează prin dispoziţie depresivă, pierderea intereselor şi a bucuriilor şi o reducere a energiei ce duce la o fatigabilitate crescândă şi la o activitate diminuată. Antidepresivele trateazã simptomele depresiei. Ĩn cazul maniaco-depresiei, antidepresivele trebuiesc asociate unui stabilizator al stãrii afective a pacientului. Fãrã utilizarea acestuia, pacientul poate sã ajungã într-un episod maniacal. Mai multe tipuri de antidepresive sunt disponibile, cu mecanisme biochimice de acțiune diferite, dar şi cu profile diferite ale efectelor secundare. Cele mai multe cercetãri privind antidepresivele sau desfãşurat la pacienții cu depresie unipolarã, care nu au prezentat un episod maniacal.

Puținele cercetãri privind utilizarea antidepresivelor în maniaco-depresie au indicat cã primele trei alegeri pentru tratament se pot considera:

1. Bupropion (Wellbutrin) este un tratament de prima linie in depresie;

2. Inhibitori selectivi ai recaptarii serotoninei: Fluoxetina (Prozac), Fluvoxamina (Fevarin), Sertralina (Zoloft), Paroxetina (Seroxat), Citalopram (Cipramil), Escitalopram (Cipralex) sunt cele mai utilizate in prezent, cel putin la fel de eficace ca si antidepresivele triciclice, dar cu mai putine efecte adverse;

3.Venlafaxina (Efectin) este eficienta in tratamentul depresiei severe cu elemente melancolice si are debut rapid al actiunii.

Ĩn cazul în care cele trei tipuri de medicamente nu funcţioneazã, sau efectele secundare sunt predominante, urmãtoarele alegeri ar putea fi:

- Mirtazapina (Remeron) este eficienta in depresia severa;

- Nefazodone (Serzone);

- Inhibitorii de monoaminoxidaza (IMAO): phenelzine (Nardil), tranylcypromine (PaARNte) - sunt eficienti dar rar utilizati de psihiatri din cauza precautiilor dietetice (pot determina hipertensiune arteriala) si interactiunilor medicamentoase daunatoare 
- Antidepresive triciclice: Imipramina, Amitriptilina, Doxepina au ca indicatie principala depresia majora, iar Clomipramina este foarte eficace in tulburarea obsesivcompulsiva. Superioritatea acestor antidepresive fata de antidepresivele noi se manifesta in cazurile de episoade depresive melancolice. Antidepresivele triciclice sunt mai putin recomandate din cauza efectelor adverse (sedare, hipotensiune ortostatica, tulburari urinare, constipatie, etc.)

$\mathrm{Cu}$ toate ca indicatia principala a antidepresivelor este tratamentul depresiei, aceste substante si-au mai dovedit utilitatea si in: faza depresiva a tulburarii bipolare, tulburarea obsesiv compulsiva, tulburarea de panica, tulburarea de stres posttraumatica, tulburarile de alimentatie, fobia sociala, enurezis, dureri cronice.

Medicația antipsihoticã este destinatã controlului simptomelor psihotice de tipul halucinațiilor sau iluziilor, care uneori apar în episoadele manicale sau depresive.

Antipsihoticele pot fi utilizate în cazul afecțiunii bipolare, chiar daca simptomele psihotice nu sunt prezente, fie ca sedative, mai ales în stadiile incipiente ale tratamentului, pentru combaterea insomniei, a anxietãţii sau a agitaţiei, fie pentru întãrirea efectului stbilizatorilor dispoziționali.

Antipsihoticele se impart in:

- antipsihotice conventionale (neuroleptice) care determina reducerea tulburarilor psihotice, predominant a simptomelor pozitive (halucinatii, delir, perturbarea gandirii si agitatia) dar au ca dezavantaj producerea sindromului extrapiramidal si a unor manifestari neuro-vegetative.

- antipsihotice atipice care determina ameliorarea simptomatologiei pozitive, negative (retragere sociala, aplatizare afectiva, anhedonie, catatonie), precum si imbunatatirea afectarii cognitive (distorsiuni perceptuale, deficite de memorie si atentie); acestea dau foarte rar fenomene extrapiramidale sau diskinezii tardive si de aceea sunt de preferat. Au ca dezavantaj tendinta de modificare a formulei sangvine si perturbarile metabolice.

Exemple de antipsihotice:

1. Antipsihotice conventionale (neuroleptice): Haloperidol, Clorpromazina, etc.

2. Antipsihotice atipice: Risperidona (Rispolept), Olanzapina (Zyprexa), Quetiapina

(Seroquel), Ziprasidona (Zeldox), Clozapina (Leponex), Sertindole, Amisulprid (Solian), Aripiprazol (Abilify), etc.

\section{Quetiapina}

Quetiapina este un medicament antipsihotic care se regăseşte în tratamentul schizofreniei şi al episoadelor maniacale asociate tulburării bipolare de tip I.

FDA a luat în considerare noi date despre eficacitatea Quetiapinei în tratamentul episoadelor maniacale la pacienții cu tulburări bipolare de tip I.

Studii clinice au demonstrat că, după 12 săptămâni, circa două treimi dintre pacienții care au luat Quetiapină au înregistrat o remisie a maladiei. 
Un total de 599 de pacienți care aveau episoade maniacale au fost desemnați să primească Quetiapină sau placebo. Scopul final era reprezentat de schimbarea punctajului YMRS (Young Mania Rate Scales) la 21 de zile de tratament.

În cea de-a 12-a săptămână, 65,4\% dintre pacienții trataţi cu Quetiapină au înregistrat o remisie a bolii (definită conform scalei YMRS ca egală sau mai mică de 12), față de 35,9\% dintre subiecții grupului "placebo".

Antipsihoticele atipice, printre care şi Quetiapina, pot provoca: diskinezie tardivă, convulsii, hipotensiune ortostatică. Au fost raportate cazuri de diabet zaharat şi hiperglicemie la uzul îndelungat de antipsihotice atipice. (FDA - Food and Drug Administration).

\section{RISPOLEPT}

Farmacodinamica: Risperidone este un antagonist monoaminergic selectiv cu proprietati unice. Are o afinitate ridicatã pentru receptorii serotoninergici 5-HT2 şi dopaminergici D2. Risperidone se leaga de asemenea de receptorii alfa1-adrenergici şi, cu o afinitate mai scazutã, de receptorii H1-histaminergici şi alfa2-adrenergici. Risperidone nu are afinitate pentru receptorii colinergici.

Farmacocinetica: Risperidone este complet absorbit dupã administrarea oralã, atingând un vârf plasmatic ĩn 1 - 2 ore. Risperidone este parțial metabolizat ĩn 9-hidroxi risperidone, care are o activitate farmacologica similara risperidonei. Risperidone ĩmpreuna cu 9-hidroxi risperidone formeazã fracția antipsihoticã activã. Risperidone este metabolizat şi prin N-dezalchilare. Dupã administrarea oralã la pacienţii psihotici, risperidone are un timp de injumãtãţire de aprox. 3 ore. Timpul de injumãtãțire a 9hidroxirisperidonei şi al fracţiei antipsihotice active este de 24 de ore. Nivelul plasmatic de echilibru a risperidonei este atins, la majoritatea pacientilor, dupã o zi, iar cea a 9hidroxirisperidonei dupã 4-5 zile de administrare.

Indicații: Rispolept este indicat pentru tratamentul schizofreniei acute şi cronice, inclusiv al primului episod psihotic, precum şi al altor stãri psihotice, ĩn care simptomele pozitive (halucinații, deliruri, tulburãri de gândire, ostilitate, suspiciune) şi/sau simptomele negative (aplatizare afectivã, ĩnstrainare socialã şi retragere emoționala, vocabular redus) sunt predominante. Rispolept atenueazã de asemenea simptomele afective (depresie, vinovãţie, anxietate) asociate schizofreniei. Rispolept este de asemenea indicat şi ca terapie pe termen lung pentru prevenirea exacerbãrilor acute la pacienţii cu schizofrenie cronicã.

Avertismente şi precautii: Datoritã acțiunii alfa-blocante a Rispoleptului, poate apãrea hipotensiune ortostaticã, ĩn special ĩn perioada iniţialã de titrare a dozei. Rispolept trebuie folosit cu grija la pacientii cu boli cardiovasculare (insuficiențã cardiacã, tulburãri de conducere, infarct de miocard, deshidratare, hipovolemie, sau boli cerebrovasculare). Daca apare hipotensiune, poate fi considerata necesara reducerea dozei.

Medicamentele cu proprietãți antagonice asupra receptorilor dopaminergici au fost asociate cu inducerea dischineziei tardive caracterizate prin mişcãri ritmice involuntare, 
predominant ale limbii şi/sau feței. S-a raportat cã apariţia simptomelor extrapiramidale este un factor de risc pentru apariția dischineziei tardive.

Administrarea de Rispolept trebuie facutã cu precauție la pacienții cu boala Parkinson, deoarece, teoretic, ar putea duce la agravarea bolii.

Interacțiuni: Riscul folosirii Rispoleptului ĩn combinaţie cu alte medicamente nu a fost evaluat sistemic. Carbamazepina scade nivelele plasmatice ale fracției antipsihotice active ale Rispoleptului.

ZYPREXA - olanzapinum

Indicații terapeutice: Olanzapina este indicată pentru tratamentul schizofreniei. Olanzapina este efectivă în menținerea ameliorării clinice în cursul tratamentului de întreținere la pacienții care au manifestat răspuns clinic la tratamentul inițial.

Avertismente şi precauții: Deşi olanzapina manifestă activitate anticolinergică in vitro, experiența acumulată în cursul trialurilor clinice a evidențiat o incidență redusă a evenimentelor adverse de acest tip. Totuşi, dat fiind că experiența clinică privind olanzapina la pacienții cu boli asociate este limitată, se recomandă precauție în prescrierea la bolnavii cu hipertrofie de prostată sau ileus paralitic, ori cu alte condiții înrudite. Lactoza: Tabletele de olanzapină conțin lactoză. Ocazional, în special în perioada precoce a tratamentului, au fost constatate ascensiuni tranzitorii, asimptomatice, ale transaminazelor hepatice, ALAT, ASAT.

Ca şi în cazul altor medicamente neuroleptice, este necesară prudență la bolnavii cu scăderi ale leucocitelor şi/sau neutrofilelor, indiferent de cauza acestora, la bolnavii cu istoric de depresie/ toxicitate indusă de medicamente la nivelul măduvei osoase, la pacienţii cu depresie a măduvei osoase cauzată de boli concomitente, radioterapie sau chimioterapie şi la bolnavii cu condiții hipereozinofilice sau cu afecțiuni mieloproliferative.

Sindromul neuroleptic malign (NMS): În trialurile clinice nu au existat cazuri raportate de NMS la bolnavii care au primit olanzapină. NMS, care este un complex simptomatologic cu potenţial letal, a fost raportat în asociere cu alte medicamente antipsihotice. Manifestările clinice ale NMS constau din hiperpirexie, rigiditate musculară, stare mintală alterată şi dovezi de instabilitate autonomă. Olanzapina trebuie utilizată cu prudență la pacienții cu istoric de convulsii sau care au condiții asociate cu convulsiile.

Pentru că manifestă antagonism al dopaminei in vitro, olanzapina poate antagoniza efectele agoniştilor direcți sau indirecți ai dopaminei. Hipotensiunea posturală a fost observată infrecvent în trialurile clinice ale olanzapinei la vârstnici. Ca şi în cazul altor antipsihotice, se recomandă măsurarea periodică a tensiunii arteriale la pacienții în vârstă de peste 65 de ani. 


\section{Efectele litiului asupra morfologiei culturilor de celule gliale}

Efectele litiului asupra sistemului nervos au fost studiate intensiv datorită utilizării acestuia în tratamentul psihozei maniaco-depresive (Gilles şi Bannigan, 1997; Lenox şi Hahn, 2000).

Tratamentul cu clorură de litiu a început din ziua a 6-a de cultivare a celulelor gliale, după faza de lag, moment ce corespunde startului multiplicărilor celulare, a formării insulelor celulare şi a diferențierii celulare pronunțate.

Tratamentul cu clorură de litiu presupune utilizarea unui mediu de cultivare preparat împreună cu o cantitate de clorură de litiu ce corespunde unei concentraţii de 1 şi respectiv $2 \mathrm{mM}$ litiu. Conform protocolului de lucru utilizat, prepararea mediului cu clorură de litiu presupune obținerea unei soluții stoc de clorură de litiu de $20 \mathrm{mM}$, în mediu DMEM, din care se utilizează volume specifice pentru obținerea concentrațiilor dorite.

Schimbarea mediului şi aplicarea tratamentului cu litiu, la concentrația de 1 şi respectiv $2 \mathrm{mM}$, are loc la o frecvență de trei zile de cultivare.

Concentraţia de $1 \mathrm{mM}$ litiu corespunde nivelului seric terapeutic al litiului, atins în cadrul tratamentului maniaco-depresiei, nivel ce trebuie atent monitorizat pentru a nu fi depăşit.

Concentrația de $2 \mathrm{mM}$ litiu reprezintă o doză toxică pentru organism, fapt demonstrat de majoritatea studiile desfăşurate până în prezent în diferite centre de cercetare care au vizat efectele litiului.

Efectele biologice ale litiului pot fi împãrțite în: efecte pe termen scurt (manifestate la scurt timp dupã aplicare şi probabil mediate prin complexul celular disponibil) şi efecte pe termen lung (presupuse a se baza pe schimbãrile selective în expresia genelor şi care apar dupã o perioadã de întârziere de la câteva zile la sãptãmâni). Multe dintre efectele litiului pe termen scurt par a fi specifice celulelor sau țesuturilor. Exemple de efecte stimulatorii pe termen scurt includ secreția de corticotropinã indusã de litiu a celulelor pituitare anterioare de şobolan şi eliberarea masivã de glutamat la porţiuni din creier tratate cu litiu. Efectele inhibitorii ale tratamentului pe termen scurt cu litiu sunt dovedite de secreția de aldosteron indusã de angiotensina II a celulelor glomerulare adrenale şi coeficientul de relaxare ce urmeazã inducerii colinergice a contracţiei muşchiului neted.

Printre schimbãrile fenotipice pe termen lung se pot menționa alterãri induse de litiu asupra ritmului circadian şi desigur schimbãri de comportament la pacienţii cu afecțiuni bipolare apãrute dupã 2-3 zile sau câteva sãptãmâni.

Tratamentul cronic cu litiu la şobolanii de laborator duce la un deficit persistent de execuție la unele teste de comportament (evitarea activã şi vizualã a labirintului), luând în considerare cã deficitul la o sarcinã cu memorie spațialã este trecãtor. 


\section{LITIU $1 \mathrm{mM}$ Ziua 7}
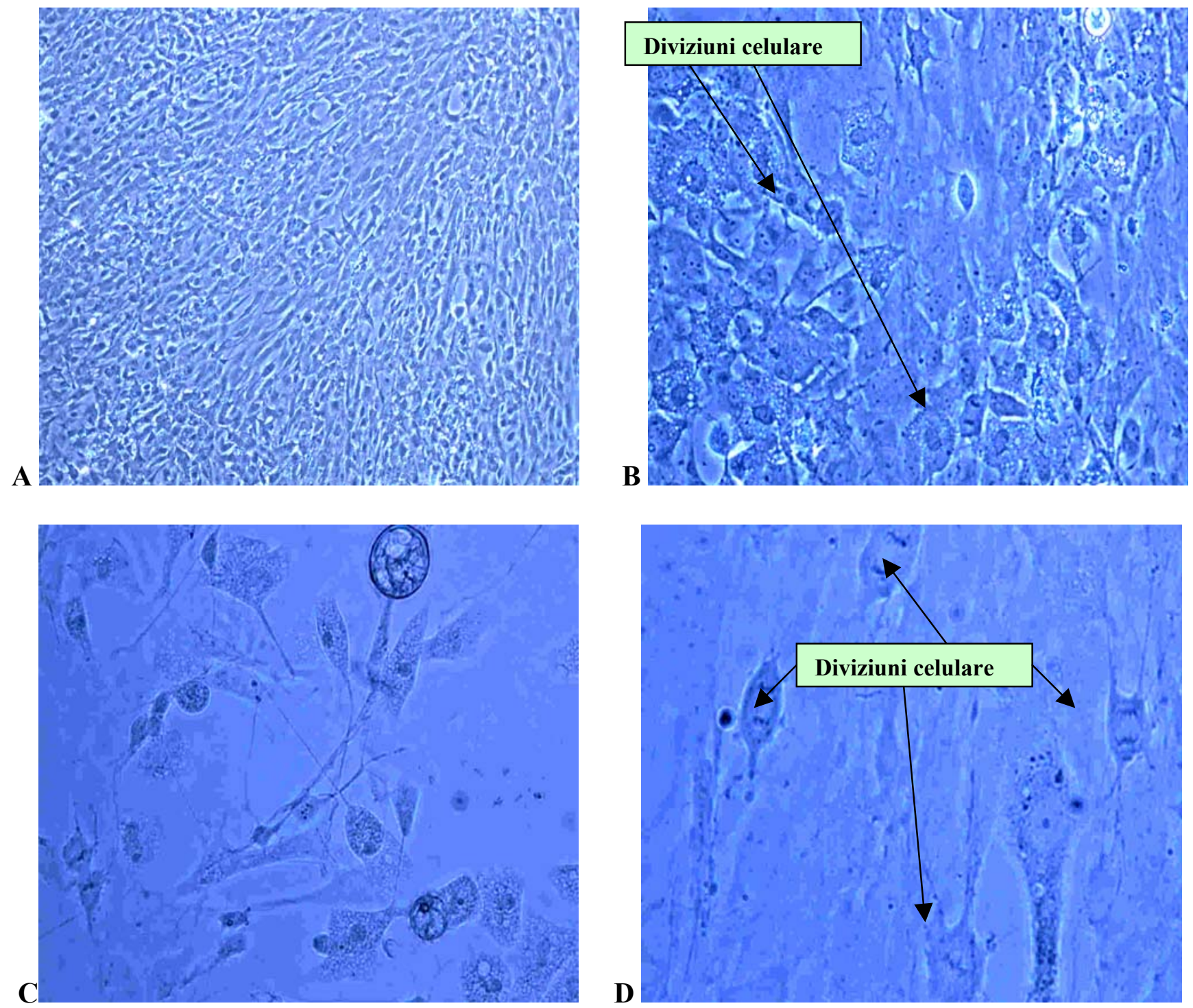

Fig. 16 Aspect de microscopie optică al culturii de 7 zile tratată cu LiCl 1mM (A- mărire x10 - insula de celule, B- mărire x30, C- mărire x40, D- mărire x40)

Tratamentul cu LiCl 1mM determină, după 24 de ore, apariția unor vacuole celulare, uşoare măriri ale volumui celular, creşterea proceselor celulare şi o creştere semnificativã a ratei de diviziune (fig. $16 \mathrm{~B}$ şi D), fapt demonstrat de dimensiunea insulelor celulare (fig. $16 \mathrm{~A}$ ), în comparaţie cu culturile martor de celule gliale.

Multiplicările celulare se produc şi în afara insulelor celulare, fapt ce nu a fost observat la culturile martor de celule gliale.

Celulele gliale din culturã prezintã morfologii variate (fig. 16 B şi C), celulele aparținând astrocitelor, oligodendrocitelor sau microgliilor. 


\section{LITIU $1 \mathrm{mM}$ ziua 9}
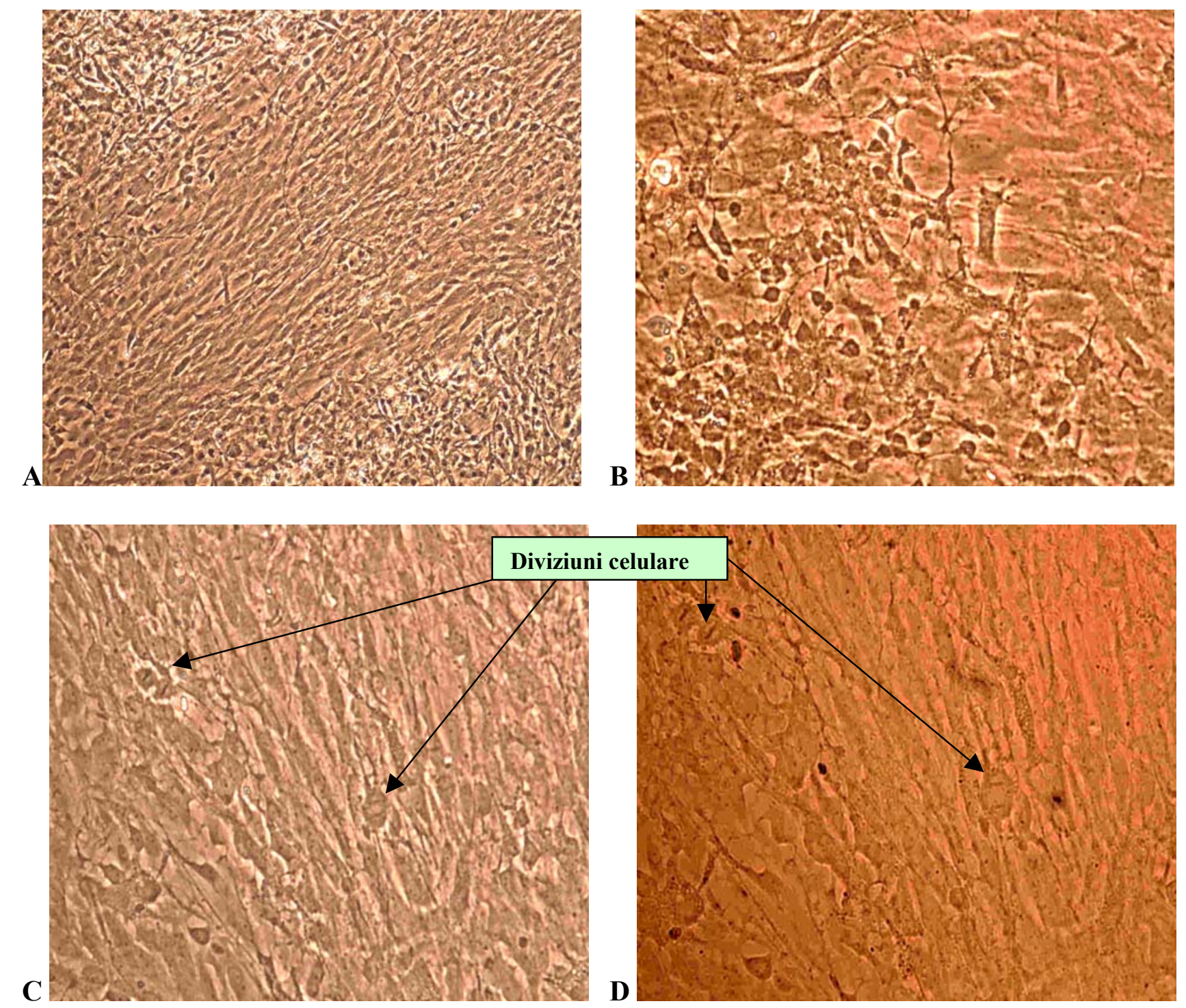

Fig. 17 Aspect de microscopie optică al culturii de 9 zile tratată cu LiCl 1mM

(A- mărire x10 - insula de celule, B- mărire x20, C- mărire x30, D- mărire x40)

În ziua a 9-a, creșterea diametrului insulelor celulare indică un nivel crescut al diviziunilor celulare (fig. 17 C-D), fiind de altfel observate numeroase celule surprinse în diferite etape ale ciclului mitotic. Culturile tratate cu $1 \mathrm{mM} \mathrm{LiCl}$ prezintă puţine celule cu caractere patologice, reprezentate de creşteri exagerate în volum, anucleație sau polinucleație, resorbții celulare, moarte celulară programată, vacuolizări. Situația generalã este foarte asemãnãtoare cu cea din cazul martor, ceea ce indicã faptul cã Li $1 \mathrm{mM}$ nu genereazã dezechilibre ale creşterii şi diviziunii celulare (fig. 17 A-D). Apar de asemenea orientãri în spaţiu ale celulelor gliale şi ale prelungirilor acestora (Fig. 17 A şi C), fiind mimate aspecte tisulare.Se poate analiza variabilitatea tipurilor de celule gliale prezente în culturã şi care conferã caracterul heterogen al acesteia. 


\section{LITIU $1 \mathrm{mM}$ ziua 11}
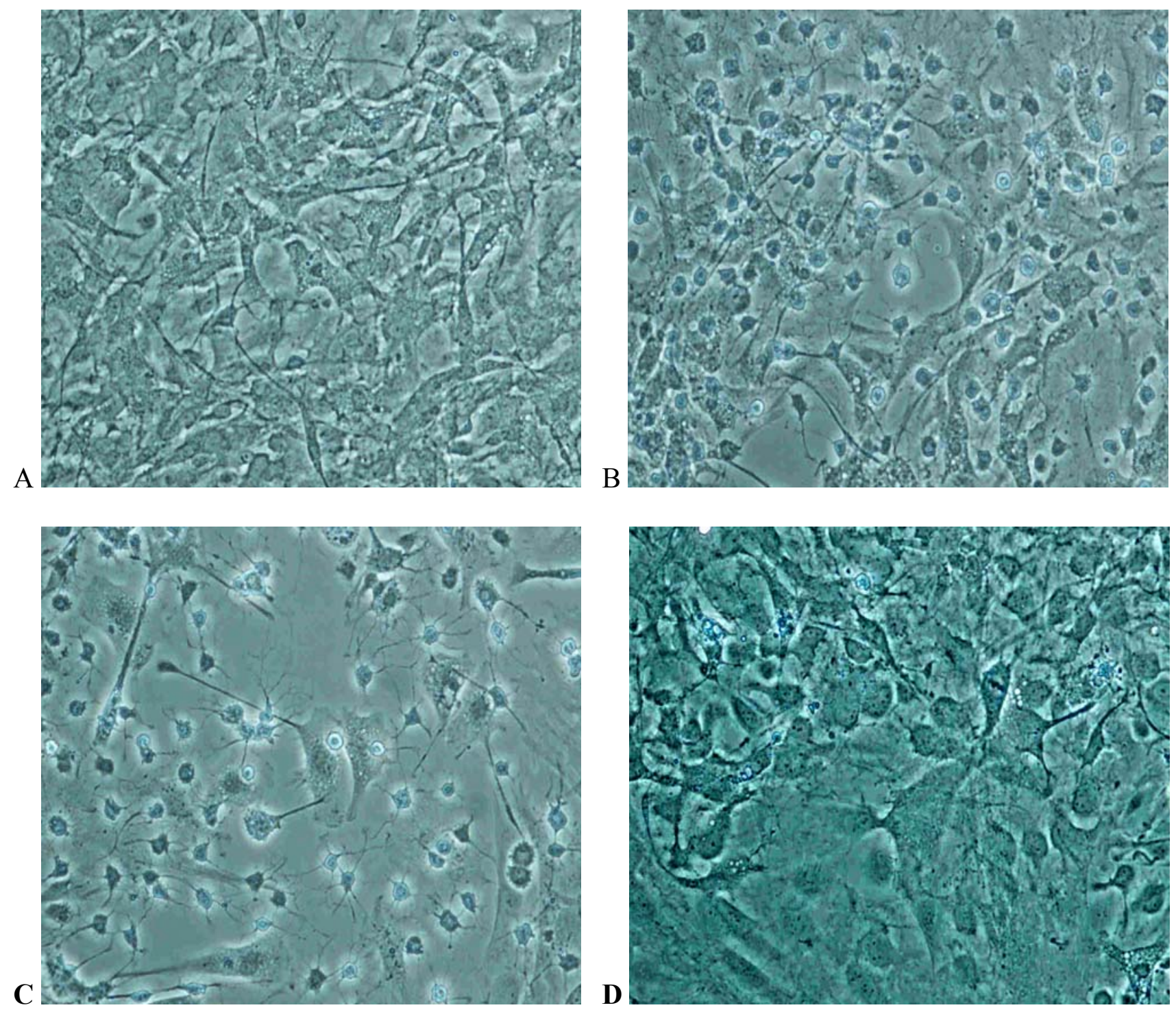

Fig. 18 Aspect de microscopie optică al culturii de 11 zile tratată cu LiCl 1mM (A- mărire x30, B- mărire x30, C- mărire x40, D- mărire x40)

Cultura de celulele gliale de 11 zile tratate cu $1 \mathrm{mM} \mathrm{LiCl}$ prezintă un proces de suprastructurare a arhitecturii culturale, fiind mimate structuri tisulare complexe, de tipul centrelor nervoase (fig. 18 A-D).

Apar cu o frecvență crescută resorbții celulare (fig. 18 B) şi vacuolizãri, dar aspectul general al culturii nu diferã foarte mult de cel observat în cazul martor.

Multiplicările celulare pot fi observate încă prin observații microscopice, fiind surprinse celule gliale în diferite etape mitotice (fig. 18 D). Se observă, ca şi la martor, existența unor zone ale culturii în care predominã anumite tipuri de celule gliale, de exemplu astrocite de tip I - fig. $18 \mathrm{C}$, sau astrocite de tip II - fig. 18 A. 


\section{LITIU $1 \mathrm{mM}$ Ziua 13}
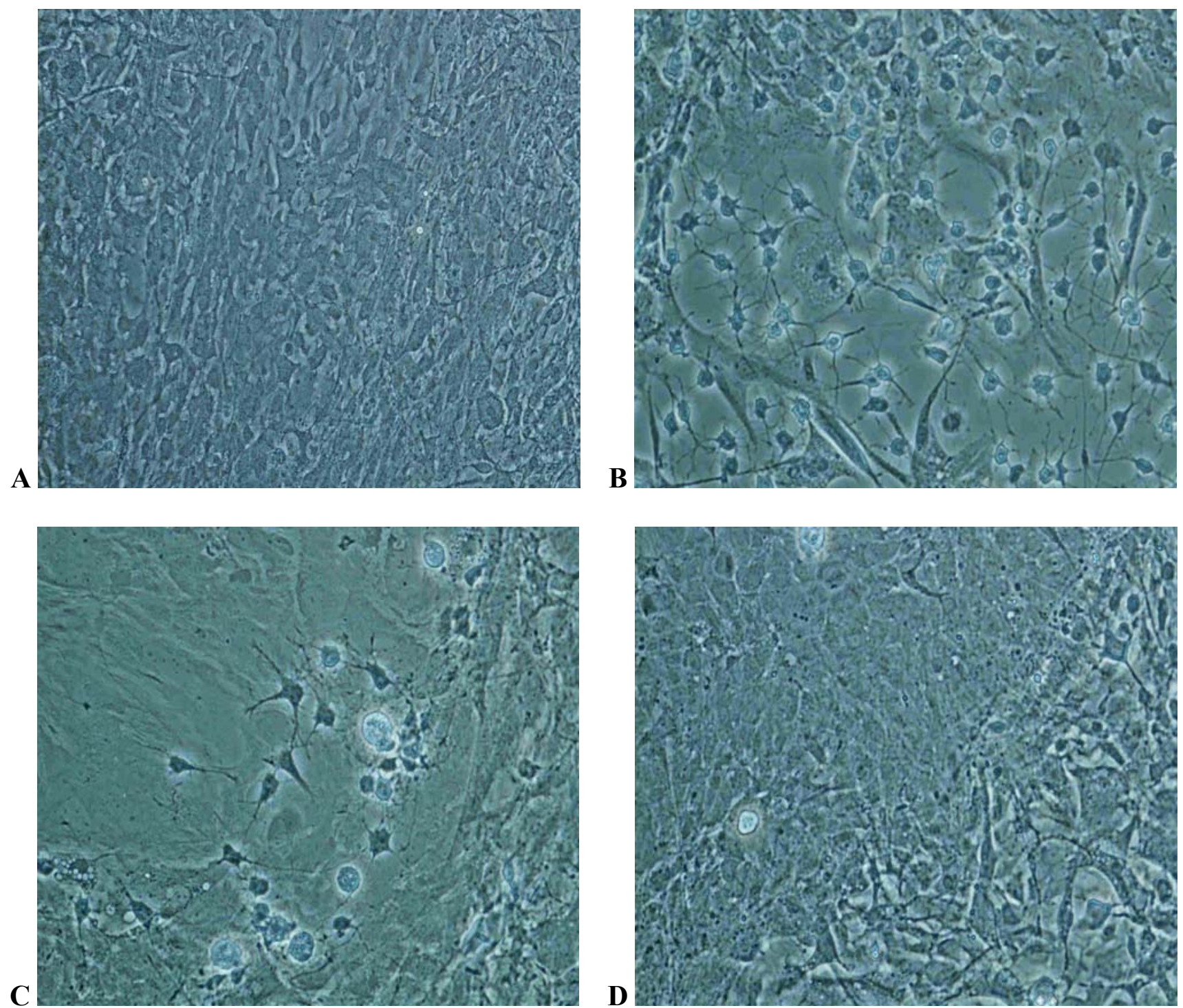

Fig. 19 Aspect de microscopie optică al culturii de 13 zile tratată cu LiCl 1mM (A- mărire x30, B- mărire x30, C- mărire x30, D- mărire x30)

În ziua a 13-a, cultura de celulele gliale tratată cu $1 \mathrm{mM} \mathrm{LiCl}$ prezintă un avansat nivel de maturare, fiind mimate structuri tisulare complexe, de tipul centrilor nervoşi prezenți în structura SNC (fig. 19 C şi D).

Heterogenitatea culturii se poate descrie prin variabilitatea mare a tipurilor de celule gliale prezente în cadrul acesteia (fig. 19 A-D), dar şi prin gradul diferit de maturare al celulelor gliale.

Apar la un nivel de echilibru, resorbții (fig. 19 B) şi multiplicări celulare în funcție de nevoile de plasticitate structuralã a culturii de celule gliale ajunsã la aceastã etapã. 


\section{LITIU 1mM Ziua 15}
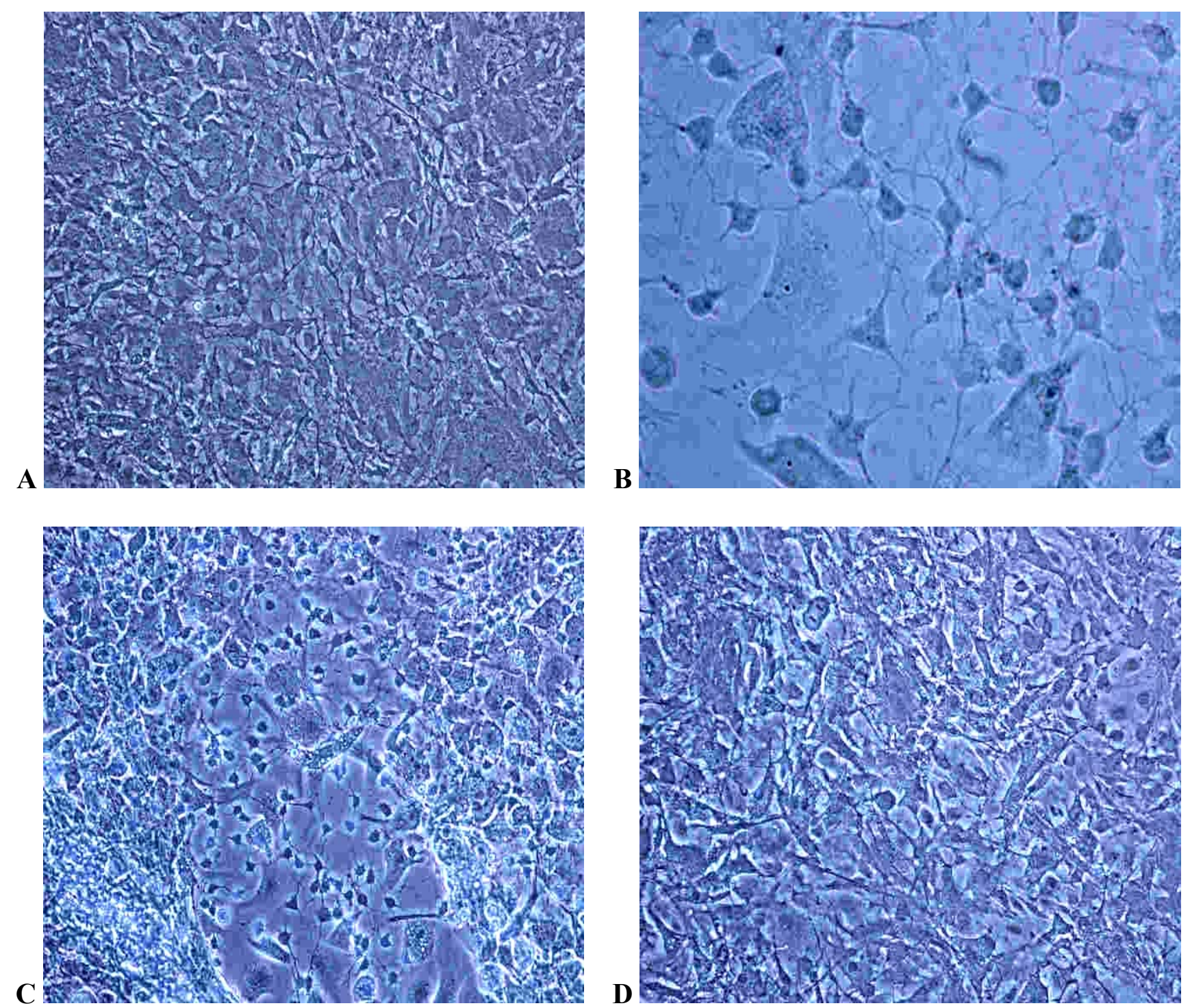

Fig. 20 Aspect de microscopie optică al culturii de 15 zile tratată cu LiCl 1mM (A- mărire x20, B- mărire x40, C- mărire x20, D- mărire x20)

În ziua a 15 -a, cultura de celulele gliale tratată cu $1 \mathrm{mM} \mathrm{LiCl}$ prezintă un aspect asemãnãtor cu cel descris în ziua precedentã, fiind menţinut gradul de confluențã al culturii (fig. 20 A-D). Sunt mimate structuri tisulare complexe. Apar cu o frecvență crescută resorbții celulare. Multiplicările celulare pot fi observate încă prin observații microscopice. Se observă procese morfopatologice. Aspectul este asemãnãtor cu al culturii martor din aceeaşi zi. La acest moment are loc stoparea creşterii, prelevarea mediului de culturã pentru analize biochimice şi pregãtirea culturii pentru obținerea omogenatului proteic total ce va reprezenta proba analizelor electroforetice şi pentru Western Blotting. 


\section{LITIU 2 mM ziua 7}
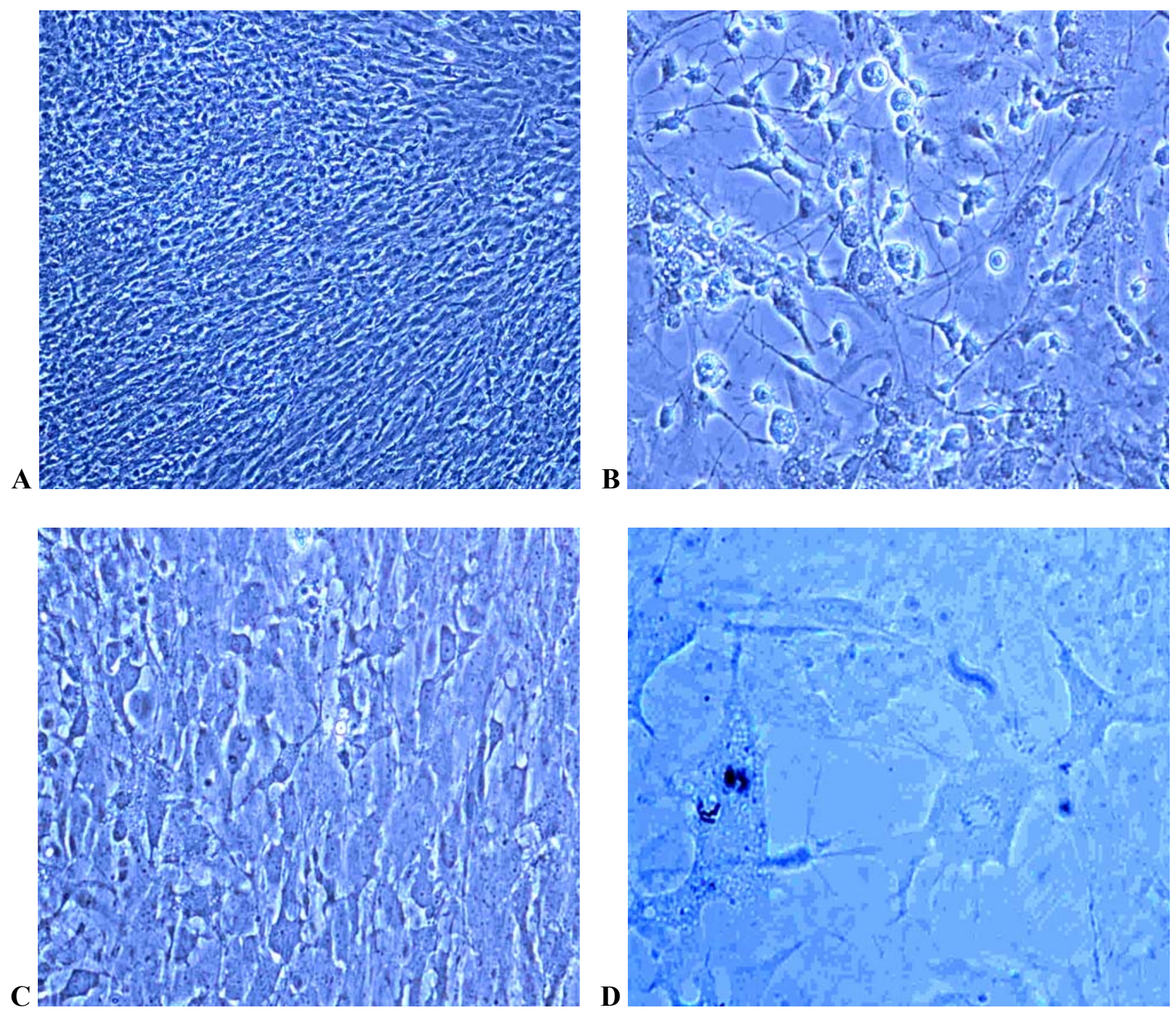

Fig. 21 Aspect de microscopie optică al culturii de 7 zile tratată cu LiCl $2 \mathrm{mM}$ (A- mărire x10, B- mărire x10, C- mărire x10, D- mărire x10)

Tratamentul cu LiCl $2 \mathrm{mM}$ determină, după 24 de ore, intensificarea nivelului diviziunilor celulare, fapt demonstrat de dimensiunea insulelor celulare şi de numeroasele celule surprinse în diferite etape ale fazei mitotice a ciclului celular (fig. 21 C şi D). Diviziunile celulare au loc şi în spațiul existent între insulele celulare. Analiza microscopicã a culturii relevã gradul ridicat al heterogenitãții sale, fiind prezente tipuri diferite de celule gliale: astrocite, oligodendrocite, microglii (fig. 21 A - D), aflate în diferite etape de diferențiere şi maturare. Aspectul general al culturii nu diferã de aspectul culturii martor. 


\section{LITIU 2 mM Ziua 9}
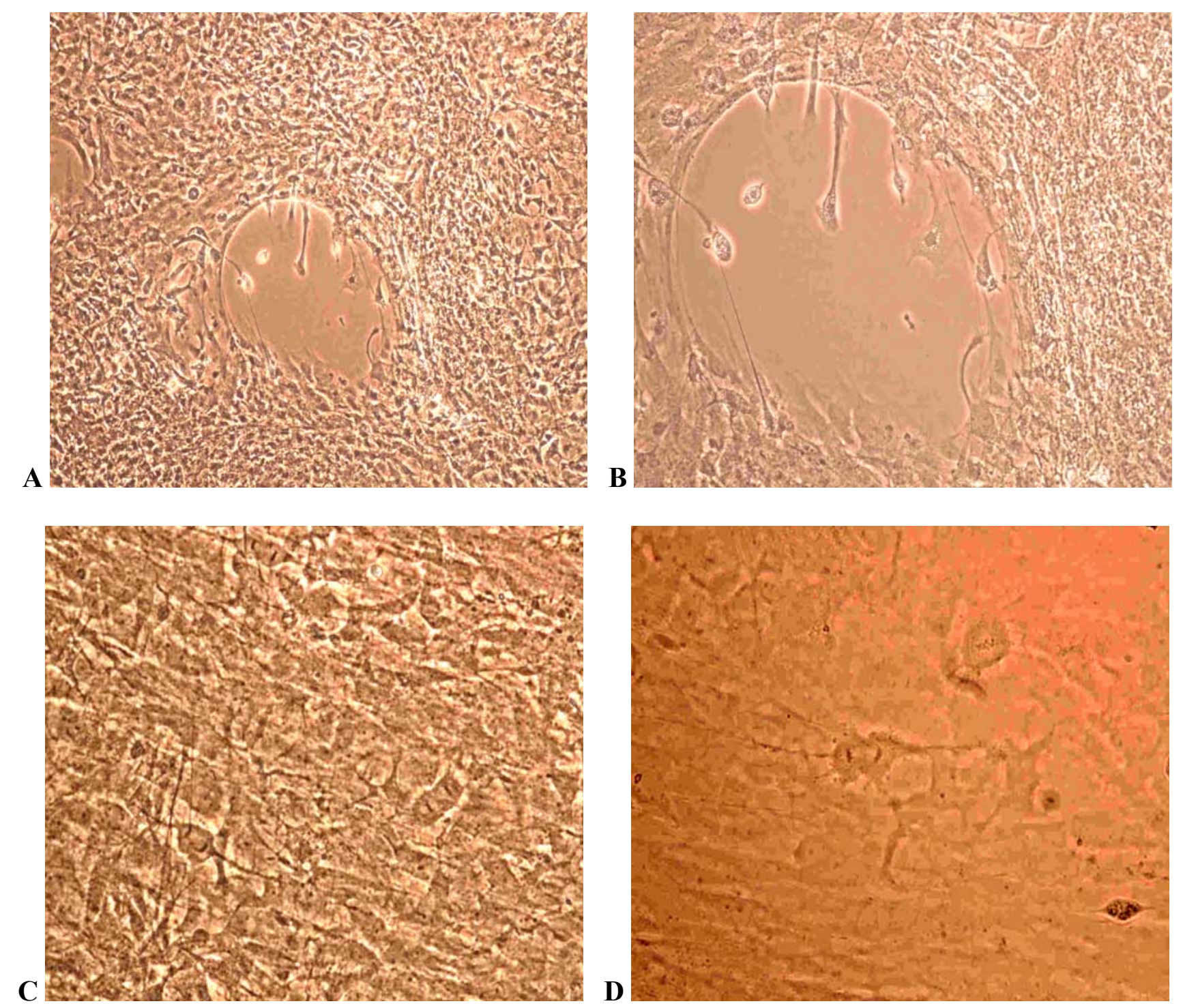

Fig. 22 Aspect de microscopie optică al culturii de 9 zile tratată cu LiCl $2 \mathrm{mM}$ (A- mărire x10, B- mărire x10, C- mărire x10, D- mărire x10)

În ziua a 9-a, creşterea diametrului insulelor celulare indică un nivel crescut al diviziunilor celulare (fig. 22 C-D), fiind de altfel observate numeroase celule surprinse în diferite etape ale ciclului mitotic. Apar orientãri în spațiu ale astrocitelor fibroase de tip II şi ale prelungirilor acestora (Fig. $22 \mathrm{C}$ ), fiind mimate aspecte tisulare. Golurile formate în monostratul de celule gliale sunt populate cu noi celule gliale. Culturile tratate cu $2 \mathrm{mM}$ $\mathrm{LiCl}$ prezintă deocamdatã puține celule cu caractere patologice, reprezentate de creşteri exagerate în volum şi vacuolizări. Situația generalã este foarte asemãnãtoare cu cea din cazul martor, ceea ce indicã faptul cã Li 2 mM nu genereazã încã efecte toxice. 


\section{LITIU 2 mM Ziua 10}
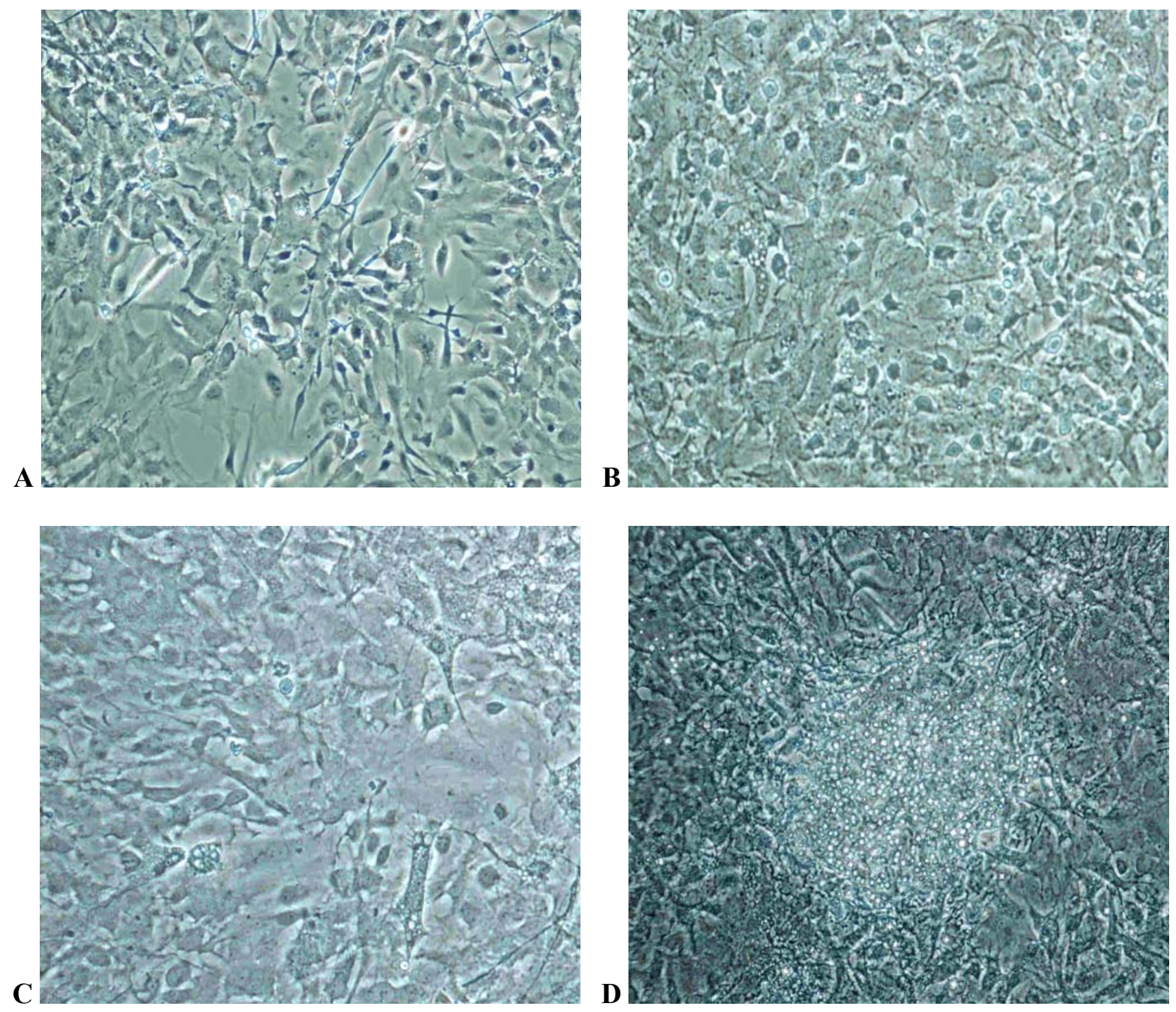

Fig. 23 Aspect de microscopie optică al culturii de 10 zile tratată cu LiCl $2 \mathrm{mM}$ (A- mărire x30 , B- mărire x30, C- mărire x30, D- mărire x30)

În ziua a 10-a, culturile tratate cu $2 \mathrm{mM} \mathrm{LiCl}$ prezintă un nivel maxim al confluenței, întreaga suprafațã de cultivare fiind acoperitã de stratul de celule gliale (fig. 23 A-D). Diviziunea celularã este, încã, uşor de observat prin surprinderea unor celule în diferite etape ale diviziunii mitotice (fig. 23 C). Un caracter particular, patologic, este apariția unor cristale în anumite centre ale culturii (fig. 23 D). Se poate analiza variabilitatea tipurilor de celule gliale prezente în culturã şi care conferã caracterul heterogen al acesteia (fig. 23 A-D). În aceastã zi are loc al treilea tratament cu LiCl $2 \mathrm{mM}$ al culturii. 


\section{LITIU 2 mM Ziua 12}
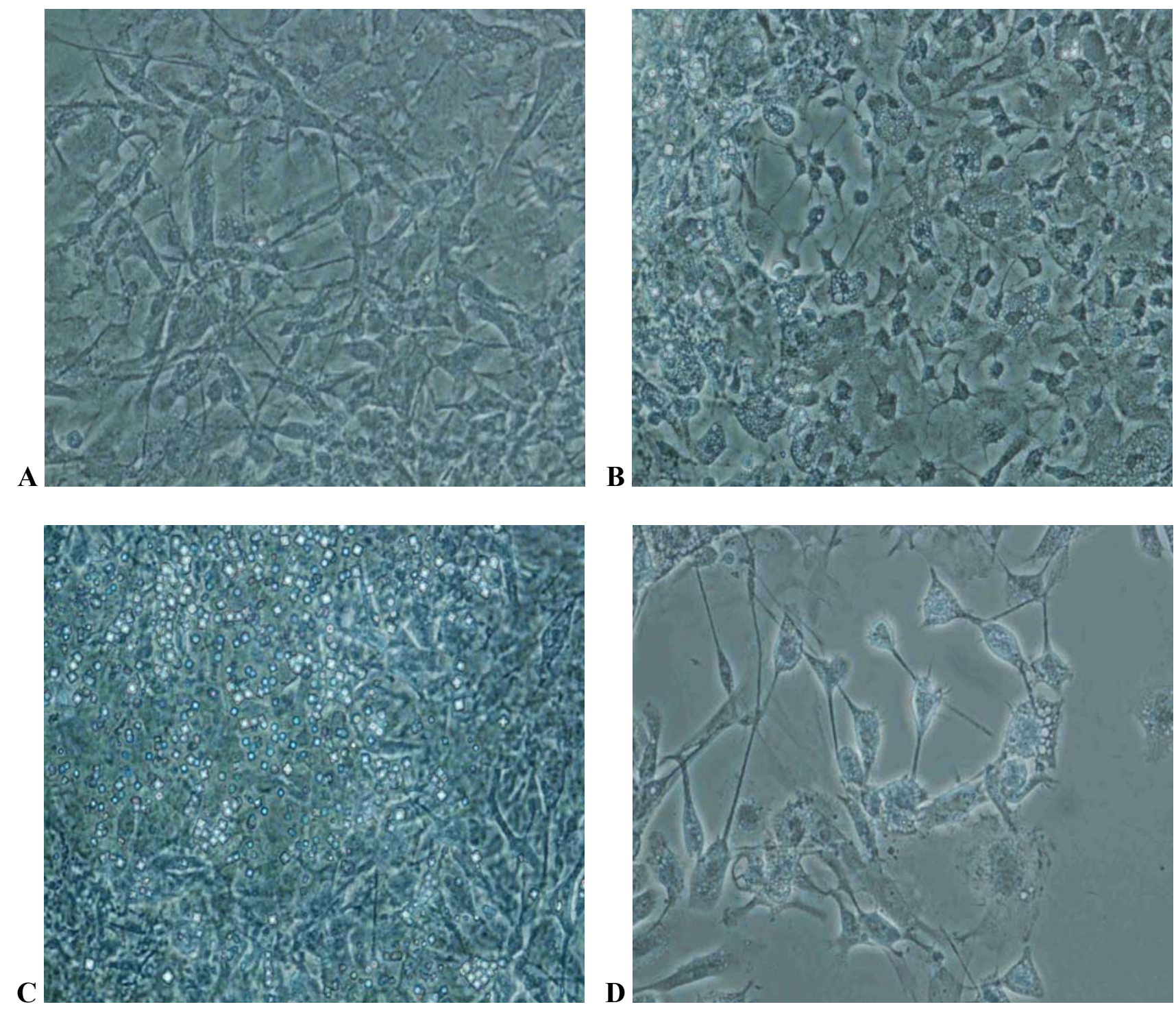

Fig. 24 Aspect de microscopie optică al culturii de 12 zile tratată cu LiCl $2 \mathrm{mM}$ (A- mărire x40, B- mărire x30, C- mărire x30, D- mărire x40)

În ziua a 12-a, cultura de celulele gliale tratată cu $2 \mathrm{mM} \mathrm{LiCl}$ se prezintă într-un stadiu confluent (fig. 24 A-C), dar cu zone cu resorbții celulare (fig. 24 D). Apar cu o frecvență mai mare resorbții celulare şi vacuolizãri (fig. 24 B, D) ceea ce indicã un nivel crescut al patogenitãții determinat de toxicitatea litiului. Un caracter patologic specific este apariția unor cristale în anumite centre ale culturii (fig. 24 C). Multiplicările celulare reflectã necesitãțile de menținere a confuenței monostratului de celule gliale. Se observă gradul ridicat al heterogenitãţii culturii (fig 24 A-D). În aceastã zi are loc al patrulea tratament cu $\mathrm{LiCl} 2 \mathrm{mM}$ al culturii. 


\section{LITIU 2 mM Ziua 15}
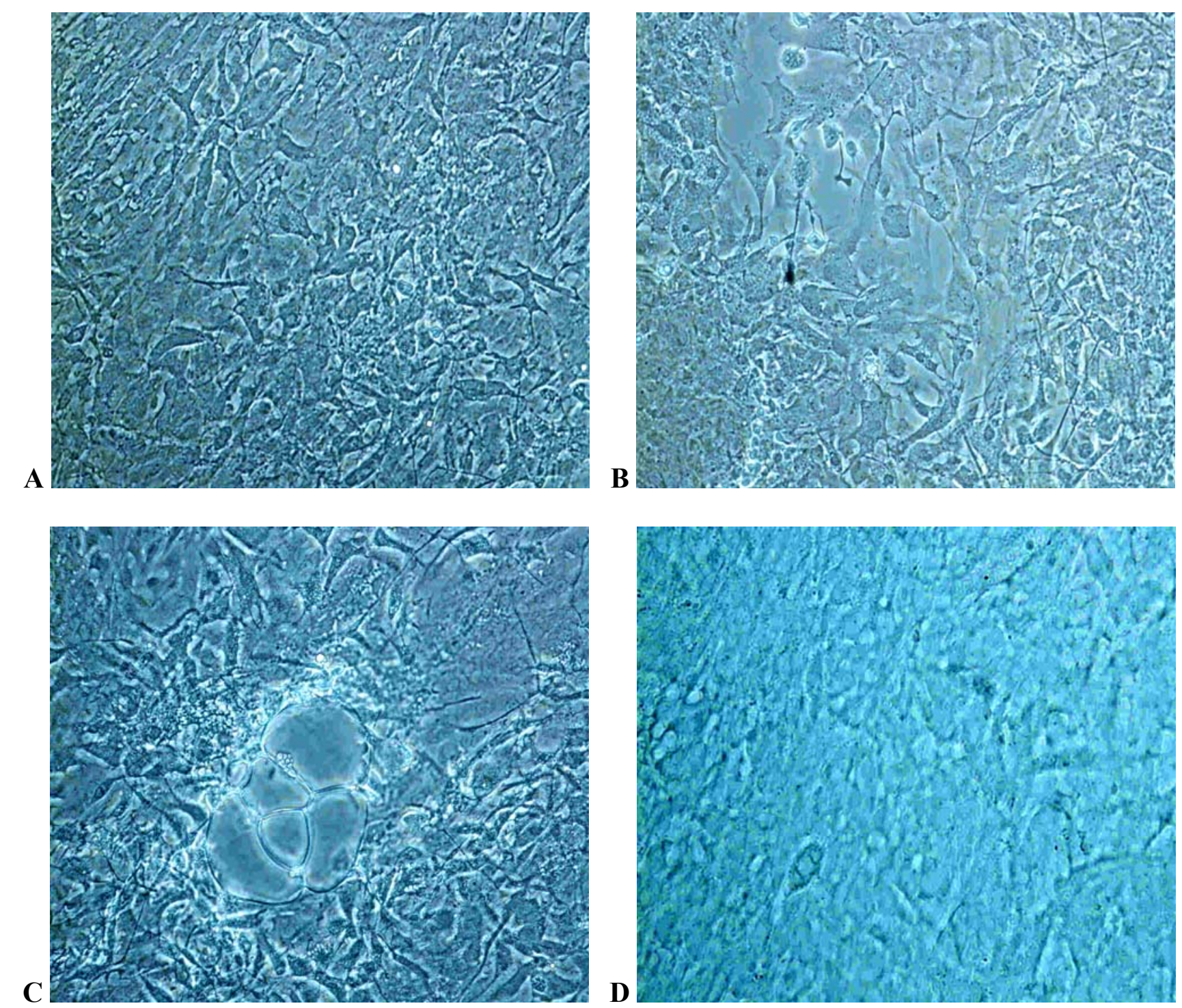

Fig. 25 Aspect de microscopie optică al culturii de 12 zile tratată cu LiCl $2 \mathrm{mM}$ (A- mărire x30 , B- mărire x30, C- mărire x30, D- mărire x30)

În ziua a $15-\mathrm{a}$, cultura de celulele gliale tratată cu $2 \mathrm{mM} \mathrm{LiCl}$ prezintă un aspect asemãnãtor cu cel descris în ziua precedentã, fiind menținut gradul de confluențã al culturii (fig. 25 A-D). Sunt mimate structuri tisulare complexe. Apar cu o frecvență crescută resorbții celulare. Multiplicările celulare pot fi observate încă prin observații microscopice (fig. 25 D). Se observă procese morfopatologice, generate de toxicitatea litiului la aceastã concentrație (fig. 25 B-C). La acest moment are loc stoparea creşterii, prelevarea mediului de culturã pentru analize biochimice şi pregãtirea culturii pentru obținerea omogenatului proteic total ce va reprezenta proba analizelor electroforetice şi pentru Western Blotting. 
Colorațiile histologice uzuale subliniază procesele morfopatologice determinate de tratamentul cu clorură de litiu la concentraţia de $2 \mathrm{mM}$. Aceste coloraţii au fost realizate după 10 sau 15 zile de cultivare. Caracterele morfopatologice observate cu o frecvență crescută sunt reprezentate de vacuolizări, creşteri în volum, apariția mai multor nuclei în celule, dezintegrarea insulelor de celule, pierderea formei celulare specifice celulelor gliale.

Rezultatele observate în urma administrării clorurii de litiu şi a apelor litinifere din sursa Maria sunt o continuare a studiilor anterioare privind acțiunea sărurilor de litiu, desfăşurate încă din anii ' 70 şi prezentate în literatura de specialitate.

La fel ca la lotul martor şi la cele tratat cu LiCl $1 \mathrm{mM}$ şi respectiv $2 \mathrm{mM}$, după realizarea monostratului (ziua 10 -11), multiplicarea celulară se reduce la rata strict necesară menținerii confluenței.

Clorura de litiu ( $\mathrm{LiCl}) 2 \mathrm{mM}$ exercită asupra celulelor gliale in vitro un efect mitogen stimulând diviziunea celulară. La celulele tratate cu LiCl $2 \mathrm{mM}$, procesul de diviziune celulară începe din ziua a treia şi continuă până în a 11-a -13-a zi de cultură, când se atinge faza de confluență. La lotul martor şi la cel tratat cu $1 \mathrm{mM} \mathrm{LiCl}$, procesele de diferenţiere şi diviziune sunt mai lente.

În urma cercetărilor efectuate am observat că durata efectului mitogen al LiCl este limitat. După 13-14 zile de cultură, la lotul tratat cu $2 \mathrm{mM} \mathrm{LiCl}$ apar alterări ale morfologiei celulare datorate probabil citotoxicităţii litiului. Celulele devin rotunde, hipertrofiate, citoplasma se granulează şi se vacuolizează. Se produce o scădere a numărului de prelungiri celulare concomitent cu scurtarea şi subțierea lor. Adesea, astrocitele devin atipice prin pierderea tuturor proceselor celulare cu excepția unei prelungiri hipertrofiate. Apar fenomene de liză celulară care determină apariţia de „ochiuri” în monostrat iar aspectul general al culturii este de rețea laxă. În ziua a 15-a se constată o scădere a adeziunii celulelor de placa de cultură şi desprinderea culturii în unele porțiuni.

Rezultatele obținute în urma acestui studiu demonstrează capacitatea litiului de a interfera cu dezvoltarea embrionară normală. Prin acțiunea sa asupra anumitor enzime implicate în căi de semnalizare embrionare, litiul induce efecte multiple la diferite niveluri. 


\section{Efectele apei minerale MARIA asupra morfologiei culturilor de celule gliale}

Celulele gliale cultivate în prezența apelor minerale bogate în litiu reprezintă modelul experimental pentru verificarea ipotezelor privind rolul acestora în îmbunătăţirea parametrilor de creştere a celulelor gliale in vitro.

Buletinele de analize al apei minerale MARIA au fost elaborate pe baza analizelor desfăşurate în cadul laboratorului LIAMNT (Laboratorul de Încercãri Ape Minerale şi Nãmoluri Terapeutice) al INRMFB.

Tratamentul cu apa minerală Maria presupune prepararea mediului de cultivare înlocuind o parte din apa bidistilată necesară în procesul de obținere cu apa minerală litiniferă Maria. Modelul experimental presupune utilizarea unor medii de tratament cu $50 \%$ şi $25 \%$ apă minerală Maria, ceea ce înseamnă practic înlocuirea a $50 \%$ şi respectiv a $25 \%$ din apa bidistilată necesară cu apa minerală Maria de la Malnaş-Băi.

Un al treilea caz pentru urmărirea efectelor apei îl constituie adăugarea la varianta cu $25 \%$ apă minerală Maria a unei concentrații de $1 \mathrm{mM} \mathrm{LiCl}$, pentru a monitoriza efectul creşterii cantităţii totale de litiu din apă.

Sterilizarea mediilor de cultură preparate cu apă minerală Maria şi utilizate în tratamentul culturilor de celule gliale se realizează prin filtrare prin membrană de nitroceluloză, cu diametrul porilor de $0,2 \mu \mathrm{m}$.

Schimbarea mediului şi aplicarea tratamentului cu apă minerală Maria, la concentraţia de 50\%, 25\% şi respectiv $25 \%+\mathrm{LiCl} 1 \mathrm{mM}$, are loc la o frecvenţă de douãtrei zile de cultivare.

Tratamentul cu apa Maria a început din ziua a 6-a de cultivare a celulelor gliale, după faza de lag, moment ce corespunde startului formãrii insulelor celulare şi a diferențierii celulare pronunțate.

Alegerea concentrațiilor de apă s-a făcut în corelație cu capacitatea fiziologică de ingestie de apă a organismului, sub ipoteza că în sânge se poate înlocui în 24 de ore maxim $25 \%$ din volumul serului cu apa consumată zilnic (1,5 - 2 litri apă pe zi), urmând a fi filtrat şi eliminate sărurile la nivel renal, digestiv şi prin piele.

Concentrația de 50\% apă minerală Maria este aleasă numai în scopul experimental de a urmări efectul pe care acest nivel foarte ridicat îl are asupra celulelor gliale in vitro. Acest nivel nu are nici o valoare terapeutică, deoarece organismul nu are cum să dispună de o cantitate de apă consumată atât de mare.

Din punct de vedere experimental, concentraţia de 50\% reprezintă un control pozitiv asupra efectelor pe care apa minerală Maria le poate avea asupra celulelor.

Datele experimentale obținute preliminar, în cadrul studiilor noastre, au arătat că prin înlocuirea $100 \%$ a apei bidistilate necesare în procesul tehnologic de preparare a mediului de cultivare a celulelor gliale în cultură, are loc distrugerea culturii în $48-72$ de ore de la aplicare. S-a constatat astfel că apa minerală Maria, ca atare, nu poate asigura condițiile minimale pentru supraviețuirea in vitro a celulelor gliale. 


\title{
Localitatea: Malnaş-Băi \\ Județul: Covasna \\ Sursa: Izvorul Maria
}

Buletin de analize al apei minerale MARIA

\author{
Vizat \\ Director General \\ Dr. Iaroslav Kiss
}

Data recoltării: aprilie 2004

Temperatura apei: ${ }^{\circ} \mathrm{C}$

Temperatura aer: ${ }^{\circ} \mathrm{C}$

Densitatea la $20^{\circ} \mathrm{C}: 1,0060 \mathrm{~g} / \mathrm{cm}^{3}$

Salinitate: 5,8

$\mathrm{pH}: 6,5$

Rezistivitatea electrică: $97,9527 \mathrm{~cm} \Omega$

Conductivitatea electrică: $0,0102 \mathrm{~cm}^{-1} \Omega^{-1}$

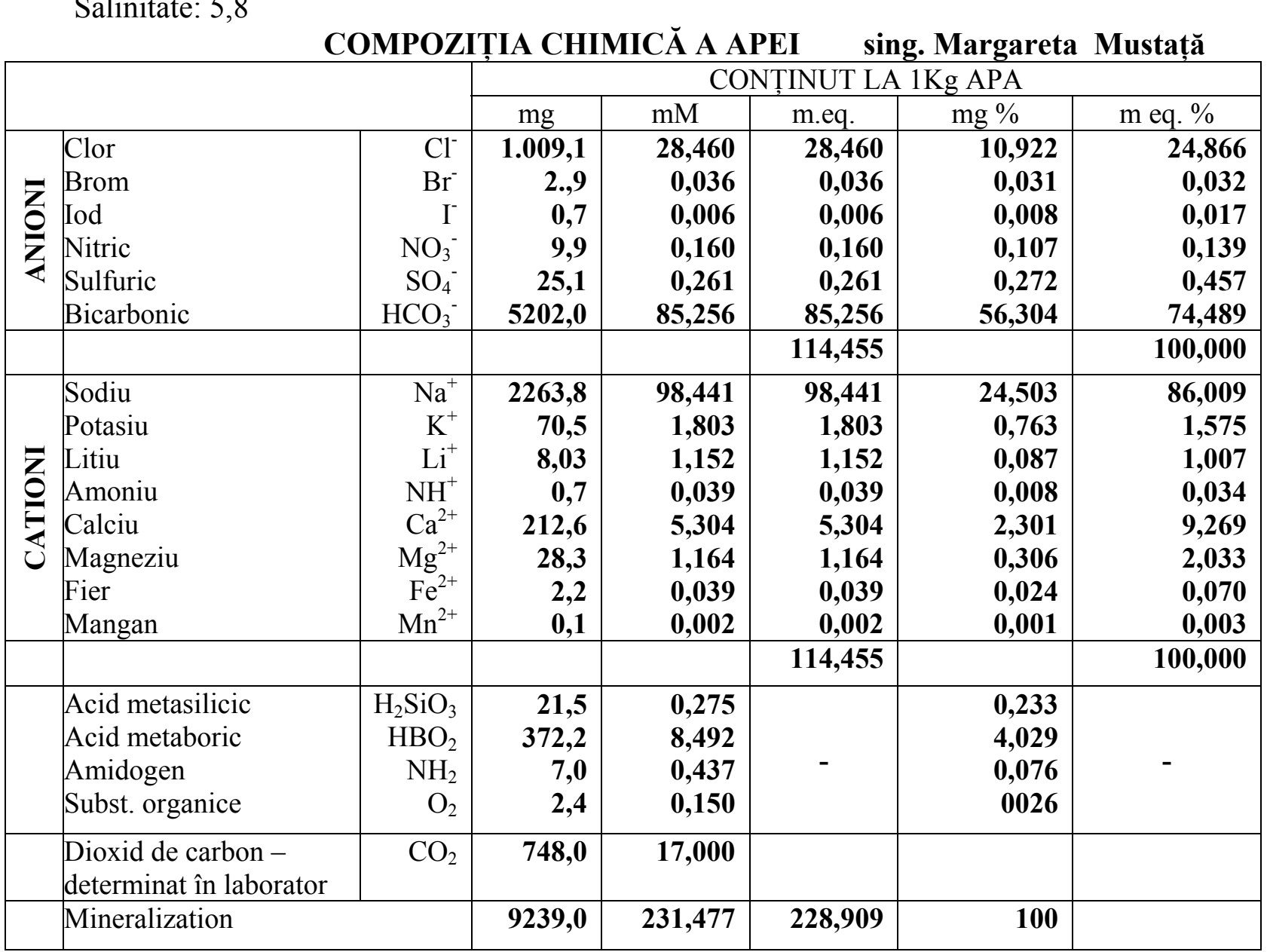

Caracterizarea apei: apă minerală litiniferă, bicarbonatată, clorurată, sodică, carbogazoasă, hipotonă 


\section{Localitatea: Malnaş-Băi}

\section{Buletin de analize al apei minerale MARIA}

\section{Județul: Covasna}

Sursa: Izvorul Maria

\section{Vizat \\ Director General \\ Dr. Delia Cintezã}

\section{Sursa: Iavorul Maria}

Data recoltării: septembrie 2008

Temperatura apei: ${ }^{\circ} \mathrm{C}$

$\mathrm{pH}: 6,5$

Temperatura aer: ${ }^{\circ} \mathrm{C}$

Densitatea la $20^{\circ} \mathrm{C}: 1,0059 \mathrm{~g} / \mathrm{cm}^{3}$

Salinitate: 5,6

Rezistivitatea electrică: $97,9527 \mathrm{~cm} \Omega$

Conductivitatea electrică: $963300 \mu \mathrm{S}$

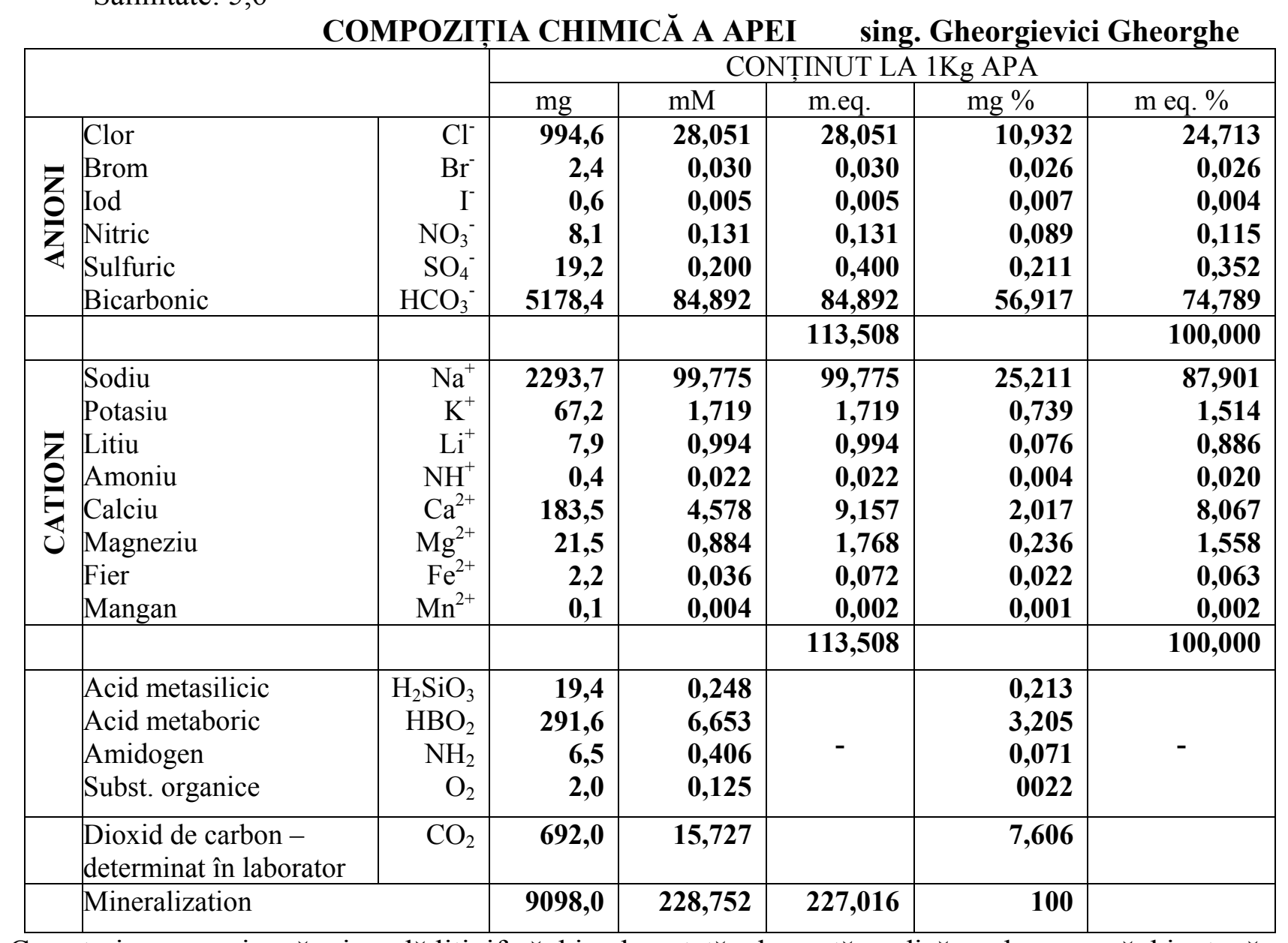

Caracterizarea apei: apă minerală litiniferă, bicarbonatată, clorurată, sodică, carbogazoasă, hipotonă 


\section{Grafice de modificare a compoziției chimice a apei minerale Maria}
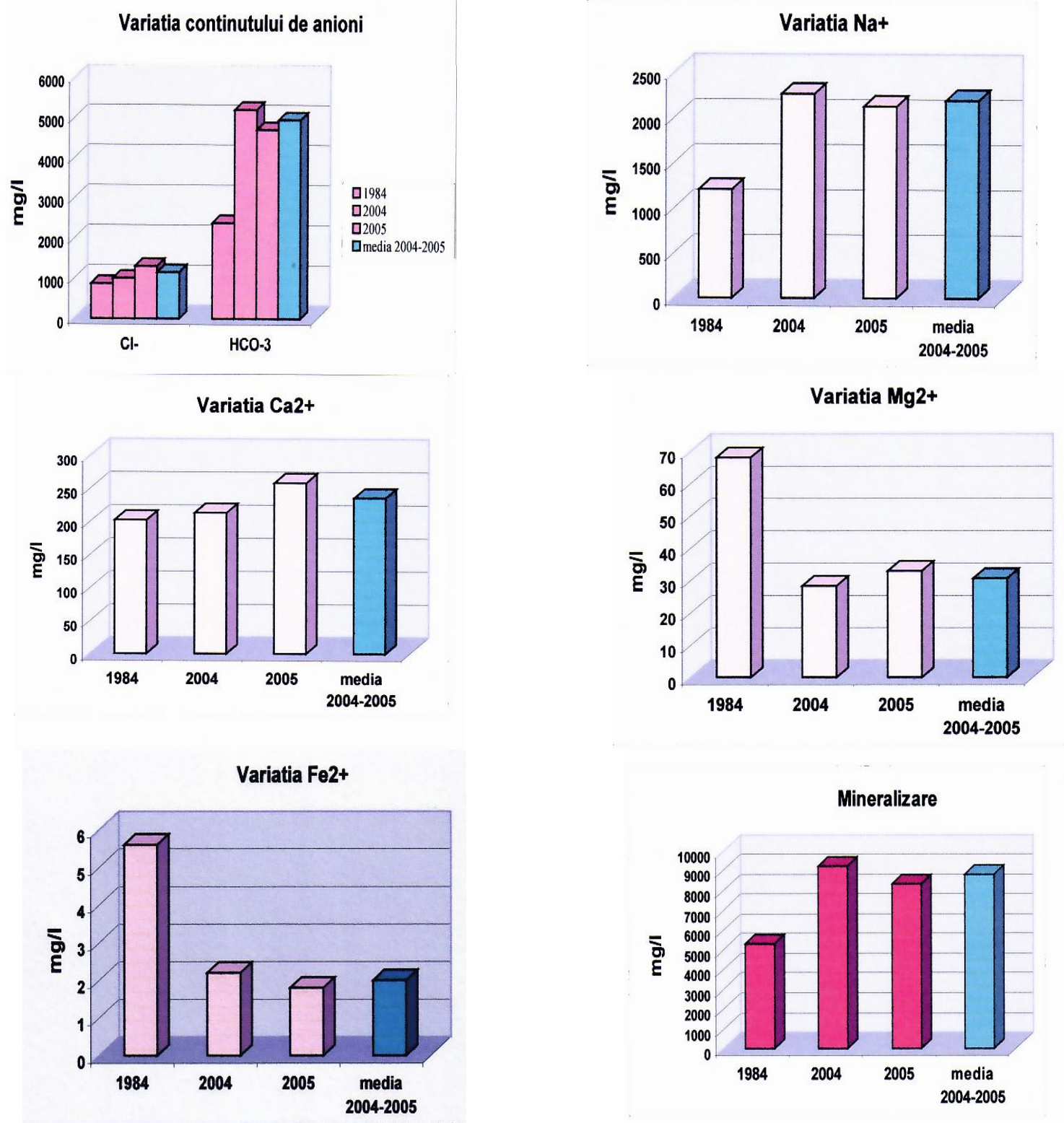

Grafice de modificare a concentrației unor ioni din apa minerală Maria de la Malnaş Băi

Concluziile acestui studiu relevã faptul cã mineralizarea apei minerale Maria s-a schimbat în ultimii 20 de ani, atât în privința anionilor, cât şi a cationilor.

Semnificative sunt creşterile ionilor de carbonat acid şi sodiu, dar şi scãderile de magneziu şi de fier.

Litiul nu a fost determinat la nivelul anului 1984, dar se poate considera ca nivelul acestuia a crescut într-o manierã asemãnãtoare ionului de sodiu. Aşa cum se poate observa din grafic, nivelul acestuia s-a dublat în aceşti ultimi 20 de ani.

Concentrația de litiu determinată în 2004, situatã la valoarea de 8,03 mg la litru are rolul de a conferi atributul de apa minerală litiniferă, din care decurg o serie de proprietăți terapeutice identificate în urma cercetărilor desfăşurate. 


\section{M50-ziua 7}
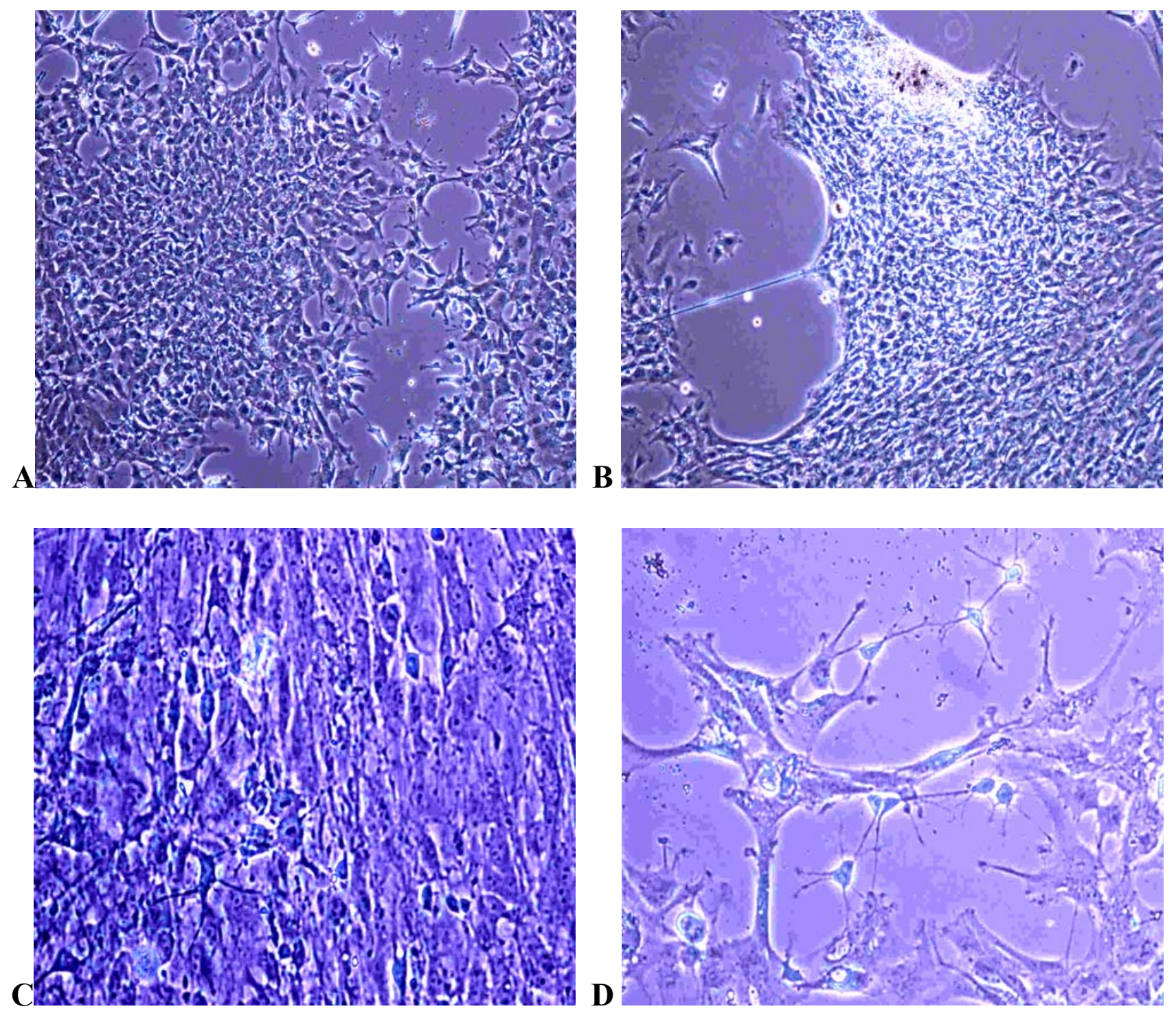

Fig. 26 Aspecte de microscopie optică ale culturii de 7 zile tratată cu apã MARIA 50\%

(A-mărire x10 - insulã de celule, B- mărire x10 - aspect tridimensional, C- mărire x30 - insulã de celule, Dmărire $\mathrm{x} 40$ )

În primele 24 de ore de tratament cu apa mineralã Maria 50\%, cultura de celule gliale în ziua a 7-a nu prezintă modificări morfologice semnificative faţă de martor. Se observă o creştere în lungime a prelungirilor celulare. Creşte de asemenea nivelul interconexiunilor celulare. Multiplicările se produc cu o ratã asemănătoare cazului martor, la nivelul insulelor celulare formate şi mai puțin în afara acestora (fig.26 C). Celulele gliale din culturã prezintã morfologii variate (fig. 26 C şi D), celulele aparținând astrocitelor, oligodendrocitelor sau microgliilor. 


\section{M50-ziua 8}
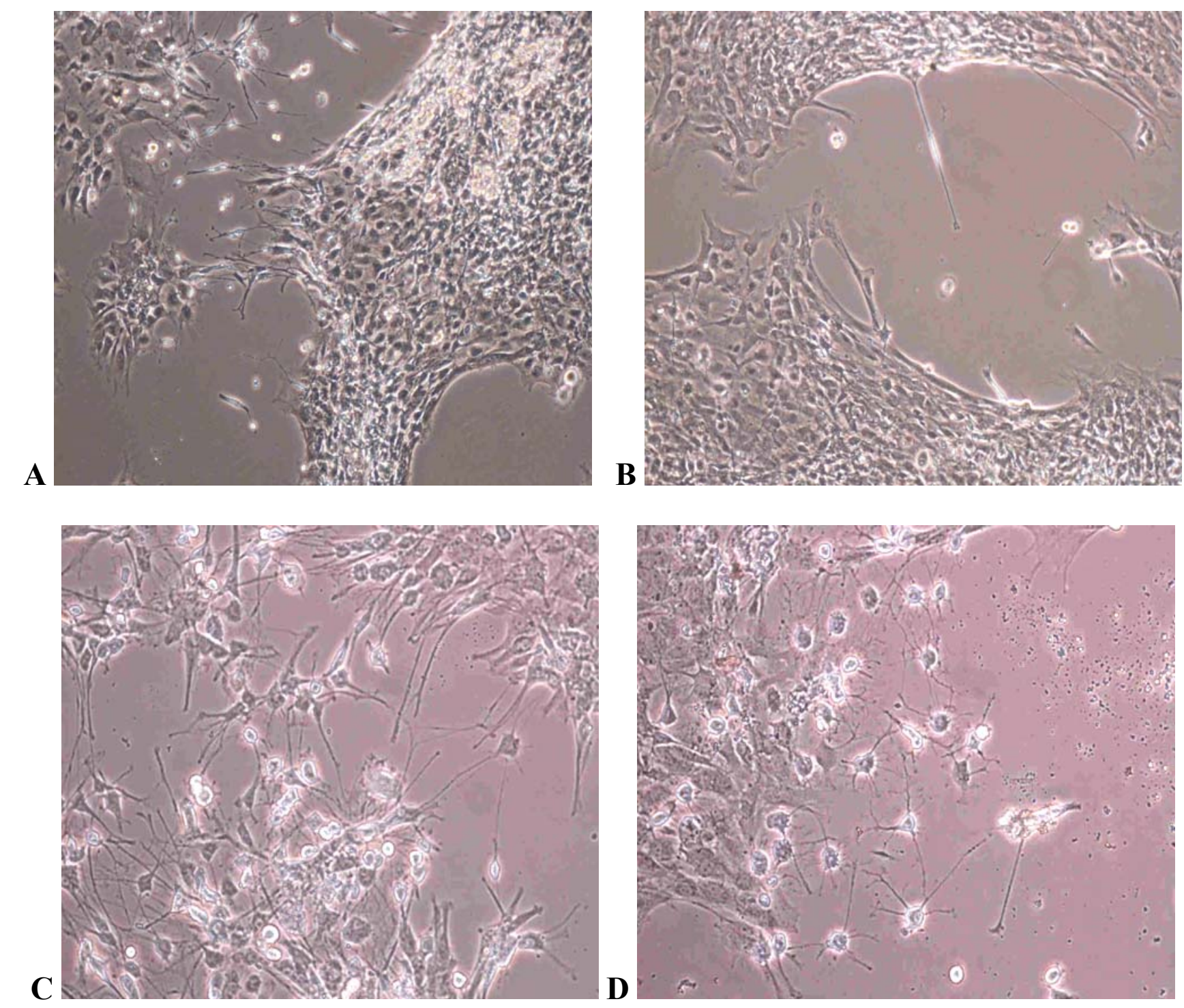

Fig. 27 Aspect de microscopie optică ale culturii de 8 zile tratată cu apã MARIA 50\% (A- mărire x10, B- mărire x10- insulã de celule, C- mărire x40 - insulã de celule, D- mărire x40)

În ziua a 8-a a culturii de celule gliale tratatã cu apă minerală Maria $50 \%$ sunt observate modificări morfopatologice de tipul creşterilor în volum, creşterea prelungirilor celulare şi vacuolizare (fig. 27 C, D). Multiplicările celulare sunt inhibate, observându-se creşterea gradului de diferențiere a celulelor gliale din culturã şi stagnarea creşterii dimensiunii insulelor celulare. În cadrul monostratului apar numeroase goluri, ca urmare a desprinderii celulelor din marginea insulei de substrat şi ridicarea foiței de celule gliale (fig. 27 A). Se remarcã o creştere a heterogenitãții culturii, ca rezultat al avansãrii procesului de diferenţiere şi maturare celularã. Acest aspect este generat de adaptarea celulelor gliale la factorii de mediu şi încercarea lor de a supraviețui. 


\section{M50-ziua 10}
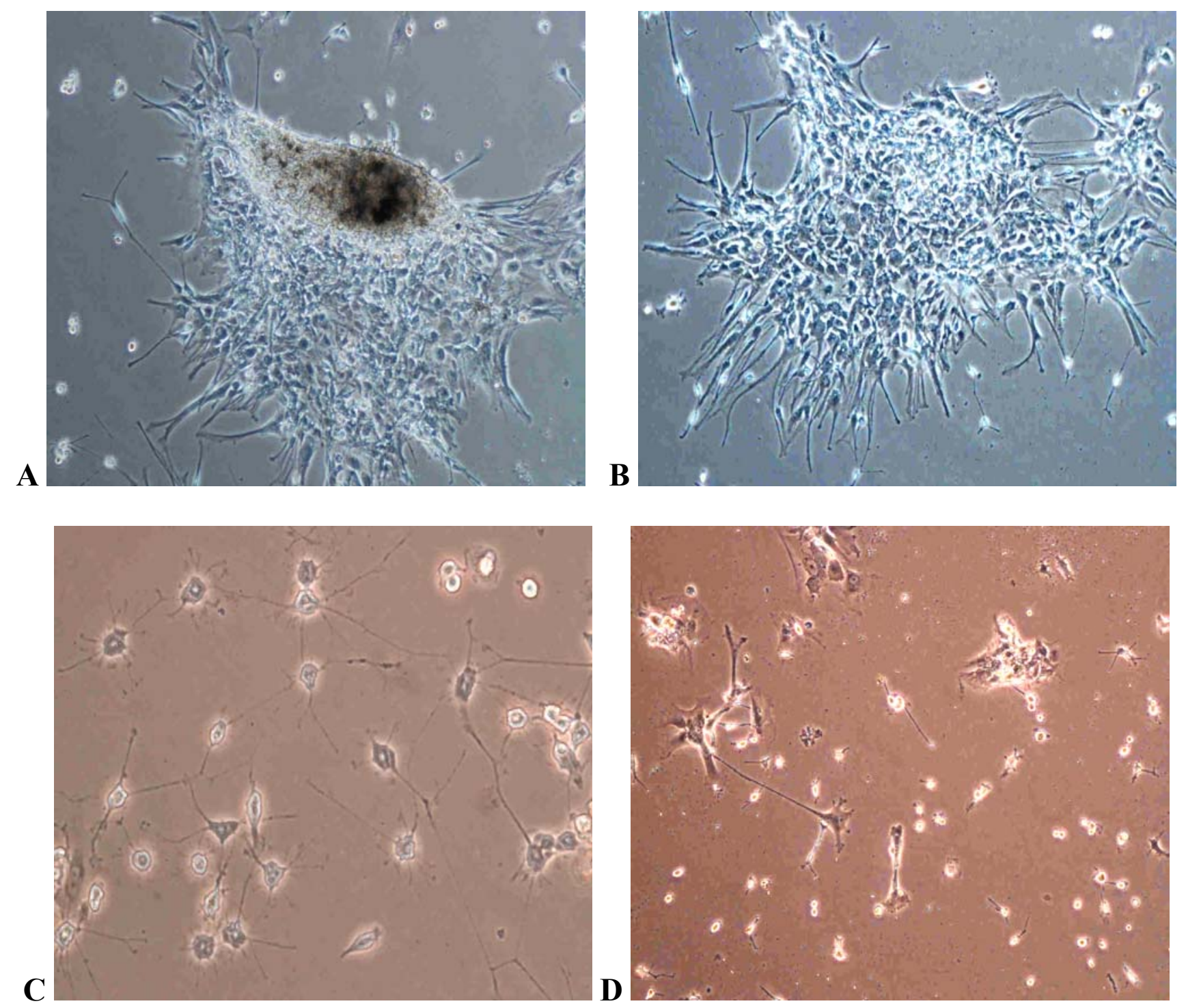

Fig. 28 Aspecte de microscopie optică ale culturii de 10 zile tratată cu apã MARIA 50\% (A- mărire x15 - insulã de celule, B- mărire x15, C- mărire x30, D- mărire x15)

În a 10-a zi de cultivare a celulelor gliale se observă că celulele supraviețuitoare se adaptează mediului modificat al apei minerale Maria 50\% (fig. 28 A-D). Deşi sunt observate foarte puține multiplicări celulare, se reformează insule celulare mai mici, formate din zeci sau sute de celule gliale. Unele celule, probabil dintre cele apărute în urma diviziunilor celulare prezintă prelungiri celulare tipice celulelor gliale dar mai groase. Observațiile microscopice arată o adaptare a celulelor supraviețuitoare şi încercarea lor de refacere a structurilor existente anterior (fig. 28 A-D). În ziua a zecea, culturile gliale primesc al treilea tratament cu apã Maria 50\%. 


\section{M50-ziua 11}
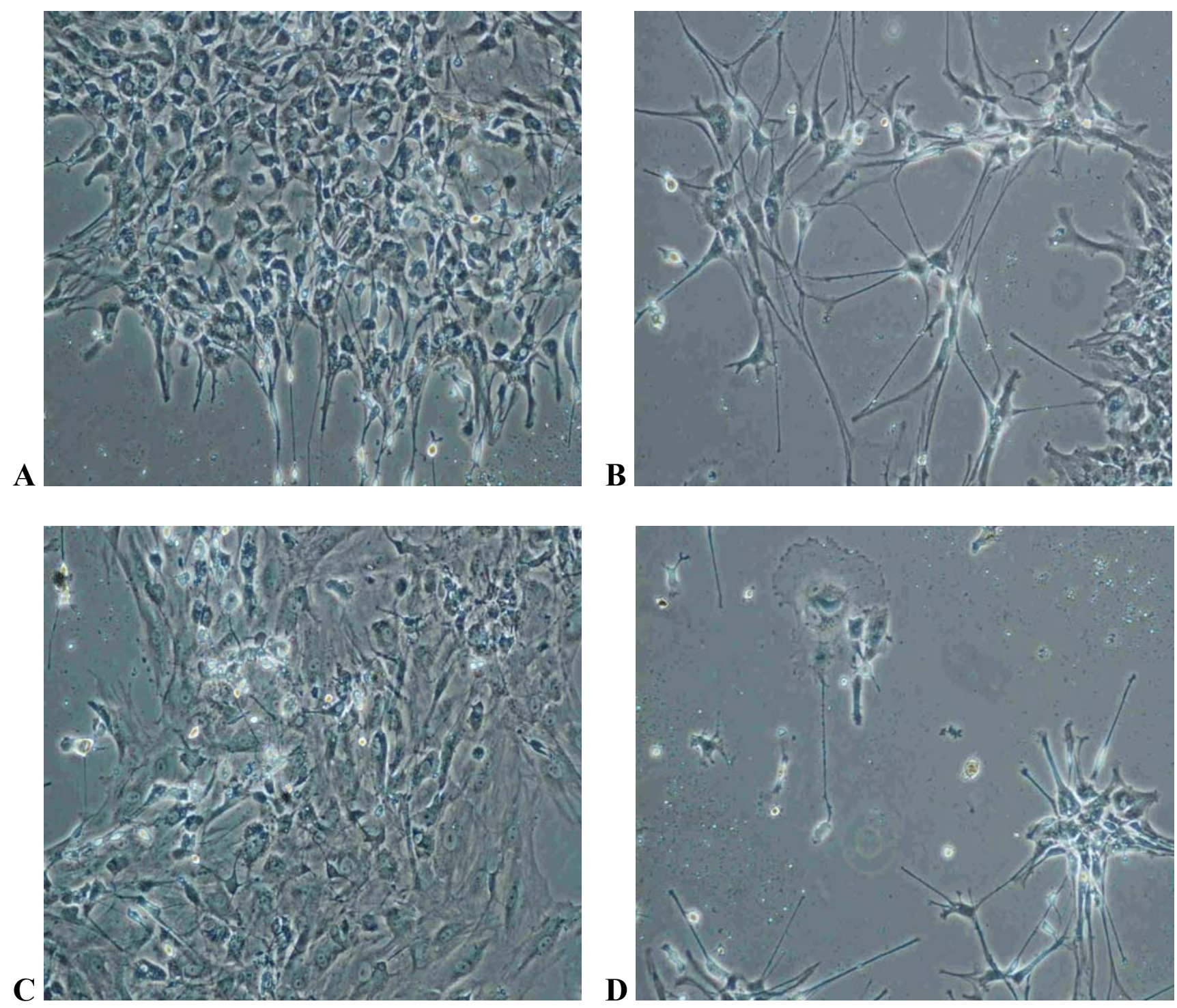

Fig. 29 Aspecte de microscopie optică ale culturii de11 zile tratată cu apã MARIA 50\% (A- mărire x30, B- mărire x30, C- mărire x30, D- mărire x30)

Aplicarea celui de-al treilea tratament cu apă minerală Maria 50\% în ziua precedentã are efecte majore asupra celulelor gliale, provocând degradarea necrotică a mai multor celule, caracterizată prin creşteri foarte mari în volum, vacuolizări şi apariţia celulelor cu mai mulți nuclei (fig. 29 C-D). În cazul celulelor supraviețuitoare se observã creşterea semnificativã a proceselor celulare şi încercarea celulelor de a se contacta prin intermediul sinapselor, chiar şi atunci când distanţa dintre ele este foarte mare (fig. 29 B,D). Diviziunile celulare nu sunt observate. 


\section{M50-ziua 12}
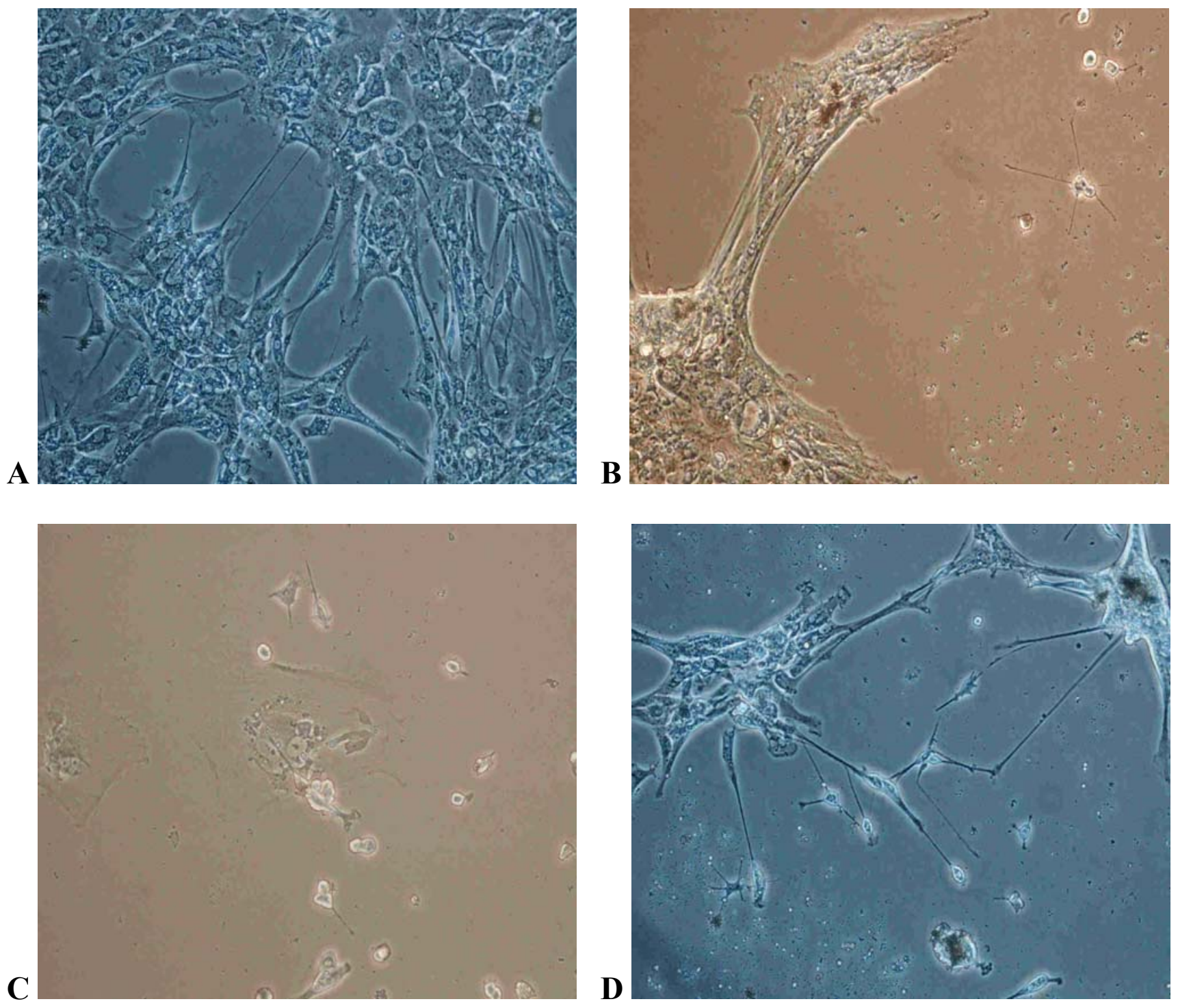

Fig. 30 Aspecte de microscopie optică ale culturii de12 zile tratată cu apã MARIA 50\%

(B- mărire x15, B- mărire x15, C- mărire x15, D- mărire x15)

Aplicarea celui de-al patrulea tratament cu apă minerală Maria 50\% în ziua a 12-a menține starea necrotică a celulelor gliale (fig. $30 \mathrm{C}$ ). Sunt încă celule care supraviețuiesc şocului şi care vor fi lizate în vederea obținerii schiței electroforetice şi a expresiei unor proteine prin tehnica Western blotting. Moartea celularã şi maturarea celularã avanstã, însoțitã de fenomenul de senescențã celularã, determinã reducerea nivelului de heterogenitate al culturii. Analiza microscopicã a culturii relevã prezența unor celule $\mathrm{cu}$ prelungiri lungi şi îngroşate, aflate în contact sinaptic cu celule din vecinãtate (fig. 30 D). Cultura de celule gliale prezintã încã un numãr de 5-6 insule de celule, formate din câteva sute de celule, cu un nivel morfopatologic avansat (fig. 30). 


\section{M50-ziua 13}
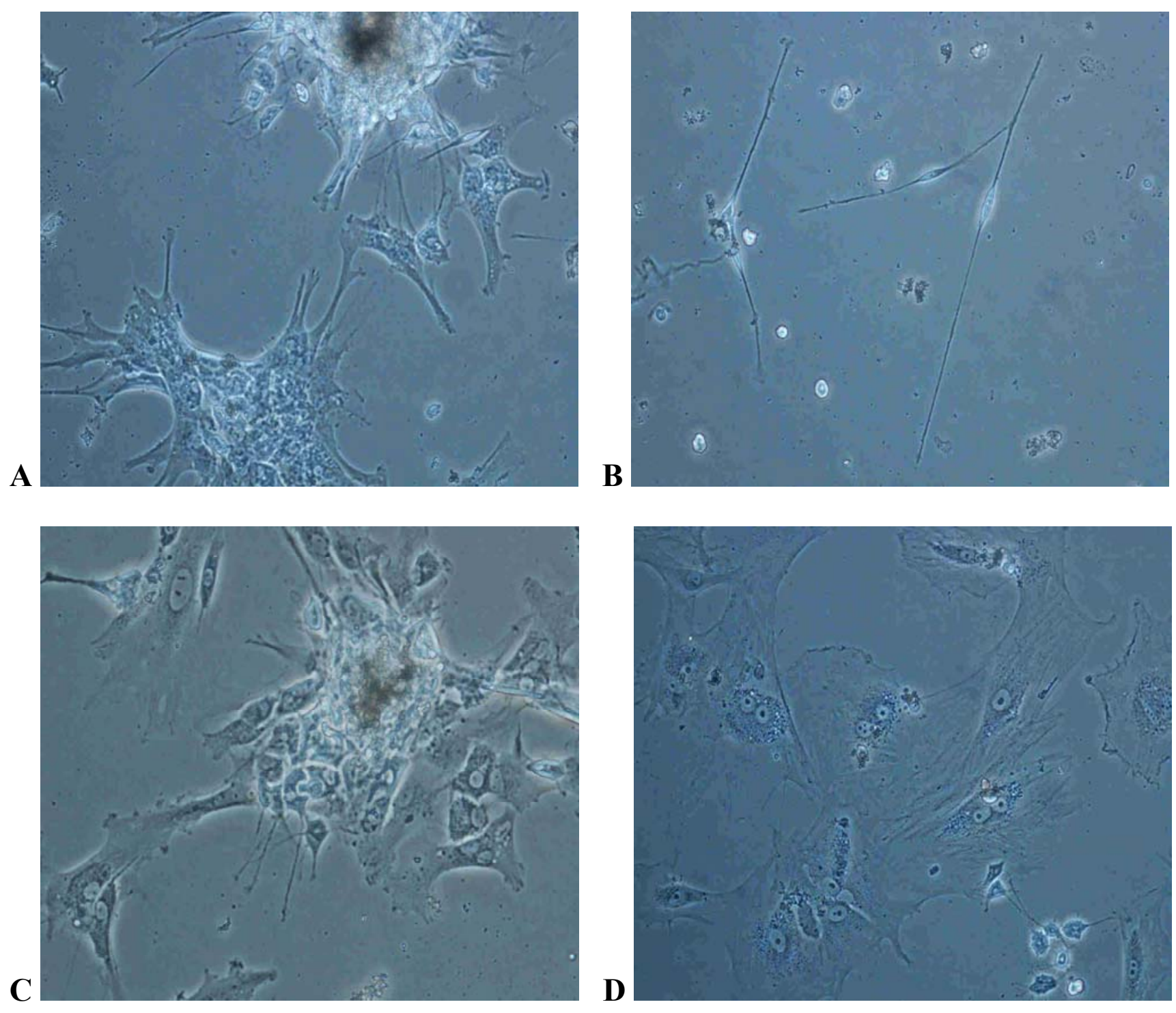

Fig. 31 Aspecte de microscopie optică ale culturii de 13 zile tratată cu apã MARIA 50\%

(C- mărire x15, B- mărire x20, C- mărire x30, D- mărire x20)

În ziua a 13-a a culturii gliale ce a primt al patrulea tratament cu apă minerală Maria 50\% prezintã o stare necrotică profundă caracterizată prin creşteri foarte mari în volum, vacuolizări, apariția celulelor cu mai mulți nuclei (fig. 31 A-D). Sunt observate celule gliale cu prelungiri celulare foarte lungi, prin care sinapseazã cu alte celule. Insulele celulare îşi pierd limitele şi capãtã aspectul unor grupuri de celule dispersate în spaţiul ocupat de vechea insulã (fig. $31 \mathrm{~A}, \mathrm{C}$ ). Procesele necrotice sunt foarte frecvente şi caracterizeazã aproape întreaga suprafațã de cultivare (fig. 31 D). 


\section{M50-ziua 14}
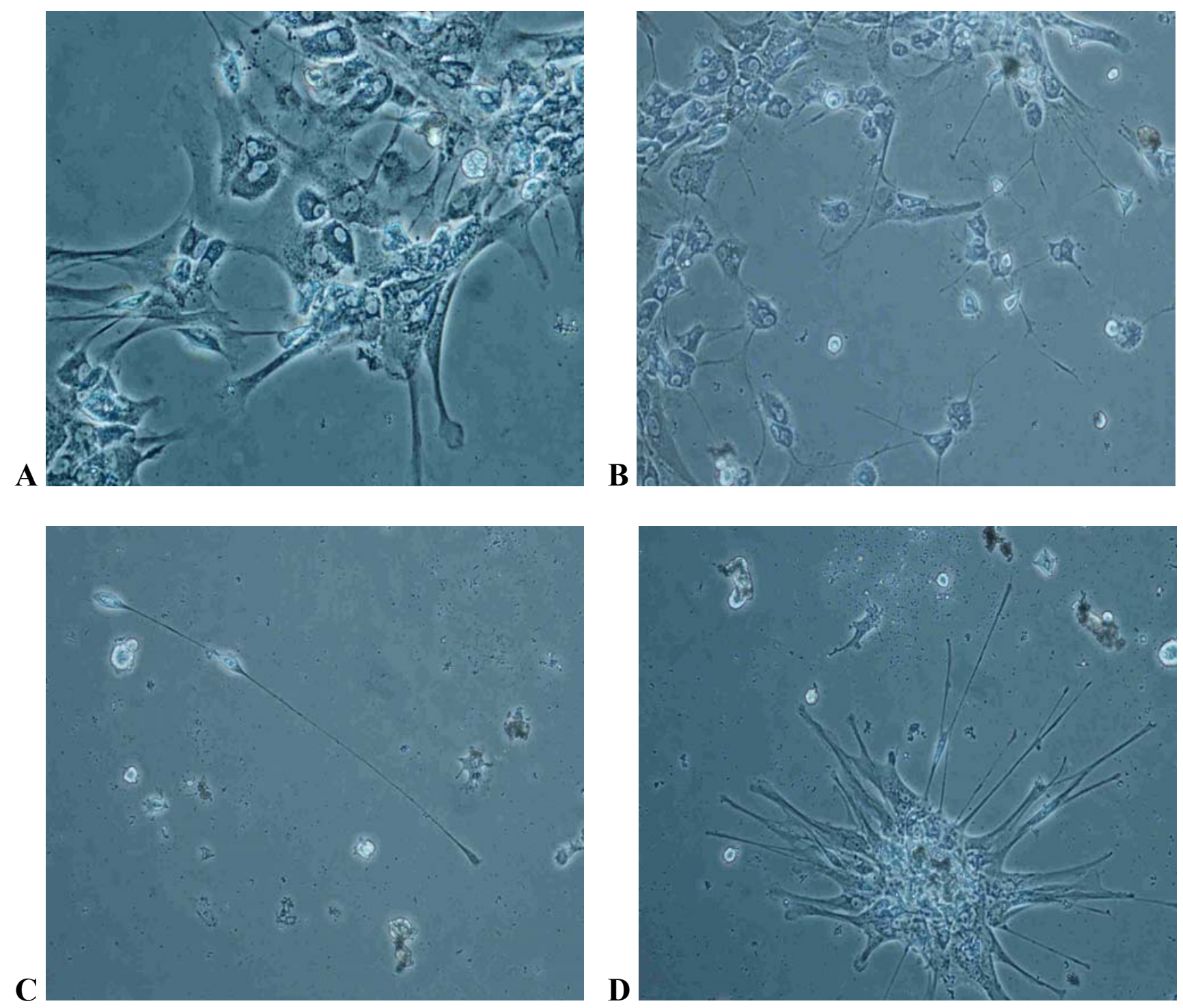

Fig. 32 Aspecte de microscopie optică ale culturii de 14 zile tratată cu apã MARIA 50\% (D- mărire x20, B- mărire x15, C- mărire x10, D- mărire x10)

Aplicarea celui de-al cincilea tratament cu apă minerală Maria 50\% în ziua a 14a nu schimbã foarte mult aspectul general al culturii, prezentat pentru ziua anterioarã (fig. 32 A-D). Este observatã aceeaşi stare necrotică profundă caracterizată prin creşteri foarte mari în volum, vacuolizări şi apariția celulelor cu mai mulți nuclei. 


\section{M50-ziua 15}

A
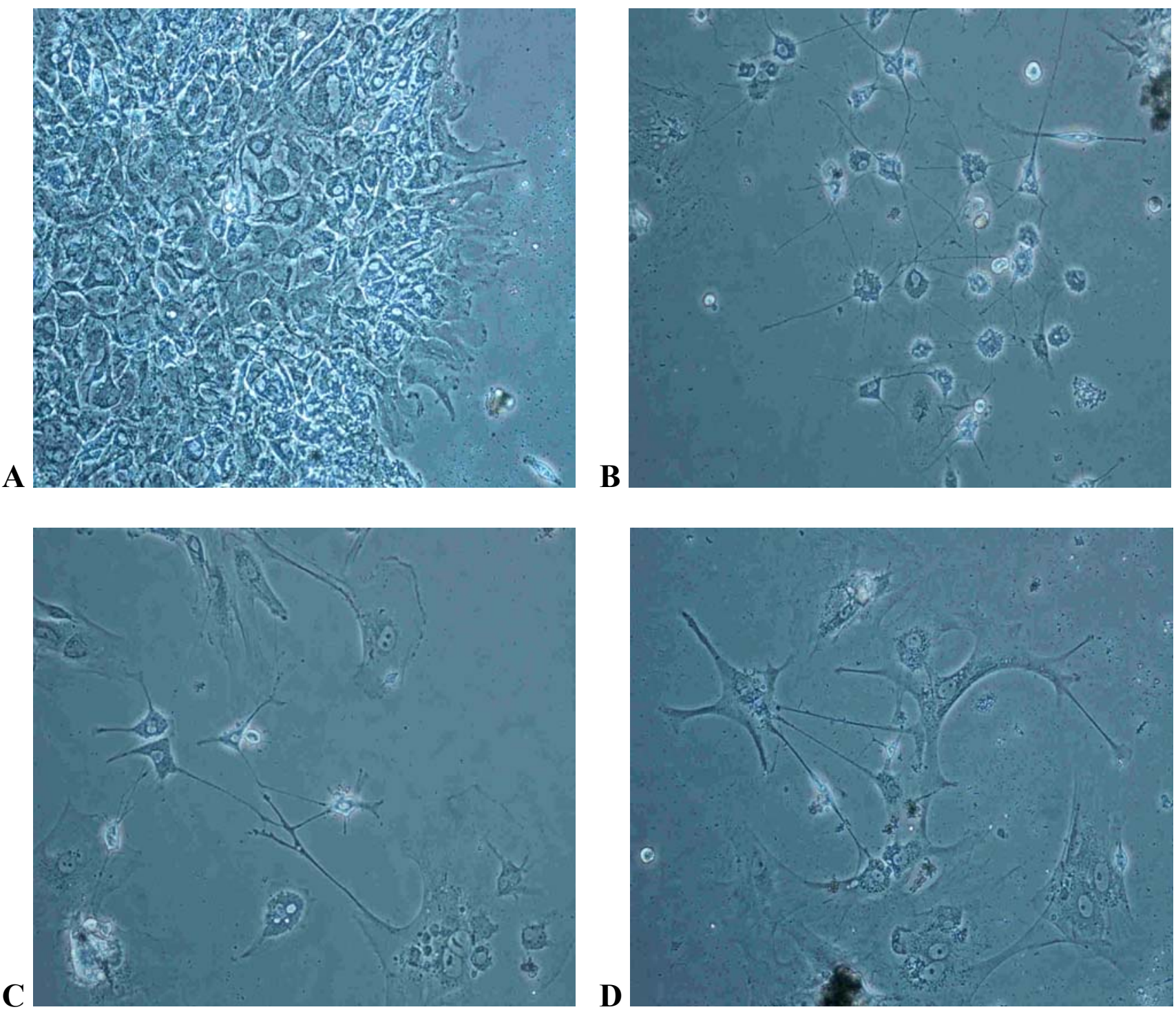

D

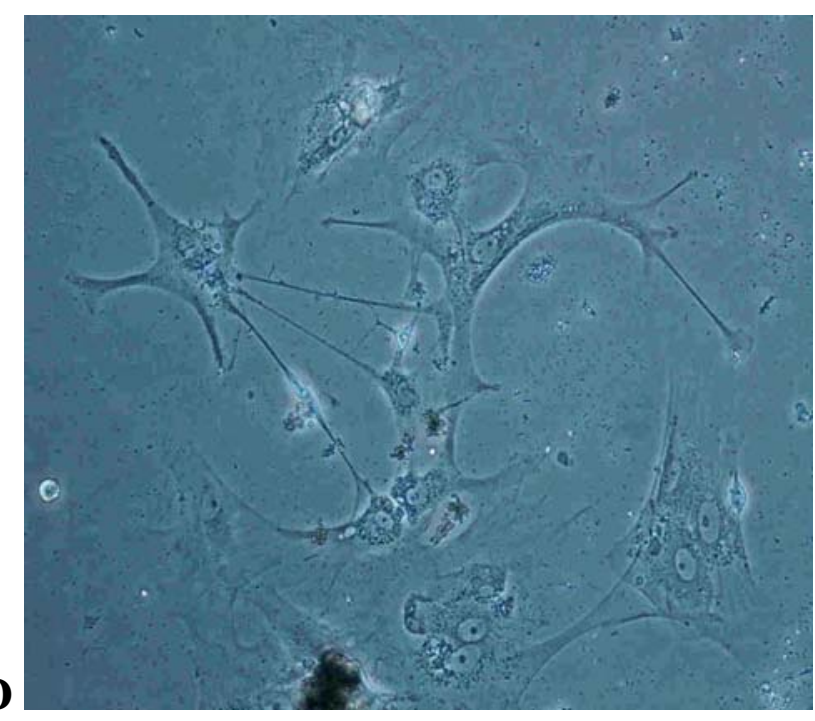

Fig. 33 Aspect de microscopie optică al culturii de 15 zile tratată cu apã MARIA 50\% (E- mărire x10 , B- mărire x20, C- mărire x40, D- mărire x20 -aspect tridimensional)

În ziua a 15-a a culturii de celule gliale tratatã cu apã mineralã Maria $50 \%$ se observã un nivel necrotic similar cu cel din ziua precedentã (fig. 33 A-D). Celulele gliale ce au supraviețuit tratamentului cu apã Maria 50\% şi s-au adaptat la condiţiile impuse de acest factor extern, prezintã prelungiri celulare lungi şi îngroşate prin care comunicã sinaptic cu celule gliale aflate în vecinãtate, dar la o distanțã mai mare decât în mod obişnuit (fig. 33 C, D). La acest moment are loc stoparea creşterii, prelevarea mediului de culturã pentru analize biochimice şi pregãtirea culturii pentru obținerea omogenatului proteic total ce va reprezenta proba analizelor electroforetice şi pentru Western blotting. 


\section{M25-ziua 7}
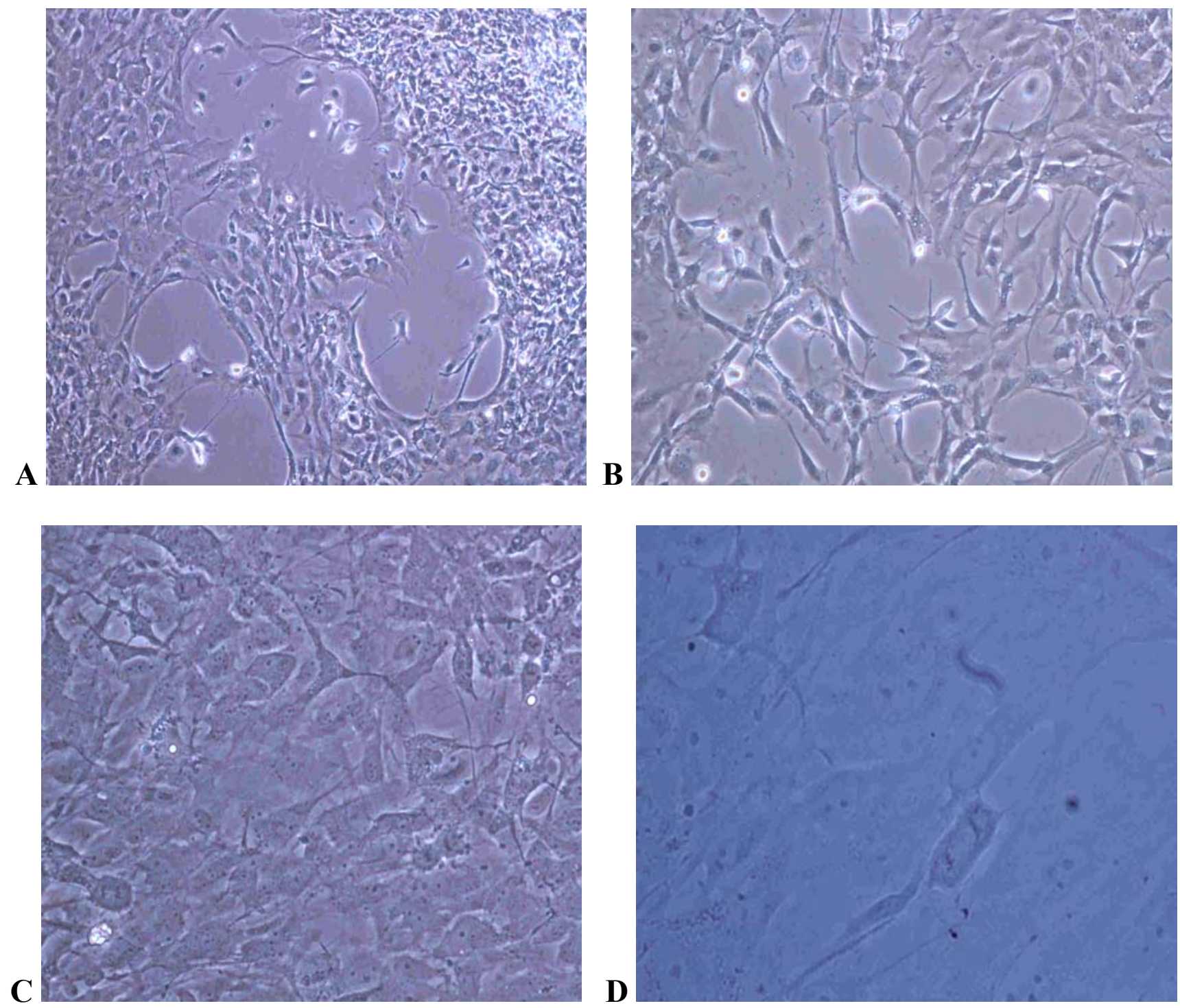

Fig. 34 Aspecte de microscopie optică ale culturii de 7 zile tratată cu apã MARIA 25\% (A-mărire x10, B- mărire x20, C- mărire x30 - insulã de celule, D- mărire x40)

În primele 24 de ore de tratament cu apa mineralã Maria 25\%, cultura de celule gliale ajunsă în cea de a 7-a zi, nu prezintă modificări morfologice semnificative faţă de martor, fiind înregistrat un nivel avansat de preconfluențã (fig 34, A-B). Aspectele interesante observate în acest caz țin de o anumită orientare a prelungirilor celulare ale unor grupuri de celule gliale. Multiplicările celulare (fig 34, C-D) se produc cu o rata asemănătoare cazului martor, la nivelul insulelor celulare formate şi mai puțin în afara acestora. 


\section{M25-ziua 9}
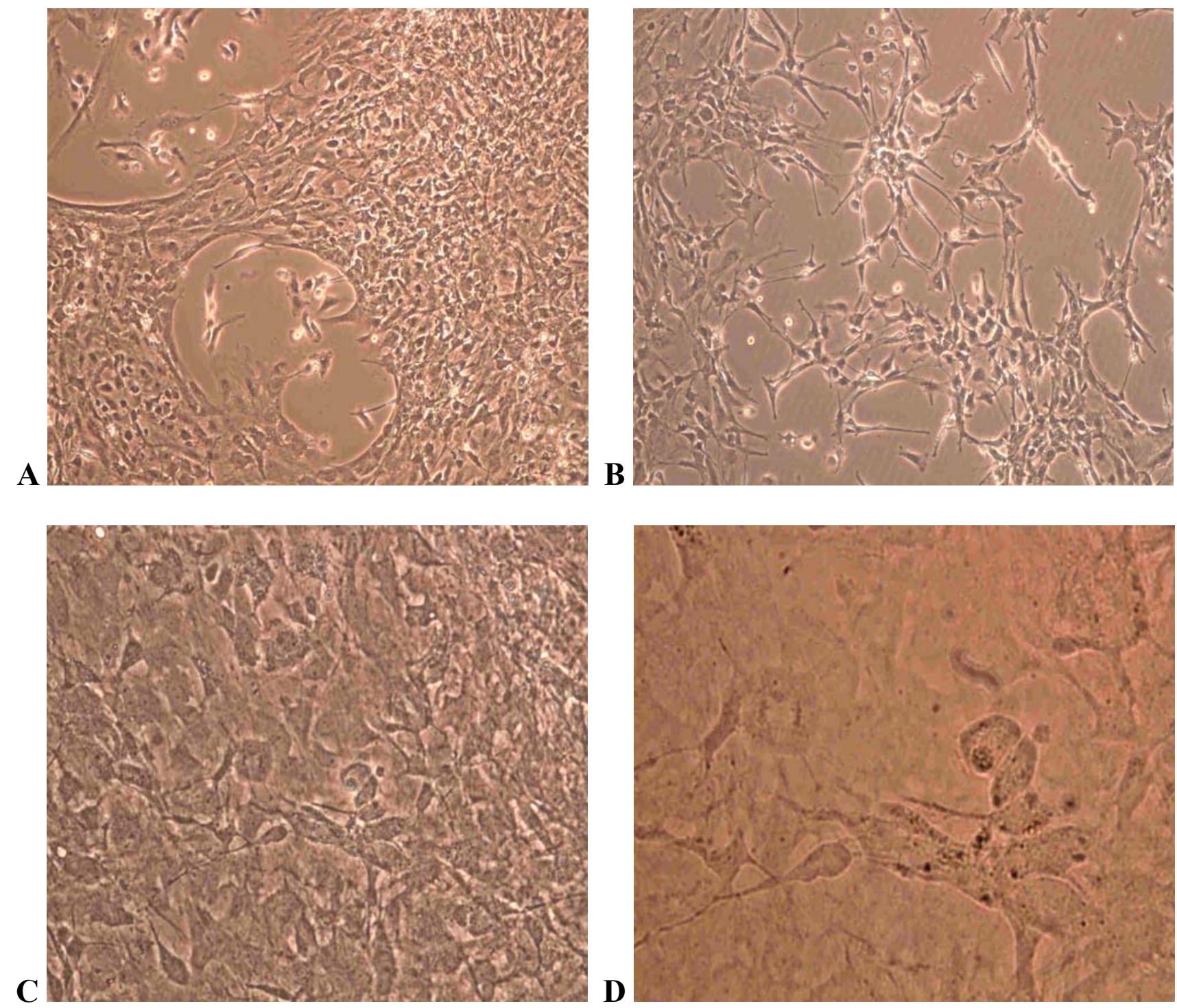

Fig. 35 Aspecte de microscopie optică ale culturii de 9 zile tratată cu apã MARIA 25\%

(A- mărire x10 - insulã de celule, B- mărire x10, C- mărire x30, D- mărire x40)

Tratamentul numărul 2 cu apă minerală Maria 25\% administrat în ziua a noua conduce la apariția unor goluri în monostratul celular, ca urmare a resorbției unor celule gliale din structura acestuia (fig. 35 A). Diviziunile celulare sunt frecvente şi uşor de identificat la analiza microscopicã a culturii (fig. $35 \mathrm{C}, \mathrm{D}$ ). Cultura atinge un nivel maxim de preconfluențã a monostratului de celule gliale (fig. 35 A-D). 


\section{M25-ziua 11}
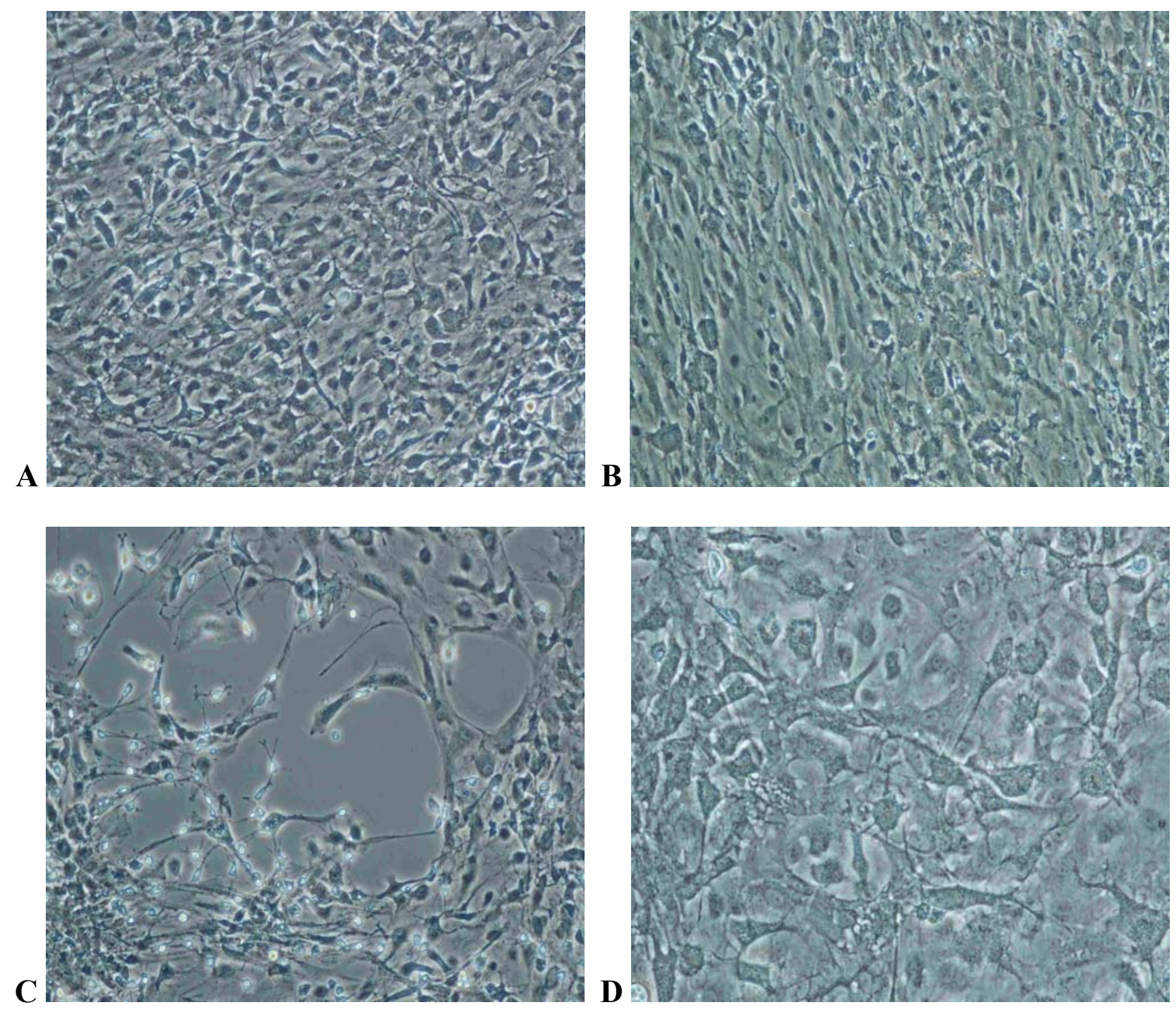

Fig. 36 Aspect de microscopie optică al culturii de 11 zile tratată cu apã MARIA 25\%

(A- mărire x15, B- mărire x15, C- mărire x15, D- mărire x40)

În ziua a 11-a a culturii de celule gliale tratatã cu apă minerală Maria $25 \%$ se constatã confluența monostratului celular (fig. 36 A-B). Celulele prezintă prelungiri celulare mult mai lungi şi mai groase ce mențin celulele aderate la substrat (fig. $36 \mathrm{C}$ ). Sunt înregistrate diviziuni celulare numeroase şi aspectul celulelor poate fi considerat normal. Heterogenitatea culturii, rezultatã din prezența astrocitelor de tip I şi II, oligodentrocitelor şi microgliilor, toate în variante imature sau mature, este o caracteristicã generalã a culturii de celule gliale, prezentã însã şi în cazul martor. 


\section{M25-ziua 12}
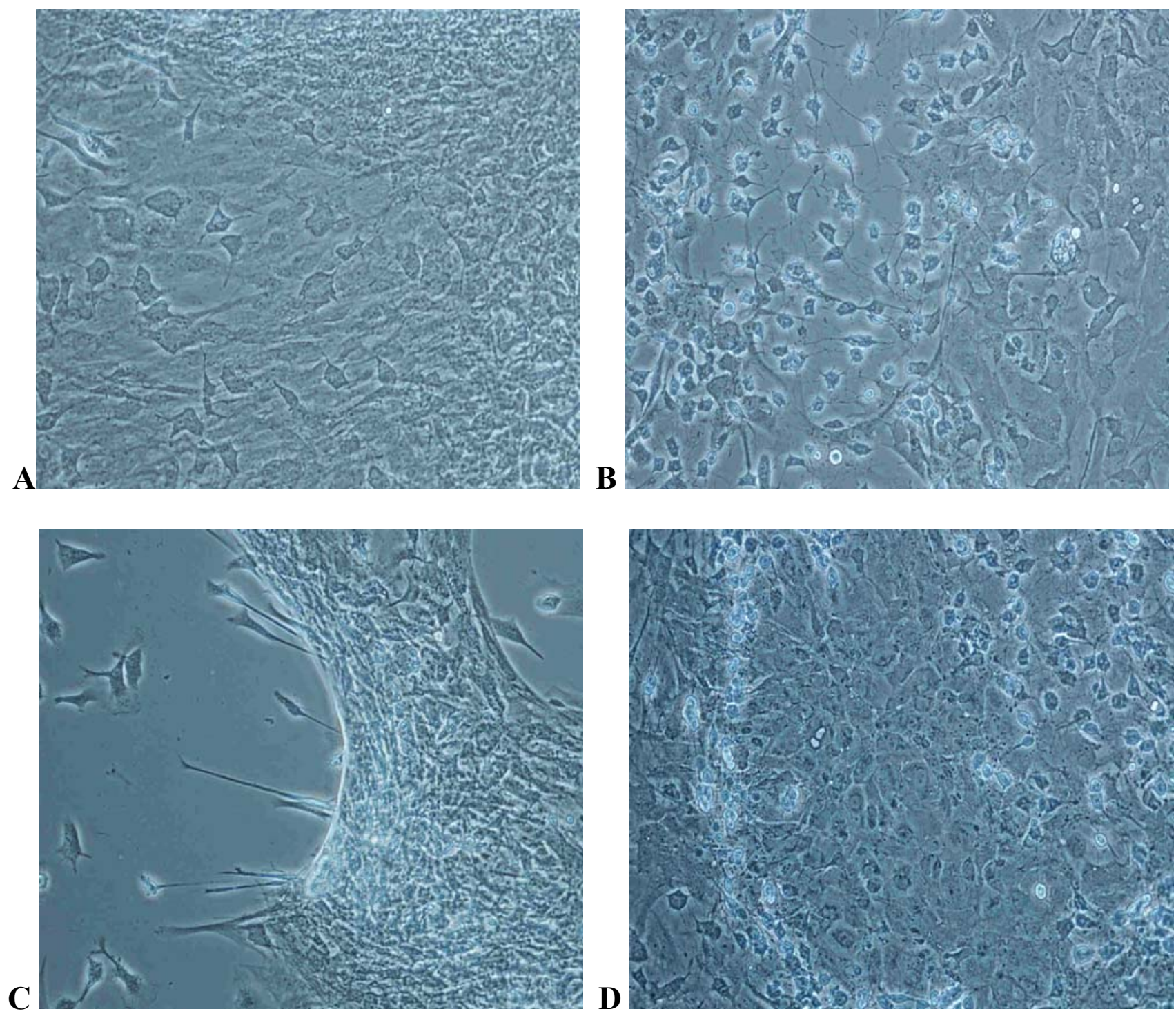

Fig. 37 Aspect de microscopie optică al culturii de 12 zile tratată cu apã MARIA 25\% (A- mărire x20, B- mărire x20, C- mărire x10, D- mărire x15)

Tratamentul numărul 4 cu apă minerală Maria 25\% administrat în ziua a 12 -a duce la plierea monostratului celular (fig. 37 C). Plierea este de joasă intensitate. Nu se formează suluri. Se observă faptul că adeziunea la substrat a celulelor este mult mai puternică. De asemnea celulele prezintă prelungiri celulare mult mai lungi şi mai groase care mențin celulele aderate la substrat (fig. 37 C). Sunt înregistrate diviziuni celulare numeroase şi aspectul celulelor poate fi considerat normal. După 12 zile de cultivare, celule gliale tratate cu apă minerală Maria $25 \%$ se prezintă într-o formă foarte asemănătoare cazului martor. 


\section{M25-ziua 14}
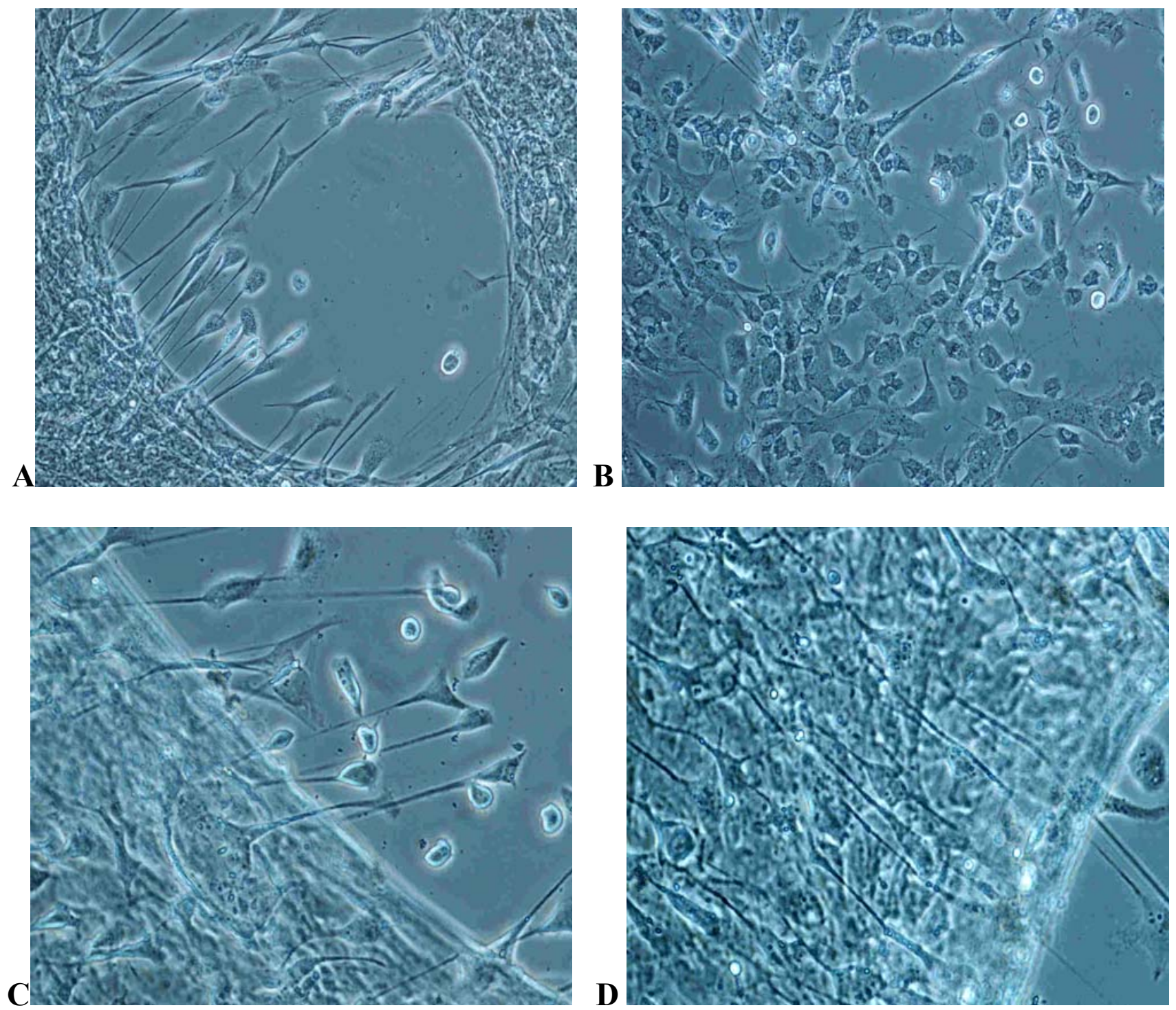

Fig. 38 Aspect de microscopie optică al culturii de 14 zile tratată cu apã MARIA 25\%

(A- mărire x30, B- mărire x30, C- mărire x30, D- mărire x40)

În ziua a 14-a a culturii de celule gliale tratatã cu apã Maria $25 \%$ se remarcã atingerea unui nivel avansat de maturizare celularã, caracterizat prin diferențierea celularã pronunţatã. Astfel, în figura $38 \mathrm{~A}, \mathrm{C}$ şi D se observã prezența unor celule gliale cu prelungiri lungi, aflate în zone speciale, formate de golurile din monostrat, cu aceeaşi direcție, care sinapseazã cu celule gliale aflate în monostratul de celule gliale. Hetrogenitatea culturii de celule gliale, analizatã în microscopie opticã, relevã caracterul complex al acestei însuşiri, prin care se mimeazã structuri tisulare existente la nivelul sistemului nervos central. 


\section{M25-ziua 15}
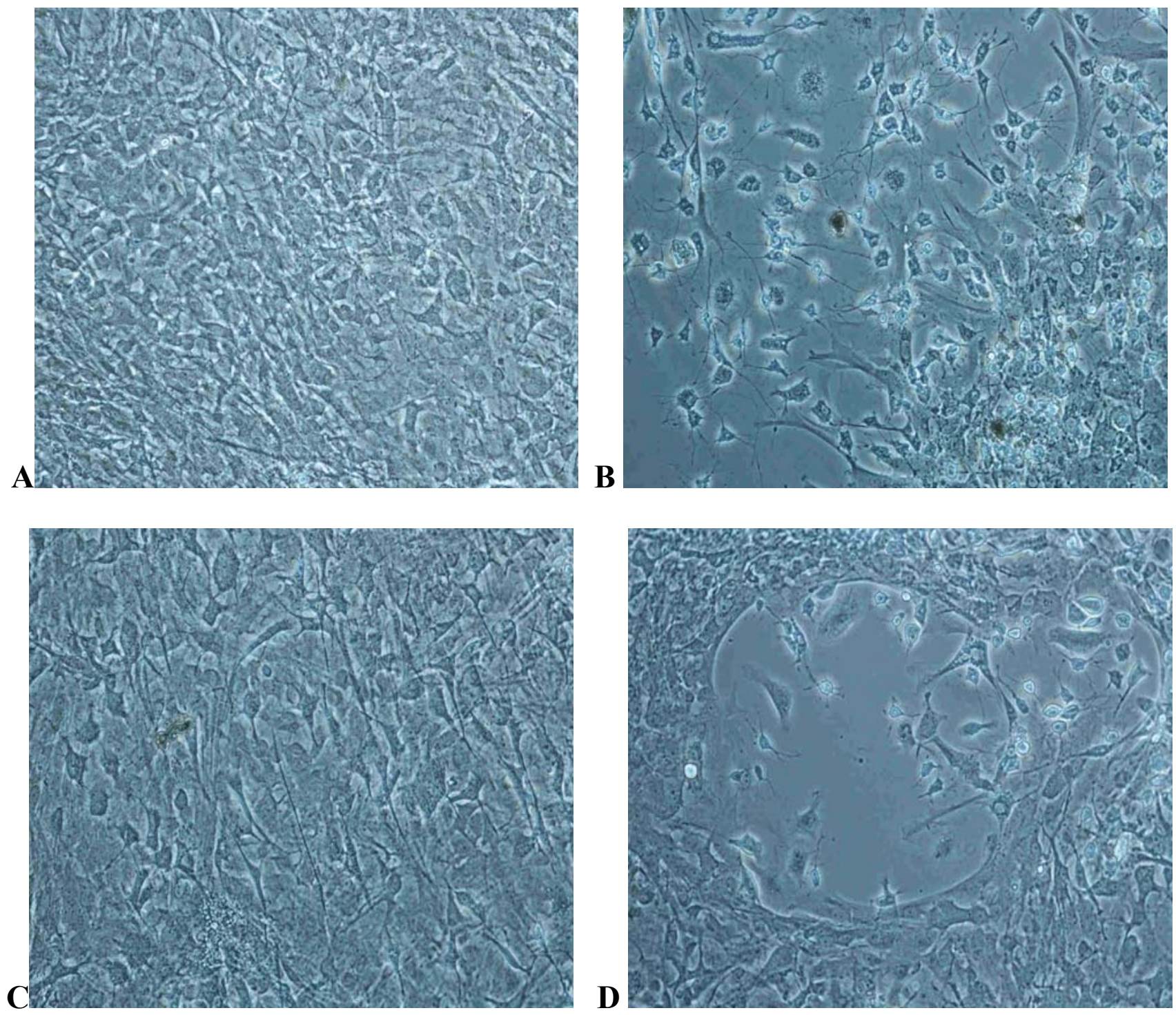

Fig. 39 Aspect de microscopie optică al culturii de 15 zile tratată cu apã MARIA 25\% (A- mărire x15, B- mărire x15, C- mărire x20, D- mărire x15)

După 15 zile de cultivare, celule gliale tratate cu apă minerală Maria 25\% se prezintă într-o formă foarte asemănătoare cazului martor. Prelungirile celulelor gliale sunt însă mai lungi şi mai groase iar interconexiunile dintre celule sunt mai uşor de observat. Apar şi fenomene de moarte celulară programată, iniţiate prin creşterea semnificativă în volum a unor celule şi pierderea prelungirilor celulare. La acest moment are loc stoparea creşterii, prelevarea mediului de culturã pentru analize biochimice şi pregãtirea culturii pentru obținerea omogenatului proteic total ce va reprezenta proba analizelor electroforetice şi pentru Western blotting. 


\section{M25 + Li 1 mM-ziua 7}
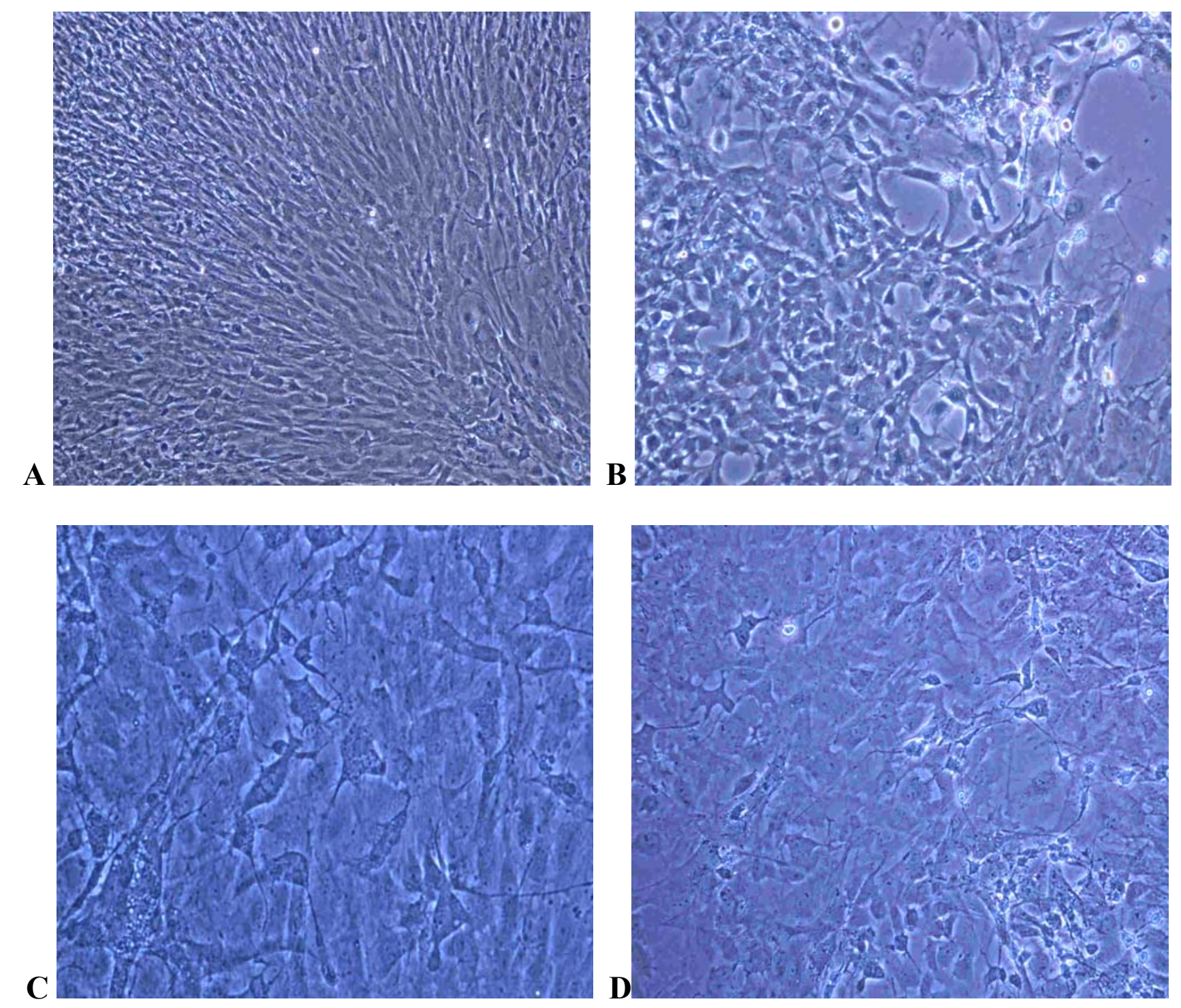

Fig. 40 Aspect de microscopie optică al culturii de 7 zile tratată cu apã MARIA 25\% şi 1mM LiCl

(A- mărire x10, B- mărire x20, C- mărire x30, D- mărire x20)

În varianta experimentală a tratării culturii de celule gliale cu apă minerală Maria şi cu $1 \mathrm{mM} \mathrm{LiCl}$, culturile au un aspect normal, existând o micã proporție de celule hipertrofiate, neobservate în culturile martor şi în cele cu ape minerale litinifere. Frecvența mare a diviziunilor celulare are drept consecință vizibilă microscopic o multistratificare a culturii (Fig. 40 C şi D). Rata de multiplicare înaltă este însoțită şi de o resorbție celulară intensă, care are rolul de a structura rapid insulele celulare. Apariţia vacuolizărilor citoplasmatice indică totuşi atingerea unui nivel toxic de către litiu. 


\section{M25 + Li 1 mM-ziua 9}
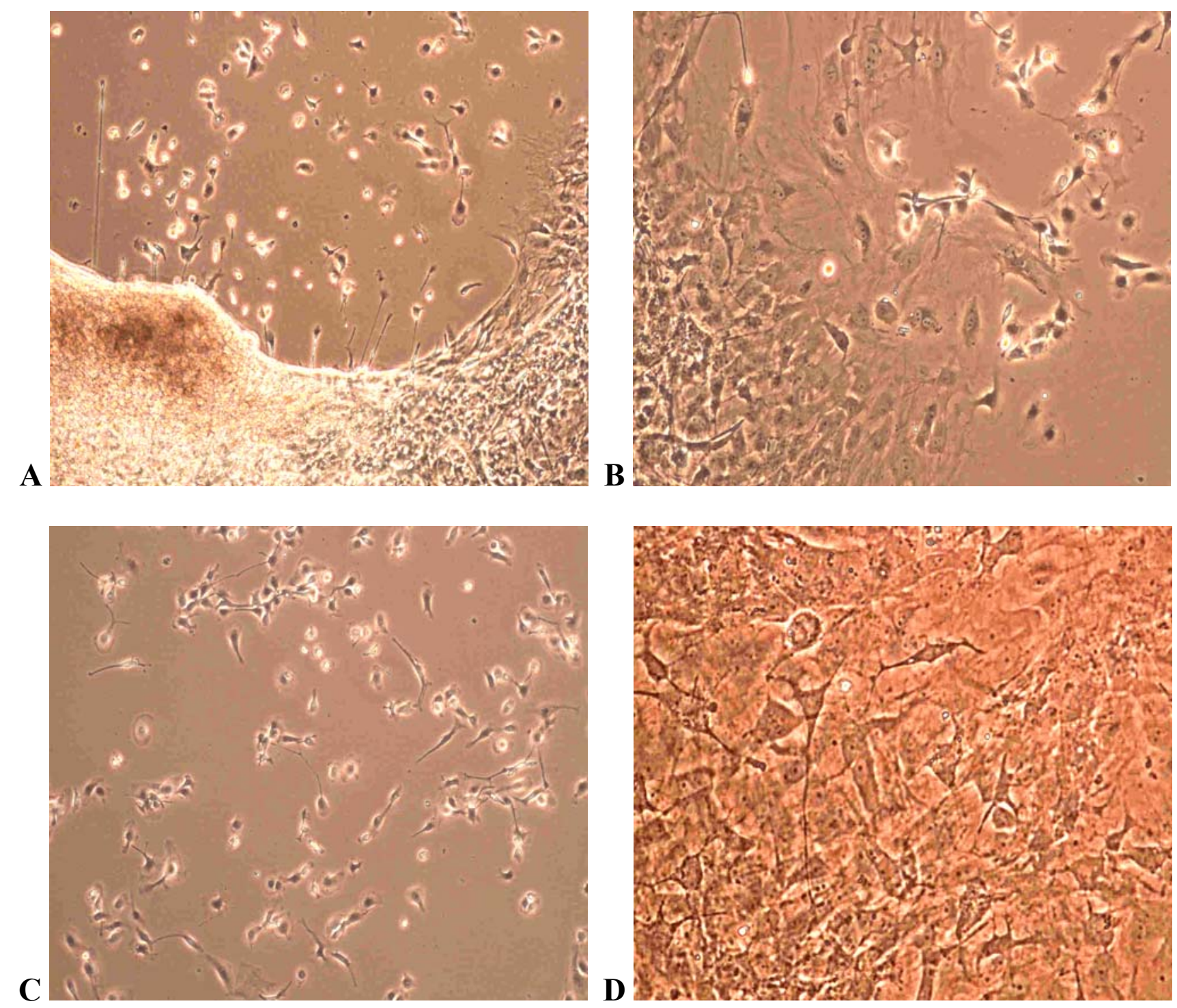

Fig. 41 Aspect de microscopie optică al culturii de 9 zile tratată cu apã MARIA 25\% şi 1mM LiCl (A- mărire x10, B- mărire x20, C- mărire x10, D- mărire x30)

În ziua a 9-a, la o zi după tratamentul numărul 2 cu apă minerală Maria 25\% + Li $1 \mathrm{mM}$, se observă desprinderea perifericã a monostratului de celule al culturii, aşa cum se poate vedea în figura $56 \mathrm{~A}$. Celule gliale desprinse din monostrat dupã pierderea parţialã perifericã a adeziunii la substratul de cultivare, se reataşeazã la substrat şi încep o existențã individualã, dupã cum de poate observa în figura 41 C. Multiplicările celulare apar cu frecvență mare, observându-se microscopic celule în diferite etape ale fazei mitotice. Apar zone în care predominã procesele necrotice (fig. $41 \mathrm{~B}$ ), dar şi zone în care aspectul este identic cu o zonã similarã din cazul martor (Fig. 41 D). 


\section{M25 + Li 1 mM-ziua 10}
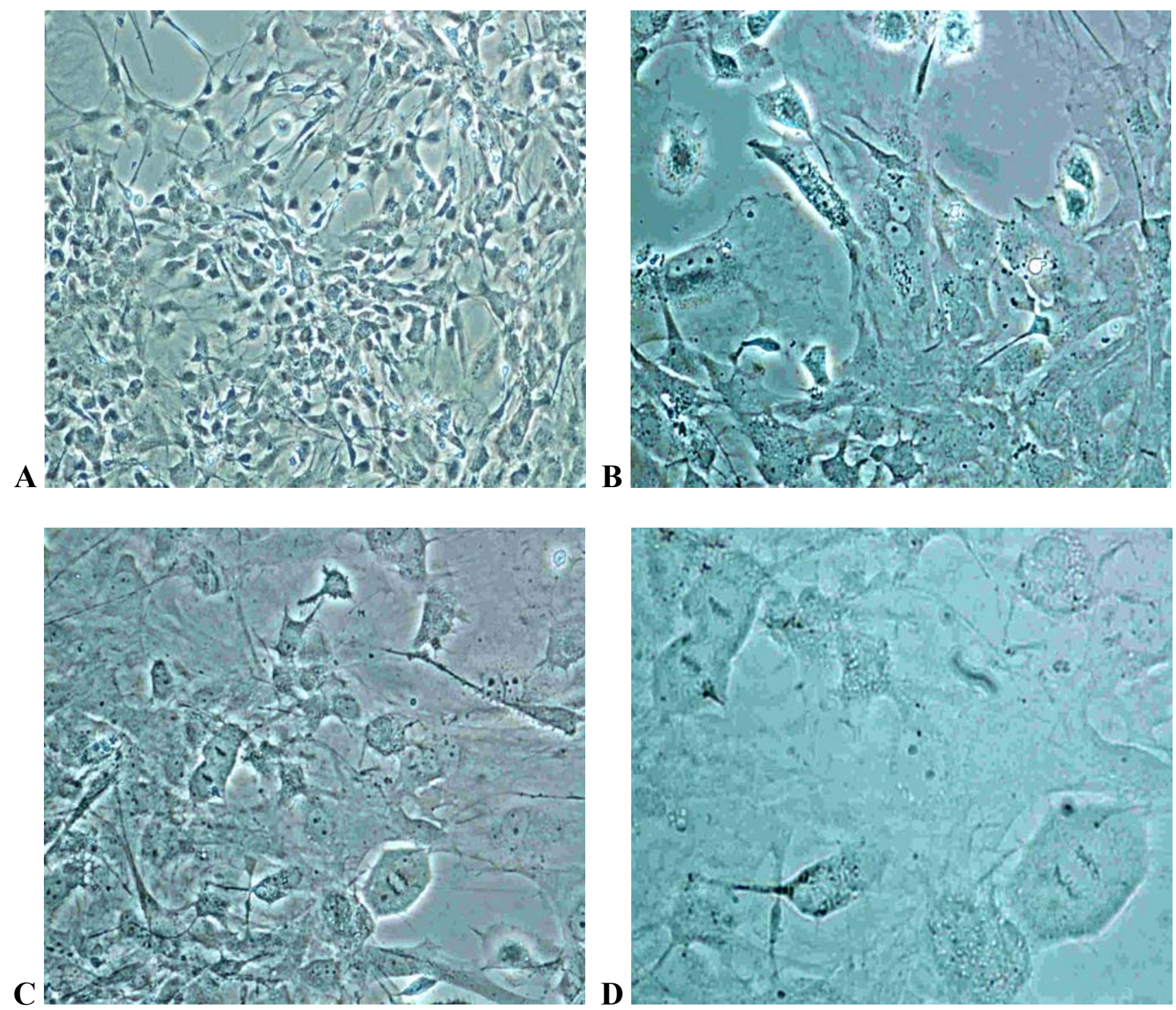

Fig. 42 Aspect de microscopie optică al culturii de 10 zile tratată cu apã MARIA 25\% şi 1mM LiCl (A- mărire x15, B- mărire x30, C- mărire x40, D- mărire x60)

Tratamentul numărul 3 cu apă minerală Maria $25 \%$ şi Li $1 \mathrm{mM}$, administrat în ziua a 10-a, duce la creşterea frecvenței multiplicãrilor celulare (fig. 42 C-D). Se observă faptul că adeziunea la substrat a celulelor este mult mai puternică. De asemnea celulele prezintă prelungiri celulare mult mai lungi şi mai groase care mențin celulele aderate la substrat. Apar zone în care fenomenul necrotic este preponderent (fig. 42 B), ceea ce demonstreazã faptul cã sunt accelerate în egalã mãsurã procesele mitotice dar şi cele necrotice la nivelul acestui caz. 


\section{M25 + Li 1 mM-ziua 12}
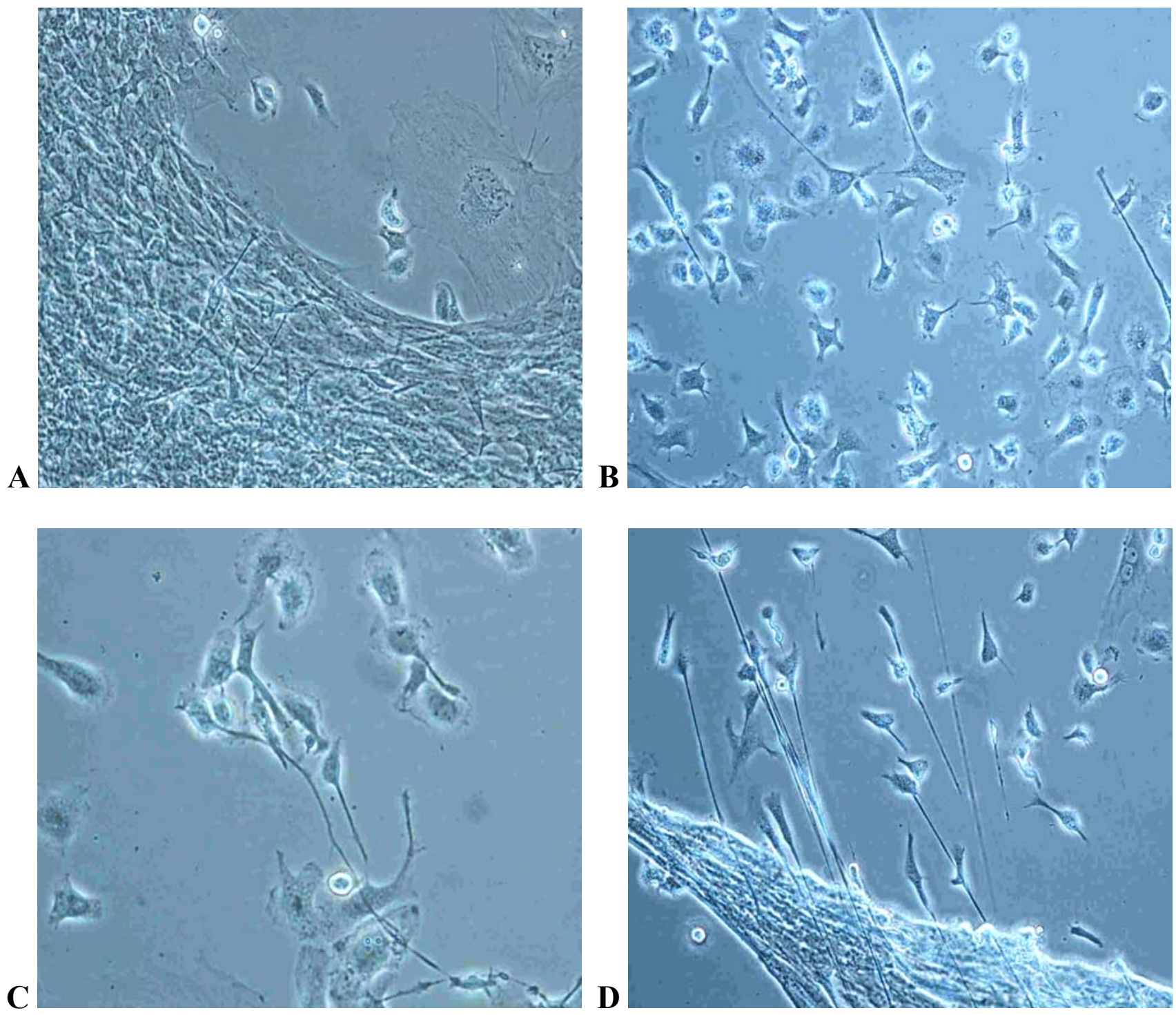

Fig. 43 Aspect de microscopie optică al culturii de 12 zile tratată cu apã MARIA 25\% şi 1mM LiCl (A- mărire x15, B- mărire x20, C- mărire x30, D- mărire x30)

După 12 zile de cultivare, celule gliale tratate cu apă minerală Maria $25 \%$ şi Li $1 \mathrm{mM}$ se prezintă într-o formă avansatã de maturare (fig. 43 A-D). Apar frecvent fenomene de necrozã şi moarte celulară programată, iniţiate prin creşterea semnificativă în volum a unor celule şi pierderea prelungirilor celulare (fig. 43 A-C). Prelungirile celulelor gliale sunt mai lungi şi mai groase, iar interconexiunile dintre celule sunt mai uşor de observat (fig. 59 C-D). În aceastã zi se aplicã tratamentul numãrul 4 cu apã mineralã Maria 25\% + Li 1mM. 


\section{M25 + Li 1 mM-ziua 14}
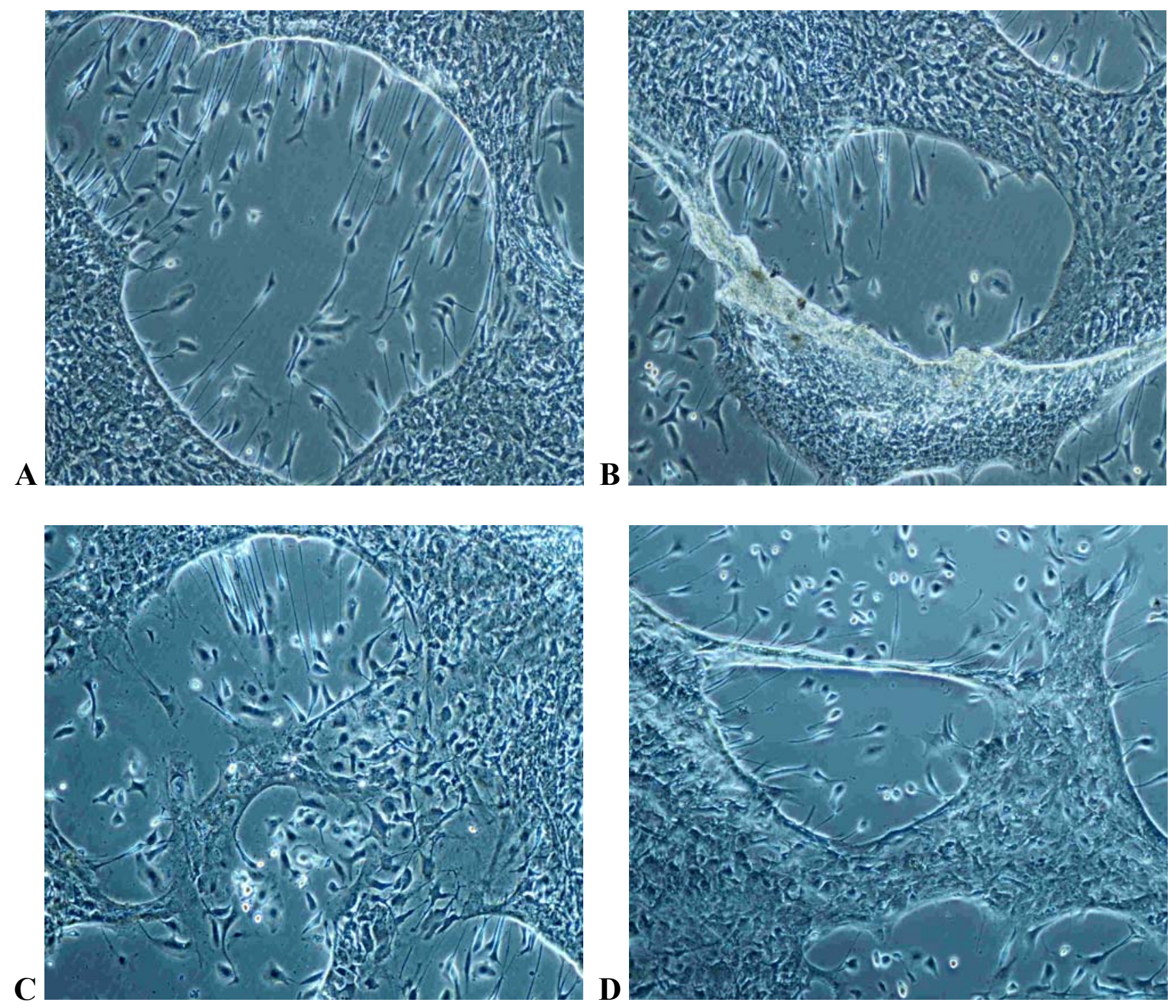

Fig. 44 Aspect de microscopie optică al culturii de 14 zile tratată cu apã MARIA 25\% şi 1mM LiCl

(A- mărire x 10, B- mărire x 10, C- mărire x10, D- mărire x10)

După 14 zile de cultivare, celule gliale tratate cu apă minerală Maria 25\% şi Li $1 \mathrm{mM}$ tratate a cincea oarã cu mediul corespunzãtor, se prezintă într-o formă pronunțatã de maturare şi diferențiere celularã (fig. 44 A-D). Apar numeroase procese necrotice şi de moarte celulară programată. Se observã creşterea individualã a unor celule gliale desprinse din monostrat. Golurile din monostrat şi plierile foiţiei celulare, dupã pierderea parţialã a adeziunii la substrat sunt prezente cu o frecvențã mai mare decât la oricare alt caz. Prelungirile unor celule gliale sunt lungi şi groase, iar interconexiunile dintre celule mai puternice, existând celule care deşi aflate în afara monostratului se conexeazã sinaptic cu celule din acesta, dând aspectul unor piloni de susținere (fig. 44 A-D). 


\section{M25 + Li 1 mM-ziua 15}
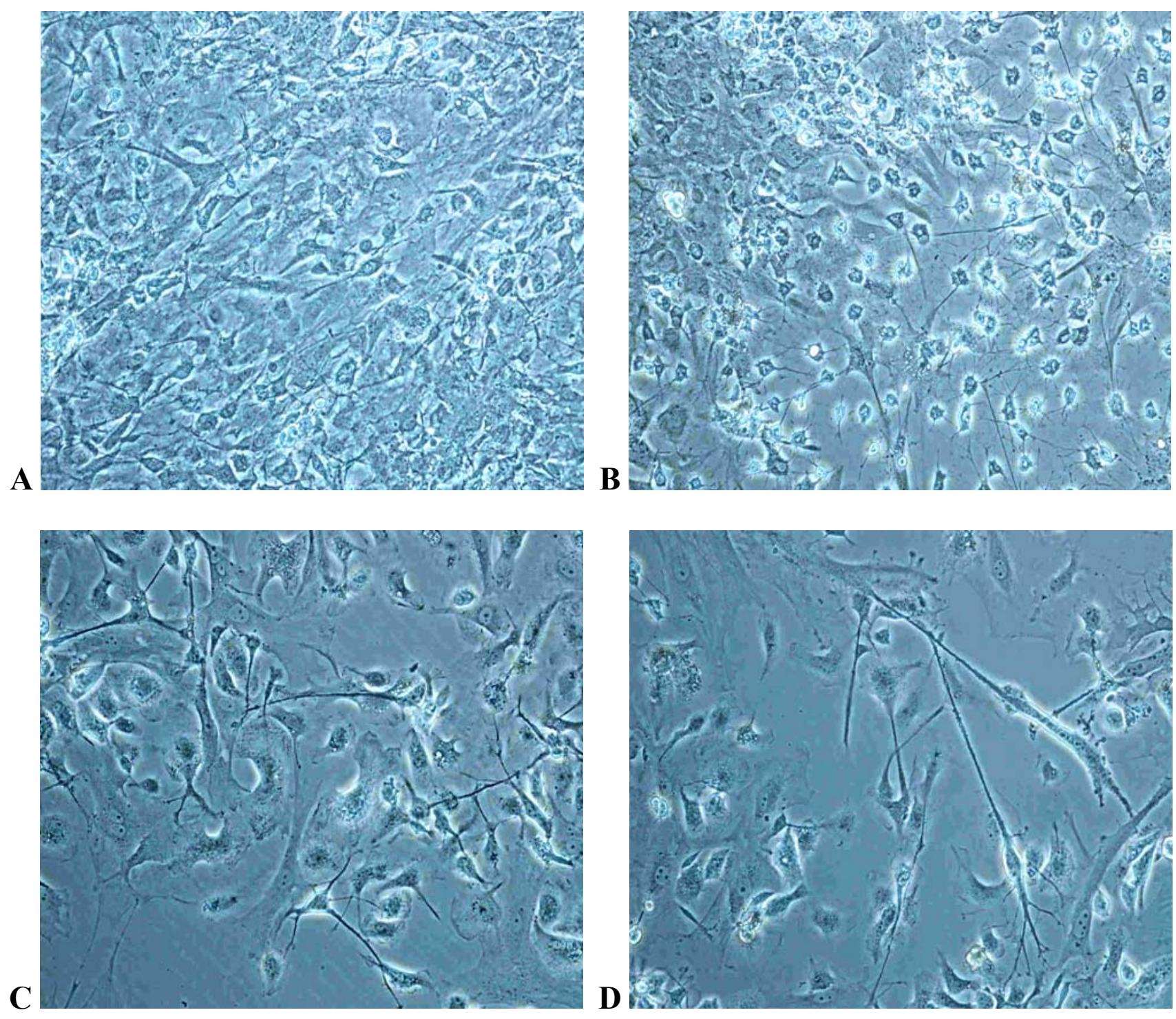

Fig. 45 Aspect de microscopie optică al culturii de 15 zile tratată cu apã MARIA 25\% şi 1mM LiCl (A- mărire x20, B- mărire x20, C- mărire x20, D- mărire x20)

După 15 zile de cultivare, celule gliale tratate cu apă minerală Maria 25\% şi Li $1 \mathrm{mM}$ se prezintă într-o formă maturã (fig. 45 A-D). Se remarcã prelungirile mai lungi şi mai groase ale unor celule gliale (fig $45 \mathrm{C}$-D). Apar frecvent procese de necrozã şi de moarte celulară programată (fig $45 \mathrm{C}$-D). La acest moment are loc stoparea creşterii, prelevarea mediului de culturã pentru analize biochimice şi pregãtirea culturii pentru obţinerea omogenatului proteic total ce va reprezenta proba analizelor electroforetice şi pentru Western Blotting. 


\section{Concluzii}

Având în vedere buletinul de analize al apei minerale Maria de la Malnaş-Bãi, observãm cã nivelul litiului de $8,03 \mathrm{mg}$ la litru şi concentrația celorlați ioni permit caracterizarea apei minerale MARIA ca fiind o apã mineralã litiniferã, bicarbonatatã, cloruratã, sodicã, carbogazoasã, hipotonã.

Prezența substanțelor minerale cu proprietãțile fizico-chimice determinate, rãspund necesitãților profilactice de ameliorare a stãrii de sãnãtate a pacienților maniaco-depresivi deoarece:

1. Nivelul litiului din apa mineralã MARIA fiind de $8,03 \mathrm{mg}$ la litru, corespunde unui nivel seric atins prin consumul zilnic a unui litru de apã de $0,25 \mathrm{mM}$. Acest nivel este la limita inferioară a intervalului terapeutic, şi de 10 ori mai mic decât nivelul toxic de $2 \mathrm{mM}$, asigurând siguranța consumului apei;

2. Studiul morfologiei celulelor gliale demonstreazã cã un consum zilnic de apã de până la un litru, corespunzãtor cazului de tratament cu $25 \%$ al culturilor de celule gliale, are efecte pozitive asupra celulelor, îmbunãtãțind comunicarea intercelularã şi crescând nivelul interconexiunilor;

3. Rata de diviziune a celulelor gliale tratate cu $25 \%$ apa mineralã Maria creşte seminificativ fațã de martor, fapt evidențat de compararea profilurilor electroforetice pentru cele douã cazuri. Acest argument suștine caracteristica sãrurilor de litiu ( $\mathrm{LiCl} 1 \mathrm{mM})$ de a induce o creştere a numãrului de celule gliale.

4. Rezultatele experimentale ce susțin creșterea numãrului de celule gliale, cu morfologie normalã, reprezintã un argument terapeutic major, ştiind din literatura de specialitate faptul cã în maniaco-depresie are loc o pierdere de celule gliale (Berns and Nemeroff, 2003);

5. Testele biochimice efectuate aratã cã parametrii biochimici ai mediului de cultivare al celulelor sunt apropiați în cazul tratamentului cu apã Maria $25 \%$ de cei determinați la martor;

6. Profilul electroforetic al omogenatului celular al culturii, tratatã cu $25 \%$ apã mineralã Maria, are un grad foarte mare de potrivire cu profilul obținut în cazul tratamentului cu Li 1 mM şi în cazul martor;

7. Detecția imunohistochimicã a lamininei şi vimentinei nu aratã diferențe semnificative ale distribuției lor celulare la martor, Maria 25 \% şi Li 1 mM;

8. Detecția prin Western blotting a proteinelor GFAP, GSK-3 $\beta$ şi SHIP2 subliniazã caracterul terapeutic al apei minerale MARIA prin concordanța rezultatelor obținute la cazurile Maria 25\% şi Li 1 mM, fațã de martor. 
Nivelul de $50 \%$ apã mineralã MARIA este similar în efecte cu cazul tratamentului cu Li $2 \mathrm{mM}$. Similaritatea efectelor este generatã de impactul ionilor de litiu în coroborare cu efectele celorlalte elemente chimice prezente. Toxicitatea concentrației de $2 \mathrm{mM} \mathrm{LiCl}$, asemãnãtoare unui nivel de $50 \%$ apã mineralã Maria se caracterizeazã prin:

1. Celulele devin rotunde, hipertrofiate, citoplasma se vacuolizeazã;

2. Se produce o scãdere a numãrului de prelungiri celulare;

3. Apar fenomene de lizã celularã care determinã apariția de „ochiuri” în monostrat iar aspectul general al culturii este de rețea laxã;

4. Se modificã substanţial profilul electroforetic al omogenatului celular;

5. Testele biochimice aratã modificãri semnificative a mai multor parametri bichimici analizați fațã de cazul martor.

Soluția salină ce mimeazã conţinutul de $\mathrm{Na}^{+}, \mathrm{K}^{+}, \mathrm{Ca}^{2+}$ şi $\mathrm{Mg}^{2+}$ din apa mineralã Maria, are efecte pozitive asupra celulelor gliale, rezultatele experimentale arãtând cã tratarea celulelor gliale in vitro cu preparatul MARIASOL:

1. Creşte rata de diviziune şi diferențiere celularã a celulelor gliale;

2. Profilul electroforetic este asemãnãtor cu al martorului;

3. Testele biochimice se coreleazã cu rezultatele din cazul martor;

4. Nivelul proteinelor analizate prin imunodetecție şi Western blotting sugereazã expresii similare ale acestora în cazul tratãrii celulelor gliale cu preparatul MARIASOL, fațã de cazul martor.

Sinteza rezultatelor experimentale duce la concluzia generalã cã apa mineralã litiniferã MARIA de la Malnaş-Bãi, Județul Covasna, conține substanțe minerale care ĩi conferã proprietãți terapeutice şi care justificã valoarea sa medicalã, fãrã sã existe pericole pentru sãnãtatea umanã, fapt demonstrat de capacitatea apei de a menține viața celulelor gliale cultivate în laborator.

Singura atenționare trebuie fãcutã în legãturã cu salinitatea ridicatã a apei, de $5,8 \mathrm{~g}$ la litru, ceea ce necesitã integritatea funcţiei renale şi un nivel optim al filtrãrii glomerulare. 


\section{Bibliografie}

1. Adams. F. The Extant Works of Aretaeus the Cappadocian. Sydenham Society, 1856.

2. Akiskal H.S. - The Scope of Bipolar Disorders, Bipolar Psychopharmacotherapy: Caring for the Patient, Edited by Askiskal H.S. and Tohen M., 2006;

3. Akiskal H.S., Mallya G. Criteria for the soft bipolar spectrum: treatment implications. Psychopharmacol. Bull., 1987.

4. Alarcon R., Fuenzalida C., Santibanez M., Bernhardi R. - Expression of Scavenger Receptors in Glial Cells, The Journal of Biological Chemistry, Vol. 280, Nr. 34, p. 30406-30415, 2005;

5. Alberts B., Bray D., Lewis J., Raff M., Roberts K., Watson J.D. (1994) Molecular biology of the cell, IIIrd ed. Garland Publ. New York and London.

6. Alosi F., Agresti C., Levi G. - Establishment, Characterization, and Evolution of Cultures Enriched in Type-2 Astrocytes, Journal of Neuroscience Research, Vol. 21: 188-198, 1988;

7. Amédéé T., Robert A., Coles J.A.- Potassium Homeostasis and Glial Energy Metabolism, GLIA, Vol. 2, p 46-55, 1997;

8. Angst J. - Do Many Patients with Depression Suffer From Bipolar Disorder?, Canadian Journal of Psychiatry, Vol. 51, No. 1, p: 3-5, 2006;

9. Angst Jules - The Bipolar Spectrum, British Journal of Psychiatry, Vol.190, 189-191, 2007;

10. Ani M., Moshtaghie A.A., Akbarzadeh S., - Changes in Biochemical Parameters Related to Lipid Metabolism Following Lithium Treatment in Rat, Iranian Biomedical Journal 9 (1): 27-32, 2005;

11. Araque A., Li N, Doyle R.T., Haydon P. G. - SNARE Protein- Dependent Glutamate Release from Astrocytes, The Journal of Neuroscience, Vol. 20 (2), p.: 666-673, 2000;

12. Arenander A.T., De Vellis J. (1994) Development of the nervous system. In: Basic neurochemistry: Molecular, cellular and medical aspects, 5th ed. Ed. by Siegel G.J. et al., Raven press, New York: 573-606.

13. Aschner M. (1998) Immune and inflammatory responses in the CNS: Modulation by astrocytes. Toxicol. Lett. 102-103: 283-287.

14. Aschner M., Allen J.W., Kimelberg H.K., LoPachin R.M., Streit W.J. (1999) Glial cells in neurotoxicity development. Ann. Rev. Pharmacol. Toxicol. 39: 151-173.

15. Aschner M., Bennett A. (1997) Astrocyte and neuron coculturing method. In: Methods in molecular medicine, vol. 22 Ed. by Harry J., Tilson H.A. Humana press Inc. Totowa New York: 13-144.

16. Aschner M., Vitarella D. (1995) Central nervous system glial cell cultures for neurotoxicological investigations. In: Neurotoxicology: Approaches and methods. Academic Press: 549-562.

17. Austin M.P., Mitchell P.B. (1998) Psichotropic medications in pregnant women: treatment dilemmas. MJA 169, 428-431;

18. Avissar S., Schreiber G., Danon A., Belmaker R.H. - Lithium inhibits adrenergic and cholinergic increases in GTP binding in rat cortex, NATURE, Vol. 331, p.440-442, 1998;

19. Badiu Gh., Teodorescu-Exarcu I. (1978) Fiziologia şi fiziopatologia sistemului nervos. Ed. Medicală Bucureşti: 79-177.

20. Baillarger J. De la folie a double forme. Ann. Med. Psychol., Paris, 1854.

21. Barres Ben A. - A New Role for Glia: Generation of Neurons, Cell, Vol. 97, 667-670, 1999;

22. Basselin M., Chang L., Seemann R., Bell J.M. and Rapoport S.I. - Chronic Lithium Administration to Rats Selectively Modifies 5- $\mathrm{HT}_{2 \mathrm{~A} / 2 \mathrm{C}}$ Receptor-Mediated Brain Signaling via Arachidonic Acid, Neuropsychopharmacology, Vol. 30, 461-472, 2005;

23. Beal M.F. (1995) Aging, energy and oxidative stress in neurodegenerative diseases. Ann. Neurol. 38: 357-366. 
24. Belmaker R.H., Agam G., van Calker D., Richards M.H., Kofman O. (1998) Behavioral reversal of lithium effects by four inositol isomers correlates perfectly with biochemical effects on the PI cycle: Depletion by chronic lithium of brain inositol is specific to hypothalamus and inositol levels may be abnormal in postmortem brain from bipolar patients. Neuropsychopharmacology 19: $220-232$.

25. Berns G.S and Nemeroff C.B. - The Neurobiology of Bipolar Disorder, American Journal of Medical Genetics Part C, vol. 123C, 76-84, 2003;

26. Berridge M.J., Downes C.P., Hanley M.R. (1989) Neural and developmental actions of lithium: A unifying hypothesis. Cell 59: 411-419.

27. Bhat N.R. (1995) Signal transduction mechanisms in glial cells. Dev. Neurosci. 17: 267-284.

28. Bhatnagar R.K., Antidepressants and Affective Disorders, 71:130, 160-168, 2005;

29. Bijur G.N., De Sarno P., Jope R.S. - Glycogen Synthase Kinase -3 $\beta$ Facilitates Staurosporine and Heat Shock-induced Apoptosis, The Journal of Biological Chemistry, Vol. 275, Nr. 11, 75837590, 2000;

30. Birch N.J. (1999) Inorganic pharmacology of lithium. Chem. Rev. 99: 2659-2682.

31. Borlongan C.V., Yamamato M., Takei N., Kumazaki M., Ungsuparkorn C., Hida H., Sanberg P.R., Nishino H. - Glial cell survival is enhanced during melatonin-induced neuroprotection against cerebral ischemia, The FASEB Journal, Vol. 14, 1307-1317, 2000;

32. Brismar Tom - Physiology of Transformed Glial Cells, GLIA 15: 231-243, 1995;

33. Brüstle O., Jones K.N., Learish R.D., Karram K., Choudhary K., Wiestler O.D., Duncan I.D., McKay R.D.G. - Embryonic Stem Cell - Derived Glial Precursors: A Source of Myelinating Transplants, SCIENCE, Vol. 285, 754-756, 1999;

34. Brzyska M., Stege G.J.J., Renkawek K., Bosman G.J.C.G.M. - Heat shock, but not the reactive state per se, induces increased expression of the small stress proteins hsp25 and $\alpha \mathrm{B}$-crystallin in glial cells in vitro, NeuroReport, Vol. 9, Nr.7, 1549-1552, 1998;

35. Burstein D.E., Seeley P.J. and Greene L.A. (1985)- Lithium ion inhibits Nerve Growth Factor induced neurite outgrowth and Phosphorylation of Nerve Growth Factor -modulated Microtubule-associated Proteins, The Journal of Cell Biology. Vol 101, 962-870,

36. Calegari F., Coco S., Taverna E., Bassetti M., Verderio C., Corradi N., Matteoli M., Rosa P. - A Regulated Secretory Pathway in Cultured Hippocampal Astrocytes, The Journal of Biological Chemistry, Vol. 274, Nr. 32, 22539-22547, 1999;

37. Cameron R.S., Rakic P. (1991) Glial cell lineage in the cerebral cortex: A review and synthesis. Glia 4: 124-137.

38. Centeno F., Mora A., Fuetes J.M., Soler G., Claro E., (1998) Partial lithium associated protection against apoptosis induced by $\mathrm{C}_{2}$-ceramide in cerebellar granule neurons. NeuroReport 9, 41994203;

39. Chang C.M.J., Jones C.R. (1998) Chronic lithium treatment decreases brain phospholipase $\mathrm{A}_{2}$ activity. Neurochem. Res. 23: 887-892.

40. Chang J.C., Brewer G.J., Wheeler B.C. - Neuronal network structuring induces greater neuronal activity through enhanced astroglial development, Journal of Neural Engineering, Vol. 3, 217 226, 2006;

41. Chang K., Adleman N.E., Dienes K., Simenova D.I., Menon V., Reiss A. - Anomalous Prefrontal-Subcortical Activation in Familial Pediatric Bipolar Disorder- A Functional Magnetic Resonance Imaging Investigation, Arch Gen Psychiatry, Vol. 61, 781-792, 2004;

42. Charney D.S., Manji H.K. - Life Stress, Genes, and Depression: Multiple Pathways Lead to Increased Risk and New Opportunities for Intervention, SCIENCE'S STKE, re5, 2004;

43. Chen G., Yuan P.X., Huang L.D., Manji H.K. (1998) Lithium increases tyrosine hydroxylase levels both in vivo and in vitro. J.Neurochem. 70: 1768-1771. 
44. Chen G., Zeng W., Yuan P., Huang L., Jiang Y., Zhao Z., Manji H.K.- The Mood-Stabilizing Agents Lithium and Valproate Robustly Increase the Levels of the Neuroprotective Protein bcl-2 in the CNS, J. of Neurochemistry, Vol. 72(2), 879-882, 1999;

45. Chen Guang, Huang Li-Dong, Jiang Yi-Ming, Manji H.K. - The Mood-Stabilizing Agent Valproate Inhibits the Activity of Glycogen Synthase Kinase-3, Journal of Neurochemistry, Vol. 72, 1327-1330, 1999;

46. Chen Rui-Hong, Ding Vivianne W., McCormick F.- Wnt Signaling to $\beta$-Catenin Involves Two Interactive Components - Glycogen Synthase Kinase-3 $\beta$ inhibition and activation of protein kinase C, The Journal of Biological Chemistry, Vol. 275, Nr.23, 17894-17899, 2000;

47. Chesik D., Glazenburg K., Wilczac N., Geeraedts F., De Keyser J. - Insulin-like growth factor binding protein-1-6 expression in activated microglia, NeuroReport, Vol. 15(6), 2004;

48. Chirita V., Papari A., coordonatori Tratat de psihiatrie, Ed. Fundatiei "Andrei Saguna", Constanta, 2002.

49. Colin S.F., Chang H., Mollner S., Pfeuffer T., Reed R.R., Duman R.S., Nestler E.J. - Chronic lithium regulates the expression of adenylate cyclase and $\mathrm{G}_{\mathrm{i}}$-protein $\alpha$ subunit in rat cerebral cortex, Proc. Natl Acad. Sci. USA, Vol. 88, 10634-10637, 1991;

50. Commonly used tissue culture terms. (1990) In vitro cellular and development biology 26(1): 97100.

51. Corvalan V., Cole R., De Vellis J., Hagiwara S. - Neuronal modulation of calcium channel activity in cultured rat astrocytes, Proc. Natl Acad. Sci. USA, Vol. 87, 4345-4348, 1990;

52. Cotrutz C., Cotrutz C., Kocsis M., Ionescu C.R.(1994) Manual de lucrări practice de biologie celulară. Ed.Tehnică: 7-34.

53. Coyle J.T., Manji H.K. - Getting balance: Drugs for bipolar disorder share target, Nature Medicine, Vol. 8, Nr.6, 557-558, 2002;

54. Cruce, Mihai - Biologie celulară şi moleculară, Editura Aius, Craiova, 1999;

55. Cryns K., Shamir A., Shapiro J., Daneels G., Goris I., Van Craenendonck H., Straetemans R., Belmaker R.H., Agam G., Moechars D., Steckler T. - Lack of Lithium-Like Behavioral and Molecular Effects in IMPA2 Knockout Mice, Neuropsychopharmacology, 1-11, 2006;

56. D’Mello S.R., Anelli R., Calissano P., (1994) Lithium induces apoptosis in immature cerebellar granule cells but promotes survival of matue neurons. Experimental Cell Research 211, 332-338;

57. Daugherty D., Roque-Urrea T., Roque-Urrea J., Snyder J., Wirkus S., Porter M.A. Mathematical Models of Bipolar Disorder, 1-24, 2004;

58. Daugherty D., Urrea J., Roque T., Wirkus S. - Models of Negatively Damped Harmonic Oscillators: the Case of Bipolar Disorder, 1-24, 2002;

59. Dănăilă, Leon; Alecu, M; Coman, Gabriela - Apoptoza: moartea celulară programată, Editura Academiei Române, Bucureşti, 1999;

60. Del Rio E., Shinomura T., van der Kaay J., Nicholls D.G., Downes C.P. (1998) Disruption by lithium of phosphoinositide signalling in cerebellar granule cells in primary culture. $J$. Neurochem. 70: 1662-1669.

61. Detera-Waldeigh S.Lithium-related genetics of bipolar disorder. Ann. Med. 33, 2001

62. Diculescu I., Onicescu D. (1987) Histologie medicală, vol.I. Ed.Medicală Bucureşti.

63. Dilsaver S.C., Swann A.C., Shoaib A.M., Bowers T. - The Manic Syndrome: Factors Wihch May Predict a Patient's Response to Lithium, Carbamazepine and Valproate, Journal of Psychiatry and Neuroscience, Vol.18, Nr.2, 1993;

64. Dimitrova A., Milanova V., Krastev V., Nikolov I., Toncheva D., Owen M.J., Kirov G. Association study of myo-inositol monophosphatase 2 (IMPA2) polymorphisms with bipolar affective disorder and response to lithium treatment, The Pharmacogenomics Journal, Vol. 5, 35-41, 2005; 
65. Dixon J.F., Hokin L.E. (1997) The antibipolar drug valproate mimics lithium in stimulating glutamate release and inositol 1,4,5-trisphosphate accumulation in brain cortex and bisphosphates. Proc.Natl. Acad. Sci. USA 94: 4757-4760.

66. Dixon J.H., Los G.V., Hokin L. - Lithium stimulates glutamate „release” inositol 1,4,5trisphosphate accumulation via activation of the N-methyl-D-aspartate receptor in monkey and mouse cerebral cortex slices, Proc. Natl Acad. Sci. USA, Vol. 91, 8358-8362, 1994;

67. Dreher Z., Tout s., Stone J. (1994) Interactions of living astrocytes in vitro: Evidence of the development of contact spacing. Glia 11: 57-63.

68. Du J., Gray N.A., Falke C.A., Chen W., Yuan P., Szabo S.T, Einat H., Manji H.K. - Modulation of Synaptic Plasticity by Antimanic Agents: The Role of AMPA Glutamate Receptor Subunit 1 Synaptic Expression, The J. of Neuroscience, 24 (29), 6578-6589, 2004;

69. E. Chalecka-Franaszek and De-Maw Chuang, Lithium activates the serine/threonine kinase Akt-1 and suppresses glutamate-induced inhibition of Akt-1 activity in neurons, Proc. Natl Acad. Sci. USA, Vol. 96, 8745-8750, 1999,

70. Echrich B.E., Diamond J.M. (1979) Lithium fluxes in human erytrocytes. Amer. J. Physiol. 237: C102-C110.

71. Einat H., Kofman O., Itkin O., Lewutan R.J., Belmaker R.H. (1998) Augmentation of lithium's behavioral effect by inositol uptake inhibitors. J. Neural Transm. 105: 31-38.

72. Eliasson C., Sahlgren C., Berthold C.H., Stakeberg J., Celis J.E.,Betsholtz C., Eriksson J.E., Pekny M. (1999) Intermediate filament protein partnership in astrocytes. J. Biol. Chem. 274: 23996-24006.

73. Elyaman W., Yardin C., Hugon J. - Involvement of glycogen synthase kinase-3 $\beta$ and tau phosphorylation in neuronal Golgi disassembly, J. of Neurochemistry, 81, 870-880, 2002;

74. Eng L.F., Ghirnikar R.S. -GFAP and Astrogliosis, Brain Pathology, Vol.4, 229-237, 1994;

75. Eng L.F., Ghrinkar R.S., Lee Z.L. (2000) Glial fibrilllary acidic protein: GFAP- thirty one years . Neurochemical Research 25, 1439-1451;

76. $\quad$ Eng L.F., Lee Y.L. - Intermediate filaments in astrocytes, NEUROGLIA, 43, 650-667, 1995;

77. Esquirol J.E.D. Des maladies mentales, Paris, 1838.

78. Ewijk, W.; Brons, N.H.; Rozing, J. - Scanning electron microscopy of homing and recirculating lymphocyte population, Cell. Immunol., 19: 245-261, 1975;

79. Falret J.P. Memoire sur la folie circulaire. Bulletin de l'Academie de Medicine, 1854.

80. Fawcett J.W., Fersht N., Housden L., Schachner M., Pesheva P. - Axonal growth on astrocytes is not inhibited by oligodendrocytes, J. of Cell Science, Vol. 103, 571-579, 1992;

81. Feinstein D.L. - Potentiation of Astroglial Nitric Oxide Synthase Type-2 Expression by Lithium Chloride, Journal of Neurochemistry, Vol. 71, Nr.2, 883-886, 1998;

82. Ferkey D.M., Kimelman D. - GSK-3: New Thoughts on an Old Enzyme, Developmental Biology, Vol. 225, 471-479, 2000;

83. Fischer G., Kettenmann H. - Cultured Astrocytes Form a Syncytium after Maturation, Experimental Cell Research, Vol. 159, 273-279, 1985;

84. Flanagan L.A,., Rebaza L.M., Derzic S., Schwartz P.H., Monuki E.S. - Regulation of Human Precursor Cells by Laminin and Integrins, Journal of Neuroscience Research, Vol. 83, 845-856, 2006;

85. Flögel U., Niendorf T., Serkowa N., Brand A., Henke J., Leibfritz D. - Changes in Organic Solutes, Volume, Energy State, and Metabolism Associated with Osmotic Stress in a Glial Cell Line: A Multinuclear NMR Study, Neurochemical R., Vol. 20, Nr.7, 793-802, 1995;

86. Forsyth R.J. - Astrocytes and the Delivery of Glucose from Plasma to Neurons, Neurochem. Int., Vol. 28, Nr.3, 231-241, 1996; 
87. Frederksen C.M., Clausen J. - The Effects of Oxidative Stress in In Vitro Cultured Astroglial Cells, ATLA 27, 351-357, 1999;

88. Friede R.L. - The Enzymatic Response of Astrocytes to Various Ions In Vitro, The Journal of Cell Biology, Vol.20, 5-15, 1964;

89. Gallicchio V.S. - Lithium Enhanced Granulopoiesis and Megakaryocytopoiesis In Vitro: Potentiation with Agents that Accelerate Sodium Transport, LITHIUM, vol.1, 93-100, 1990;

90. Garcia-Perez J., Avila J., Diaz-Nido J. - Lithium Induces Morphological Differentiation of Mouse Neuroblastoma Cells, Journal of Neuroscience Research, Vol. 57, 261-270, 1999;

91. Giulian D., Vaca K., Corpuz M., - Brain Glia Release Factors with Opposing Actions upon Neuronal Survival, The Journal of neuroscince, Vol. 13(1), 29-37, 1993;

92. Gomes F.C.A., Paulin D., Neto V.M. (1999) Glial fibrillary acidic protein (GFAP): Modulation by growth factors and its implication in astrocytedifferentiation. Brazilian Journal of Medical and Biological Res. 32: 619-631.

93. Gorgos C. (1985) Vademecum în psihiatrie. Ed.Medicală. Bucureşti: 561-565.

94. Gottardi C.J., Gumbiner B.M. - Distinct molecular forms of $\beta$-catenin are targeted to adhesive or transcriptional complexes, The J. of Cell Biology, Vol.167,2, 339-349, 2004;

95. Gould T.D., Manji H.K. - In Vivo Evidence in the Brain for Lithium Inhibition of Glycogen Synthase Kinase-3, Neuropsychopharmacology, Vol. 29, 32-38, 2004;

96. Grafe P., Reddy M.M. (1983) Effects of lithium on electrical activity and potassium ion distribution in the vertebrate central nervous system. Brain Res. 279: 65-76.

97. Grunze H., Kasper S., Goodwin G., Bowden C., Baldwin D., Licht R., Vieta E., Moller H-J., WFSBP TASK FORCE ON Treatment Guidelines for BD - World Federation of Societies of Biological Psychiatry (WFSBP) Guidelines for Biological Treatment of BD, Part I: Treatment of Bipolar Depression, World J. Biol. Psychiatry, 3, 115-124, 2002;

98. Gu C., Casaccia-Bonnefil P., Srinivasan A., Chao M.V. - Oligodendrocyte Apoptosis Mediated by Caspase Activation, The Journal of Neuroscience, 19(8), 3043-3049, 1999;

99. Hansson E., Rönnbäck L. (1995) Astrocytes in glutamate neurotransmission. FASEB Journal 9: 343-350.

100. Hardy R., Raynolds R. (1991) Proliferation and differentiation potential of rat forbrain oligodendroglial progenitors both in vitro and in vivo. Dev. 111: 1061-1081.

101. Harwood A.J. - Lithium and bipolar mood disorder: the inositol-depletion hypothesis revisited, Molecular Psychiatry, Vol.10, 117-126, 2005;

102. Hăulică I. (1997) Fiziologia sistemului nervos. In: Fiziologia umană, Iled. Ed.Medicală. Bucureşti: 1011-1029.

103. Hăulică, I.- Fiziologie umană, Ediția a doua, Editura Medicală, Bucureşti, 2000;

104. Healy D. - The Latest Mania: Selling Bipolar Disorder, Plos Medicine, Vol.3, nr.4, 0441-0444, 2006;

105. Hedgepeth C.M., Conrad L.J., Zhang J., Huang H.C., Lee V.M., Klein P.S. (1997) Activation of the Wnt signaling pathway a molecular mechanism for lithium action. Developmental Biology 185, 82-91;

106. Hefco V. P.- Fiziologia animalelor şi a omului, Editura Did. şi Ped., Bucureşti, 1997;

107. Henderson J.C., Wolf C.R. (1992) Immunodetection of proteins by Western blotting. In Methods in molecular biology, vol.10: Immunochemicals protocols. Ed. by Manson M., The Humana Press, Inc., Totowa, NY: 221-233.

108. Henn F., Vollmayr B., Sartorius A. - Mechanisms of depression: the role of neurogenesis, Drug Discovery Today: disease Mechanisms, Vol.1, Nr.4, 407-411, 2004;

109. Hertz L., Dringen R., Schousboe A., Rominson R.S. (1999) Astrocytes: Glutamate producers for neurons. J. Neurosci. Res. 57: 417-428. 
110. Hetman M., Cavanaugh J.E., Kimelman D., Xia Z. - Role of Glycogen Synthase Kinase - $3 \beta$ in Neuronal Apoptosis Induced by Trophic Withdrawal, The Journal of Neuroscience, Vol. 20(7), 2567-2574, 2000;

111. Hongisto V., Smeds N., Brecht S., Herdegen T., Courtney M.J., Coffey E.T. - Lithium Blocks the c-Jun Stress Response and Protects Neurons via Its Action on Glycogen Synthase Kinase 3, Molecular and Cellular Biology, Vol.23, Nr.17, 6027-6037, 2003;

112. Hoslie E., Hoslie L. (1993) Receptors for neurotransmitters on astrocytes in the mammalian central nervous system. Progres in neurobiology 40: 477-506.

113. Htain W.W., Leong S.K., Ling E.A. (1995) A qualitative and quantitative study of the glial cells in normal and athimic mice. Glia 15: 11-21.

114. Ikonomov O.C., Manji H.K. - Molecular Mechanisms Underlying Mood Stabilization in ManicDepressive Illness: The Phenotype Challenge, American Journal of Psychiatry, Vol. 156, 15061514, 1999;

115. Iordăchescu D., Dumitru I.F. (1980) Biochimie practică. Bucureşti: 98-99.

116. Israil, Anca Mihaela - Biologie moleculară: prezent şi perspective, Editura Humanitas, Bucureşti, 2000;

117. Jakobsen S.N., Wilborg O. (1998) Selective effects of long-term lithium and carbamazepine administration on G-protein subunit expression on rat brain. Brain Res. 780: 46-55.

118. Jellinger K.A. - Cell death mechanisms in neurodegeneration, Journal of Cell and Molecular Medicine, Vol.5., Nr.1, 1-17, 2001;

119. Jope R.S. - Anti-bipolar therapy: mechanism of action of lithium, Molecular Psychiatry, Vol. 4, 117-128, 1999;

120. Jope R.S. (1999) A bimodal model of the mechanism of action of lithium. Mol. Psychiatry 4: 2125.

121. José Alberto Del Porto, Bipolar disorder: evolution of the concept and current controversies, REV. BRAS. PSIQUIATR, Vol. 26, 7-11, 2004;

122. Kahn D.A., Ross R., Printz D.J., Sachs G.S. - Treatment of Bipolar Disorder: A Guide for Patients and Families, A postgraduate medicine special report, 2000;

123. Kaplan I.H., Sadock I.B., Grebb A.I. Synopsis of Psychiatry, Williams and Wilkins, Baltmore, 8th Edition 1996.

124. Karp G. (1984) Cell biology, IInd ed., McGraw Hill Book Comp: 777-810.

125. Keck P.E. - The management of acute mania, BMJ., Vol. 327, 1002-1003, 2003;

126. Kelleher J.A., Chan P.H., Chan T.Y.Y., Gregory G.A. - Energy Metabolism in Hypoxic Astrocytes: Protective Mechanism of Fructose-1,6-Bisphosphate, Neurochemical Research, Vol.20, Nr.7, 785-792, 1995;

127. Kimelberg H.K. - Current Methods and Approaches to Studying Astrocytes: A forum Position Paper, NeuroToxicology, Vol. 20(5), 703-712, 1999;

128. Kimelberg H.K. (1983) Primary astrocyte cultures -A key to astrocyte function. Cell. Mol. Neurobiol. 3: 1-16.

129. Klein P.S., Melton D.A. (1996) A molecular mechanism for the effect of lithium on development. Proc. Natl. Acad. Sci. USA 93, 8455-8459;

130. Klerman G.L. The spectrum of mania. Compr. Psychiatry, 1981.

131. Knapp P.E., The Cell Cycle of Glial Cells Grown In Vitro: An Immunocytochemical Method of Analysis, The Journal of Histochemistry and Cytochemistry, Vol.40, Nr.9, 1992;

132. Kornyei Z., Czirok A., Vicsek T., Madarasz E. - Proliferative and Migratory Responses of Astrocytes to In Vitro Injury, Journal of Neuroscience Research, Vol. 61, 421-429, 2000;

133. Korr H., Siewert E., Strier U., Bertram C., Sensenbrenner M. - Characterization of astroglial cell proliferation in vitro and in vivo, Acta histochemica, 245-250, 1992; 
134. Koyama Y., Goldman E.J. (1999) Formation of GFAP cytoplasmic inclusions in astrocytes and their disaggregation by B-crystallin. Amer. J. Pathol. 154: 1563-1572.

135. Kraepelin E. Manic-depressive Insanity and Paranoia. Livingstone, Edinburg, 1921.

136. Laemmli U.K. (1979) Cleavage and structural proteins duting the assemby of the head of bacteriophage $\mathrm{T}_{4}$. Nature 227: 680-682.

137. Lakin-Thomas P.L. - Evidence against a direct role for inositol phosphate metabolism in the circadian oscillator and the blue-light signal transduction pathway in Neurospora crassa, Biochemical Journal, Vol. 292, p813-818, 1993;

138. Lee J.C., Mayer-Proschel M., Rao M.S. - Gliogenesis in the Central Nervous System, GLIA, Vol. 30, 105-121, 2000;

139. Lenox R.H. and Watson D.G (1994) - Lithium and the Brain: A Psychopharmacological Strategy to a molecular basis for manic depressive illness, Clin. Chem.40/2, 309-314

140. Lenox R.H., Frazer A., Mechanism of Action of Antidepressants and Mood Stabilizers, Neuropsychopharmacology: The Fifth Generation of Progress, Edited by Kenneth L.Davis et all, American College of Neuropsychopharmacology, Chapter 79, 1139-1163, 2002;

141. Lenox R.H., Gould T.D., Manji H.K. - Endophenotypes in Bipolar Disorder, American Journal of Medical Genetics (Neuropsychiatric Genetics), Vol. 114, 391-406, 2002;

142. Lenox R.H., Hahn C.G. (2000) Overview of the mechanism of action of lithium in the brain: Fifty-year update. J. Clin. Psichiatry 61, 5-15;

143. Lenox R.H., McNamara R.K. Papke R.L. Manji H.K. (1998) Neurobiology of lithium: An update. J.Clin. Psychiatry 59, 37-47;

144. Lenox R.H., Wang L. - Molecular basis of lithium action: integration of lithium-responsive signaling and gene expression networks, Molecular Psychiatry, Vol. 8, 135-144, 2003;

145. Leonhard K. The Classification of Endogenous Psychoses. Irvington, New York, 1979.

146. Levinson D.F., Umapathy C., Musthaq M. - Treatment of Schizoaffective Disorder and Schizophrenia with Mood Symptoms, Am. J. of Psychiatry, Vol. 156(8), 1138-1148, 1999;

147. Li V., Kelly K., Schrot R., Langan T.J. - Cell cycle kinetics and commitment in newborn, adult, and tumoral astrocytes, Developmental Brain Research, Vol. 96, 138-147, 1996;

148. Liesi P., Dahl D., Vaheri A. - Laminin is Produced by Early Rat Astrocytes in Primary Culture, The Journal of Cell Biology, Vol. 96, 920-924, 1983;

149. Lodish, Harvey \& colab. Molecular cell biology, Third Edition, Scientific American Books Inc., New York, 1995;

150. Longo K.A., Kennel J.A., Ochocinska M.J., Ross S.E., Wright W.S., MacDougald O.A. - Wnt Signaling Protects 3T3-L1 Preadipocytes from Apoptosis through Induction of Insulin-like Growth Factors, The Journal of Biological Chem., Vol. 277, Nr.41, 38239-38244, 2002;

151. LoPachin M.R.Jr., Aschner M. (1993) Glial-neuronal interaction: Relevance to neurotoxic mechanisms. Toxicology and applied pharmacology.118: 141-158.

152. Lubrich B., van Calker D., Peschka-Suss R. - Inhibition of inositol uptake in astrocytes by antisens oligonucleotides delivered by pH-sensitive liposomes, Eur. J. Biochem., Vol. 267, 24322438, 2000;

153. Luider T.M., Kros J.M., Sillevis Smith P.A.E., van den Bent M.J., Vecht C.J. (1999) Glial fibrillary acidic protein and its fragments discriminate astrocytoma from oligodendroglioma. Electrophoresis 20: 1087-1091.

154. Luskin M.B., Parnavelas J.G., Barfield J.A. (1993) Neurons, astrocytes and oligodendrocytes of the rat cerebral cortex originate from separate progenitor cells: An ultrastructural analysis of clonally related cells. J. Neurosci. 13: 1730-1750.

155. Madrenas, Joakin; Schwartz, Ronald H.; Germain, Ronald N. - Interleukin 2 production, not the pattern of early T-cell antigen receptor- dependent tyrosine phosphorylation, controls anergy 
induction by both agonists and partial agonists; Proc. Natl. Acad. Sci. USA, Vol. 95, p:97369741, 1996;

156. Maj M., Pirozzi R., Magliano L., Bartoli L. (1998) - Long-term outcome of lithium prophylaxis in bipolar disorder: A 5-Year prospective study of 402 patients at a Lithium Clinic. Am J. Psychyatry 155/1, 30-35

157. Manji H.C., Potter W.Z., Lenox R.H. (1995) Signal transduction pathways. Molecular targets for lithium's actions. Arch. Gen. Psychiat. 52: 531-543.

158. Manji H.K., Drevets W.C., Charney D.S. - The cellular neurobiology of depression, Nature Medicine, Vol.7, Nr.5, 541-547, 2001;

159. Manji H.K., Moore G.J., Chen G. - Bipolar disorder: leads from the molecular and cellular mechanisms of action of mood stabilisers, British Journal of Psychiatry, 178, 107-119, 2001;

160. Manji H.K., Moore G.J., Chen G. - Lithium Up-Regulates the Cytoprotective Protein Bcl-2 in the CNS In Vivo: A role for Neurotrophic and Neuroprotective Effects in Manic Depressive Illness, Journal of Clinical Psychiatry, Vol.61, 82-95, 2000;

161. Manji H.K., Quiroz J.A., Payne J.L., Singh J., Lopes B.P., Viegas J.S., Zarate C.A. - The underlying neurobiology of bipolar disorder, World Psych., Vol. 2, Nr.3, 136-146, 2003;

162. Mao C.D., Hoang P., DiCorleto P.E. - Lithium Inhibits Cell Cycle Progression and Induces Stabilization of p53 in Bovine Aortic Endothelial Cells, The Journal of Biological Chemistry; Vol.276, nr.28, 26180-26188, 2001;

163. Markowitz G.S., Radhakrishhnan J., Kambham N., Valeri A.M., Hines W.H., D’Agati D.V. (2000) Lithium neurotoxicity: a progressive combined glomerular and tubulointerstitial nephropathy. J. Am. Soc. Nephrol. 11, 1439-1448;

164. Marneros A., Angst J. Bipolar Disorders: 100Years after Manic Depressive Insanity Kluwer, Dordrecht, 2000.

165. Masemola A. M., Becker R.W., Tyobeka E.M. - The effects of lithium on the growth and phorbol ester (TPA) induced differentiation of two HL-60 sublines. Pag.727-732,1991

166. Massot O., Rousselle J-C., Fillion M-P., Januel D., Plantefol M., Fillon G. - 5HT1B Receptors: A Novel Target for Lithium, Possible Involvement in Mood Disorders, Neuropsychopharmacology, Vol.21, nr.4, 530-541, 1999;

167. Matthopoulos D.P., Tzaphlidou M., Leontiou I. (1995) Morphological alterations caused by lithium in various cell lines. Cell Biol. InteARNt. 19: 499-506.

168. Mattson M.P., Bruce A.J., Blanc E.M.- Elusive roles for astrocytes in neurodegenerative disorders, Neurobiology of Aging, Vol. 17, Nr.3, 485-487, 1996;

169. May M., Akiskal H.S., Lopez-Ibor J.J., Sartorius N. Bipolar Disorder WPA Series Evidence and Experience in Psychiatry, vol. 5, John Wiley and Sons Ltd, 2002.

170. McCarthy K., DeVellis J. (1980) Preparation of separate astroglial and oligodendroglial cell cultures from rat cerebral tissue. J Cell Biol.85: 890-902.

171. McEwen B.S., Olié J.P. - Neurobiology of mood, anxiety, and emotions as revealed by studies of a unuque antidepressant:tianeptine, Molecular Psychiatry, Vol.10, 525-537, 2005;

172. McGarth B.M. - Towards a Comprehensive Understanding of Bipolar Disorder: In Vivo MRS Investigation of the Phosphatidilinositol Cycle, MJM, Vol.8, 40-49, 2004;

173. Mead C., Pentreath V.W. (1998) Evaluation of toxicity indicators in rat primary astrocytes, $\mathrm{C}_{6}$ glioma and human 1321N1 astrocytoma cells: Can gliotoxicity be distinguished from cytotoxicity ? Arch Toxicol 72: 372-380.

174. Meltzer E., Steinlauf S. - The clinical manifestations of Lithium intoxication, IMAJ, Vol.4, 265267, 2002;

175. Messiha F.S. (1993) Maternally - mediated developmental lithium toxicity in the mouse. Gen. Pharmac. 24, 9-15; 
176. Michelon L., Vallada H. - Genetics of bipolar disorder, Rev Bras. Psiq., Vol. 26 (III), 2004;

177. Miller R.H., Ono K. (1998) Morphological analysis of the early stages of oligodendrocytes development in the vertebrate central nervous system. Microsc. Res. Tech. 41: 441-453.

178. Minami Y., Horikawa K., Akiyama M., Shibata S. - Restricted feeding induces daily expression of clock genes and Pai-1 mRNA in the heart of Clock mutant mice, FEBS Letters, Vol.526, 115118, 2002;

179. Mitchell P.B., Malhi G.S., Ball J.R. - Major advances in bipolar disorder, MJA, Vol.181, Nr.4, 207-210, 2004;

180. Mitchell P.B., Slade T., Andrews G. - Twelve-month prevalence and disability of DSM-IV bipolar disorder in an Australian general population survey, Psychological Medicine, Vol.34, 777-785, 2004;

181. Monks P.J, Thompson J.M., Bullmore E.T., Suckling J., Brammer M.J., Williams S.C.R., Simmons A., Giles N., Lloyd J., Harrison C.L., Seal M., Murray R.M., Ferrier I.N., Young A.H., Curtis V.A. - A functional MRI study of working memory task in euthymic bipolar disorder: evidence for task-specific dysfunction, Bipolar Disorder, Vol.6, 550-564, Blackwell Munksgaard, 2004;

182. Montgomery D.L. (1994) Astrocytes: Form, functions and roles in disease. Vet Pathol. 31: 145167.

183. Mora A., Gonzalez-Polo R.A., Fuentes J.M., Soler G., Centeno F. - Different mechanisms of protection against apoptosis by valproate and $\mathrm{Li}^{+}$, Eur. J. Biochem., 266, 886-891, 1999;

184. Munsch T., Deitmer J.W. - Sodium-bicarbonate cotransport current in identified leech glial cells, Journal of Physiology, Vol.474.1, 43-53, 1994;

185. Murphy S. - Production of Nitric Oxide by Glial Cells: Regulation and Potential Roles in the CNS, GLIA, Vol.29, 1-14, 2000;

186. Nagaraja T.N, Brookes N.- Glutamine Transport in Mouse Cerebral Astrocytes, J.of Neurochemistry, 66, 1665-1674, 1996;

187. Nonaka S., Hough C., Chuang D.M. (1998) Chronic lithium treatment robustly protect neurons in the central nervous system against excitotoxicity by inhibiting N-methyl-D-aspartate receptormediated calcium influx. Proc. Natl. Acad. Sci. USA 95: 2642-2647.

188. Oakley p.W., Dawson A.H., White I.M. (2000) Lithium: Thyroid effects and altered renal handling. Clinical Toxicology 38, 333-337;

189. Olinic A., Toader R.M., Murețan V.D., Mărgineanu M., Neagoe A., Coca M. Murețan. (1992) Curs de histologie, vol.I. Litografia UMF Cluj-Napoca.

190. Ormerod G.M. (1992) Enzyme-antienzyme method for immunohistochemistry. In: Methods in molecular biology, vol.10: Immunochemical protocols. Ed. by Manson M., The Humana Press, Inc. Totowa, NY: 117-125.

191. Ouznadij H., Wiscocq J.C., Martini F., Thellier M. (1999) Lithium accumulation in the blood plasma of Li-treated pregnant mice. Lithium -50 years: recent advences in biology and medicine, 5-11;

192. Pass D. And Freeth G. (1993) - The rat. ANZCCART News, Vol6/4, 1-4

193. Pekny M., Johansson C.B., Eliasson C., Stakeberg J., Wallén A., Perlmann T., Lendahl U., Betsholtz C., Berthold C., Friesen J - Abnormal Reaction to CNS Injury in Mice Lacking GFAP and Vimentin, The Journal of Cell Biology, Vol. 145, Nr.3, 503-514, 1999;

194. Perris C. A study of bipolar (manic-depressive) and unipolar recurrent depresive psychoses. Acta psychiat. scand., 1966, Suppl. 194.

195. Pesce A.J. (1989) Lactat dehydrogenase. In: Clinical chemistry. Ed. by Kaplan L.A.,Pesce A.J. The C.V.Mosby Comp.: 924-928. 
196. Phiel C.J., Klein P. (2001) Molecular targets of lithium action. Annu. Rev Pharmacol. Toxicol. 41, 789-813;

197. Phiel C.J., Wilson C.A., Lee V. M.-Y., Klein P.S. - GSK-3 $\alpha$ regulates production of Alzheimer's disease amyloid- $\beta$ peptides, Nature, Vol.423, 435-439, 2003;

198. Picchini A.M., Manji H.K., Gould T.D. - GSK-3 and neurotrophic signaling: novel targets underlying the pathophysiology and treatment of mood disorders, Elsevier Drug Discovery, Vol.1, nr.4, 419-428, 2004;

199. Pinkas-Kramarski R., Eilam R., Spiegler O., Lavi S., Liu N., Chang D., Wen D., Schwartz M., Yarden Y. (1994) Brain neurons and glial cells express Neu differetiation factor/ heregulin: A survival factor for astrocytes. Proc. Natl. Acad. Sci. USA 21: 9387-9391.

200. Plenge P.(1982 - Animal models and lithium treatment. Lithium: Inorganic Pharmacology and Psychiatric Use, Edited by Nicholas J. Birch, IRL Press Lim. Oxford, England, 317-318

201. Popescu O. (1990) Electroforeza proteinelor în geluri de poliacrilamidă. Ed. Tehnică.

202. Prieto M., Alonso G. (1999) Differential sensitivity of cultured tanycytes and astrocytes to hydrogen peroxide toxicity. Exp. Neurol. 155: 118-127.

203. Prosser R.A., Edgar D.M., Heller H.C., Miller J.D. (1994) A possible glial role in the mammalian circadian clock. Brain Res. 643: 296-301.

204. Quiroz J.A., Singh J., Gould T.D., Denicoff K.D., Zarate C.A, Manji H.K. - Emerging experimental therapeutics for bipolar disorder: clues from the molecularpathophysiology, Molecular Psychiatry, Vol.9, 756-776, 2004;

205. Ramakrishnan S.N., Muscat G.E.O. - The orphan Rev-erb nuclear receptors: a link between metabolism, circadian rhythm and inflammation, NRS, Vol.4., 1-5, 2006;

206. Reiche, F.V.; Silva, F.L.V; Kaminami, M.S. - Immune and normal activity in adults suffering from depression, Brazilian JouARNl of Medical and Biological Research, 35:581-587, 2002;

207. Reiser G., Duhm J. (1982) Pathways for transport of lithium ions in neuroblastoma $x$ glioma hybrid cells at „therapeutic” concentrations of Li. Brain Res. 252: 247-258.

208. Ren-Wu Chen and De-Maw Chuang, Long Term Lithium Treatment Suppresses p53 and Bax Expression but Increases Bcl-2 Expression, The Journal of Biological Chemistry, Vol. 274, Nr. 10, 6039-6042, 1999;

209. Rice A.M., Sartorelli A.C. - Inhibition of 20 S and 26S Proteosome Activity by Lithium Chloride, The Journal of Biological Chemistry, Vol. 276, Nr.46, 42722-42727, 2001;

210. Richardson A., Hao C., Federoff S. (1993) Microglia progenitor cells: A subpopulation in cultures of mouse neopallial astroglia. Glia 7: 25-33.

211. Rintala J., Seemann R., Chandrasekaran K., Rosenberger A.T., Chang L., Contreras A.M., Rapoport S.I., Chang C.J.M. (1999) $85 \mathrm{kDa}$ cytosolic phospholipase A2 is a target for chronic lithium in rat brain. NeuroReport 10: 3887-3890.

212. Russo T., Mogavero A.R., Ammerdola R. (1993) Immortalization of a cell line showing some characteristics of the oligodendrocyte phenotype. Neurosci Lett. 159: 159-162.

213. Rutka J.T., Ackerley C., Hubbard S.L., Tilup A., Dirks P.B.,Jung S., Ivanchuk S., Kurimoto M., Tsugu A., Becker L.E. (1998) Characterization of glial filaments-cytoskeletal interactions in human astrocytomas: An immunoultrastructural analysis. Eur. J. Cell. Biol. 76: 279-287.

214. Rutka J.T., Murakami M., Dirks P.B., Hubbard S.L., Becker L.E.,Fukuyama K., Jung S., Tsugu A., Matsuzawa K. (1997) Role of glial filaments in cell and tumors of glial origin : A review. J.Neurosurg. 87: 420-430.

215. Ryves J., Harwood A.J.-Lithium Inhibits GSK-3 by Competition for Mg, BBRC, 280, 2001;

216. Salinovich O., Montelaro R.C. (1986) Reversible staining and peptide mapping of proteins transferred to nitrocelulose after separation by sodium dodecyl sulfate- poliacrilamide gel electrophoresis. Anal. Biochem.156: 341-347. 
217. Schimmer B.P. (1971) Effects of catecholamines and monovalent cationson adenilate cyclase activity in cultured glial tumor cells. Biochem. Biophys. Acta 252: 567-573.

218. Schimmer B.P. (1973) Influence of lithium on epinephrine -stimulated adenylate cyclase activity in cultured glial tumor cells. Biochem. Biophys. Acta 327: 186-192.

219. Schnitzer J., Franke W.W., Schachner M., Immunocytochemical Demonstration of Vimentin in Astrocytes and Ependymal Cells of Developing and Adult Mouse Nervous System, The Journal of Cell Biology, Vol. 90, 435-447, 1981;

220. Schou M. (1998) Treating recurrent affective disorders during and after pregnancy. Drug safty 18, 143-152;

221. Schou M. (2001) Lithium treatment at 52 Journal of affective disorders 67, 21-32

222. Schrauzer G.N. - Lithium: Occurrence, Dietary Intakes, Nutritional Essentiality, Journal of American College of Nutrition, Vol.21, Nr.1, 14-21, 2002;

223. Seres-Sturm L. (1993) Neuroanatomie. Ed.Didactică şi Pedagogică Bucureşti.

224. Sharp, J.A; Burwell, R.G. - Interaction (,peripolesis”) of macrophages and lymphocytes after skin homografting or challenge with soluble antigens, Nature, 188:474, 1960;

225. Shears S.B. (1988) Lithium and inositol lipid turnover. In: Lithium: Inorganic pharmacology and psychiatric use. Ed.by Birch N.J. IRL Press Ltd: 201-205.

226. Sheffield J.B., Graff D., Li H.P. (1987) A solid-phase method for the quantitation of protein in the presence of sodium dodecyl sulfate and other interfering substances. Anal. Biochem. 166: 4954.

227. Siegel, R. - The morphology of the thymus and their relation to leukemia. In: Good RA, ed. The thymus in immunobiology. New York: Harper \& Row, 1964;

228. Silva G.A., Feeney C., Milles L.R., Theriault E. - A novel and rapid method for culturing pure rat spinal cord astrocytes on untreated glass, J. of Neuroscience Meth., 80, 1998;

229. Singh T.D., Shanker R. (1998) Lithium regulation of protein phosphorylation in rat cerebral cortex slices in vitro. Biochem. Mol. Biol. InteARNt. 44: 497-505.

230. Skoff R.P., Knapp P.E. (1991) Division of astroblasts and oligodendroblasts in postnatal rodent brain: Evidence for separate astrocyte and oligodendrocyte lineages. Glia 4: 165-174.

231. Snyder Jessica - Liénard Oscillator Modeling of Bipolar Disorder, 2003;

232. Stăncioiu, Nicolae - Fiziologia animală, Editura Coral Sanivet, Bucureşti, 1999;

233. Stein, Wilfred D. - Canale, transportori şi pompe, o introducere în transportul membranar, Editura Universității bucureşti, 1997;

234. Strunecka A., Patocka J., Sarek M. - How does lithium mediate its therapeutic effects?, Journal of Applied Medicine, Vol.3, 25-35, 2005;

235. Subhash M.N., Vinod K.Y., Srinivas B.N. - Differential effect of lithium on 5-HT ${ }_{1}$ receptorlinked system in regions of rat brain, Neurochem. Int., Elsevier, vol.35, 337-343, 1999;

236. Sun X., Young L.T., Wang J.F., Grof P., Turecki G., Rouleau G.A., Alda M. - Identification of Lithium-Regulated Genes in Cultured Lymphoblasts of Lithium Responsive Subjects with Bipolar Disorder, Neuropsychopharmacology, Vol.29, 799-804, 2004;

237. Symonds LL and Jeste DV: Late-onset schizophrenia. In: Late-Onset Mental Disorders A. Marneros (ed.), American Psychiatric, Press Washington D.C. 83-97, 1999.

238. Tiffany-Castiglioni E. (1993) Cell culture models for lead toxicity in neuronal and glial cells. Neurotoxicology 14: 513-536.

239. Tiffany-Castiglioni E. (1998) Astroglia in metal metabolism and toxicity: Commentary on forum position paper. Neurotoxicology 19: 19-22.

240. Timmer R.T., Sands J.M. (1999) Lithium intoxication, J. Am. Soc. Nephrol 10, 666-674;

241. Timson J. Price D.J. (1971) Lithium and mitosis, The Lancet 93; 
242. Toback F.G. (1980) Induction of growth in kidney epithelial cells in culture by $\mathrm{Na}^{+}$. Proc. Natl. Acad. Sci. USA 77: 6654-6656.

243. Tondo L., Baldessarini R.J., Hennen J.- Lithium and Suicide Risk in Bipolar D., AFSP, 2005;

244. Towbin H., Staehelin T., Gordon J. (1979) Electrophoretic transfer of proteins from polyacrylamide gels to nitrocellulose sheets: Procedure and some applications. Proc. Natl. Acad. Sci. USA 76: 4350-4354.

245. Tzaphlidou M. - Role of the collagen fibrile positive staining pattern in determining lithium side effects on collagen, Lithium-50 Years, 75-80, 1999;

246. Uluitu M. (1991) The action of lithium, water and serotonin in blood. In: Lithium Therapy Monographs vol.4. Ed. by Johnson F.N., Lancaster: 121-145.

247. Unger J.W. Glial reaction in aging and Alzheimer's disease. Microsc.Res.T. 43: 24-28, 1998

248. Van Noorden S- Tissue preparation and immunostaining for light microscopy. In: Immunocytochemistry. Ed.by Polack J.M., Van Noorden S. Wright and Sons Ltd.26-53 . 1986

249. Vincent V.A.M., Tilders F.J.H., Van Dam A.M. (1998) Production, regulation and role of nitric oxide in glial cells. Mediators of Inflammation 7: 239-255.

250. Von Visger J.R., Yeon D.S., Markelonis G. Differentiation and maturation of astrocytes derived from neuroepithelial progenitor cells in culture. Exp Neurol. 128: 34-40, 1994

251. Wang L., Liu X., Lenox R.H.- Transcriptional down-regulation of MARCKS gene expression in immortalized hippocampal cells by lithium, J. of Neurochem., 79, 2001;

252. Weidinger G., Moon R.T. - When Wnts antagonize Wnts, The J.of Cell Biology, 162, 2003;

253. Williams K., Amit Bar-Or M.S., Elling Ulvestad B.S., Olivier A, Antel J.P.,Yong V.W. (1992) Biology of adult human microglia in culture: Comparisons with peripheral blood monocytes and astrocytes. J. Neuropath. Exp. Neurol. 51: 538-549.

254. Williams R., Ryves W.J., Dalton E.C., Eickholt B., Shaltiel G., Harwood A.J. - A molecular cell biology of lithium, Bichemical Society, 799-802, 2004;

255. Williams R.S.B., Harwood A.J.-Lithium therapy and signal transduction, TiPS, 21, 2000;

256. Worley P.F, Heller W.A., Snyder S.H., Baraban J.M. - Lithium Blocks a PhosphoinositideMediated Cholinergic Respone in Hippocampal Slices, Science, Vol 239, 1988;

257. Yuan P., Chen G., Manji H.K. - Lithium Activates the c-Jun $\mathrm{NH}_{2}-$ Terminal Kinases In Vitro and in the CNS In Vivo, Journal of Neurochemistry, Vol.73, 2299-2309, 1999;

258. Zajicek J.P., Wing M., Scolding N.J., Compston D.A.S. (1992) Interaction between oligodendrocytes and microglia: A major role for complement and tumour necrosis factor in oligodendrocytes adherence and killing. Brain 115(part VI): 1611-1633.

259. Zamfirecu Gabriela, Meşter Radu - Celulele gliale - componente esențiale ale sistemului nervos, Editura Academiei Române, Studii şi cercetări de BIOLOGIE, Seria Biologie Animală, Tomul 50, nr.1, p.65-74, Bucureşti, 1998; 

Litiul stârneşte un deosebit interes ştiințific pentru cã, deşi are o structurã atât de simplã, o chimie uşor de analizat şi proprietãți fizice bine stabilite, pleiada de efecte asupra sistemelor biologice prin influențarea numeroaselor procese celulare şi moleculare şi mecanismul sãu de acțiune încã neelucidat generează un mister pe care ştiința modernă încearcă să îl descifreze.

Sãrurile de litiu şi-au dovedit eficiența în tratamentul tulburãrii bipolare, formal cunoscutã ca boala maniaco-depresivã. Aşa cum o aratã şi numele, persoanele care suferã de tulburare bipolarã traverseazã schimbãri afective severe, de la fericire maximã la o depresie extremã. Între 0.4 şi $1.6 \%$ din populație suferã de aceastã condiție psihiatricã.

Utilizarea litiului în medicinã cunoşte un semnificativ succes în câmpul farmacologiei inorganice şi prezintã un interes particular, de vreme ce litiul este cel mai uşor element solid a cãrui chimie este relativ simplã. Se acceptã cã orice ar determina litiul la nivel celular, acțiunea lui are drept țintã procese fundamentale din viața celularã.

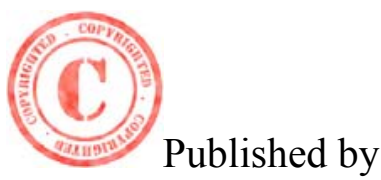

Editura Balnearã - http://editura.pluto.ro

Laborator Culturi Celulare - http://cell-culture.xhost.ro/

E-mail: culturi@gmail.com

B-dul Ion Mihalache, 11A, Sector 1, Bucharest, Romania ISBN: 978-606-92826-0-1 